\title{
Country Reports on Terrorism 2019
}

BUREAU OF COUNTERTERRORISM

Country Reports on Terrorism 2019 is submitted in compliance with Title 22 of the United States Code, Section 2656f (the "Act"), which requires the Department of State to provide to Congress a full and complete annual report on terrorism for those countries and groups meeting the criteria of the Act. 
Foreword

Table of Contents

Glossary

For More Information

Chapter 1-Country Reports on Terrorism Africa

East Asia and the Pacific

Europe

The Middle East and North Africa

South and Central Asia

Western Hemisphere

Chapter 2-State Sponsors of Terrorism

Chapter 3-The Global Challenge of Chemical, Biological, Radiological, or Nuclear Terrorism

Chapter 4-Terrorist Safe Havens (Update to 7120 Report)

Chapter 5-Foreign Terrorist Organizations

Chapter 6-Legislative Requirements and Key Terms

Appendix B-Terrorism Deaths, Injuries, and Kidnappings of U.S. Citizens 


\section{Country Reports on Terrorism Foreword}

In 2019, the United States and our partners made major strides to defeat and degrade international terrorist organizations. Along with the Global Coalition to Defeat ISIS, in March, the United States completed the destruction of the so-called "caliphate" in Iraq and Syria. In October, the United States launched a military operation that resulted in the death of Abu Bakr al-Baghdadi, the self-proclaimed "caliph" of ISIS. As part of the maximum pressure campaign against the Iranian regime - the world's worst state sponsor of terrorism - the United States and our partners imposed new sanctions on Tehran and its proxies. In April, the United States designated Iran's Islamic Revolutionary Guard Corps (IRGC), including its Qods Force, as a Foreign Terrorist Organization (FTO) - the first time such a designation has been applied to part of another government. And throughout the year, a number of countries in Western Europe and South America joined the United States in designating Iran-backed Hizballah as a terrorist group in its entirety.

Despite these successes, dangerous terrorist threats persisted around the world. Even as ISIS lost its leader and territory, the group adapted to continue the fight from its affiliates across the globe and by inspiring followers to commit attacks. In Africa, ISIS formally recognized a number of new branches and networks in 2019, and ISIS-affiliated groups were active across the continent, including in the Sahel, the Lake Chad region, and East Africa. In South and Southeast Asia, ISIS affiliates carried out attacks and inspired others to do so as well. The ISIS-inspired attacks in Sri Lanka on Easter Sunday killed more than 250 innocent victims, including five U.S. citizens, representing one of ISIS's deadliest attacks ever.

The Iranian regime and its proxies continued to plot and commit terrorist attacks on a global scale. In the past, Tehran has spent as much as $\$ 700$ million per year to support terrorist groups, including Hizballah and Hamas, though its ability to provide financial support in 2019 was constrained by crippling U.S. sanctions. The regime was directly involved in plotting terrorism through its IRGC and Ministry of Intelligence and Security, including plots in recent years in North and South America, Europe, the Middle East, Asia, and Africa. Tehran also continued to permit an al-Qa'ida (AQ) facilitation network to operate in Iran, sending money and fighters to conflict zones in Afghanistan and Syria, and it still allowed AQ members to reside in the country. Finally, the Iranian regime continued to foment violence, both directly and through proxies, in Bahrain, Iraq, Lebanon, Syria, and Yemen.

In 2019, the United States and its partners pursued AQ around the world. The organization faced a significant setback with the elimination of Hamza bin Laden, Usama bin Laden's son and a rising AQ leader. Yet the group and its associated forces remained resilient and continued to pose a threat in Africa, the Middle East, and elsewhere. Al Shabaab in the Horn of Africa, Jama'at Nasr al-Islam wal Muslimin in the Sahel, and Hay'at Tahrir al-Sham/Al-Nusrah Front in Syria are among the world's most active and dangerous terrorist groups. In December, a member of the Royal Saudi Air Force opened fire at Naval Air Station Pensacola in Florida, where he was receiving training, killing three people and wounding eight. Before the shooting, the gunman had coordinated with al-Qa'ida in the Arabian Peninsula (AQAP), which claimed credit for the attack. Today, AQ's network continues to exploit under-governed spaces, conflict zones, and global security gaps to recruit, fundraise, and plot attacks. 
The threat posed by racially or ethnically motivated terrorism (REMT), particularly white supremacist terrorism, remained a serious challenge for the global community. Continuing a trend that began in 2015, there were numerous deadly REMT attacks around the world in 2019, including in Christchurch, New Zealand; Halle, Germany; and El Paso, Texas.

Amid this diverse and dynamic threat landscape, the United States continued its longstanding role as the world's counterterrorism leader, taking decisive action to combat these threats and rallying its allies and partners to contribute to the fight.

In September, President Trump issued Executive Order 13886, enabling the Departments of State and the Treasury to more effectively sanction the leaders of terrorist organizations and those who participate in terrorist training. This was the most significant update of the federal government's terrorist designation authorities since the aftermath of the 9/11 attacks. In May, the United States led a successful campaign at the UN Security Council's 1267 Sanctions Committee to designate ISIS-Khorasan, the first ISIS affiliate ever listed at the UN.

In another historic action, the U.S. Department of State designated Iran's IRGC as an FTO in April 2019. This unprecedented step reflected the Iranian regime's unique place among the governments of the world in its use of terrorism as a central tool of its statecraft. In response to a wave of Iranian terrorist plots in Europe in 2018, the United States launched the Countering Transnational Terrorism Forum (CTTF) in 2019. The CTTF brought together law enforcement officials, prosecutors, and financial practitioners from more than 25 countries to disrupt Iranian terrorist activities and networks.

The United States also continued to spearhead high-level diplomatic engagement on Hizballah - an Iran-backed terrorist group that is based in Lebanon but that has a truly global reach. Throughout the year, the United States ratcheted up efforts to degrade and disrupt Hizballah's finances, with numerous designations of financial entities, facilitators, and money launderers tied to the group. In July, the United States and Argentina co-hosted the second Western Hemisphere Counterterrorism Ministerial, which commemorated the 25th anniversary of Hizballah's attack on a Jewish cultural center in Buenos Aires. This engagement yielded concrete results. In 2019, Argentina, Kosovo, Paraguay, and the United Kingdom all joined the United States in designating the entirety of Hizballah as a terrorist organization, rejecting the false distinction between its "military wing" and a purportedly "political wing."

Another major line of effort for 2019 was the repatriation, prosecution, and rehabilitation of ISIS fighters and family members to prevent them from ever returning to the battlefield. Since 2011, more than 40,000 foreign terrorist fighters (FTFs) from nearly a hundred countries swarmed into Syria and Iraq, and about 2,000 of these FTFs were captured and detained by the Syrian Democratic Forces (SDF). The United States has led by example, bringing back our citizens and prosecuting them where appropriate. As of December 2019, the United States repatriated a total of 23 U.S. citizens from Syria and Iraq - eight adults and 15 children - and the Department of Justice charged six of the adults with a variety of terrorism-related crimes. Those numbers include 15 U.S. citizens repatriated in 2019 (five adults and 10 children; three of the adults have been charged by the Justice Department). 
The United States continued to call on other countries to follow our example and repatriate their own citizens, and we assisted a number of partners in doing so. The State Department deployed technical experts to Jordan, Kazakhstan, Kosovo, Kyrgyzstan, the Maldives, North Macedonia, and Trinidad and Tobago to help develop effective protocols and programs for the rehabilitation and reintegration of FTF family members. Working closely with the Departments of Justice and Defense, the State Department also mobilized the international community to more effectively use battlefield evidence in criminal investigations and prosecutions, including training partner countries on how to collect, store, and transfer battlefield evidence. This has enabled the United States to more readily share battlefield evidence with our foreign partners. Other governments and institutions - including NATO, INTERPOL, and the UN - are now taking steps to improve their own efforts as well.

The United States also played a major role in building our partners' capabilities to detect, disrupt, and dismantle terrorist networks. Our goal was to enable governments on the front lines to address the terrorist threats they face on their own, without needing to rely on the United States in the future. Key lines of effort included information sharing, aviation and border security, countering terrorist radicalization and recruitment, crisis response capability, countering terrorism finance, repatriating FTFs, countering Iran-backed terrorist groups, and law enforcement "finishes" - arresting, prosecuting and incarcerating terrorists.

The United States also leveraged multilateral organizations to advance key U.S. counterterrorism priorities. In September, the 30-member Global Counterterrorism Forum (GCTF) adopted a new series of good practices to assist countries in meeting their watchlisting and screening obligations under UN Security Council Resolution 2396, a landmark resolution spearheaded by the United States in 2017. The GCTF developed and adopted new guiding principles - and accompanying policy, legal, and technical tools - to counter terrorist use of unmanned aerial systems against civilian targets. Together with Chile, the United States launched the Inter-American Network on Counterterrorism through the Organization for American States' Inter-American Committee on Terrorism (OAS/CICTE). This network will enable participating OAS members to share information on a $24 / 7$ basis to respond more effectively to terrorist threats.

The United States engaged a host of international partners - from governments to local religious leaders to tech companies - to counter terrorist radicalization and recruitment, both online and offline, and to help develop messaging strategies and counter disinformation and propaganda. We supported international initiatives, including the Strong Cities Network, which trained more than 200 municipal leaders from dozens of cities through multiple workshops and exchanges. Approximately 20 cities adopted new policies and practices to counter terrorist radicalization, including the forming of the Task Force Against Hate, to specifically counter REMT.

These efforts are only a snapshot of our ongoing work to protect the United States and our allies from the scourge of terrorism. Country Reports on Terrorism 2019 provides a detailed review of last year's successes and the ongoing challenges facing our country and our partners. As we look to 2020 and beyond, the United States and our partners remain deeply committed to the global counterterrorism fight.

Ambassador Nathan A. Sales

Coordinator for Counterterrorism 


\section{GLOSSARY OF ABBREVIATIONS}

AMISOM African Union Mission in Somalia

AML/CFT Anti-Money Laundering and Countering Financing of Terrorism

APEC Asia Pacific Economic Cooperation

APG Asia/Pacific Group on Money Laundering

API Advance Passenger Information

ASEAN Association of Southeast Asian Nations

ATS-G Automated Targeting System-Global

ATA Anti-Terrorism Assistance

AU African Union

CFT Countering the Financing of Terrorism

CT Counterterrorism

CTED United Nations Security Council Counter-Terrorism Committee Executive Directorate

CBP U.S. Customs and Border Protection

CVE Countering Violent Extremism

DHS U.S. Department of Homeland Security

DoD Department of Defense

DOJ U.S. Department of Justice

EAG Eurasian Group on Combatting Money Laundering and Terrorist Financing

EU European Union

EUROPOL European Union Agency for Law Enforcement Cooperation

EXBS Export Control and Related Border Security Program

FATF Financial Action Task Force

FIU Financial Intelligence Unit

FTO Foreign Terrorist Organization

FTF Foreign Terrorist Fighter

GAFILAT Financial Action Task Force of Latin America

GCERF Global Community Engagement and Resilience Fund

GCTF Global Counterterrorism Forum

GICNT Global Initiative to Combat Nuclear Terrorism

GTR Global Threat Reduction Program

ICAO International Civil Aviation Organization

IAEA International Atomic Energy Agency

IED Improvised Explosive Device

INTERPOL International Police Criminal Organization

ISIS Islamic State of Iraq and Syria

JNIM Jama-at Nusrat al-Islam wal Muslim

MINUSMA UN Multidimensional Integrated Stabilization Mission in Mali

MONEYVAL Committee of Experts on the Evaluation of Anti-Money Laundering

MOU Memorandum of Understanding

MFT Measures and the Financing of Terrorism

NATO North Atlantic Treaty Organization

NGO Nongovernmental Organization

ODNI Office of the Director of National Intelligence

OPCW Organization for the Prohibition of Chemical Weapons 
OSCE Organization for Security and Co-operation in Europe

PKK Kurdistan Workers' Party

PNR Passenger Name Record

PREACT Partnership for Regional East Africa Counterterrorism

PISCES Personal Identification Secure Comparison and Evaluation System

REMT Racially and Ethnically Motivated Terrorism

TSCTP Trans-Sahara Counterterrorism Partnership

VBIED Vehicle-Borne Improvised Explosive Device

UN United Nations

UNDP United Nations Development Programme

UNOCT United Nations Office of Counter-Terrorism

UNODC United Nations Office on Drugs and Crime

UNSC United Nations Security Council

UNSCR United Nations Security Council Resolution

USAID United States Agency for International Development

WMD Weapons of Mass Destruction

\section{For More Information}

\section{The Human Rights Report}

In the countries listed below, significant human rights issues influenced the state of terrorist activity in the country and may have impeded effective counterterrorism policies and programs or supported causes and conditions for further violence. Such human rights issues included, among others: unlawful and arbitrary killings, including extrajudicial killings, forced disappearances, torture, and arbitrary detention (all of the preceding by both government and nonstate actors); harsh and life-threatening prison conditions; violence against and unjustified arrests of journalists; substantial interference with the rights of peaceful assembly and freedom of association; widespread and pervasive corruption; repression of religious freedom ad violence against religious minorities; and forced and bonded labor.

Please see the U.S. Department of State 2019 Country Reports on Human Rights Practices and the 2019 International Religious Freedom Reports for more information:

Afghanistan, Algeria, Bahrain, Bangladesh, Egypt, India, Iraq, Iran, Kazakhstan, Kenya, Kyrgyz Republic, Lebanon, Libya, Maldives, Pakistan, Russia, Saudi Arabia, Sri Lanka, Syria, Tajikistan, Turkmenistan, Uzbekistan, and Yemen.

\section{The International Narcotics Control Strategy Report}

For additional information on money laundering and financial crimes regarding the countries listed below, see the International Narcotics Control Strategy Report, Volume II, Money Laundering and Financial Crimes: https://www.state.gov/2019-international-narcotics-controlstrategy-report/.

Albania, Azerbaijan, Brazil, China, Cyprus, Hong Kong, Macau, Malaysia, Mexico, The Netherlands, Panama, Peru, Philippines, Russia, Thailand, and Turkey. 


\title{
Chapter 1: Country Reports on Terrorism
}

\begin{abstract}
AFRICA

\section{Overview}

African countries and regional organizations sustained ongoing counterterrorism efforts against threats in East Africa, the Sahel, and the Lake Chad region while increasing emphasis on preventing the expansion of terrorist groups, affiliates, and associated organizations into new operating areas in West Africa and Southern Africa.
\end{abstract}

In East Africa, al-Shabaab retained safe haven, access to recruits and resources, and de facto control over large parts of Somalia through which it moves freely and launched external operations attacks in neighboring Kenya. Al-Shabaab maintained its allegiance to al-Qa'ida, remaining intent on limiting the influence and reach of the northern Somalia-based group of ISIS-linked fighters responsible for local suicide bombings and other attacks against Somali security forces in greater Mogadishu.

The African Union Mission in Somalia (AMISOM) and Somali security forces continued cooperation with the United States to exert pressure on al-Shabaab, primarily through coordinated counterterrorism (CT) operations and small advances in governance in southern Somalia. The United States continued to support East African partners across the Horn of Africa in their efforts to build CT capacity, including in aviation and border security, advisory assistance for regional security forces, training and mentoring of law enforcement to manage crisis response and conduct investigations, and advancing criminal justice sector reforms. East African partners undertook efforts to develop and expand regional cooperation mechanisms to interdict terrorist travel and other terrorism-related activities.

In the Lake Chad region, ISIS-West Africa (ISIS-WA) - which split off from Boko Haram (BH) in 2015 - and, to a lesser extent, Boko Haram, continued to conduct attacks against civilians, government, and security forces, which resulted in deaths, injuries, abductions, and the capture and destruction of property. Nigeria, along with its neighbors Cameroon, Chad, Niger, and Benin - and at times in conjunction with the Multinational Joint Task Force - worked to counter these threats, but proved unable to stop ISIS-WA's advance in the region or ensure adequate governance and protection for civilian populations. The United States continued to provide advisors, intelligence, training, logistical support, and equipment to Lake Chad region countries and supported a wide range of stabilization efforts, such as defection, demobilization, disengagement, de-radicalization, and reintegration programming. Continued attacks by $\mathrm{BH}$ and ISIS-WA have taken a heavy toll on the civilian population, especially in northeast Nigeria where attacks have displaced more than two million people and left roughly 10 million in need of humanitarian assistance. 
In the broader Sahel region, terrorist groups have expanded their operations in north and central Mali and the Tri-Border Region of Burkina Faso, Mali, and Niger. These include affiliates of al-Qa'ida and ISIS, such as Jama'at Nasr al-Islam wal Muslimin (JNIM) and ISIS-Greater Sahara (ISIS-GS), respectively, as well as non-aligned groups. The number of attacks in the Western Sahel region increased 250 percent since 2018. Partner countries remain strong willed against terrorism but lack the means to contain or degrade the threat on a sustained basis. The G5 Sahel Joint Force (Burkina Faso, Chad, Mali, Mauritania, and Niger) was launched in 2017 to coordinate counterterrorism operations among member countries. The G5 Sahel is not yet capable of disrupting the growing terrorist footprint across the Sahel but has potential as a coordination mechanism. France's Operation Barkhane, with 5,200 troops on the ground, plays a crucial role in countering terrorist groups and promoting a level of basic security, as does the UN Multidimensional Integrated Stabilization Mission in Mali (MINUSMA).

Terrorists routinely manipulated local communal conflicts and their leaders to support terrorist operations by assisting with long-standing claims against other groups. For example, in Nigeria, terrorists exploited the fighting between the Peuhl and Fulani ethnic groups, as well as the perennial farmer-herder violence over water and grazing areas, to recruit supporters and advance their political and operational interests. Terrorists continued to carry out attacks on military outposts, kidnap western private citizens and humanitarian workers, attack churches, mosques and schools teaching western curricula, and assassinate civil servants and politicians. In Mali, the government has been unable to regain control of northern and central parts of the country. Burkina Faso also experienced increased terrorism in its northern and eastern provinces and in the southern and western parts of the country. There was also a notable uptick in violence in the tri-border region shared by Mali, Niger, and Burkina Faso, which affected all three countries.

Terrorist activities increased in central and southern Africa in 2019. In eastern Democratic Republic of the Congo (DRC), the ISIS-linked Allied Democratic Forces (ADF) attacked Congolese civilians, the DRC armed forces (FARDC), and UN peacekeepers. The group reportedly killed more 300 civilians in Beni Territory as of December 13, with press reporting at least 32 additional deaths as of December 18. The group announced plans for a significant increase in attacks on civilians in response to counter-ADF FARDC operations launched on October 30.

The ISIS affiliate in Mozambique carried out numerous attacks in northern Mozambique, resulting in the deaths of an estimated 350 civilians and the internal displacement of 60,000 people.

South Africa, however, saw a decrease in suspected terrorism-related incidents in 2019, following an unusually high number of incidents in 2018. ISIS facilitation networks and cells that were first publicly acknowledged by the South African government in 2016 remained a threat.

\section{BURKINA FASO}

Overview: Terrorist activity in Burkina Faso rapidly and significantly increased in 2019, as members of JNIM and ISIS-GS conducted the highest level of targeted political assassination, 
the largest attack on civilians, the largest attack on Burkinabe security forces, and the largest attack altogether on a combined population of security forces and civilians. Individuals affiliated with terrorist organizations continue to conduct targeted assassinations, IED attacks, raids on security and military outposts, and to ignite intercommunal conflict and displace local populations in far north and east Burkina Faso. The Burkinabe government conducted the largest CT operations in its history in its northernmost and easternmost regions and continued to increase its intelligence and investigative capacity, but terrorist activities outpaced the government's efforts.

2019 Terrorist Incidents: Terrorist attacks increased in frequency and lethality in 2019, targeting civilians and members of Burkina Faso's security forces. There was a 250 percent increase in terrorist attacks in Burkina Faso from 2018 to 2019. Terrorist groups increasingly appeared to implement a deliberate strategy of hampering security forces' movement in the northernmost region of Burkina Faso by placing IEDs on specific bridges to partially destroy them and prevent heavy vehicles from moving freely.

- During an August 19 attack, about 50 terrorists launched an attack on the Koutougou military outpost, killing at least 24 Burkinabe soldiers and wounding another 13 - the largest attack ever reported against security forces.

- On November 3, terrorist gunmen killed the mayor of Djibo and a parliamentarian of the Sahel region, the highest-level political assassination to date.

- On November 6, individuals affiliated with terrorist groups conducted the largest-ever attack on a civilian population by killing at least 39 people and wounding another 60 in an attack on a convoy carrying employees, suppliers, and contractors of a Canadian mining company.

- ISIS claimed a December 24 attack in which assailants killed 7 security forces personnel and 35 civilians, predominantly women, in the largest attack against both civilians and security forces known to date during Burkina Faso's fight against terrorist organizations. Security forces reportedly killed 80 attackers while defending their base in this incident.

As a result of an increasing number of attacks, Burkinabe security forces have retreated from some military and police outposts in the northernmost region of Burkina Faso. Burkina Faso launched two major CT operations in the East and Center-North regions committing a substantial percentage of available forces in the clearing operations.

Abusive counterterrorism tactics by Burkina Faso's armed forces further exacerbated tensions between civilians and the state, and fueled recruitment of civilians into terrorist groups.

Legislation, Law Enforcement, and Border Security: On May 29, the National Assembly voted into law a new code of criminal procedure, which seeks to abridge criminal proceedings for terrorism cases. The new law eliminated an additional layer of investigations by the Court of Appeal. Instead, upon completion of the investigations, a special chamber will directly adjudicate terrorism and terrorism financing cases, shortening pre-trial timelines. In 2019, the Burkinabe government adopted two decrees for the compensation of defense forces and public servants who are victims of terrorist attacks to galvanize public support in the fight against terrorism. Also in 2019, the National Assembly passed a bill submitted by the government to 
authorize the government to recruit volunteers to defend the homeland. While the Burkinabe government did not prosecute a terrorist in 2019, three cases were ready for trial, and the Ministry of Justice set up a committee chaired by his chief of staff to expedite the processing of pending terrorism cases.

The newly created special brigade on anti-terrorism investigations (BSIAT, for Brigade Spéciale des Investigations Antiterroristes) reached operational capacity in August 2019 and closed 18 of the 31 total cases opened since then, leading to the arrest of 78 terrorist suspects. BSIAT continues to lack a budget for fuel, phone service, and other basic logistical needs, such as food for detainees. BSIAT has initiated dialogue with joint military and gendarme units to improve access to military information, which has resulted in the unintentional consequence of creating confusion on whose authority prevails in terrorist investigations.

Countering the Financing of Terrorism: Burkina Faso is a member of the Inter-Governmental Action Group against Money Laundering in West Africa (GIABA), a FATF-style regional body. Burkina Faso's FIU, the National Financial Information Processing Unit (CENTIF-BF), is a member of the Egmont Group, an informal network of FIUs aimed at combating money laundering and terrorist financing. Burkina Faso's FIU CENTIF in the Ministry of Economy and Finance tracks terrorist financing and concluded 18 investigations in 2019, which included cases of fraud, money laundering and terrorism financing that were referred to the Attorney General's office for further action.

Countering Violent Extremism: Burkina Faso remains interested in countering terrorist radicalization and recruitment. The government planned to inject \$249 million in 2019 to support the Sahel Emergency Plan (Plan d'Urgence pour le Sahel - PUS) to strengthen the role of government, enhance community law enforcement, and generate economic opportunities in its Sahel region. The Burkinabe government completed more than 50 percent of the plan's overall activities by 2019. Further recognizing the value of a holistic approach, the task force developing the Burkinabe government's National Security Strategy has named social cohesion and coexistence, sustainable human development, and strengthening resilience to terrorism as three of the strategy's four pillars. With USAID support, the Ministry of Territorial Administration is considering a consultative framework and strategy to consult religious leaders on CVE issues.

International and Regional Cooperation: Burkina Faso held the rotating presidency of the G5 Sahel in 2019, and continued to work with G5 partner countries Mali, Mauritania, Niger, and Chad to coordinate their regional response to terrorism and crime. Against a backdrop of a rising terrorist threat, Burkina Faso convened an extraordinary summit on counterterrorism for members of the Economic Community of West African States (ECOWAS) and G5 Sahel heads of state on September 14 in Ouagadougou. During the summit, ECOWAS member states agreed to set up a $\$ 1$ billion fund from 2020 to 2024 to invest in mutual CT priorities that include border security, terrorism financing, information sharing, and intelligence coordination. Burkina Faso maintains one peacekeeping battalion in Mali as part of the United Nations Multidimensional Integrated Stabilization Mission in Mali. Burkina Faso's total UN contribution exceeds 1,626 personnel in support of six Peacekeeping and Special Political Missions. 


\section{CAMEROON}

Overview: In 2019, Cameroon experienced a resurgence of terrorist activity in the Far North Region. While the Government of Cameroon attributed most terrorist attacks to BH, ISIS-WA likely perpetrated a significant number of assaults. A December 11 Amnesty International report stated that 275 people were killed by BH and ISIS-WA in 2019, nearly double the number in 2018. Terrorists targeted civilians in villages on the western border with Nigeria and in the northern tip of the Far North Region, within the Lake Chad Basin. They carried out ambushes, abductions, raids, beheadings, and targeted killings of vigilance committee members. The terrorists targeted significantly more soldiers and military posts compared with 2018.

In 2019, ISIS-WA transitioned from seizing resources, often extorting illegal taxes from locals, to attacking villages and security forces in the northern tip of the Far North Region. In June, ISIS-WA perpetrated an attack on Darak Island near Lake Chad that resulted in at least 24 deaths, 16 of which were security forces. This was the largest number of casualties from an attack since BH's initial penetration into Cameroon in 2014. Following at least two separate attacks, ISIS-WA fighters hoisted their black flag in localities within the region.

In May 2019, the government opened the border crossing with Nigeria at Amchide, Far North Region that had been closed since 2014. The border closing had had repercussions for trade with Nigeria and Chad. In July, the government announced a $\$ 2.5$ million project that will benefit youth in areas most affected by BH. In August, President Paul Biya provided financial and material support to vigilance committees engaged in the fight against BH and ISIS-WA. While some efforts were made to establish the rehabilitation and reintegration center for BH recruits in Meme, Far North Region announced by the government in 2018, the center had not yet become operational. Significant numbers of ex-combatants abandoned $\mathrm{BH}$ and surrendered to security forces.

Cameroon continued its CT cooperation with the international community. Over the course of the year, Cameroon contributed to Multi-National Joint Task Force (MNJTF) operations, including providing intelligence, surveillance, and reconnaissance flights by two U.S.-donated C-208 Cessnas. Cameroon also remained a member of the Global Coalition to Defeat ISIS and a member of the Trans-Sahara Counterterrorism Partnership (TSCTP). Countering terrorist threats remained a top security priority for the Government of Cameroon, which continued to work with the United States to improve the capacity of its security forces. In 2019, the United States' CT assistance to Cameroon included an increase in projects implemented by the Department of Justice and the Global Center for Cooperative Security.

2019 Terrorist Incidents: In a December 11 report, Amnesty International stated that in 2019, BH and ISIS-WA killed at least 275 people in attacks on the Far North Region, compared to 153 in 2018. This represents an increase of nearly 80 percent in fatalities in 2019, compared to 2018. L'Oeil du Sahel newspaper, which regularly tracks terrorist-related casualties in the region, estimated that between January and November, BH and ISIS-WA fighters killed at least 111 civilians and 32 security force members. Attacks included indiscriminate killings, targeted 
murders, abductions, ambushes, arson, and raids in search of supplies. A representative sample of attacks in the Far North Region include:

- February 8: BH terrorists killed at least five civilians in Majirde.

- April 12: Four soldiers died in Gouzda-Vreket when their vehicle passed over an IED, allegedly placed by $\mathrm{BH}$.

- April 18: BH terrorists killed at least 10 civilians in Tchakamari.

- June 10: ISIS-WA terrorists killed at least 16 soldiers and 8 civilians in Darak, an island in Lake Chad.

- July 30: BH terrorists cut off the ears of at least three women they abducted following an attack on Gakara.

- August 1: BH terrorists killed at least four civilians in Gederou.

- September 13: ISIS-WA terrorists killed at least six soldiers and injured nine others in Soueram.

- October 21: BH terrorists killed at least four civilians and abducted several others in Goledje.

- October 31: BH terrorists killed at least four civilians in Kotséhéré.

Legislation, Law Enforcement, and Border Security: In 2019, Cameroon prosecuted numerous BH-affiliated defendants for terrorism-related crimes, primarily in the military tribunal in Maroua. Most trials that the U.S. Embassy observed in February at the Maroua military tribunal related to individuals who were alleged to have provided logistical support to $\mathrm{BH}$, as opposed to actual fighters. The low conviction rate is due in large part to poor charging decisions by prosecutors at the outset of cases and to subsequent lack of credible evidence to support convictions at trial. The lack of trial evidence is often the result of an absence of live witness testimony, which is not required under Cameroonian law but is increasingly expected by judges deciding cases.

Cameroon continued to use the anti-terrorism law enacted in 2014 to suppress criticism and freedom of expression by arresting journalists and activists in connection with the ongoing crisis in the Anglophone regions. In October, the government released 333 low-level detainees arrested for suspicion of being Anglophone separatists and facing misdemeanor charges. However, hundreds of others remain in detention. The government continued to characterize people espousing separatism for the Northwest and Southwest Regions as terrorists and, in August, sentenced separatist leader Julius Ayuk Tabe to life imprisonment.

Countering the Financing of Terrorism: Cameroon is a member of the Task Force on Money Laundering in Central Africa (GABAC), a FATF-style regional body. Cameroon's FIU, the National Agency for Financial Investigation, is a member of the Egmont Group. There were no significant updates in 2019.

Countering Violent Extremism: Disarmament, Demobilization, and Reintegration (DDR) remains the focus in the Anglophone regions, where a significant number of former terrorists abandoned BH and surrendered to security forces. In July, national DDR coordinator Francis Fai Yengo told former fighters at a MNJTF camp in Mora, Far North Region, that the government would finance their economic projects. 
In July, the government launched a "Youth and Stabilization for Peace and Security" project within the Far North Region. This project envisions promoting tolerance and coexistence, and will finance studies, trainings, and the establishment of income-generating activities for 30,000 youths ages 12 to 25 from six of the municipalities most affected by the security crisis in the Far North Region. The United Nations and the European Union are providing technical and financial support to this initiative, estimated at $\$ 2.5$ million.

Cameroon's Council of Imams and Muslim Dignitaries organized a three-day seminar in July aimed at building the capacity of 300 imams and preachers on the ills of "religious extremism." The training envisioned promoting tolerance and peaceful coexistence irrespective of religion and educating Muslims that BH's extreme ideology does not represent Islamic principles.

International and regional Cooperation: No changes since 2018.

\section{CHAD}

Overview: In 2019, Chad experienced an estimated twofold increase in the number of terrorist attacks in the Lake Chad region from the previous year. Though the magnitude of the average attack has lessened since 2018, BH returned to the tactics of suicide bombing and IEDs, which had not been seen in several years. BH continued to be the most active terrorist organization in Chad, and ISIS-WA maintained a presence, predominantly in the Lake Chad area, as well. The Government of Chad (GoC) remained a reliable partner of U.S. and other CT missions, even as financing continued to constrain operations. Security forces and basic government services remained underfunded, which limited the GoC's effectiveness, but Chadian armed forces still led missions throughout the region to maintain security in the Sahel. Chad provided about 1,200 combat forces to Lake Chad Region's Multi-National Joint Task Force (MNJTF); however, shortly before the end of 2019, these forces redeployed to Chad. Chad maintained a strong commitment to fight terrorists even in the most dangerous corners of the Sahel and deployed forces to Mali and Burkina Faso. Chad continued to host the French Operation Barkhane, France's CT mission for the Sahel. The United States provided significant support for Chad's Special Anti-Terrorism Group and began a multi-year training program to establish a CT Investigation Unit.

2019 Terrorist Incidents: BH and ISIS-WA continued attacks around the eastern and northern shores of Lake Chad at a pace of approximately two per week. Many of these were small raids to plunder supplies, but terrorist groups also mounted several larger attacks of 100 or more fighters on Chadian military outposts. The reemergence of suicide bombings by young women on civilian targets in Chad heightened tensions. Several Chadian military units were also attacked with IEDs, including one in May that killed four Chadian soldiers and one journalist. In October, terrorists kidnapped a doctor and two nurses, all employees of the Chadian Ministry of Health, to provide treatment to wounded terrorist fighters. The hostages have not been recovered and the incident has spurred further deployments of Chadian security forces to the region. 
Legislation, Law Enforcement, and Border Security: The new Director General of National Police proved very supportive of U.S. CT efforts in 2019. The National Police coordinated with the Anti-Terrorism Assistance (ATA) program to select a group of law enforcement and military officers from multiple agencies to form a new CT investigation unit and gave them a compound from which to operate.

Securing borders remains a difficult task throughout the region. Porous borders on all sides, particularly across Lake Chad, provide easy passage for terrorists and criminal entities alike. Border security remained a shared task of the Gendarmes, Army, Customs, and the National and Nomadic Guard (GNNT), none of which is resourced sufficiently. The Army and GNNT comprised the front line in nearly all major incidents involving $\mathrm{BH}$ and ISIS-WA. At official ports of entry, both air and ground, Chad continued to be a partner in the PISCES program, which screens travelers against domestic terrorist databases.

Countering the Financing of Terrorism: Chad is a member of GABAC. Chad's FIU, the National Agency for Financial Investigation, is a member of the Egmont Group. There were no significant updates in 2019.

Countering Violent Extremism: In September, the executive director of the American-Islamic Congress visited Chad for a speech, which was organized through the Department of State Bureau of Educational and Cultural Affairs in response to the Chadian High Council for Islamic Affairs' request for an American Muslim speaker. The speaker used a variety of private, public, and media events to reinforce themes such as tolerance, inclusion, and women's empowerment. The High Council participated in cultural exchanges with and in the United States and stated that religious leaders' role is to keep and promote peace as well as connectedness with others.

International and Regional Cooperation: Chad is a leader in exporting security throughout the region. Surrounded by conflict, Chad supported CT and peacekeeping forces through numerous international organizations and provided many of the most effective military units in the most dangerous parts of central Africa. In support of the MNJTF, 1,200 Chadians traveled to Nigeria to face $\mathrm{BH}$, and Chad deployed 2,600 service members to joint border security operations as part of this task force and the G-5 Sahel. The Chadian Army sent another 600 soldiers to conduct security operations on the border with Sudan. Again in 2019, Chad supported the United Nations Multidimensional Integrated Stabilization Mission in Mali (MINUSMA) with 1,425 soldiers trained by the United States. In all cases, Chadians have demonstrated the willingness and ability to engage and defeat terrorists. As a result, Chad is highly sought after for contributions to regional missions.

Chad maintains close working relationships with France, and the French Operation Barkhane launches CT missions throughout the Sahel from its base in N'Djamena. Several other European nations increased their engagement with Chad in 2019 as well, and the GoC also sought security support from less traditional allies. The United States remained the largest direct supporter of Chadian security forces, however, and Chad remained a reliable partner in the region in the fight against terrorism. 


\section{DEMOCRATIC REPUBLIC OF THE CONGO}

Overview: Rebel group Allied Democratic Forces (ADF) established ties with ISIS in late 2018. Before its ISIS affiliation, the ADF previously attempted outreach to Islamist terrorist groups for multiple years, including online posts by some ADF members in 2016 and 2017 referring to their group Madinat Tauheed Wal Mujahedeen while displaying an ISIS-like flag. ISIS publicly recognized ADF as an affiliate in late 2018 and claimed responsibility for ADF attributed attacks starting in April 2019 after an attack on an Armed Forces of the Democratic Republic of the Congo (FARDC) base near Kamango on April 16. The ADF has been present in Beni for years and now includes a majority of Congolese fighters, although the ADF recruits fighters from around the region as well. In 2019, as in previous years, the ADF was responsible for numerous attacks on civilians, the FARDC, and UN peacekeepers. During the calendar year, the Kivu Security Tracker (a joint project between the Congo Research Group and Human Rights Watch) documented 310 civilian deaths in North Kivu attributed to the ADF, as of December 13, 2019.

According to the UN, there are more than 100 armed groups operating in the Democratic Republic of the Congo (DRC), yet, historically, the DRC and the international community have generally not referred to these armed groups as terrorists. For political purposes, the government of former President Joseph Kabila labeled certain anti-Kabila domestic armed groups and some opposition party members as "terrorists" for challenging DRC government authority or criticizing the president.

The U.S. government continues to work closely with the Government of the DRC to address potential terrorist threats. In April, newly elected President Felix Tshisekedi visited Washington and publicly discussed the potential for ISIS expansion in North Kivu. During the visit, the DRC formally joined the Global Coalition to Defeat ISIS. During the year, the United States offered training and exchanges in best practices with the FARDC on civil-military operations, strategic planning and messaging, and asymmetric warfare, emphasizing the importance of human rights and the law of armed conflict in CT operations.

2019 Terrorist Incidents: Throughout 2019, the ADF attacked Congolese civilians, the FARDC, and MONUSCO peacekeepers located in Beni Territory, North Kivu and southern parts of Ituri in eastern DRC. The Kivu Security Tracker reported that the ADF had killed at least 310 civilians in Beni Territory as of December 13, with press reporting at least 32 additional deaths as of December 20. A significant increase in planned attacks on civilians was announced by $\mathrm{ADF}$ in response to FARDC operations against the ADF launched on October 30.

Attacks have been conducted against civilians primarily by small groups of fighters, using small arms or machetes for the majority of attacks in areas where the ADF has been present for years. There has not been a significant change in tactics or weapons used since the ADF's public affiliation with ISIS.

Legislation, Law Enforcement, and Border Security: The DRC has no comprehensive CT legislation. The DRC's National Assembly passed a draft counterterrorism bill in December 2018, which stalled in the Senate and was not finalized in 2019. Civil society activists and 
others expressed concern that, if passed as written by the previous Kabila administration, the law could be used as a tool to suppress opposition parties and political dissent. In a significant shift from the previous reporting period, national police leadership attended several international fora on combating terrorism, including Global Coalition to Defeat ISIS meetings and INTERPOL CT training.

The DRC shares approximately 6,835 miles of land and lake borders with nine countries and lacks the capacity to effectively patrol its borders. The authority responsible for monitoring frontier activity, the Director General of Migration, uses the International Organization for Migration's Migration Information and Data Analysis System (MIDAS), a computerized personal identification and recognition system, at only a fraction of the DRC's more than 400 official border crossings. Since 2010, the Department of State's Bureau of International Narcotics and Law Enforcement Affairs (INL) has trained roughly 900 border officers from the National Police's (PNC's) Direction Centrale de la Police des Frontieres Congolaise (Central Border Police Directorate), which oversees security and surveillance activities at border crossings. High turnover rates prevalent throughout the PNC resulted in few INL-trained officers remaining with border units. The PNC anti-riot unit, the Légion Nationale d'Intervention, has a designated CT squad, which has limited staff and receives no specialized training or equipment.

Countering the Financing of Terrorism: The DRC is a member of GABAC.

Following U.S. Treasury sanctions designations in December against Lebanon-based Nazen Said Ahmad and DRC-based Saleh Assi for supporting Specially Designated Global Terrorists, the Government of the DRC took swift action to freeze accounts belonging to sanctioned individuals and companies in the DRC owned, controlled, or directed by them.

Countering Violent Extremism: There were no major changes in 2019. DRC religious institutions including the Council of Bishops (CENCO - Episcopal), the Church of Christ in Congo (ECC - Protestant), and the Islamic community (COMICO), attended a weeklong workshop in Switzerland, led by CENCO, focused on preventing violent conflict in central Africa.

International and Regional Cooperation: The DRC is a member of the Southern African Development Community and the International Conference on the Great Lakes Region. President Tshisekedi has raised the need for regional cooperation with these partners to combat armed groups and bring stability to the eastern DRC.

\section{DJIBOUTI}

Overview: Djibouti remained a critical partner for the United States military and the region in the fight against terrorism. Since 2002, Djibouti has hosted Camp Lemonnier, the headquarters of AFRICOM's Combined Joint Task Force-Horn of Africa and the only enduring U.S. military installation in Africa. The Djibouti-based Inter-Governmental Authority on Development (IGAD) Center of Excellence for Preventing and Countering Violent Extremism (ICEPCVE) expanded operations in Djibouti and in the region by providing CVE training, research, and 
resources. Djibouti's Armed Forces also continued participation in the U.S.-funded Africa Contingency Operations Training and Assistance program and deployed soldiers to the AMISOM campaign.

As in previous years, Djiboutian government officials, particularly law enforcement and members of the High Islamic Council, worked closely to identify and address terrorist activity. Djibouti joined the Global Coalition to Defeat ISIS in 2017.

2019 Terrorist Attacks: There were no terrorist incidents reported in Djibouti in 2019.

Legislation, Law Enforcement, and Border Security: There were no significant terrorism-related legislative changes in 2019. The government used CT legislation to suppress anti-government criticism by detaining and prosecuting political opposition figures and other activists.

Djibouti's law enforcement organization is composed of the Djiboutian National Police (DNP), the Djiboutian National Gendarmerie, the National Security Judiciary Police, and the Djiboutian Coast Guard. The DNP controls border checkpoints and Djibouti's armed forces are responsible for patrolling land borders in remote locations, with support from the Gendarme patrolling between border posts. Djibouti continued to process travelers on entry and departure at its international airport and seaport with PISCES. While the airport and seaport remain important entry points, the vast majority of travelers cross into Djibouti by land at one of three land border points, one of which is the Loyada crossing at the Somali border.

The National Anti-Terrorism Taskforce held several terrorism-related exercises to respond to and prevent terrorist attacks at popular landmarks such as hotels. The taskforce continued its collaboration with the foreign militaries stationed in Djibouti.

In 2019, the Ministry of Justice created a national commission of experts from the Ministry of Foreign Affairs and ICEPCVE to finalize work on a national strategy to combat terrorism.

Countering the Financing of Terrorism: Djibouti is a member of the Middle East and North Africa Financial Action Task Force (MENAFATF), a FATF-style regional body. In 2019, Djibouti's FIU (SRF) organized four events on Anti-Money Laundering and Countering Financing of Terrorism (AML/CFT):

- Two workshops on AML/CFT with the Center on Cooperation and Security Studies in October 2019.

- Two trainings for relevant personnel in the Ministry of Justice, the Ministry of Budget, and the Ministry of Economy in partnership with the European Union, FATF, the Egmont Centre of FIU Excellence and Leadership, France, the International Monetary Fund, and IGAD.

- The signing of an MOU by SRF on the exchange of financial information with countries in the region: Ethiopia, Somalia, and Tanzania. 
There were no published law enforcement cases involving suspected terrorist financing in 2019, although SRF referred several cases of money laundering to law enforcement authorities.

Countering Violent Extremism: From July 1-3, 2019, ICEPCVE conducted a three-day CVE workshop, which brought together 25 religious leaders from the region to discuss their role in preventing religious intolerance at the community level. Participants created multilingual public service announcements that were shared across the region to promote religious tolerance. From 2018-2019, ICEPCVE used a U.S. government grant to solicit CVE research from academics in East Africa, providing $\$ 5,000$ sub-grants to independent researchers to conduct CVE studies in their respective countries. The research was concluded in December 2019 and will be presented at a regional conference. Law enforcement agencies continued to work with the High Islamic Council to identify and monitor activity that promoted terrorist ideology.

International and Regional Cooperation: In 2019, there were no significant changes. Djibouti hosts IGAD's headquarters offices and secretary general. The Djiboutian military continued its participation in AMISOM, which includes military forces from Burundi, Ethiopia, Kenya, and Uganda.

\section{ERITREA}

Overview: In May 2019, the Department of State removed Eritrea from the list of countries certified as "not cooperating fully" with U.S. CT efforts pursuant to section 40A of the Arms Export Control Act. Eritrea had been on the list since 2008. In considering this annual determination, the Department of State reviewed Eritrea's overall level of cooperation with U.S. efforts to combat terrorism. The Government of Eritrea took positive preliminary steps toward engagement with the United States on law enforcement and security in 2019. A lack of transparency from the Eritrean government means there was no clear picture of the methods it used to track terrorists or protect its citizens. In July and October, the government held initial coordination meetings with several U.S. law enforcement and CT-related agencies, opening a channel for information sharing and potential cooperation.

2019 Terrorist Incidents: There were no terrorist incidents in Eritrea in 2019.

Legislation, Law Enforcement, and Border Security: The Eritrean government continues to require all citizens to obtain an exit visa before airport departure. Eritrea has poor internet connectivity, which makes use of the INTERPOL databases and biometric screening and information sharing at ports of entry problematic. However, Eritrea does coordinate with INTERPOL, and customs and immigration officials do use INTERPOL notices or API/PNR data. In July, the Eritrean government signed a partnership framework agreement with UNODC for comprehensive capacity building assistance to upgrade criminal justice and border security infrastructure, equipment, and practices. 
Countering the Financing of Terrorism: In September 2019, Eritrea was admitted as an observer and membership candidate in the Eastern and Southern Africa Anti-Money Laundering Group (ESAAMLG), a FATF-style regional body. Eritrea is a member of the Common Market for Eastern and Southern Africa, which has a maritime security program that focuses on building the capacity of law enforcement agencies to combat money laundering and the financing of terrorism.

Countering Violent Extremism: The government employs awareness raising campaigns, early warning tools, and community-level engagement to prevent and counter terrorist radicalization and recruitment. It actively cultivates an ethos of social inclusion and mutual respect across the nine traditional ethnic groups, as well as among the leading religious denominations that make up Eritrean society. It actively participates in regional CVE conferences, including one on "Empowering Youth and Promoting Tolerance" in Abu Dhabi from December 18-19.

International and Regional Cooperation: The government participated in an expert workshop on protecting critical infrastructure against terrorist attacks held in Johannesburg in November. The government is a member of East African Police Chiefs and hosted a regional workshop for East African law enforcement agencies.

\section{ETHIOPIA}

Overview: Ethiopia's political reform process continued in 2019 under Prime Minister Abiy Ahmed, facilitating even greater counterterrorism cooperation with the United States. The continuing threat of al-Shabaab (AS) and ISIS emanating from Somalia is the Government of Ethiopia's (GOE's) core terrorism concern and the focal point of its security apparatus and the Ethiopia National Defense Force's (ENDF) CT efforts. In 2019, the GOE increased its collaboration with the United States on regional security issues and participated in trainings. The GOE has provided the United States information, evidence, and access to witnesses who have contributed to FBI cases related to AS and other U.S.-designated terrorist organizations.

2019 Terrorist Incidents: There were no confirmed terrorist incidents in Ethiopia in 2019.

Legislation, Law Enforcement, and Border Security: The GOE uses its 2009 Anti-Terrorism Proclamation (ATP) to prosecute crimes associated with terrorist activity. A Legal and Justice Affairs Advisory Council under the attorney general amended the ATP in 2019 in line with the broader opening of political space in the country. The amended proclamation was submitted to and approved by Ethiopia's Council of Ministers (COM) and as of 2019 is awaiting final approval by the House of Representatives. Several Ethiopians arrested in relation to the June assassinations were charged under the 2009 ATP.

The Attorney General's office is working on revising Ethiopia's Criminal Procedure Code to allow for more efficient CT prosecutions while still respecting rule-of-law standards; the U.S. Embassy in Addis Ababa worked with the GOE to include cooperation arrangements with relevant international partners, including the United States, on criminal matters in its revised Code. As of 2019, the revised Code is with the COM for review prior to submission to the House of Representatives for approval. 
The ENDF, the Ethiopian Federal Police (EFP), Ethiopian intelligence, and regional special police worked to block AS attacks in Ethiopia. The Ministry of Peace, which oversees the EFP and intelligence services, increased its public messaging, peace-building activities, and coordination role to combat the influence of AS and other groups. The National Intelligence and Security Service continued to reorganize and reform to focus on collecting intelligence to detect and disrupt terrorism in support of EFP and attorney general efforts to conduct law enforcement investigations and prosecutions.

Border security was a persistent concern for the GOE, and the government worked to tighten border controls with Eritrea, Kenya, Somalia, Sudan, and South Sudan. Ethiopia employed PISCES to conduct traveler screening and watch listing at airports and other points of entry. The GOE, in October, signed a memorandum of cooperation with U.S. Customs and Border Protection to implement the Automated Targeting System-Global, which complements PISCES and will allow the GOE to collect, use, and analyze API/PNR data.

The U.S. Transportation Security Administration (TSA) continues to conduct semi-annual inspections of Ethiopia's national carrier and annual assessments of Bole International Airport. TSA partnered with security officials at Bole to provide aviation security assistance on two occasions in 2019. The next assessment at Bole was scheduled for March 2020. The relationship with Ethiopian aviation security officials is positive. Ethiopia and the U.S. government concluded an arrangement to share terrorist identities to enhance immigration and border controls.

Countering the Financing of Terrorism: Ethiopia is a member of ESAAMLG, and Ethiopia's FIU, the Ethiopian Financial Intelligence Centre, is a member of the Egmont Group. In October 2019, Ethiopia demonstrated progress in addressing strategic deficiencies in its AML/CFT system and was removed from FATF's compliance process.

Countering Violent Extremism: The Ministry of Peace is the GOE's lead on CVE, a priority for Prime Minister Abiy's government given the threat from AS. The GOE's strategy focuses on reducing poverty and ethnic strife to eliminate factors that the GOE assesses enable AS recruitment. The GOE remains engaged in local mediation and conflict mitigation strategies to defuse ethnic and religious tensions, especially in the Oromia, Afar, and Somali regions. The GOE monitored "extremist" activities, particularly among the large Muslim youth population and given the significant economic migration of Ethiopians to the Middle East. Some economic migrants return to Ethiopia radicalized.

International and Regional Cooperation: The GOE has attempted to improve its CT cooperation with Kenya and the Federal Government of Somalia to combat threats. Ethiopian officials remain more willing since Abiy's selection to cooperate with the U.S. government against AS.

The GOE participated in African Union (AU)-led CT efforts as part of AU Mission in Somalia forces. At the AU, Ethiopia participated in CT-related efforts. Ethiopia participates in the IGAD and its CT programs and trainings, including the IGAD Security Sector Program, which builds 
regional capacity to mitigate, detect, and deter terrorist activity. In multilateral efforts against terrorism, the GOE generally supports international directives that seek to stem terrorism. IGAD, recognizing that terrorism is a transnational issue, continued to encourage the cross-border dissemination of information concerning terrorist activity.

\section{KENYA}

Overview: In 2019, Kenya suffered its worst terrorist attack in four years when al-Shabaab (AS) attacked the Dusit D2 hotel complex in Nairobi. The use of a suicide vest and the targeting of civilians were notable. Additionally, the region bordering Somalia continued to suffer attacks, particularly through IEDs and ambushes targeting Kenyan security forces and important infrastructure.

A member of the Global Coalition to Defeat ISIS, Kenya is a willing U.S. partner in CT investigation, prosecution, and incident response, and plays a leading role in regional CT cooperation. The Kenya Defense Forces (KDF) continued to participate in AMISOM and supported border security and counter-IED efforts within Kenya. Security services responded to numerous terrorist incidents, while also disrupting AS and ISIS attack planning, recruitment, and travel. Reports of human rights violations by security forces during CT operations continued, including allegations of extra-judicial killings, disappearances, and torture. In responding to the January 2019 DusitD2 Hotel attack, Kenyan security forces demonstrated improved procedures in line with international standards for protection of human rights in response to terrorist threats and attacks.

2019 Terrorist Incidents: Terrorist incidents in 2019 included the following:

- On January 15-16, AS operatives attacked the Dusit2D hotel complex in Nairobi, killing 21 people and wounding 28 others.

- On February 16, media reported that AS killed three Christian teachers at a primary school in Wajir County, a predominantly Muslim region.

- On April 15, media reported that AS fighters killed one police officer and abducted two Cuban doctors in Mandera town.

- On June 15, an IED planted by AS destroyed a police vehicle, killing 11 police officers and injuring one in Wajir County. The attackers also abducted three Kenya Police Reservists, according to government and media reporting.

- On October 26, media reported that AS used an IED to kill 11 General Service Unit (GSU) officers in Garissa County.

- On December 6, AS attacked a public bus and killed six police officers and four civilians in Wajir County, according to media and government reporting.

Legislation, Law Enforcement, and Border Security: Kenya's government continued to use the Prevention of Terrorism Act (amended in 2014) to investigate and prosecute terrorism. Terrorism case trials often proceeded slowly and inefficiently. For example, the three remaining defendants in the 2013 Westgate Mall attack are still on trial as of December. Most delays are caused by crowded court dockets and the lack of continuous trials. However, 2019 saw significant victories. In March, the Supreme Court reinstated the convictions and 15-year 
sentences of two Iranians in a disrupted 2012 bomb plot that included scouted locations in Nairobi and Mombasa. In June, a Kenyan court found three of four defendants guilty of the 2015 Garissa University massacre. Despite these successes, some challenges persist. The government has yet to fund a public defender service, which is critical to the success of its National Legal Aid Action Plan. Access to defense counsel for terrorism suspects is limited. In February, the Office of the Director of Public Prosecutions (ODPP) published national pleabargaining rules, incorporating them into the Criminal Procedure Code. Since then, the ODPP has been working to develop a uniform and consistent nationwide policy on plea negotiations. The effective use of plea agreements could provide a mechanism for lower-level accomplices to cooperate against higher-level terrorism suspects.

CT functions are divided among the three branches of the National Police Service: 1) the Kenya Police Service (including the paramilitary GSU; Traffic Police; and regional, county, and local police); 2) the Directorate of Criminal Investigations (including the investigative Anti-Terrorism Police Unit, Bomb Disposal Unit, and Cyber Forensics Investigative Unit); and 3) the Administration Police (including the Border Police Unit). The National Intelligence Service, elements of the KDF, and the interagency also shared responsibility. Uneven coordination, resource constraints, insufficient training, corruption, and unclear command and control continue to hinder counterterrorism effectiveness. Kenya's National Counterterrorism Center (NCTC) continued to work with private security companies on preventing soft target attacks. Kenya began preparations in 2019 to establish an interagency Joint Terrorism Task Force.

Terrorists continued to exploit Kenya's largely uncontrolled land borders to conduct attacks. In 2019, Kenyan officials continued to build a border security strategy, but hurdles remain. Under a June 2018 arrangement, Kenya is anticipated to receive U.S. Automated Targeting System-Global (ATS-G) software, which facilitates screening of air travelers using API/PNR. If deployed, ATS-G would be integrated with PISCES, the U.S. government-provided front line border management system, enhancing the capabilities of both systems to target potential threats and counter terrorist travel. However, the passage of a data protection law in November has delayed the implementation of ATS-G. To improve aviation safety and security at Nairobi's International Airport, the Kenyan government established interagency Joint Operations Centers at several points of entry to promote information sharing. Immigration officers also employed government watchlists. Watchlist screening and basic equipment at smaller ports of entry were generally lacking.

The Kenyan government worked to prevent the transit of FTFs, including Kenyans attempting to join AS or ISIS, and those returning from abroad. Kenyan security services also detected and deterred terrorist plots and responded to dozens of terrorism-related incidents. The Kenyan government cooperated on threat information and security at the U.S. Embassy, including through a dedicated GSU CT response team funded by U.S. assistance.

Countering the Financing of Terrorism: Kenya is a member of ESAAMLG. There were no significant updates in 2019. 
Countering Violent Extremism: Kenya established County Action Plans for CVE in all 47 counties to further implement its National Strategy to Counter Violent Extremism. The NCTC is seeking increased resourcing to implement these plans. The NCTC also led Kenya's Country Support Mechanism for GCERF, which awarded grants for community CVE initiatives. Police in Nairobi, coastal, and northeastern counties participated in community engagement training and early warning and response programs. Prison and justice sector stakeholders improved handling of terrorist suspects and convicts, and judicial officials are working to improve management of remand prisoners through plea bargaining and other methods. NCTC's "piloting" of small-scale efforts to disengage, rehabilitate, and reintegrate former terrorists lack a clear legal framework and supportive public messaging campaigns. The Kenyan government hosted a high-level, international CT/CVE conference in July 2019. Kenya's second-largest city, Mombasa, is an active member of the Strong Cities Network.

International and Regional Cooperation: Nairobi continues to host the UN headquarters in Africa. The KDF continued participation in AMISOM and is a member of the Global Coalition to Defeat ISIS. Although not a member, Kenya frequently participated in regional meetings of the GCTF and hosted a GCTF workshop in February.

\section{MALI}

Overview: The Government of Mali (GOM) is receptive to U.S. CT assistance. Terrorist activities increased in quantity and lethality in 2019, and continued to target civilians, Mali's Armed Forces (FAMa), international peacekeepers, and international military forces. Terrorist groups active in Mali include ISIS in the Greater Sahara (ISIS-GS) and JNIM - the umbrella group formed by the Sahara Branch of al-Qa'ida in the Islamic Maghreb, al-Murabitoun, Ansar al-Dine, and the Macina Liberation Front. Possibly most concerning in the region is the increasing geographic expansion of terrorist activities, in many cases involving tactical-level cooperation between ISIS-GS and JNIM.

Implementation of the 2015 Algiers peace accord between the GOM and two coalitions of armed groups continued to be limited, largely hindering the return of public services and security to northern Mali. Terrorism, insecurity, scarce resources, and a lack of accountability or effective governance resulted in a significant increase in intercommunal violence, particularly in central Mali. The conflict zone has continued to press farther south. Efforts to secure the center of the country in 2019 were hampered by the limited availability of trained FAMa members and increasingly sophisticated and coordinated terrorist attacks against military installations.

Mali has been cooperative in working with the United States to prevent acts of terrorism against U.S. citizens. Malian security forces successfully disrupted several terrorist plots targeting softtarget venues frequented by Westerners in Bamako, such as hotels and restaurants; they arrested numerous terrorist suspects and seized stockpiles of weapons and explosives. 
Mali continued to rely heavily on MINUSMA and French forces to help marginally stabilize and secure the northern and central regions. The French military's Operation Barkhane, an integrated CT mission for the Sahel region, continued efforts to target terrorist elements operating in Mali. MINUSMA maintained its presence in northern Mali in 2019 while taking on a greater role in protecting civilians in that region.

2019 Terrorist Incidents: JNIM and ISIS-GS continued to conduct terrorist attacks. There were multiple terrorist incidents including the following significant attacks:

- On January 20, JNIM conducted a complex attack on a MINUSMA base near Aguelhok, in the Kidal region, which killed 10 Chadian peacekeepers and wounded 25.

- On June 9, armed men believed to be affiliated with JNIM killed at least 35 people in an attack against the predominantly Christian town of Sobane Da, Mopti Region, according to media reports.

- On September 3, an IED struck a civilian bus in Mopti, leaving 14 people dead and 24 wounded. JNIM later issued an apology stating it regretted the deaths of "our brothers and sons" and that the IED was intended for the "French occupier and its acolytes."

- On September 30, near the Burkina Faso border, simultaneous attacks on a FAMa post in Mondoro and a joint FAMa-G5 Sahel Joint Force base in Boulkessi by groups presumed to be terrorist elements left at least 38 FAMa soldiers dead, 17 wounded, and as many as 27 missing, according to the government's mid-October reports. JNIM subsequently took responsibility for the attack, claiming to have killed 85 soldiers.

- On November 1, members of ISIS-GS attacked a military base at Indelimane, Menaka region (near the border with Niger), killing at least 54 soldiers. Authorities believe the perpetrators used a stolen Red Cross vehicle to approach the base.

Legislation, Law Enforcement, and Border Security: There were no changes to Mali's CT legal framework in 2019. Mali's highest criminal court tried 19 terrorism cases in 2019. At least 12 of the cases resulted in convictions and sentences ranging from five years to life imprisonment.

Over the past year, the National Gendarmerie's Security and Intervention Group (French acronym GSIGN), a U.S. embassy-trained advanced intervention unit, has been deployed to the Segou region in support of the government's stabilization efforts. The unit supported current gendarme posts, conducted patrols, and investigated suspicious activities. Further gains were stymied by logistical constraints, including the lack of suitable patrol vehicles. An expansion of the GSIGN program will create an additional six operational teams and provide logistical support, including vehicles, to conduct CT operations outside of Bamako.

Malian law specifies that two of the services of the FAMa, the National Gendarmerie and the National Guard, carry out law enforcement CT tasks when called on by the Ministry of Security, the parent agency of the National Police. They perform such functions ineffectively. Mali's interagency coordination and information sharing remain rudimentary. Resource constraints, corruption, malfunctioning of the judicial system in prosecuting terrorist cases, lack of training and automated national criminal report management system for effective law enforcement, and insufficient border security all hamper Mali's CT efforts. 
Although Mali has basic border security enforcement mechanisms, law enforcement units lacked capacity, training, and the necessary equipment to secure Mali's porous borders, which extend about 4,500 miles and touch seven countries. The Gendarmerie, which reports to both the Ministry of Defense and the Ministry of Security (MOS), and the National Border Police, which reports to the MOS, both provide support to prevent and deter criminal activity at borders. Customs officials under the Ministry of Economy and Finance monitor the flow of goods and enforce customs laws at borders and ports of entry. Mali receives INTERPOL notices, but the INTERPOL database is unavailable at some points of entry. Exit and entry stamps used by border officials have inconsistent size and shape, undermining efforts to authenticate travel documents. The government receives Public Key Infrastructure certificates for passport security information from the International Civil Aviation Organization (ICAO); however, the information sharing is done manually and inconsistently.

Malian passports, including diplomatic and official versions, incorporate security measures including micro-printing, ultraviolet features, and a full-color digital photo. Imposters can obtain fraudulent documents, such as birth and marriage certificates, with relative ease, effectively undermining the veracity of Malian identification documents.

The GOM has made some progress toward the implementation of UNSCR 2396 regarding border security, by implementing biometric screening at established ports of entry. However, Mali has little or no control over its borders; terrorists move across borders with ease.

Countering the Financing of Terrorism: Mali is a member of GIABA. Mali's FIU, the National Financial Intelligence Processing Unit, is a member of the Egmont Group. There were no significant updates in 2019.

Countering Violent Extremism: Mali launched a new CVE strategy for the center of the country. The strategy focuses on improving governance, reinforcing security, promoting development, and increasing communication with local citizens about the government's actions. In February the government issued a decree creating a national secretariat under the Ministry of Religious Affairs and Worship for the implementation of a new national CVE strategy. The Ministry of Religious Affairs is responsible for the national strategy for the "prevention of radicalization and terrorism," as well as working with religious associations to maintain a secular state. The Ministry of Religious Affairs has been hampered in its efforts by a lack of resources and coordination with other ministries. Religious leaders in Mali continue to call for religious toleration and denounce "extremist activity."

International and Regional Cooperation: Mali remained active in regional organizations and international bodies, including ECOWAS, the UN, the AU, and TSCTP. The Malian military participated in multinational border security operations under the G-5 Sahel mandate. ECOWAS leaders pledged \$1 billion in September 2019 to fight terrorism in the Sahel, including in Mali. Although not a member, Mali also participated in GCTF regional workshops and events. 


\section{MAURITANIA}

Overview: Mauritania remained a strong security and regional CT partner for the United States in 2019. Despite continued terrorist violence in neighboring Mali and regional threats that included those against Mauritania, the country has not suffered a terrorist attack on its soil since 2011. The government has continued its CT cooperation with the United States and welcomed opportunities to participate in U.S.-sponsored CT-focused trainings. Countering terrorist activity remains a top priority for the Mauritanian government and armed forces, and this message is vigorously underscored by Mauritanian military leadership when appealing to donor nations for equipment and training assistance. Restrictions on U.S. assistance to Mauritania under the Trafficking Victims Protection Act have limited U.S. foreign assistance for Mauritanian CT efforts. On November 14, Iyad Ag Ghali, the leader of JNIM, made new threats against the Sahel countries, including Mauritania, that collaborate with France in the fight against terrorism. In a seven-minute audio recording, the JNIM leader explained that the group was targeting the Sahel countries because of their alliance with France and asserted that the group's latest attacks reflect the "failure" of the G5 Sahel Joint Force.

2019 Terrorist Incidents: There were no terrorist incidents in Mauritania in 2019.

Legislation, Law Enforcement, and Border Security: There were no new terrorism cases pending before the courts. The Ministry of Justice's counterterrorism division is still working on two case files from last year in which six individuals arrested on drug trafficking charges are being investigated for possible links to terrorist groups.

Countering the Financing of Terrorism: Mauritania is a member of MENAFATF. Throughout 2019, the government took steps to combat the financing of terrorism and money laundering. In April, the Central Bank ordered 691 money transfer offices closed for failure to comply with the 2005 Law Against Money Laundering and Financing of Terrorism. In October, the government formally created the National Committee to Combat Money Laundering and the National Committee to Combat Terrorist Financing. Chaired by the prime minister's senior security advisor, the committees include the participation of the Central Bank governor as well as the ministers of economy, justice, interior, and other agencies with a view to improving internal government coordination on these issues. The October decrees creating the committees also replaced the Central Bank's FIU (known as CANIF) with a new Financial Investigations Unit.

Countering Violent Extremism: The Ministry of Islamic Affairs and Traditional Education (MIATE) partnered with the U.S. Embassy to implement CVE activities under the Sadaqa project. Through this partnership, the MIATE facilitated the implementation of at least $85 \mathrm{CVE}$ activities that reached more than 2,500 individuals in Nouakchott and the eastern regions of the country. These activities included trainings on radicalization risk factors, conflict mediation, youth engagement, and effective media and communications, and they also leveraged the ministry's adult literacy programs across these regions to conduct CVE events. The U.S. Embassy also partnered with the Ministries of Interior, Youth, and MIATE to design and implement a Youth Mediator for Peace Network consisting of 13 core leaders who implemented 
relevant CVE activities in their respective regions. On October 7, the Ministry of Islamic Affairs launched a CVE center located within the University of Islamic Sciences in Aioun, Hodh el Gharbi region to study various manifestations of terrorism and the best methods to address it.

International and Regional Cooperation: Mauritania hosts the headquarters of the G5 Sahel regional organization, which comprises Niger, Mali, Chad, Burkina Faso, and Mauritania. The G5 combats regional terrorism and promotes development and governance within and across Sahel member countries. Mauritania assumes the rotating presidency of the G5 Sahel in 2020. In June, the Nouakchott-based G5 Sahel Defense College graduated its first class of 36 mid-career officers, which included 16 Mauritanian officers in addition to 20 officers evenly distributed from Mali, Niger, Burkina Faso, and Chad. In September, the G5 Sahel Defense College provided the first session of instruction specifically for officers from the five countries on secondment to the G5 Sahel Joint Force.

On July 29, Mauritania announced that it was sending a representative to the headquarters of the International Islamic Military Counter Terrorism Coalition led by Saudi Arabia.

\section{MOZAMBIQUE}

Overview: Mozambique experienced a significant increase in terrorist activity in 2019. ISIS's affiliate in Mozambique carried out numerous attacks in northern Mozambique and Tanzania, resulting in the estimated deaths of 350 civilians and the internal displacement of 100,000 people. The Government of the Republic of Mozambique continued security operations against the ISIS-affiliated group in 2019 and made numerous arrests of terrorist suspects. In June 2019, ISIS began claiming responsibility for attacks. Reports indicate that from September to November 2019, Russia provided operational support for government-led CT operations. ISIS attacks in this area have threatened employees of an international liquid natural gas consortium, in which a U.S. company is a participant, and have prompted the consortium to approach further investment in Mozambique with caution.

2019 Terrorist Incidents: With limited exception, ISIS's affiliate in Mozambique reportedly conducted weekly or even more frequent attacks on rural villages in Mozambique's northern Cabo Delgado Province. The attacks varied in intensity and scale, but generally included the use of firearms, edged weapons, and arson. The attacks often included the theft of food and other basic supplies and have displaced at least 100,000 people. In 2019, in addition to targeting civilians, ISIS's affiliate in Mozambique conducted increasing attacks against security forces and vehicles. Fighters connected to ISIS's affiliate in Mozambique are frequently reported to wear stolen police or military uniforms. Access constraints and limited reporting on the violence render reports of attacks difficult to verify. The following list details a small fraction of the reported incidents that occurred:

- On February 21, terrorists attacked a convoy associated with the Anadarko Petroleum Corporation between Mocimboa da Praia and the Afungi Peninsula, killing one contractor. 
- On July 3, terrorists killed seven people, including a police officer and two children, in Lidjungo village, Nangade District. ISIS's affiliate in Mozambique claimed responsibility for the attack.

- On September 10, in two separate attacks in Muidumbe and Macomia Districts, ISIS's affiliate in Mozambique burned 70 houses, vandalized a primary school, and set fire to a hospital. They killed seven police officers and one civilian, and allegedly kidnapped four women.

- On October 13, ISIS's affiliate in Mozambique reportedly clashed with Mozambican and Russian security forces, resulting in the deaths of 10 soldiers.

Legislation, Law Enforcement, and Border Security: Mozambique's current CT legislation was passed in 2018. The law provides for the punishment of anyone committing, planning, preparing, or participating in terrorist acts and stipulates punishment for individuals who travel or attempt to travel to join a terrorist organization. As of July 2019, the government reported 130 convictions related to violence in Cabo Delgado Province. To date, prosecutions have been treated as murders, arsons, and assaults, not as terrorist acts.

In 2019, Mozambican law enforcement entities, including the national police force, Rapid Intervention Unit, and National Criminal Investigative Service engaged in CT operations and activity in northern Mozambique. Mozambique does not have a CT strategy to guide operations in the North, and law enforcement agencies lack the training, equipment, and overall capacity to proactively detect, deter, or prevent acts of terrorism. Though law enforcement entities operate as part of a joint task force with military counterparts, coordination, strategic planning, interagency communications, and intelligence sharing remain significant challenges.

Border security remains a significant security challenge for Mozambique. Terrorists are known to cross the porous border into and from Tanzania, which serves as a recruitment and transit point for terrorist and criminal organizations. Government representatives from Mozambique and Tanzania have convened meetings following two 2019 attacks that resulted in the deaths of Tanzanian citizens and have publicly reconfirmed commitments to a 2018 memorandum of understanding between the two countries' police forces.

Countering the Financing of Terrorism: Mozambique is a member of ESAAMLG. Mozambique is also a member of the Asset Recovery Inter-Agency Network for Southern Africa (known as ARINSA). There were no significant updates in 2019.

Countering Violent Extremism: Mozambique does not have a CVE national action plan, as recommended by the UN Secretary-General's Preventing Violent Extremism Plan of Action, but acknowledges the need for a response to terrorist violence that includes community engagement in addition to security force activity. As of November, the government was working on a fiveyear action plan to deter youth from engaging in terrorism. Publicly, the government refers to terrorists as "evildoers" or "insurgents."

International and Regional Cooperation: Mozambique is a member of the AU and the Southern African Development Community but does not regularly engage on counterterrorism efforts within these organizations. Mozambique is a member of the Partnership for Regional 
East Africa Counterterrorism and has security cooperation MOUs with regional and international partners to include Malawi, India, Russia, Tanzania, Uganda, and the United Kingdom (UK).

\section{NIGER}

Niger faces terrorist threats on five of its seven national borders. The Government of Niger (GoN) remains committed to denying terrorists safe haven within its territory. It cooperated with its neighbors and with international partners, including INTERPOL, and is a member of the Global Coalition to Defeat ISIS, the Multi-National Joint Task Force, and the G5 Sahel Joint Force. Terrorist organizations take advantage of Niger's lengthy borders and sparsely populated desert regions to move fighters, weapons, and other contraband. Terrorist organizations recruit among border populations, where access to government services are weak and economic opportunity is negligible. In the West, terrorist organizations leveraged a sense of injustice and a desire for protection stemming from historic farmer-herder violence. Niger's efforts to fight terrorism are challenged by its small defense force, strained coordination between security services, budget shortfalls, and continuing instability in Burkina Faso, Libya, Mali, and the Lake Chad Basin. Instability in the bordering nations has led to multiple terrorist incursions into Niger.

Terrorist groups active in Niger included ISIS in the Greater Sahara (ISIS-GS), BH, ISIS-WA, and JNIM, which is an amalgamation of the Sahara Branch of al-Qa'ida in the Islamic Maghreb, al-Murabitoun, Ansar al-Dine, and the Macina Liberation Front.

2019 Terrorist Incidents: Terrorist organizations carried out dozens of attacks in Niger during 2019. Two main fronts saw attacks: from BH or ISIS-WA in the Southeast, and from al-Qa'ida (AQ) affiliates and ISIS-GS in the West and the Northwest.

- On January 14, an ambulance carrying civilians was struck by an IED in the Tillabery region, two civilians were killed and six were injured.

- On January 28, suspected members of BH attacked a village in the Diffa region. Four civilians were killed and three wounded. Several vehicles and a large amount of food were stolen from the village.

- On February 17, a female suicide bomber likely affiliated with BH or ISIS-WA detonated her vest at a refugee camp in the Diffa region and four civilians were killed.

- On March 27, suspected members of BH attacked a village in the Diffa region. Fourteen civilians were killed. The attackers utilized two suicide bombers and set fire to several residences. The attackers also kidnapped four villagers during this incursion.

- On April 26, suspected members of BH attacked the Doctors Without Borders compound in the Diffa region. Two civilians were injured in the attack. The attackers burned several buildings and vehicles within the compound.

- On October 9, suspected terrorists attacked a village in the Tahoua region and kidnapped the village chief.

- On May 14, a Nigerien Army Special Forces platoon was ambushed in the Tongo region that resulted in $29 \mathrm{GoN}$ soldiers killed and many more wounded. The terrorist attackers were likely affiliated with ISIS-GS. 
- On December 10, attackers struck a Nigerien military base in the Inates region. More than 70 soldiers were killed, and several vehicles and equipment were taken.

Legislation, Law Enforcement, and Border Security: On December 14, 2018, the GoN passed an amendment to its Penal Code that provides either conditional amnesty or a mitigated sentence for terrorists who voluntarily surrender to authorities. Shortly after the passage of the amendment, the GoN adopted on February 14, 2019, a corresponding decree making the Goudoumaria Defection Center an official GoN entity. Together, these two pieces of legislation ratify Niger's National Program for Managing Defectors from BH and ISIS-WA. Following the ceremony, 125 defectors were reinserted into communities throughout the Diffa region. A smaller second wave of defectors are expected to graduate and be reinserted in January 2020, following their successful completion of vocational training.

Niger's laws criminalized acts of terrorism consistent with international instruments and best practices under the civil law system. Niger finalized a National Border Security Strategy in 2018 with support from the U.S. Global Security Contingency Fund, an interagency program between the U.S. Departments of Defense, Justice, and State. In December 2019, Niger's National Assembly passed an amendment to last year's law defining the conditions under which a person associated with BH or ISIS-WA could benefit from support services, allowing increased international cooperation for the Disarmament, Deradicalization, and Reintegration (DDR) of former BH participants.

Counterterrorism investigations are primarily the responsibility of the Central Service for the Fight against Terrorism and Transnational Organized Crime (SCLCT-CTO), an interagency body comprising representatives from Niger's National Police, National Guard, and Gendarmerie. Niger continued to use rudimentary terrorism watchlists that it shares with the security services and at border checkpoints. Since 2017, it moved more than 700 of about 1,400 BH-related detainees fully through its criminal justice system.

Niger is recognized by regional partners as a leader in processing and prosecuting terrorist incidents using dedicated counterterrorism apparatuses such as SCLCT-CTO and the Special Antiterrorism Judicial Pole. SCLCT-CTO benefits from specialized training, equipment, and persistent mentorship provided by DOS's ATA Program. The GoN also signed an agreement with the U.S. government to establish protocols to improve the use of battlefield evidence and train Nigerien security forces accordingly.

Niger continues to enhance its capacity to detect and deter terrorist incursions at its borders and ports of entry through the expansion of new technologies, critical infrastructure development, and additional specialized security forces assigned along the border, including:

- PISCES;

- MIDAS, and coordination with INTERPOL;

- Direction de la Surveillance du Territoire headquarters and communications build out - funded by INL;

- Cellule Mixte de Contrôle des Frontières, the Groupes d'Action Rapides Surveillance et Intervention, and GIS; and, 
- A joint Regional Security Office/Operation Safe Corridor border security training initiative focused on the Burkina Faso border departments of Say, Ayorou, Tera, and Torodi.

Although the GoN recognizes the importance strengthening its borders in the fight against terrorism, it was dependent on international partnerships to fund and implement these initiatives.

Countering the Financing of Terrorism: Niger is a member of the Inter-Governmental Action Group against Money Laundering in West Africa, a Financial Action Task Force-style regional body. There were no significant updates in 2019.

Countering Violent Extremism: The Government of Niger undertook CVE projects supported by international partners and nongovernmental organizations, including CVE radio programming, sensitization caravans, peace committees, and youth symposia. Local leaders in Diffa continued DDR efforts supported by the Ministry of Interior and the High Authority for the Consolidation of the Peace. Local authorities have set up and trained more than 400 village-level peace committees to strengthen communities' involvement in monitoring and addressing terrorist threats.

International and Regional Cooperation: Niger is a member of and contributes troops to MNJTF and the G5 Sahel. Nigerien officials hosted and attended multiple international meetings on stabilizing Libya and on countering BH or ISIS-WA.

Niger is also a member of ECOWAS and is party to its agreements on counter-trafficking and illicit financing. Nigerien President Issoufou Mahamadou chaired an ECOWAS Summit on Terrorism in Ouagadougou on September 14, 2019, aimed at coordinating efforts among West African nations to combat terrorism. Niger is a member of the TSCTP.

\section{NIGERIA}

Overview: $\mathrm{BH}$ and ISIS-WA continued attacks against government and security forces and civilians in the Northeast, resulting in deaths, injuries, abductions, and the capture and destruction of property. ISIS-WA generally focused on attacking government and security forces and applying increased pressure on transport routes across Borno State, and it tried to cultivate stronger ties with local communities, including by providing limited social services and eliminating moderate leaders. BH attacks did not appear to discriminate between civilians and government officials when conducting attacks.

Nigeria worked with affected neighbors under the Multinational Joint Task Force to counter BH and ISIS-WA and regain control over territory. However, civil society and Nigerian press reported significant human rights issues with the government's counterterrorism efforts, and $\mathrm{BH}$ and ISIS-WA continued to enjoy nearly complete freedom of movement throughout northern Borno State and eastern Yobe State. 
To date, terrorist actions by BH and ISIS-WA have contributed to the internal displacement of about two million people within the states of Adamawa, Borno, and Yobe, and the external displacement of more than 240,000 Nigerian refugees to neighboring countries, principally Cameroon, Chad, and Niger. On October 5, the Bring Back Our Girls (BBOG) campaign marked 2,000 days since 276 students were abducted by BH from Chibok, Borno State, in 2014. According to BBOG representatives, 112 students remained missing at the end of 2019. BBOG organizers noted that while most of the 113 students abducted from Dapchi, Yobe State in 2018 had been released, one student remains in the custody of insurgents.

Nigeria is a member of the Global Coalition to Defeat ISIS, the TSCTP, and the U.S. Security Governance Initiative. The Department of Defense continued to coordinate with the Nigerian military at the Nigerian Defense Intelligence Agency, the Joint Combined Fusion Cell, and the Joint Coordination Planning Committee.

2019 Terrorist Incidents: BH and ISIS-WA carried out hundreds of attacks in Nigeria using small arms, captured military equipment, IEDs (including person-borne and vehicle-borne), ambushes, and kidnappings. The following list details only a fraction of the incidents that occurred:

- On February 12, suspected ISIS-WA terrorists attacked the convoy of then-Governor of Borno State as it drove from the capital of Maiduguri to a town near Nigeria's border with Cameroon; as many as ten were reportedly killed.

- On June 12 , suspected BH terrorists killed at least 30 people and injured 42 when three IEDs were detonated at a market in Konduga, Borno State.

- On July 18, suspected ISIS-WA terrorists attacked a convoy of Action Against Hunger (AAH) and health ministry employees in Borno State. One AAH driver was killed, while one AAH staff member, two drivers, and three health ministry workers remained missing, reportedly taken as hostages. On September 25, media reported ISIS-WA said it had executed one of the missing aid workers. On December 13, ISIS-WA said it had killed four of the five remaining hostages.

- On July 27, suspected BH terrorists killed at least 65 people near the Borno State capital. Local officials said that, while some were killed as they returned from a funeral procession, around 40 civilians were killed when they pursued their attackers. Officials also said this may have been a reprisal attack as two weeks earlier, residents had repelled an attack killing 11 suspected terrorists.

- On 26 December, ISIS-WA released a video claiming to show the execution of 11 Christians and claimed the killings were revenge for the killing of ISIS leader Abu Bakr al-Baghdadi.

Legislation, Law Enforcement, and Border Security: There were no changes to Nigeria's CT legal framework in 2019. The draft Terrorism Prohibition and Prevention Bill of 2017 lapsed at the close of the 2018 National Assembly and must be re-introduced. 
The Office of the National Security Advisor (ONSA) is responsible for coordinating all security and enforcement agencies, including the Department of State Security (DSS), Nigeria Security and Civil Defense Corps (NSCDC), Ministry of Justice, and Nigeria Police Force (NPF), which has a CT Unit and Terrorist Investigation Branch.

The government continued processing hundreds of individuals suspected of supporting BH and ISIS-WA. Despite their acquittal, at the end of the year many of these individuals remained in detention facilities in Niger and Borno states awaiting completion of a mandated deradicalization program or transfer to state-owned transit centers for reintegration into their home communities. For example, in November, nearly a thousand individuals in Borno State were released from Giwa barracks to the Bulumkutu rehabilitation center. These individuals are expected to remain in transit centers while the International Organization on Migration conducts individual data collection and screening. Human rights groups alleged that terrorist suspects detained by the military were denied their rights to legal representation, to due process, and to be heard by a judicial authority.

Border security responsibilities are shared among the NPF, DSS, NSCDC, Customs, Immigration, and the Nigerian military. Coordination among agencies was limited. The Nigerian government continued to work with the FBI to investigate specific terrorism matters, predominantly through the DSS. ONSA and the NPF provided IED components to the FBI for analysis at the Terrorist Device Analysis Center.

Countering the Financing of Terrorism: Nigeria is a member of GIABA. Nigeria's Financial Intelligence Unit (NFIU) was readmitted to the Egmont Group in 2018 after implementation of a law that made the NFIU independent of the Economic and Financial Crimes Commission (EFCC). There were no significant updates in 2019.

Countering Violent Extremism: The government continued Operation Safe Corridor, aimed at identifying and reintegrating former low-threat supporters of terrorist organizations. OSC increased the de-radicalization program from 12 weeks to a 24-week program in recognition of the effort needed to conduct vital activities such as capacity building and profiling individuals at the center. By year's end, at least 268 individuals, including 86 children, had completed the program and were reintegrated into society.

Building on the National Action Plan on Disarmament, Demobilization, Repatriation, Reintegration (DDRR), which was endorsed by the Nigerian Government in 2018, the ONSA convened the DDRR Action Plan Operational Project Team (OPT) in January. The OPT is tasked with implementing the ten outcomes listed in the DDR action plan. Members of the OPT include ONSA, OSC, the Joint Investigation Committee, the Defence Intelligence Agency, Defence Headquarters, the Nigerian Prison Service, the NPF, the International Organization on Migration, and state representatives. 
International and Regional Cooperation: Nigeria continued high-level participation in regional security and CT conferences. Nigeria is a member of GCTF and co-chairs the GCTF Criminal Justice and Rule of Law Working Group with Switzerland. Nigeria also is an International Institute for Justice and the Rule of Law Board Member. In September, Nigeria hosted a delegation from GCERF.

\section{SENEGAL}

Overview: Although there were no reported terrorist attacks in Senegal in 2019, the Government of Senegal increasingly considers itself a likely potential target given ongoing terrorist activities in West Africa. In light of these concerns, Senegal continued to work closely with U.S. military and law enforcement officials to strengthen its CT capabilities.

The risk of terrorist activity in Senegal arises from external and internal factors. Externally, the growing terrorist threats across the region and the prevalence of multiple active terrorist groups in neighboring Mali risks spilling across the border into Senegal and threatening stability. Senegal has taken steps to combat this threat, particularly in Mali, by contributing troops to MINUSMA. Internally, the promotion of "extremist ideologies" by a small number of religious leaders constituted the chief concern; however, these ideologies remain outside Senegal's prevailing Islamic norms.

2019 Terrorist Incidents: There were no reported terrorist incidents in Senegal in 2019.

Legislation, Law Enforcement, and Border Security: There were no significant changes to Senegal's CT legal framework in 2019. Senegal continued to enhance the capabilities of its Inter-Ministerial Framework for Intervention and Coordination of CT Operations (CICO). CICO, formed in 2016, is designed to coordinate the government's response to terrorism.

In 2019, the Superior Court of Dakar adjudicated and published written decisions on three terrorism cases, two involving online threats, and a third involving money transfers to insurgent hotspots in Mali. Resolution of all three cases involved international cooperation (two with France and the third with Mali). At the end of 2019, the court was also handling three cases with possible terrorist links. One involved the seizure of AK-47 ammunition stolen from a military depot in Dakar. The second involved $12 \mathrm{~mm}$ ammunition purchased from a Lebanese munitions dealer in Dakar and destined for Mauritania. In both cases, the alleged drivers of vehicles seized transporting the ammunition caches reported making several similar trips before being apprehended. The third case involved a legislator caught in an undercover operation selling false currency, including West African CFA francs, Euros, and U.S. dollars, with a face value exceeding \$50 million. The legislator was arrested after a cooperating witness identified him as the distributor in the false-currency ring.

Senegal's gendarmerie and national police have specialized units to detect, deter, and prevent acts of terrorism. Challenges remain to effective interagency cooperation and information sharing between the various governmental bodies that have CT functions in the country. 
Senegal continued to improve its law enforcement capacity by participating in multilateral efforts, such as the GCTF's West Africa working group, AU programs, and ECOWAS.

Additionally, Senegal continued to work with the International Organization for Migration to promote cooperation and coordination between border agencies.

Senegalese officials remained concerned that gaps in border protection resources and regional cooperation created security vulnerabilities. These vulnerabilities were exacerbated by the absence of systems to verify travel document security, the effective use of terrorist screening watchlists, and the capabilities of biographic and biometric screening collection beyond those deployed at major ports of entry. To combat these vulnerabilities, as of December 2019, the Senegalese government agreed to sign in January 2020 a Memorandum of Understanding to implement U.S. Custom and Border Protection's Automated Targeting System-Global.

Countering the Financing of Terrorism: Senegal is a member of GIABA. Senegal's FIU, the National Financial Intelligence Processing Unit (CENTIF), is a member of the Egmont Group. In September 2019, Senegal's Ministry of Finance issued three implementing decrees to clarify and fill gaps in the provisions of its 2018 AML/CFT law. These decrees created the National Anti-Money Laundering Committee to strengthen domestic coordination of AML/CFT efforts, strengthen oversight of certain businesses and professions that handle large volumes of money (attorneys, casinos, and nongovernmental organizations), and reorganize and enhance the autonomy of CENTIF.

Countering Violent Extremism: There were no changes in 2019.

International and Regional Cooperation: Senegal is a member of the AU, ECOWAS, the Organization of Islamic Cooperation, and TSCTP. Although not a member of the GCTF, Senegal participated in regional workshops and activities held by the GCTF West Africa Region Capacity Building Working Group. The French and the EU provided financial support and training to reinforce Senegal's CT and border security capabilities. In November, the Government of Senegal hosted the Sixth Dakar International Forum on Peace and Security in Africa, which continued to focus on terrorism and related regional instability.

\section{SOMALIA}

Overview: The Federal Government of Somalia (FGS) remained a committed partner of the United States in the ongoing fight against al-Shabaab (AS) and ISIS-Somalia, taking significant steps to implement security sector and other institutional reforms designed to improve its CT capabilities. However, AS retained de facto control over significant portions of the country, particularly in south-central Somalia, continuing to move freely, collect "taxes," and exert governing authority in the areas under its control. AS conducted multiple significant and highprofile terrorist attacks in Somalia and appeared to increasingly use targeted assassinations against key government figures and community leaders to undermine the credibility and effectiveness of Somali government institutions.

AMISOM, Somali National Army (SNA), and U.S. forces increased the level of pressure against AS in parts of Somalia in 2019, primarily intending to disrupt the flow of IEDs into the capital 
Mogadishu. In April 2019, in cooperation with the United States and AMISOM, the FGS launched an operation to retake key territory near Mogadishu from AS control; the FGS is preparing further operations for 2020.

AS also continued to attack targets in the border area between Somalia and Kenya. Further, ISIS-Somalia remains involved in fundraising, intimidation campaigns, and assassinations in Mogadishu and northern Somalia. Somalia is a member of the Global Coalition to Defeat ISIS.

2019 Terrorist Incidents: Key terrorist incidents within Somalia in 2019 included:

- On February 28, three VBIED attacks in Mogadishu killed at least 30 people near the popular Makka al-Mukarama hotel. AS claimed responsibility.

- On March 23, in a complex attack that lasted several hours, attackers killed at least five people, including the Deputy Minister of the Ministry of Labor and Social Affairs, after detonating multiple IEDs in Mogadishu, including at a government compound hosting Labor and Social Affairs and the Ministry of Public Works. AS claimed responsibility.

- On July 12, one American died after a complex attack - involving a VBIED and multiple gunmen - on the Asasey hotel in Kismayo, Somalia. Media reported 27 total casualties. AS claimed responsibility.

- On July 24, a blind female suicide bomber killed herself and seven other people, including Mogadishu Mayor Abdirahman Omar Osman, during a security meeting in the mayor's office. AS claimed responsibility.

- On September 30, assailants detonated a VBIED outside Baledogle Military Airfield, then launched an attack at the SNA base. SNA forces repelled the attack with no deaths or injuries. On the same day, a VBIED targeted an EU convoy in Mogadishu, injuring multiple Somali civilians. AS claimed responsibility.

- On December 28, more than 80 people were killed by a truck bomb on the outskirts of Mogadishu, according to preliminary reports. AS claimed responsibility.

Legislation, Law Enforcement and Border Security: FGS remained a willing partner to U.S. efforts to improve the quality of policing entities throughout the country, especially the CT and criminal investigation capabilities of the Somali Police Force (SPF). In 2019, the FGS took renewed interest in police reform, appointing new leadership to key posts, including the SPF commissioner. Additionally, on September 8, the Office of the Prime Minister, the Ministry of Justice, Military Courts, the Attorney General's Office, the Ministry of Internal Security, SPF, and the Somali Bar Association approved a U.S.-supported roadmap for transferring serious cases from military to civilian courts.

Countering the Financing of Terrorism: Somalia is a member of MENAFATF. In 2019, FGS continued to strengthen institutional AML/CFT efforts, including support for the Financial Reporting Center, the country's FIU, which began operations in November 2018. Commercial banks and "hawala" money transfer bureau compliance officers, in accordance with legislation and regulations, have been submitting suspicious transaction and large currency transaction reports to the FRC on a monthly basis. The Central Bank of Somalia adopted its first-ever strategic plan, which identified full implementation of an AML/CFT framework as its number one strategic goal. 
Somalia finalized AML/CFT regulations in September, which will operationalize the government's ability to monitor financial transactions and take action to investigate potential terrorism financing. The government also adopted regulations governing mobile money transactions in August to close gaps in the AML/CFT regime and more closely monitor the substantial movement of money through services provided by the telecommunications sector.

Countering Violent Extremism: The FGS Office of the Prime Minister is responsible for coordinating government efforts and international support for CVE. The Prevention and Countering Violent Extremism Coordinator was established in 2018 and now leads a regular working group. The National Strategy for Public Awareness was established by the Ministry of Information, Culture, and Tourism in 2018 as a three-year strategy that includes specific lines of effort for CVE through the media. Following the February 2017 presidential election, the FGS announced its intent to offer amnesty to any AS member willing to denounce terrorism and support the FGS. A donor-supported effort to reintegrate former AS combatants continues, primarily through reintegration centers operating in Mogadishu, Kismayo, and Baidoa. Somalia is also a newly established GCERF beneficiary country.

International and Regional Cooperation: The FGS continued to partner closely with AMISOM to help enable the transition of security responsibilities from AMISOM to Somali security forces. Between February and March 2019, 1,000 Burundi National Defense Forces left Somalia as part of the first scheduled drawdown for AMISOM forces. The next drawdown of AMISOM forces is scheduled for February 2020.

\section{SOUTH AFRICA}

Overview: South Africa saw a decrease in suspected terrorism-related incidents in 2019, following an unusually high number of incidents in 2018. ISIS facilitation networks and cells remained a threat, after being first publicly acknowledged by the South African government in 2016. Regional dynamics were an increasing concern as terrorist groups made gains in parts of the South African Development Community region, including Mozambique. The government continued to prosecute alleged terrorists charged in previous years and arrested members of an alleged white supremacist terrorist group.

2019 Terrorist Incidents: There were no reported terrorist incidents in 2019.

Legislation, Law Enforcement, and Border Security: There were no changes to South Africa's legislative framework in 2019. The Protection of Constitutional Democracy Against Terrorist and Related Activities Act criminalizes acts of terrorism, as well as the financing of terrorism, and sets out specific obligations related to international cooperation. The Regulation of Foreign Military Assistance Act of 1998 applies to nationals who attempt to or who have joined terrorist organizations like ISIS. The Crimes Against the State Unit within the Directorate for Priority Crime Investigation, and South Africa's State Security Agency are tasked with detecting, deterring, and preventing acts of terrorism within South Africa. The South African Police Service (SAPS) Special Task Force is specifically trained and proficient in CT, counterinsurgency, and hostage rescue. The National Prosecuting Authority (NPA) is committed 
to prosecuting cases of terrorism and international crime. The Department of Justice submitted a cybercrimes bill to Parliament in 2017, aimed at halting the spread of malicious communications over the internet. Parliament is still reviewing the bill.

Border security is challenging in South Africa because of to its numerous land, sea, and air ports of entry for international travelers. South Africa has multiple law enforcement agencies policing its borders, but they are often stove-piped. Inadequate communication, along with a lack of equipment, limits their border control ability. The Department of Home Affairs submitted the Border Management Authority Bill to Parliament in 2016 to create an integrated and coordinated agency to ensure effective control of the border. Parliament is still reviewing the bill. CT measures at the international airports include screening with advanced technology X-ray machines, but land borders do not have advanced technology and infrastructure. Trafficking networks made use of these land borders for many forms of illicit smuggling. Citizens of neighboring countries are not required to obtain visas for brief visits. Regulation of visa, passport, and identity documents remained a challenge within South Africa. The SAPS internal affairs office investigated allegations of corruption within the Department of Home Affairs concerning the illicit sale of passports and identity documents, but the use of illegitimately obtained identity documents continued.

In 2019, South Africa's NPA continued to prosecute terrorism crimes. In an effort to decentralize prosecution of terrorism cases, and to provide opportunities for provincially based prosecutors to gain experience in terrorism cases, the NPA's Gauteng-based Priority Crimes Litigation Unit (PCLU) returned prosecutors seconded to the central unit back to their previous provincial assignments and reassigned terrorism cases to attorneys in the judicial districts where the crimes occurred. Although the PCLU retained an oversight role, it gave provincial prosecutors substantial autonomy to direct terrorism cases as they see fit. Progress in several high-profile cases slowed as newly assigned NPA provincial prosecutors had to become familiar with the cases and develop prosecutions strategies. These included the previously reported prosecutions of the terrorist group allegedly responsible for the 2018 attacks on a Shia mosque and incendiary attacks against commercial interest in Durban, as well as of Sayefudeen Del Vecchio and Fatima Patel, who were charged in 2018 with the killing of British-South African dual nationals Rodney and Rachel Saunders.

In November, South African Police arrested four members of the National Christian Resistance Movement, a white supremacist group allegedly planning attacks targeting shopping malls, informal settlements, and government installations. In December, the four suspects were charged under the Protection of Constitutional Democracy against Terrorism and Related Activities Act.

Countering the Financing of Terrorism: South Africa is a member of FATF and of ESAAMLG. South Africa's FIU, the Financial Intelligence Centre, is a member of the Egmont Group. There were no significant updates in 2019.

Countering Violent Extremism: The UN CTED 2018 report notes that the 2013 National CT Strategy in South Africa, which continued to be implemented in 2019, is classified confidential because it is operational in nature. The Strategy is based on five pillars: 1) Understanding and 
Prediction; 2) Prevent; 3) Mitigation; 4) Combating; and 5) Response - Dealing with the Consequences. It is supported by an Implementation Plan - as well as time frames for implementation, assessment, and reassessment - and is updated annually.

International and Regional Cooperation: South Africa is a member of the AU, GCTF, and the Southern African Development Corporation.

\section{TANZANIA}

Overview: In 2019, the Governments of Tanzania and the United States engaged in limited CT cooperation, with most of the engagement focused on capacity building and border security. The continuation of terrorist attacks in northern Mozambique, which include both Tanzanian perpetrators and victims, led to continued assurances of Mozambican and Tanzanian crossborder security cooperation.

2019 Terrorist Incidents: On June 26, armed attackers killed 11 people, including nine Tanzanians, in Ntole village, Mozambique. Government sources attributed the attack to Ansar al-Sunna, locally known as "al-Shabaab," a terrorist group since identified to be affiliated with Islamic State - Central African Province in Mozambique. Media reported that the attackers were Tanzanians who planned the attack from within Tanzania. Following the June attack, the chiefs of police from Mozambique and Tanzania met to coordinate the security response.

In November, armed men dressed in Tanzanian Peoples Defense Forces military uniforms killed six villagers in Ngongo village, Mtwara Region, Tanzania. It is believed the attackers came from Mozambique and carried out the attack in response to villagers alerting police to a large group of migrants en route to Mozambique days earlier. Although unidentified, due to the proximity to Cabo Delgado Province in Mozambique, the attackers likewise may have been affiliated with Ansar al-Sunna.

Media and research points to the presence of Tanzanians among East African terrorist groups, including ADF, al-Shabaab, and ISIS. In July, ISIS released a pledge video from the "Wilayah Central Africa." The pledge video, delivered in Swahili, calls on Muslims to unite and pledge allegiance to the "Khalifa." Risks of attacks in Tanzania remain high, exacerbated by possible cooperation among terrorists in the DRC, Mozambique, and Kenya who seek to take advantage of lightly governed spaces and porous borders, including the return of trained and radicalized Tanzanian terrorists from foreign theaters.

Legislation, Law Enforcement, and Border Security: In November 2019, Tanzania amended the Prevention of Terrorism Act to specifically prohibit terrorist financing.

Tanzania serves as a recruitment and transit point for terrorist and criminal organizations that capitalize on vast unguarded border space.

In July, Tanzanian police announced the arrest of five suspects who were associates of the June 26 attackers in Ntole, Mozambique. Bilateral partners and researchers also reported scores of arrests of people attempting to cross from Mtwara, Tanzania, into Cabo Delgado, Mozambique. 
Tanzania's National Counterterrorism Center (NCTC) leads the government's coordination on CT issues but remains under-resourced and maintains no legal mandate to investigate or arrest suspects.

Tanzanian military and police leadership acknowledges the existence of terrorists in Tanzania and Mozambique and claims to be working with local populations to increase border security.

Countering the Financing of Terrorism: Tanzania is a member of ESAAMLG. Tanzania's FIU, the Tanzania Financial Intelligence Unit, is a member of the Egmont Group. In November 2019, Tanzania amended the Prevention of Terrorism Act to include specific mention of prohibiting the proliferation of terrorism financing. Throughout 2019, the United States funded AML/CFT training to Ministry of Finance officials.

In 2019, Tanzania continued efforts to regulate the movement of foreign exchange. While the primary purpose of the restrictions appears to be reduction of tax evasion, the measures also make it easier to trace transactions, including those associated with money laundering.

Countering Violent Extremism: In 2019, NCTC continued its partnership with the UNDP in a multi-year CVE project that began in spring 2017. The UNDP CVE project includes funding to develop a national CVE strategy and action plan, originally envisioned to be completed in 2018. Tanzania and UNDP reportedly made progress on the strategy in 2019 and both institutions assure partners it will be finalized in 2020.

In 2019, the U.S. government provided funding for CVE activities with civil society actors in vulnerable areas. Regional and district government levels do not have a clear understanding of $\mathrm{CVE}$, which has hindered progress in implementing certain measures. Additionally, policecommunity relations, especially in Muslim-majority regions along the coast, are strained due to heavy handed tactics by the police force.

International and Regional Cooperation: In 2019, Tanzania pursued training from bilateral and multilateral donors to enhance CT-related security units. Tanzania has not prioritized working through regional bodies, including the Southern African Development Community and the East African Community on security and CT issues.

\section{UGANDA}

Overview: The Government of Uganda (GOU) continued to make important contributions toward CT efforts in East Africa and the Horn of Africa in 2019. As the largest troop contributing country to AMISOM, Uganda remained a key partner in regional efforts to neutralize al-Shabaab. However, in April, ISIS claimed responsibility for attacks in eastern DRC conducted by the ADF, a historically anti-Kampala armed group based in that area. This was the first claim by ISIS of an attack in the region and highlighted the persistent threat of terrorism in Uganda.

Terrorist Incidents: No terrorist incidents occurred inside Uganda in 2019. 
Legislation, Law Enforcement, and Border Security: The GOU is increasingly concerned by security threats - terrorist and criminal - along Uganda's western border with the DRC, particularly from the ADF, which has a long history of killing civilians and planning attacks against Ugandan interests. However, no notable changes to Uganda's border security posture occurred in 2019, nor were there significant legislation or law enforcement developments specific to CT.

Countering the Financing of Terrorism: Uganda is a member of ESAAMLG, and Uganda's FIU, known as the Financial Intelligence Authority, is a member of the Egmont Group. There were no significant updates in 2019.

Countering Violent Extremism: The GOU has made progress in drafting its CVE national action plan, as recommended by the UN Secretary-General's Preventing Violent Extremism Plan of Action, according to police and military officials. However, the government has not yet shared the draft with security partners, nor committed to a date for its release.

International and Regional Cooperation: Uganda participates in CT efforts through its membership in the United Nations, AMISOM, the Intergovernmental Authority on Development, the East African Community, PREACT, the International Conference on the Great Lakes Region, and the Organization of Islamic Cooperation. Uganda participated in discussions convened by the Government of the DRC with a subset of regional partners twice in 2019 to discuss countering armed groups in eastern DRC. Ultimately, the GOU opted not to participate and the proposed regional operation against the ADF and other armed groups ultimately did not move forward. The FARDC launched a unilateral operation against the ADF on October 31, 2019.

\section{EAST ASIA AND PACIFIC}

\section{Overview}

In 2019, governments in East Asia and the Pacific continued working to strengthen legal frameworks, investigate and prosecute terrorism cases, increase regional cooperation and information sharing, and address critical border and aviation security gaps. Regional cooperation between domestic law enforcement and judicial authorities among countries throughout Southeast Asia resulted in high numbers of terrorism-related arrests and, in many cases, successful prosecutions.

On March 15, 2019, a gunman carried out and live-streamed a terrorist attack on two mosques in Christchurch, New Zealand. Fifty-one people were killed, 50 more were injured, and the livestream was viewed around 4,000 times before being removed by technology companies. Two months later, a group of government leaders and major online service providers adopted a non-binding pledge - the Christchurch Call to Action to Eliminate Terrorist and Violent Extremist Content Online (Christchurch Call) - to prevent terrorist use of the internet. The United States did not endorse the Christchurch Call due to policy and legal concerns, but it supports the overall goals and continues to work with international partners to counter the use of 
the internet for terrorist purposes. This was illustrated by U.S. endorsement of the 2019 G20 Osaka Leaders' Statement on Preventing Exploitation of the Internet for Terrorism and Violent Extremism and the 2019 G-7 Biarritz. Strategy for an Open, Free and Secure Digital Transformation, among others.

Multiple suicide bombings in the Philippines were a new phenomenon for the region. They included a complex attack against a military unit in Sulu, which involved the first Filipino suicide bomber, as well as a suicide attack at the Jolo Cathedral in Sulu, carried out by an Indonesian couple. Southeast Asian governments remained concerned about foreign terrorist fighters (FTFs) returning from Iraq or Syria and using their operational skills, connections, and experience to launch domestic attacks.

Authorities in East Asia and the Pacific actively participated in regional and international efforts to counter terrorism. Australia, Fiji, Japan, the Republic of Korea, Malaysia, New Zealand, the Philippines, Singapore, and Taiwan are partners in the Global Coalition to Defeat ISIS.

Australia, China, Indonesia, Japan, and New Zealand are members of the GCTF. As co-chairs of the GCTF Countering Violent Extremism (CVE) Working Group, Australia and Indonesia organized an annual plenary meeting and workshops on monitoring, measuring, and evaluating CVE programs, CVE in prisons, and the role of gender and civil society organizations in CVE.

Civil society organizations expressed concern that some governments in the region used terrorism as a pretext to target religious minorities and human rights activists. The Chinese government's repressive approach to counterterrorism disregards human rights and relies heavily on mass surveillance, censorship, and mass internment of religious and ethnic minorities. China's CT efforts continue to focus primarily on "extremists" whom Beijing ascribes to the socalled East Turkistan Islamic Movement, despite a lack of independent evidence that a group by that name is still active. The Chinese government has detained more than one million Uyghurs, ethnic Kazakhs, and other members of Muslim minority groups in internment camps in the Xinjiang Uyghur Autonomous Region, using counterterrorism as a pretext.

\section{AUSTRALIA}

Overview: In 2019, Australia strengthened CT laws, investigated and disrupted suspected terrorist plots, and maintained high levels of cooperation with the United States and other international partners. Australia played a major role in the Global Coalition to Defeat ISIS and was a leading contributor to the Coalition's military support, humanitarian assistance, and efforts to disrupt FTFs. Australia was endorsed as a co-chair of the GCTF CVE Working Group for a second term from 2019-2021. At the end of 2019, Australia's National Terrorism Threat Advisory System remained at "Probable," the third-highest level on a five-level scale. The Australian Security Intelligence Organization's 2019 annual report found that "Islamist extremism" remained the principal source of terrorist threat for Australia and reported an increase in REMT, which Australia calls "extreme right-wing terrorism," in recent years.

Australia remains committed to working with partner governments in Southeast Asia to shape a secure and prosperous region through greater cooperation on countering terrorism threats. This includes bilateral engagements and supporting capability development and capacity-building 
activities across the region. The Australian Federal Police (AFP) works with policing agencies in Southeast Asia and has facilitated a series of multilateral CT dialogues.

Australia implemented legislation regarding FTFs returning to Australia. Australian security agencies estimate that about 230 Australian citizens have traveled to Iraq and Syria since 2012. The government estimates that about 80 Australians are currently in Syria/Iraq and have fought for or supported ISIS or similar groups. Australian authorities are aware of 66 Australians in al-Hawl refugee camp in Syria. Australia repatriated eight children from Syria in June.

Since September 2014, Australian CT authorities have conducted 16 major counterterrorism disruption operations in response to potential or imminent attacks in Australia. A further 98 people have been charged as a result of 44 counterterrorism-related operations around Australia.

In 2019, Australia worked closely with the United States to identify and develop new capabilities that meet a wide variety of requirements for countering terrorist threats. Through a cost-sharing bilateral relationship, both countries advanced their technical ability to defeat or mitigate the evolving capabilities of terrorists and criminal organizations. The United States and Australia also worked closely on capacity-building efforts in Southeast Asia.

2019 Terrorist Incidents: Australia experienced no terrorist-related attacks in 2019.

Legislation, Law Enforcement, and Border Security: Australia continued to apply its comprehensive CT legislation against domestic threats and passed additional legislation aimed at addressing external threats. In July 2019, the Australian Government implemented CT legislation to address the threat posed by returning terrorist fighters. Australia introduced the Counter-Terrorism Bill 2019 (Temporary Exclusion Orders), which allows the prime minister to prevent an Australian citizen from reentering the country for up to two years if the person is suspected of supporting, or having fought with, a terrorist organization overseas. In the aftermath of the Christchurch terrorist attacks in March, the Australian Parliament passed the Criminal Code Amendment (Sharing of Abhorrent Violent Material) Act 2019, which came into force in April. The Act adds new offenses to the criminal code concerning online "abhorrent violent" content - defined as murder or attempted murder, a terrorist act, torture, rape, or kidnapping. Under the Act, it is an offense for an internet service provider, content service or hosting service to fail to refer to the AFP "within a reasonable time" (not defined in the Act) abhorrent violent material that the provider is aware could be accessed through or on its service, where the underlying conduct occurred or is occurring in Australia.

New counterterror legislation - Australian Citizenship Amendment (Citizenship Cessation) Bill 2019 - was introduced in September 2019. The legislation stems from concerns that the current counterterror legislation does not cover several current high-risk offenders, including Australian fighters in Syria and several who have returned. The Citizen Cessation Bill would give Home Affairs Minister Peter Dutton new authority to strip dual-national terrorists of their Australian citizenship. The legislation will broaden the number of individuals whom the government can investigate and prosecute for engaging in terror-related activities by backdating the current deadline from December 12, 2015, to May 29, 2003. 
Significant law enforcement actions in 2019 included the following:

- In July, Australian police arrested three men over an alleged ISIS-inspired plot to attack several Sydney targets.

- In December, Australia's Federal Police arrested a 21-year-old man in Sydney on three separate terrorism charges.

Australia's border security remained robust and the country continued to promote international cooperation on information sharing to thwart terrorist travel. Australian authorities are investigating 230 people in Australia for providing support to terrorist groups involved in the Syria/Iraq conflict. Since 2012, around 250 Australian passports have been cancelled or applications refused in relation to the Syria/Iraq conflict.

In September 2019, U.S. Customs and Border Protection (CBP) and the Traveler Branch/Customs Group of the Australian Border Force approved an annex to the Global Entry joint statement that outlines how Australia will vet Australian citizens for U.S. Global Entry membership and how approval information will be shared between Australia and CBP. Australia is in the process of building the infrastructure to collect application information for Australian citizens. The pilot, which will be limited to 500 Australians, is expected to launch in 2020.

Countering the Financing of Terrorism: Australia is a member of the FATF and co-chairs the APG, a FATF-style regional body. The Australian Transaction Reports and Analysis Centre (AUSTRAC), Australia's FIU, is a member of the Egmont Group. Australia is also a member of the Defeat ISIS Coalition's Counter ISIS Finance Group (CIFG). In November, Australia hosted the second "No Money for Terror" Ministerial Conference on Counter-Terrorism Financing, bringing together 65 delegations, including 23 ministers, representatives from 15 international bodies including the United Nations, FATF and FATF-style regional bodies, as well as representatives from 28 private sector and not-for-profit organizations.

Countering Violent Extremism: Australia's CVE strategy remains focused on four overlapping streams that emphasize diversity and social participation, target work with vulnerable communities and institutions, address online terrorist propaganda, and assist diversion and de-radicalization. Australia is active in the GCTF and co-chairs the GCTF CVE Working Group with Indonesia. At the GCTF Coordinating Committee meeting in September, Australia announced that it would partner with Switzerland and the United Kingdom to create a policy toolkit on the Zurich-London Recommendations that outline good practices for CVE and terrorist recruitment online. The Policy Toolkit on the Zurich-London Recommendations was launched in September 2019.

International and Regional Cooperation: Australia is a member of the UN, the GCTF, the Pacific Island Forum, the East Asia Summit, Asia Pacific Economic Cooperation (APEC), the ASEAN Regional Forum, and the Global Initiative to Combat Nuclear Terrorism. At the ninth Trilateral Strategic Dialogue, which convened in April 2019, Australia pledged to cooperate with the United States and Japan to enhance border management practices and strengthen information sharing. In 2018, Australia signed a Memorandum of Understanding with ASEAN outlining 
cooperation on $\mathrm{CT}$, including law enforcement cooperation, capacity building, and technical assistance. Since signing the MOU with ASEAN, AUSTRAC has implemented a regional Financial Intelligence Analyst Course and a Multilateral Analyst Exchange Program.

\section{CHINA (HONG KONG AND MACAU)}

\section{CHINA}

Overview: The People's Republic of China (PRC) response to terrorism remained difficult to distinguish from the government's suppression of peaceful activities that authorities deemed separatist or subversive in nature. The PRC government's CT attention remained on ethnic Uyghur so-called "extremists" whom Beijing ascribes to the East Turkistan Islamic Movement, despite a lack of evidence that a group by that name is still active. The PRC government shared international concerns regarding other terrorist groups such as al-Qa'ida and ISIS, among others.

Using counterterrorism as a pretext, the Chinese Communist Party (CCP) has detained more than one million Uyghurs and members of other Muslim minority groups in internment camps in the Xinjiang Uyghur Autonomous Region since April 2017. Because of their religion and ethnicity, they reportedly have been subjected to political, linguistic, and cultural indoctrination as well as forced disappearance, torture, physical abuse - including forced sterilization and sexual abuse and prolonged detention without trial. Chinese authorities also developed new legal guidelines and law enforcement tools to expand their capabilities to carry out this repressive campaign, which included pervasive, arbitrary, high-tech surveillance; the collection of personal data including DNA samples; compulsory stays by PRC government officials in Uyghur homes; and controls on the expression of cultural or religious observations.

2019 Terrorist Incidents: Details about alleged terrorism-related incidents inside China were difficult to verify due to a lack of transparency and information from PRC authorities. PRC government officials provided few responses to requests from U.S. and other international officials for detailed information on alleged terrorist threats. As in 2018, PRC officials continued to claim that no violent terrorist incidents have occurred in the country since 2016, owing to the government's "new counter-extremism policies," in an attempt to justify Beijing's repressive campaign in Xinjiang.

Chinese citizens abroad were targeted in terrorism-related incidents in 2019. The Baloch Liberation Army continued to link concerns about Chinese activity in the Chinese Pakistan Economic Corridor (CPEC) to terrorist attacks in the region and claimed responsibility for an attack on a Chinese-frequented hotel in Gwadar in May. Chinese citizens abroad were also impacted by other terrorist attacks not specifically directed against PRC government policies. For example, two Chinese citizens were injured in a July attack in Somalia claimed by alShabaab.

Legislation, Law Enforcement, and Border Security: In March, the State Council Information Office published a white paper: "The Fight Against Terrorism and Extremism and Human Rights Protection in Xinjiang," which falsely claimed that the camps were in fact "vocational training and education centers" where detainees learned Mandarin Chinese, national 
laws, vocational skills, and ideas to counter "extremist" thinking. International media reported on the continued mass transfer of Uyghurs and other Muslims to China's interior due to overcrowding at camps in Xinjiang, on efforts to move some detainees to forced labor facilities, and on draconian detention conditions in the facilities, including torture and deaths. Internal PRC government documents published by international media confirmed the coercive nature and prison-like conditions of the internment camps. In August, Chinese media made public the creation of a CT special operations unit in the People's Armed Police (PAP) operating in Xinjiang. Media reports did not indicate when the unit was initially established, but said the unit had passed an evaluation process and was capable of conducting combat missions.

In September, State Councilor and Minister of Public Security Zhao Kezhi stressed the importance of intelligence collection and research, calling for strengthened early warning and precise strikes against terrorist activities, and implementation of real-name airline ticket purchases and security checks. The PRC government continued to leverage its domestic technology sector to bolster its surveillance capabilities, including for alleged CT goals. Police deepened use of closed-circuit television camera networks paired with facial recognition, iris scanning, and other technologies to track, discover, or predict threats to public safety across the country. Although such technology has been used to catch criminal actors, it is also used to monitor and control domestic dissidents and ethnic and religious minorities. The PRC government continued to stress the threat of domestic and international "cyber terrorism," as a continuing pretext to tighten monitoring and censorship of online speech and mobile communications. Next-generation "anti-terrorism" equipment, including assault vehicles and anti-riot vehicles, was displayed during the PRC 70th anniversary military parade in October.

Countering the Financing of Terrorism: China is a member of the FATF, the APG, and the Eurasian Group on Combating Money Laundering and Terrorist Financing (EAG). The PRC is also a member of the Defeat ISIS Coalition's CIFG. There were no significant updates in 2019.

In April 2019, FATF published a Mutual Evaluation Report that reviewed the PRC's compliance with FATF standards and the effectiveness of PRC's AML/CFT system. The report demonstrated a strong overall understanding of China's terrorist financing risks, but noted deficiencies related to the implementation of targeted financial sanctions and understanding of terrorist financing risks among financial and non-financial institutions, businesses, and professions. Brazil, Russia, India, China, and South Africa (BRICS) regularly cooperate on the topic of terrorist financing.

Countering Violent Extremism: The PRC government continued to implement repressive campaigns in Xinjiang under the guise of countering what it called "extremism." Authorities intensified a campaign of mass "re-education" or "vocational training" of Uyghurs and other Muslims, which began in April 2017 with the purported goal of countering "extremism," but whose actual goal the United States assesses to be the repression of religious and ethnic minorities. Uyghurs, Kazakhs, and other Muslims are reportedly forced to learn Chinese, recite slogans in praise of the CCP, and renounce their culture and religion. At a December 10, 2019, press conference, Shohrat Zakir, chairman of the Xinjiang Uyghur Autonomous Region and CCP deputy chief in Xinjiang, announced that all "training" participants had "graduated" but noted the centers would remain open for local residents to participate in Chinese language, legal, 
vocational skills, and de-radicalization training. The PRC government's broad definitions of "terrorism" and "extremism" and its unclear definition of "cyber terrorism" continue to raise serious human rights concerns.

Regional and International Cooperation: The PRC government continued to promote the UN as the primary international forum for counterterrorism, where it actively promotes a repressive approach to counterterrorism. In October, the UN Counterterrorism Executive Directorate conducted its first ever assessment of China's implementation of international counterterrorism obligations. The PRC engaged in a range of multilateral, regional, and bilateral fora, while seeking to present itself as a global leader on counterterrorism. In March, former Vice Foreign Minister Cheng Guoping was appointed to a newly-created position as the Ministry of Foreign Affairs External Security Commissioner, with a mandate to enhance diplomatic outreach on CTrelated topics. In 2019, efforts under these frameworks included a joint border operation, exercises on preventing terrorist use of the internet, and a joint CT drill held in Russia. BRICS meetings, including its fourth Counterterrorism Working Group meeting, reinforced the centrality of CT cooperation. China continued to participate in the Quadrilateral Cooperation and Coordination Mechanism for Counter Terrorism, along with Afghanistan, Pakistan, and Tajikistan. Representatives from 31 countries sent military and police representatives to attend the PAP's biennial Great Wall International Forum on Counterterrorism.

Units from the People's Liberation Army and PAP also held bilateral CT drills with a range of countries including India, Kazakhstan, Russia, Singapore, and Tajikistan, and in July Beijing held high-level talks with Pakistan on how to strengthen CT cooperation to protect CPEC projects. China is a member of the ASEAN Regional Forum, APEC, and the East Asia Summit, and it is also a member of the GCTF. The PRC government hosted 800 officers from ASEAN and dialogue countries for their largest-ever CT exercise in November.

\section{Hong Kong}

Overview: Hong Kong continued its security and law enforcement partnership with the United States through the Hong Kong Customs and Excise Department's joint implementation of the Container Security Initiative.

2019 Terrorist Incidents: No terrorist incidents were reported in Hong Kong in 2019.

Legislation, Law Enforcement, and Border Security: Counterterrorism remained an operational priority for the Hong Kong Police Force. The Police Counterterrorism Response Unit provides a strong deterrent presence, assisting police districts with CT strategy implementation and complementing the tactical and professional support of existing police specialist units such as the Explosive Ordnance Disposal Bureau, the Special Duties Unit, the Airport Security Unit, and the VIP Protection Unit.

In 2018, the Hong Kong government set up the Inter-Departmental Counterterrorism Unit (IDCU) to strengthen overall CT efforts by monitoring global trends, reviewing, and improving CT strategies in Hong Kong, developing specialized CT training, and optimizing emergency response plans. The IDCU held its first exercise in March. 
In 2019, authorities in Hong Kong falsely characterized the acts of pro-democracy and human rights protestors as terrorism. The PRC spokesman in Hong Kong also falsely described the actions of protestors as showing "signs of terrorism."

Countering the Financing of Terrorism: Hong Kong is a member of the FATF and the APG. Hong Kong's FIU, the Joint Financial Intelligence Unit, is a member of the Egmont Group.

In September, the FATF published a Mutual Evaluation Report of Hong Kong, assessing Hong Kong's AML/CFT regime to be compliant and effective overall. The report assessed Hong Kong to be at medium-low risk of terrorist financing and assessed that it has implemented sound systems to detect and investigate terrorist financing when it occurs. It further states that authorities demonstrated "a robust use of financial intelligence and the capacity to conduct complex CFT investigations," although these have not yet exposed proliferation financing cases.

In November 2019, the Hong Kong Monetary Authority hosted Hong Kong's AML/CFT regulatory technology forum, discussing with participants from banks, financial regulators, and law enforcement agencies the use of innovative technology to enhance the efficiency of its AML/CFT ecosystem.

Countering Violent Extremism: There were no changes to Hong Kong's CVE programming in 2019.

International and Regional Cooperation: Hong Kong law enforcement officers attended U.S. government-sponsored capacity building training at the International Law Enforcement Academy on personnel and facility security, law enforcement techniques to counter terrorism, and financial investigations. In January 2019, Hong Kong's representatives joined a tripartite meeting among mainland China, Hong Kong, and Macau to foster cooperation on AML/CFT. Hong Kong is also an APEC economy.

\section{$\underline{\text { Macau }}$}

Overview: Macau's CT cooperation with the United States included information sharing. The Police Intervention Tactical Unit (UTIP), which falls under the Macau Public Security Police Force, is responsible for protecting important installations and dignitaries, and conducting highrisk missions, such as improvised explosive device deactivation. UTIP's Special Operations Group's mission is CT operations. Macau cooperated internationally on CT efforts through INTERPOL and other security-focused organizations.

2019 Terrorist Incidents: No terrorist incidents were reported in Macau in 2019.

Legislation, Law Enforcement, and Border Security: As a gambling center, Macau authorities are aware of the risks associated with junket promoters. They have indicated they are working on further steps, including strengthening the regulatory framework for market entry and intensifying AML/CFT oversight. 
Countering the Financing of Terrorism: Macau is a member of APG. Macau's FIU, the Financial Intelligence Office (FIO), is a member of the Egmont Group. In October, the APG announced that Macau became the first member among the globally evaluated members to demonstrate compliance with all 40 FATF recommendations.

In January and February, supervisory agencies - including the Gaming Inspection and Coordination Bureau, the Finance Services Bureau, the Macau Monetary Authority, and the Housing Bureau - updated their AML/CFT guidelines to reduce the risk of money laundering and financing of terrorism.

Countering Violent Extremism: There were no changes to Macau's CVE programming in 2019.

International and Regional Cooperation: In 2019, the FIO signed separate memoranda of understanding/cooperation for exchange of AML/CFT intelligence with counterparts in the Republic of Kazakhstan and the Federative Republic of Brazil. In January, the FIO hosted a tripartite meeting among mainland China, Hong Kong, and Macau to strengthen cooperation on AML/CFT. In September, the FIO visited the AML Bureau of the People's Bank of China and the China Anti-Money Laundering Monitoring and Analysis Center to further strengthen cooperation and exchange.

\section{INDONESIA}

Overview: Indonesia applied sustained pressure to detect, disrupt, and degrade terrorist groups operating within its borders and deny them safe haven. ISIS-affiliated Jamaah Ansharut Daulah (JAD) and its offshoots continued to target police and other symbols of state authority. While not a member of the Global Coalition to Defeat ISIS, the Indonesian government and Muslim civil society leaders forcefully and repeatedly denounced ISIS and actively promoted the importance of CVE efforts to complement law enforcement CT efforts. Indonesia is an active member of GCTF and co-chairs the CVE Working Group with Australia. The Indonesian, Malaysian, and Philippines' militaries continued coordinated patrols in the Sulu and Sulawesi Seas to deter and prevent kidnapping and terrorist transit in their adjoining exclusive economic zones.

2019 Terrorist Incidents: JAD-affiliated cells and ISIS-inspired lone actors continued to target the police and other government targets:

- On March 12, the wife of a suspected terrorist detonated a bomb, killing herself and her child after refusing to surrender to police in Sibolga.

- On October 10, two ISIS-inspired attackers, a husband and wife, severely wounded Coordinating Minister for Political, Legal, and Security Affairs Wiranto and a policeman in a stabbing attack in Pandeglang.

- On November 13, a 24-year old JAD cell member disguised as a motorcycle taxi driver detonated a bomb vest on the police headquarters compound in Medan, killing himself and wounding four police personnel and two civilians. 
Legislation, Law Enforcement, and Border Security: The Government of Indonesia issued Regulation No. 77/2019 on the Prevention of Terrorism and Protection of Investigators, Public Prosecutors, Judges and Correctional Officers as an implementing regulation under the 2018 Law on Terrorism on November 13. The regulation tasks the National Counterterrorism Agency (BNPT) with preventing terrorism through national preparedness and counterterrorism radicalization and de-radicalization programs. The regulation also provides protection for investigators, public prosecutors, judges, and corrections officers and their families.

From January to December, police arrested approximately 296 terror suspects and killed at least six for resisting arrest. Among those arrested was Para Wijayanto, the suspected leader of al-Qa'ida-linked Jemaah Islamiyah, for his role in the 2002 Bali bombings and other attacks. Indonesia convicted two terror suspects; 42 remain on trial. Additionally in July, the National Police confirmed that an Indonesian couple, Rullie Rian Zeke and his wife, Ulfah Handayani Saleh, were behind the January 27 Jolo Cathedral bombing in the Philippines. The East Jakarta District Court sentenced to death JAD member Suherman on October 9, the first terrorist defendant convicted under the 2018 terrorism law, making him the fourth convicted terrorist on death row. Indonesia last executed convicted terrorists in 2008.

In July, the Indonesian military launched an elite unit - Special Operations Command - to help fight terrorism in the country.

The Government of Indonesia inaugurated a super-maximum-security prison for high-risk convicted terrorists on Nusa Kambangan Island in Central Java on August 22. The Government of Indonesia coordinated and socialized a plan to relocate selected terrorist inmates to the BNPT De-radicalization Center (Pusderad) in Sentul to provide a structured, systematic, focused, and sustainable de-radicalization program in one location.

Border security remained a challenge. The Customs and Excise Directorate General, which collects API/PNR data to screen travelers, continued to experience difficulties with passenger targeting, analysis, management systems, and high-level management turnover. Police maintained a watchlist of suspected terrorists, but lines of communication and coordination among stakeholder agencies were not always clear. Indonesia's Immigration Directorate General uses INTERPOL databases to screen international passengers at key immigration checkpoints in airports and seaports but must rely on the Customs Excise Directorate General for access to API/PNR.

Indonesia hosted the trilateral joint exercise Indomalphi Middle Land Exercise 2019 in Tarakan, North Kalimantan, from July 29 to August 7 as a follow-up to the Sulu trilateral coordinated sea and air patrols launched in June and October 2017 under the Trilateral Cooperative Agreement. This land exercise involved 160 army soldiers from Indonesia, Malaysia, and the Philippines, as well as observers from Singapore and Brunei. The exercise aimed to improve border cooperation among the three countries in fighting terrorism and other transnational crimes in the maritime domain.

Countering the Financing of Terrorism: Indonesia is a member of the APG. Indonesia's FIU, the Indonesian Financial Transaction Reports and Analysis Center, is a member of the Egmont 
Group. Indonesia acquired observer status in FATF in 2018 and is on track toward full membership by 2020. Indonesia is also a member of the Defeat ISIS Coalition's CIFG. In 2019, Indonesia prosecuted and convicted individuals for financing terrorism.

Countering Violent Extremism: BNPT continued its work on a draft CVE national action plan for anticipated release as a presidential executive order. BNPT also managed de-radicalization programs for terrorist convicts. Indonesians deported from third countries for attempted travel to Iraq and Syria were enrolled in a one-month de-radicalization program at a rehabilitation shelter operated by the Ministry of Social Affairs in Bambu Apus, East Jakarta. BNPT used former terrorists for CVE outreach campaigns and helped establish boarding schools to educate children of former terrorists. Indonesia issued a Ministerial Joint Decree on Handling Radicalism among Civil Servants on November 12 and formed a dedicated task force to monitor, investigate, and report online behavior of civil servants accused of "radicalism."

International and Regional Cooperation: Indonesia continued to support CT efforts in several regional and multilateral organizations, including the UN, ASEAN, the ASEAN Regional Forum (ARF), and APEC. Indonesia remained active in the ARF Inter-Sessional Meetings on CounterTerrorism and Transnational Crime and the APEC Counter-Terrorism Working Group. Indonesia hosted the U.S./ASEAN Workshop on Developing National Action Plans on CVE August 5-6. Indonesia continued to use the Jakarta Centre for Law Enforcement Cooperation as a regional training center. Indonesia is a member of the GCTF and co-chairs the GCTF CVE Working Group with Australia. Indonesia hosted the GCTF's CVE Working Group Workshop on Counter and Alternative Narratives in Jakarta on June 24-25.

\section{MALAYSIA}

Overview: Although there were no ISIS-affiliated attacks in Malaysia in 2019, the country remained a source, a transit point, and, to a lesser extent, destination country for terrorist groups including ISIS, Abu Sayyaf Group (ASG), al-Qa'ida, and Jemaah Islamiyah. Suspected ISIS supporters deported from Turkey and individuals linked to ISIS or ASG planning to travel to the southern Philippines used Malaysia as a transit point. Malaysia monitored, arrested, deported, and tried suspected supporters of terrorist groups. Malaysia also cooperated with the United States and others to increase border security capacity at airports and in the Sulu Sea, CT messaging on social media, and to improve terrorist prosecutions. Malaysia is a member of the Global Coalition to Defeat ISIS.

2019 Terrorist Incidents: While no ISIS-affiliated attacks were carried out in 2019, Malaysia remained a transit point and hub for kidnap-for-ransom activities perpetrated by other terrorist networks. On June 18, 10 fishermen were kidnapped off the coast of Lahad Datu in Sabah state by ASG militants. The victims were later rescued and released without harm. On September 4, two armed men believed to be on the lookout for potential kidnap victims or with plans to commit violent acts were killed by local police in Sabah waters. The Eastern Sabah Security Command (known as ESSCOM) announced the security commission was on "high-alert" following the September 23 kidnapping of three Indonesian fishermen and learning that ASG insurgents planned to carry out raids for ransom victims in the East Sabah area. 
Legislation, Law Enforcement, and Border Security: The Ministry of Home Affairs (MOHA) conducted an internal review of the Security Offences (Special Measures) Act 2012 (SOSMA) to consider amending provisions assessed to be draconian or against human rights, according to media reports. The MOHA minister said Malaysian security agencies engaged with civil society organizations, including the Human Rights Commission of Malaysia, to receive input on the law. Malaysian officials contend that SOSMA remains a critical element to fight terrorism and proposed reducing the allowed detention without charge time from 28 to 14 days. However, no legislative amendments to SOSMA or security related laws - such as the Prevention of Terrorism Act (POTA), the Sedition Act, or the Prevention of Crime Act - were announced by year's end.

The Royal Malaysia Police (RMP) Special Branch Counterterrorism Unit has the lead CT law enforcement role. This unit identifies terrorist threats and reported several arrests during the year to prevent planned terrorist attacks. In March, RMP reported the arrests of nine suspects, including six Egyptians and two Tunisians, for suspicion of plans to launch large scale attacks in several countries. The RMP Special Branch Department made the arrests after receiving a tip from intelligence agencies about the presence of suspected terrorist fighters in Kuala Lumpur, Selangor and Sarawak. From July to September, law enforcement reported the arrest of 16 suspects nationwide, which included 12 Indonesians, three Malaysians, and an Indian. The suspects were accused of attempting to establish an ISIS cell in Malaysia and plan attacks in Malaysia and Indonesia. In May, RMP Special Branch announced they foiled a wave of largescale terror attacks and assassinations plotted by an ISIS-linked cell during the first week of Ramadan. Four suspects were arrested during a sting operation on suspicion of planning attacks against religious sites and entertainment venues, the leader of which was charged with terrorismrelated offenses.

Convicted Malaysian terrorist Yazid Sufaat, who was linked to the September 11, 2001, attack in the United States, was released from prison on November 20, 2019. Sufaat has served three separate prison sentences since 2001. In 2017, he was detained under POTA law and released following the expiration of his two-year detention without trial. RMP reports that Sufaat is under strict surveillance; he must wear an electronic monitoring device and report to the police twice a week.

Countering the Financing of Terrorism: Malaysia is a member of FATF and APG. Malaysia's FIU, Financial Intelligence Unit - Malaysia, is a member of the Egmont Group. In October, the government approved legislation establishing the National Anti-Financial Crime Centre (NAFCC) to coordinate financial crime investigations. The NAFCC is intended to direct efforts among Malaysia's enforcement agencies in foreign and domestic financial crime investigations. The NAFCC will house a centralized financial crime data system and include an executive committee that will approve and monitor integrated operations. On November 5, the government launched the MyFINet initiative involving Bank Negara Malaysia, the Royal Malaysian Police, the Royal Malaysian Customs Department, the Malaysian Anti-Corruption Commission, the Securities Commission Malaysia, and 18 reporting institutions. The purpose of MyFINet is to facilitate financial intelligence sharing between law enforcement agencies and reporting institutions to better detect and disrupt terrorism financing and financial crimes. 
Countering Violent Extremism: In 2019, the Ministry of Foreign Affairs Southeast Asia Regional Center for Counter-Terrorism (SEARCCT) launched a number of CVE initiatives, which included counter-messaging programs shared through social media and radio as well as onsite workshops targeting youth. Within the year, SEARCCT organized a nationwide youth program on "Building Community Resilience" and partnered with Deakin University in Australia to strengthen engagement between government and civil society organizations across Southeast Asia. SEARCCT also collaborated with the Ministry of Home Affairs Prison Department to produce a series of interviews with former and current detainees charged with terrorism-related offenses to raise awareness on recruitment practices and narratives of terrorist organizations.

International and Regional Cooperation: Malaysia continued to support CT efforts in regional and multilateral organizations. The Government of Malaysia hosted the May 2019 Global Counterterrorism Workshop under the Terrorist Travel Initiative and the first ASEAN Regional Forum (ARF) workshop on aviation security and UNSCR 2396 in July 2019. Malaysian officials participated in numerous CT events hosted by the UN, the Global Counterterrorism Forum, ASEAN, the ASEAN ARF, APEC, and the East Asia Summit.

\section{PHILIPPINES}

Overview: The Philippine government adapted its military, law enforcement, and counterradicalization efforts to address shifting threats from terrorist groups that continued to operate primarily in the country's South. The Philippines continued to cooperate with the United States, notably enhancing law enforcement and other efforts to address the full spectrum of terrorist threats. Philippine military, law enforcement, and judicial authorities participated in numerous U.S. capacity-building programs, and used the training and equipment they received to prevent and respond to terrorist incidents.

Groups affiliated with ISIS-Philippines continued efforts to recover from battlefield losses, recruiting and training new members, and staging suicide bombings and attacks with IEDs and small arms that targeted security forces and civilians. ISIS-Philippines affiliates active in 2019 included elements of the Abu Sayyaf Group (ASG), Bangsamoro Islamic Freedom Fighters (BIFF), Ansar al-Khalifa Philippines (AKP), and the Maute Group. The Philippines remained a destination for FTFs from Indonesia, Malaysia, and countries in the Middle East and Europe.

The Philippine government and the Moro Islamic Liberation Front (MILF) made progress toward a political settlement of long-running insurgencies. In January, residents of the region passed a referendum to ratify the Bangsamoro Organic Law to implement the national government's peace agreement with the MILF. Ratification of the law established a new, more autonomous regional government led by the MILF in February. However, some rogue MILF elements and breakaway groups, including BIFF, ASG, AKP, and the Maute Group, continued to oppose the peace process. The Communist Party of the Philippines/New People's Army (CPP/NPA) continued attacks on security forces and civilians, and the government sustained military and law enforcement operations against the group. 
2019 Terrorist Incidents: Terrorists continued to target civilians and security forces with IEDs and small arms, and the emergence of suicide bombings posed new challenges for Philippine security forces.

- An Indonesian couple carried out a complex suicide attack during Mass at the Jolo Cathedral in Sulu on January 27, killing 23 people and wounding 102. Philippine officials linked the plot to the ASG and ISIS, both of which claimed responsibility for the bombing.

- In Sultan Kudarat, the BIFF was implicated in IED attacks on civilian targets that wounded dozens, and a foiled IED attack at a Catholic chapel.

- Two men, including the first Filipino implicated in a suicide bombing, carried out a complex suicide attack against a military unit deployed to combat the ASG in Sulu on June 28, killing eight and wounding at least 20.

- A woman conducted a suicide attack at the entrance to a military camp in Sulu on September 8.

- Security forces thwarted an apparent suicide bombing plot in a November 5 firefight in Sulu, recovering suicide vests from two FTFs killed in the encounter. Terrorist groups abducted Filipino, Malaysian, Indonesian, and British victims.

- Two British citizens were kidnapped in Zamboanga del Sur on October 4 by armed men the government later said were members of ASG. The victims were recovered on November 25 in Sulu following military operations in the area.

Legislation, Law Enforcement, and Border Security: The country's main CT legislation includes the 2007 Human Security Act (HSA) and the 2012 Terrorism Financing Prevention and Suppression Act (TF Law). Proposed amendments to strengthen the HSA by covering preparatory acts and reducing administrative hurdles to terrorism prosecutions remained pending in Congress at the end of 2019. The Philippine government published a list of groups designated as terrorist organizations that included ISIS East Asia and the CPP/NPA. Investments in personnel and training for the Philippine National Police Special Action Force and other specialized law enforcement units improved the government's capacity to detect, deter, and prevent terrorist acts. The government continued law enforcement and judicial responses to terrorism, disrupting plots and investigating and prosecuting terrorists. A regional trial court convicted a Maute Group sniper for violating the Philippine Act on Crimes Against International Humanitarian Law.

The Philippine government made progress toward compliance with UNSCR 2396, taking steps to curb terrorist travel and improving information sharing with foreign partners. The Bureau of Immigration (BI) used deportation and exclusion to remove several FTFs. Although the BI screened against domestic and INTERPOL watchlists at ports of entry, additional capacity is needed to collect API/PNR. The government worked with INTERPOL to enhance collection and reporting of lost and stolen passport information. The Philippines improved aviation security through closer collaboration with foreign partners, with enhanced screening technologies and training, and with strengthened oversight programs and information sharing.

The U.S. Transportation Security Administration (TSA) issued a public notice in December 2018 alerting travelers of deficiencies at Manila International Airport. The government implemented 
improvements, and TSA rescinded the notice in August 2019 after a follow-up assessment showed the airport is now adequately implementing international security standards and recommended practices established by ICAO.

Countering the Financing of Terrorism: The Philippines is a member of the Asia/Pacific Group on Money Laundering (APG), a FATF-style regional body. Its FIU, the Anti-Money Laundering Council (AMLC), is a member of the Egmont Group. The October APG Mutual Evaluation Report noted improvements in technical compliance since 2009, as well as vulnerabilities in light of the Philippines' continued high terrorism-finance-risk profile and mature support networks that sustain terrorist groups. The AMLC announced in November that it had seized \$1 million from terrorism suspects; however, legislative and procedural hurdles continued to impede efforts to prevent, investigate, and prosecute money laundering and terrorism finance. In May, prosecutors used the TF Law to file charges against a suspect for support to the ASG. AMLC increased CFT cooperation with international partners. The Joint Terrorism Financial Investigations Group continued to work with the United States to investigate terrorism finance cases.

Countering Violent Extremism: The Philippines finalized a National Action Plan on Preventing and Countering Violent Extremism and developed and implemented CVE training for security forces and civil servants. Local governments, NGOs, and the private sector partnered on CVE programs. The Philippines established a Country Support Mechanism to coordinate GCERF funding for CVE programs. The Armed Forces of the Philippines worked with local stakeholders to encourage defections from the ASG, BIFF, and the Maute Group, and to rehabilitate former fighters. The Philippine government also supported strategic communications efforts to counter terrorist messaging.

International and Regional Cooperation: The Philippine Navy continued joint patrols with its Indonesian and Malaysian counterparts under a June 2017 trilateral arrangement to combat piracy, terrorism, and the illegal drug trade. Official law enforcement coordination under this mechanism is limited, although the relevant agencies collaborate at the operational level. The Philippines continues to support CT efforts as a member of ASEAN, the ASEAN Regional Forum, and APEC.

\section{SINGAPORE}

Overview: Singapore continued to identify counterterrorism as the nation's top security policy priority and developed a comprehensive CT strategy based on global and regional trends. This strategy included vigilant security measures, regional and international law enforcement cooperation, counter-radicalization efforts, and a campaign to prepare the populace for possible attacks. Singapore was a committed, active, and effective CT partner in 2019. Counterterrorism remained a pillar of the security relationship between Singaporean and U.S. law enforcement and security services. The levels of cooperation on CT efforts and information sharing remained steady in 2019. Singapore's domestic CT apparatus and its ability to detect, deter, and disrupt threats remained effective. Singapore is a member of the Global Coalition to Defeat ISIS.

2019 Terrorist Incidents: There were no terrorist incidents in Singapore in 2019. 
Legislation, Law Enforcement, and Border Security: Singapore uses its Internal Security Act (ISA) to arrest and detain suspected terrorists. The ISA authorizes the Ministry of Home Affairs (MHA), with the consent of the president, to order arrests and detentions without warrants, if it is determined that individuals pose a threat to national security. The initial detention may be for up to two years, and the MHA may renew detention orders for an unlimited period (in increments of up to two years at a time), with the president's consent. Alternatively, the government can issue a restriction order limiting a person's international travel and changes of residence or employment without government approval. ISA cases are subject to review by the courts to ensure strict compliance with procedural requirements under the act. Singapore's existing legal framework, in conjunction with the ISA, provides the government the necessary tools to support the investigation and prosecution of terrorism offenses.

Singapore detained numerous individuals under the ISA for terrorism-related activities in 2019, including a Singaporean who was an alleged supporter of Sri Lankan radical preacher Zahran Hashim, identified by the Sri Lankan authorities as the mastermind of the April 21 terrorist attack in Colombo. Singapore issued detention orders against foreign domestic workers for the first time in 2019, detaining three Indonesian women in September while investigating their terrorism financing activities. Singapore released at least four individuals who were being detained under the ISA after assessing their rehabilitation progress and determining that the individuals no longer posed a security threat that required preventive detention.

Singapore maintains a "not if, but when" stance regarding the likelihood of terrorist attacks within the city-state. The government's SGSecure public awareness campaign, started in 2016 to improve emergency preparedness, promote security awareness, and build national resiliency, launched a "SGSecure Roadshow" program in August to bring interactive and informational tools on emergency preparedness directly to communities. Roadshows will be held in shopping malls and town centers throughout the country. The Singapore Police Force and Singapore Civil Defense Force continued regular CT exercises in 2019, including conducting simulated terrorist attacks in a place of worship and a concert setting for the first time. The MHA launched the Home Team Science and Technology Agency in December with a mandate to develop science and technology capabilities to enhance Singapore's ability to address emerging threats and evolving challenges on the security landscape.

To better detect possible terrorist movements by air into or transiting through the country, Singapore's primary border security agency, the Immigration and Checkpoints Authority, is working to improve its passenger screening system by integrating API/PNR data transmitted from air carriers into its border screening processes.

Countering the Financing of Terrorism: Singapore has maintained an Anti-Money Laundering and Countering the Financing of Terrorism Industry Partnership (ACIP) since 2017. The ACIP is a joint initiative between the Monetary Authority of Singapore and the Commercial Affairs Department of the Singapore Police Force, with the goal of bringing together relevant government agencies and private-sector participants to strengthen Singapore's capabilities to combat money laundering and terrorist financing. In April, Singapore's "Serious Crimes and Counter-Terrorism (Miscellaneous Amendments) Act" went into effect, strengthening AML and 
CFT frameworks. The law updated the Terrorism (Suppression of Financing) Act to expand the scope of prohibited activities to include financing travel for terrorist training and increase penalties for terrorism financing. The law also allowed Singapore's FIU, the Suspicious Transaction Report Office, to exchange financial intelligence with FIUs in a broader range of overseas jurisdictions. Singapore convicted and sentenced the first Singaporean national under the Terrorism (Suppression of Financing) Act in October. The accused was sentenced to 30 months in jail for providing approximately $\$ 1,000$ to an individual overseas who was facilitating terrorist acts.

Countering Violent Extremism: Through entities such as the International Centre for Political Violence and Terrorism Research (ICPVTR) and the Religious Rehabilitation Group (RRG), Singapore serves as a regional CVE hub. The ICPVTR conducts research, training, and outreach programs aimed at understanding the causes of "extremism" and formulating practical rehabilitation programs. The government also encourages inter-religious and inter-ethnic dialogue through Interracial and Religious Confidence Circles and the inter-agency Aftercare Group, local community fora that bring leaders from Singapore's religious and ethnic communities together to discuss issues of concern and build trust.

The government believes in building regional CVE capacity, and has highlighted opportunities for constructive engagement for those concerned with the conflict in Syria and Iraq, such as promoting legitimate charities working to ease suffering in conflict zones. The Islamic Religious Council of Singapore (MUIS), the Islamic authority in charge of Muslim affairs, maintains a Facebook presence and holds outreach and educational events to counter terrorist propaganda and recruitment efforts. MUIS manages the Asatizah Recognition Scheme that vets Islamic Religious Council teachers and scholars in Singapore.

Singapore's RRG, a volunteer organization made up of Islamic scholars and teachers, has had success in counseling detainees held under the ISA. The comprehensive program includes religious and psychological counseling and involves the detainee's family and community. The RRG also operated a resource and counseling center for the Muslim community and held community events, such as a documentary screening and dialogue with foreign domestic workers in Singapore, to discuss religious concepts and indicators of radicalization.

International and Regional Cooperation: Singapore is an active participant in CT cooperation efforts in ASEAN, the ASEAN Regional Forum, and APEC. Singapore is a strong advocate for the ASEAN "Our Eyes" regional initiative, which strives for ministerial-level CT information sharing. Singapore remains interested in improving regional CT information sharing at the operational level as well. In October, Singapore and Jordan co-hosted the "Aqaba Process" Southeast Asia Expert-Level Meeting. Singapore attended the Fifth Counter-Terrorism Financing (CTF) Summit 2019 held in November 2019 in Manila, Philippines, and contributes actively to a number of information sharing projects under the CTF Summit's South East Asia Counter-Terrorism Financing Working Group. 


\section{THAILAND}

Overview: Thailand experienced no attacks attributed to transnational terrorist groups in 2019 and violence was restricted to attacks attributed to ethno-nationalist insurgents in the country's restive southern region. The number of terrorist incidents in the Deep South (the southernmost provinces of Pattani, Yala, Narathiwat, and parts of Songkhla) in 2019 was the lowest since the conflict reignited in 2004. Thai security officials remain concerned about the potential for ISIS to infiltrate domestic insurgent groups, although they have maintained that there is no evidence to date of any operational linkages between these domestic groups and international terrorism networks. Thailand's principal vulnerability to international terrorism continues to be as a transit and facilitation hub, given the high volume of travelers through Bangkok's main airport and available market of illegal goods. Thailand remained a productive CT partner, though the Thai government continues to focus on domestic political challenges as its primary security priority.

2019 Terrorist Incidents: Overall, the number of insurgent terrorist attacks and related fatalities decreased from the previous year; however, a November 5 attack at a security checkpoint in Yala killed 15, making it the single deadliest attack attributed to southern insurgents since 2004. Attacks in 2019 were primarily confined to Thailand's southernmost provinces, although a set of coordinated small-scale explosions in Bangkok in August is widely believed to be linked to the Deep South insurgency. Terrorist methods primarily included shootings, arson, IEDs, and VBIEDs.

- In January, a spate of terrorist attacks took place, including a car bomb outside a security base in Songkhla Province that wounded two police officers, the shooting death of four defense volunteers guarding a school in Pattani Province, and an attack on a police station in Narathiwat Province that killed one police officer.

- On January 18, two Buddhist monks were killed in an insurgent attack in Narathiwat Province, the first monks killed in an insurgent attack in three years. The attack followed the killing of three imams by unknown assailants in the preceding two months.

- During March 9-10, a series of homemade pipe bombs exploded in the southern provinces of Satun and Phattalung but they caused no deaths or injuries. Both provinces border the Deep South, but neither has a history of insurgent-related activity.

- On May 26, a bomb attack on a railway station in Songkhla Province killed one police officer and injured three others.

- On May 27, at least two people died and nine were injured when a motorcycle bomb exploded at a flea market in Pattani Province.

- On August 2, a series of coordinated small-scale explosions took place across Bangkok as the city hosted more than 30 Foreign Ministers for the ASEAN Ministerial and related meetings. The small improvised bombs caused no severe injuries or damage. Although there has been no official attribution or claim of responsibility, most Deep South experts claim it was likely linked to the insurgency. Three suspects were arraigned in November on 11 charges related to the August bombings in Bangkok, including terrorism. The case is currently in pre-trial examination and the trial is scheduled to start in September 2020. 
- On November 5, 15 people were killed and another four wounded in a late-night attack at a checkpoint in Yala Province targeting police, government officials, and local security volunteers in what was the deadliest attack since violence resurfaced in 2004. An estimated 10 to 20 assailants used small arms and bombs in the attack. Although no group claimed responsibility, the attack has been attributed to the Barisan Revolusi Nasional separatist group.

Legislation, Law Enforcement, and Border Security: Thailand is in the process of drafting a new Counterterrorism Act, which aims to integrate existing terrorism-related laws into one document. Thailand continues to apply the 2017-2021 National Counterterrorism Strategy for the prevention of and response to terrorist attacks, but details of the strategy have not been made public. Under the strategy, the Ministry of Foreign Affairs maintains plans for collaboration with foreign governments.

Thailand's law enforcement authorities demonstrated some capacity to detect, deter, and respond to terrorist incidents. Multiple entities including the Royal Thai Police, the Department of Special Investigation, and components of the Thai military have law enforcement responsibilities on CT cases. Interagency cooperation and coordination were sporadic, information sharing was limited, and the delineation of duties between law enforcement and military units with CT responsibilities was unclear.

Thailand's borders are relatively porous, and information sharing within Thailand and with neighboring countries is limited. The market in fraudulent documents remained active despite government efforts to crack down on criminal counterfeit networks. Beginning in 2016, Thailand began to collect and analyze API/PNR data on commercial flights at all international airports. As of late 2018, Thailand's immigration system is reported to be real-time connected with INTERPOL's Stolen and Lost Travel Document Database.

Countering the Financing of Terrorism: Thailand belongs to the Asia/Pacific Group on Money Laundering, a FATF-style regional body. Thailand's FIU, the Anti-Money Laundering Office, is a member of the Egmont Group. There were no significant updates in 2019.

Countering Violent Extremism: The national CT strategy published in 2017 includes a CVE component. Thailand lacks a national CVE action plan, but the National Security Policy and Plan (2019-2022) published in November 2019 includes regionally specific security plans that focus on "extremism."

International and Regional Cooperation: Thailand is a member of ASEAN, EAS, ARF, and APEC, and participated in international CT efforts, including through ASEAN, APEC, and ARF. 


\section{EUROPE}

\section{Overview}

Europe continued to face many ongoing terrorist threats and concerns in 2019, including from U.S.-designated FTOs, FTFs returning from Iraq and Syria, homegrown terrorists, and Iranbacked terrorists. Despite the total loss of its geographic territory, ISIS continued to project its influence by fomenting attacks against symbolic European targets and public spaces, and recruiting from European countries. Most of these incidents occurred in Western Europe and Russia and involved simple plots with easily executable tactics, such as the use of common tools and vehicles to injure or kill pedestrians.

Many FTFs from Europe remained in the custody of the Syrian Democratic Forces (SDF) in northeast Syria at the end of 2019. The United States urged European and other countries to bring back their citizens and prosecute, rehabilitate, and reintegrate them as appropriate, as the United States has done. However, with the notable exceptions of Ireland and Italy, Western European governments generally refused to repatriate and prosecute their citizens, despite having extensive resources and well developed judicial systems. A number of Western European countries revoked the citizenship of certain citizens who traveled to Syria or Iraq to join ISIS. Countries in southeast Europe, including Kosovo and Bosnia and Herzegovina, successfully repatriated numerous ISIS-affiliated citizens, including FTFs. The SDF lacks the resources, capacity, and support to detain ISIS fighters and family members for the long term.

In Turkey, terrorist groups espousing a range of extremist and nationalist ideologies, such as the Kurdistan Workers' Party (PKK) and the Revolutionary People's Liberation Party/Front, continued to plot against police and military targets in Turkey and raise funds throughout the rest of Europe. Many European countries also saw a rise in racially or ethnically motivated terrorist (REMT) activity and plotting, including against religious and other minorities.

Several European countries took concrete steps to combat Iranian regime-backed terrorism in 2019. Albania, Denmark, and France all reduced diplomatic relations in response to Iran-backed plots to conduct assassinations or bombings in those countries. These plots in the heart of Europe illustrate the global reach of Tehran's terrorist capabilities. In response to Iran's terrorist plotting in Europe, the United States in 2019 launched the Countering Transnational Terrorism Forum (CTTF), bringing together law enforcement officials, prosecutors, and financial practitioners from more than 25 countries to disrupt Iranian terrorist activities and networks. Numerous European nations also continued to participate in the U.S.-Europol Law Enforcement Coordination Group (LECG) to counter Hizballah's terrorist and illicit activities around the world. The LECG met twice in 2019.

Many European governments are increasingly concerned about the threat posed by REMT. A deadly October 2019 attempted attack targeting a synagogue in Halle, Germany, demonstrated the continued danger posed by REMT actors who exploit the internet and social media to spread violent propaganda. A number of European governments expanded law enforcement and other government efforts to combat the threat posed by REMT individuals and groups. 
European countries were integral to worldwide counterterrorism efforts in 2019. Thirty-nine European countries, the EU, INTERPOL, and NATO were active in the Global Coalition to Defeat ISIS. In December, NATO Allies endorsed an update to the NATO Counterterrorism Action Plan, which includes efforts to increase resilience, expand cooperation with NATO partners and international organizations, and improve information sharing. The Counterterrorism Action Plan continues to support the Resolute Support Mission in Afghanistan, the Global Coalition to Defeat ISIS, and NATO Mission Iraq.

\section{ALBANIA}

Overview: Albania continued its strong support of international CT efforts in 2019 and contributed to the Global Coalition to Defeat ISIS. The terrorism threat in Albania consists of FTFs returning from Iraq and Syria, Albanian youth being radicalized to terrorism, and Iran's plotting against the resettled Iranian opposition group Mujahedeen-e-Khalq (MEK).

2019 Terrorist Incidents: There were no reported terrorist incidents in Albania in 2019.

Legislation, Law Enforcement, and Border Security: Albania has criminalized terrorist acts, the financing of terrorism, conducting transactions with persons on UN sanctions lists, recruiting and training people to commit terrorist acts, the incitement of terrorist acts, and establishing, leading, and participating in terrorist organizations or armed conflicts outside the country. Albania sustains a port security oversight system to comply with requirements under the International Maritime Organization's International Ship and Port Facility Security Code.

Albanian law enforcement increased efforts to counter potential terrorist threats. The Albanian State Police Counterterrorism Unit (CTU) worked closely with U.S. agencies to align Albanian government requirements with U.S. expertise and resources, ensuring the Albanian government develops focused CT capabilities. The CTU also participated in several successful interdictions of known or suspected terrorists. In 2019, the CTU created a small sub-unit focused on countering terrorism financing. The Albanian government has developed, in conjunction with international partners, contingency plans and capabilities to prevent and respond to terrorist attacks against soft targets. On October 23, the Albanian State Police announced it had foiled attacks planned in 2018 by Iranian agents against MEK members living in Albania.

Corruption and barriers to information sharing among government agencies, insufficient intraagency coordination, and a poorly functioning judicial system continued to hinder Albania's law enforcement efforts at all levels. Implementation of deep reforms in the judicial sector continues, beginning with the vetting of Albania's 800 judges and prosecutors for corruption, incompetence, and ties to organized crime. Once Albania establishes the Special AntiCorruption and Organized Crime Structure (SPAK), jurisdiction over terrorism cases involving an organized group will fall under the SPAK's purview. District prosecution offices will prosecute all other CT cases. 
Albania continues to take steps to enhance its border security, to detect and deny entry to terrorists, and comply with UNSCR 2396 standards such as the use of API/PNR to improve screening of air passengers. Law enforcement services cooperate extensively with INTERPOL and other international law enforcement bodies.

Countering the Financing of Terrorism: Albania is a member of the Committee of Experts on the Evaluation of Anti-Money Laundering Measures (MONEYVAL), a FATF-style regional body. Its FIU, the General Directorate for the Prevention of Money Laundering, is a member of the Egmont Group.

In 2019, Albania continued to work with FATF and MONEYVAL to address identified weaknesses in its AML/CFT regime. A July 2018 MONEYVAL evaluation reported that Albania had "low effectiveness" in three immediate outcome areas: confiscation, terrorist finance investigation and prosecution, and proliferation finance sanctions. In June 2019, Albania enacted legislation to address these concerns, but actual implementation hinges on further regulations and action by the government.

Also in 2019, the OSCE and UNODC jointly held a train-the-trainer course on countering terrorist financing for participants from Albania. The course was part of a multi-annual OSCEUNODC capacity-building program to support national efforts to counter terrorist financing in South-Eastern Europe, in accordance with UN Security Resolution 2462, FATF standards, and OSCE commitments.

Countering Violent Extremism: The Government of Albania's National CVE Center remains active in coordinating CVE programming among international donors and seeks to ensure all ministries cooperate effectively and avoid duplication of effort. The Albanian cities of Cerrik, Elbasan, Librazhd, and Tirana are members of the Strong Cities Network (SCN). The Albanian State Police have incorporated countering terrorist radicalization and recruitment into the portfolios of 26 community police units around the country. The chiefs of these units received training from the U.S. government and implemented projects with local government counterparts to detect and counter terrorist radicalization efforts.

International and Regional Cooperation: Albania is a member of the Adriatic Charter, the Council of Europe (CoE), NATO, the Organization of Islamic Cooperation, the OSCE, the Regional Cooperation Council for Southeast Europe, and the UN. Albanian criminal-justice officials participated regularly in various regional associations, conferences, and other CT information-sharing exchanges.

\section{AUSTRIA}

Overview: U.S.-Austrian law enforcement cooperation remained strong. Parliament ended its ad-hoc probe of the Federal Office for the Protection of the Constitution and Counterterrorism (BVT), Austria's key counterterrorism agency within the Ministry of the Interior. The parliamentary inquiry exposed internal weaknesses and the need for restructuring, which an independent commission began in August 2019. Austria's CT efforts focused on "Islamist extremism," the potential for homegrown terrorism by "lone actors," and REMT groups 
promoting anti-Muslim and anti-migrant violence (which Austria refers to as "New Right" groups). Austrian courts continued to impose strong sentences for convicted Islamist terrorists. Austria expanded its national action plan for the "prevention of extremism and deradicalization," and legislators called for better staffing of the BVT's extremism section.

The BVT monitors an estimated 94 persons who returned to Austria from conflict zones, and the Interior Ministry estimated at the end of 2018 more than 100 Austrian FTFs were still in Syria and Iraq. Overall, the BVT noted that terrorist mobilization substantially declined after 2015.

Austria is a member of the Global Coalition to Defeat ISIS and a member of the Coalition's Foreign Terrorist Fighters and Stabilization working groups. Law enforcement agencies focused on intelligence gathering and investigations, as well as on sharing information with international partners.

2019 Terrorist Incidents: There were no reported terrorist incidents in Austria in 2019.

Legislation, Law Enforcement, and Border Security: Austria has an extensive legal structure to counter terrorism. Relevant statutes criminalize training in terrorist camps abroad and allow wiretapping of individual suspects or small groups with the permission of an independent judge or ombudsman. Specific regulations prohibit the use and distribution of symbols attributable to ISIS or al-Qa'ida. An amendment passed in December 2018 to the Symbol Act took effect in February 2019, criminalizing the display of symbols related to the Muslim Brotherhood, Hamas, the Grey Wolves, the PKK, and the Croatian Ustasha.

As of 2019, all mobile airtime cards must be registered. Additional legislation regulates use of International Mobile Subscriber Identity catchers - telephone eavesdropping devices that allow localization of mobile phones without contacting mobile operators. The Constitutional Court in 2019 declared a law on surveillance unconstitutional on privacy grounds before it took effect. The law would have allowed authorities to tap messenger services such as WhatsApp and Skype in cases of suspected terrorism with a court order.

Austrian law enforcement and BVT officials routinely cooperated with U.S. law enforcement in a range of areas, including joint investigative projects and enforcement operations.

Austria has taken a whole-of-government approach to implement UNSCRs related to CT and the GCTF's Good Practices on Addressing the Challenge of Returning Families of FTFs. Austrian law criminalizes "travel for terrorism purposes" with sentences of six months to five years in prison, extends domestic jurisdiction to individuals in Austria who committed a crime abroad, and ensures legal counsel for terror victims. This law implements the EU Directive on Combating Terrorism and the UN's International Convention for the Suppression of the Financing of Terrorism.

In 2019, Austria extended temporary border checks with its Schengen neighbor countries, introduced in 2016, and continued to deploy more than 800 soldiers at its eastern borders. Regulations allow border authorities to prevent minors from leaving Austria upon suspicion they will participate in fighting activities abroad. Border security forces made 
effective use of security measures, including biographic and biometric screening capabilities at ports of entry and information sharing internally and with other EU countries. In 2019, the Austrian Army and the U.S. National Guard began exchanging best practices in border protection as part of a partnership that also includes training for Austrian and U.S. noncommissioned officers in both countries.

Austria has rigorous processes in place to register and screen individuals applying for asylum, lawful residence, and citizenship. Authorities are allowed to confiscate up to 840 euros from asylum seekers to cover costs related to the asylum proceedings and to analyze their phones and storage devices to obtain data on the routes traveled. Authorities check applicants' fingerprints against the EU's asylum fingerprint database (Eurodac) and, in select cases, against criminal databases. Authorities screen individuals against national and international law enforcement databases before citizenship is approved.

Vienna CT squads arrested and charged two suspects in December for planning terrorist attacks in Austria, Germany, and Luxembourg, together with an imprisoned ISIS sympathizer.

Countering the Financing of Terrorism: Austria is a member of the FATF. Its FIU, the Austrian Financial Intelligence Unit, is a member of the Egmont Group. There were no significant updates in 2019.

Countering Violent Extremism: Austria continued its CVE efforts largely in response to the FTF phenomenon. The Austrian Ministry of Foreign Affairs (MFA) worked with the Islamic Faith Community to conduct an information campaign in mosques, Islamic organizations, community centers, and prisons. To counter "extremism" and improve integration among newly arrived refugees, the MFA's Integration Office conducted an educational program to teach German language and Austrian values such as equality and democratic principles. In addition, the Austrian government expanded its draft action plan to implement terrorist prevention policies laid out in a national strategy. This includes a comprehensive "exit program" for radicalized youth. The Austrian government maintained a counseling center and a de-radicalization hotline aimed at friends and family members of potential terrorists. The Ministry of Justice presented measures aimed at "extremist prevention, deradicalization, and disengagement" among Austria's prison population.

The U.S. Embassy to Austria and the Department of State's Counterterrorism Bureau co-hosted a CVE workshop to exchange best practices across the region. CT Bureau sent a former white supremacist to Austria to provide authentic testimonials about the destructive nature of terrorism and hate.

International and Regional Cooperation: Austria is a member of international and regional security platforms, including the UN, the CoE, the EU, the OSCE, the Salzburg Forum, and the Central European Initiative. Austria remained active in the Western Balkans Counter Terrorism Initiative, a platform it initiated in 2015. Austria participates in Eurojust's EU-wide terrorism register, which lists all ongoing terrorism investigations of individual EU member states. 
In 2019 the European Commission initiated infringement proceedings against Austria (and Bulgaria, Romania, and Hungary) for their 2018 agreement with Western Balkans countries to streamline certain information sharing, including in terrorism cases.

\section{AZERBAIJAN}

Overview: In 2019, the Azerbaijani government actively worked to deter, detect, and defeat terrorist efforts to move people, money, and materials across its land and maritime borders and within the South Caucasus. Azerbaijani law enforcement and security services conducted operations to disrupt and prevent terror attacks, arrested and prosecuted suspected terrorists, and prosecuted returning Azerbaijanis suspected of joining or financing terrorist groups fighting outside Azerbaijan.

2019 Terrorist Incidents: There were no reported terrorist incidents in Azerbaijan in 2019.

Legislation, Law Enforcement, and Border Security: In 2019, Azerbaijan made no significant changes to the legislation on combating terrorism.

Azerbaijani law enforcement and security services have demonstrated adequate capacity to detect, deter, and prevent acts of terrorism in Azerbaijan's territory. Responsibility for Counterterrorism is vested in several government agencies. The Ministry of Internal Affairs (MIA) is Azerbaijan's primary law enforcement agency, and its Organized Crime Unit is tasked with leading the Ministry's CT efforts. The MIA cooperates closely with the State Security Service (SSS), Azerbaijan's domestic intelligence and CT service. The SSS is responsible for identifying and preventing criminal activities by terrorist groups and countering international terrorism and transnational crimes. Law enforcement and security agencies continued to exhibit wide discretion in determining what activities qualify as "terrorism" or "extremism," leaving political opponents and religious activists vulnerable to prosecution, detention, and physical mistreatment. Such individuals have been especially vulnerable to physical abuse by the MIA's organized crime unit. For further information, see the Department of State's Country Reports on Human Rights Practices and International Religious Freedom Report.

The Special State Protection Service is a security agency under the Presidential Administration tasked with protecting the Azerbaijani president, visiting foreign heads of state and government, and critical infrastructure and strategic state resources, such as oil and gas pipelines. The State Border Service (SBS) and the State Customs Committee jointly manage border security, and interdict terrorist efforts to move people, money, and materials - including weapons of mass destruction - across Azerbaijan's land and maritime borders. The SBS is also responsible for defending offshore oil platforms against terrorism. The Prosecutor General's Office is responsible for prosecuting suspects accused of terrorism, conspiracy to commit terrorism, conspiracy to aid terrorism, and other terrorism-related crimes.

Azerbaijan used terrorist and criminal watchlists and biographic/biometric screening at ports of entry. Azerbaijan's law enforcement and security services share information among themselves, and with regional and international partners regarding terrorism matters. 
Countering the Financing of Terrorism: Azerbaijan is a member of MONEYVAL. Its FIU, the Financial Monitoring Service, is a member of the Egmont Group. In 2019, Azerbaijan continued implementing its "National Action Plan for 2017-2019 on combating criminally acquired money, legalization of other properties, and financing of terrorism."

Countering Violent Extremism: The State Committee for Work with Religious Organizations announced in April it is jointly developing with the Ministry of Education and the Caucasus Muslim Board a religion course that will be included in the curriculum of public middle schools and public universities in Azerbaijan as early as September 2020. According to the Committee, the course would promote the state's "secular policy and help counter the spread of radical and fundamentalist movements."

International and Regional Cooperation: Azerbaijan maintained membership in the $\mathrm{CoE}$, the OSCE, the Organization of Islamic Cooperation, and other international bodies. Azerbaijan supports NATO CT initiatives as one of the Alliance's Partnership for Peace countries. Azerbaijan participated in NATO's Resolute Support Mission in Afghanistan, where it deployed 120 peacekeeping troops, and contributed to the Afghan National Army Trust Fund.

\section{BELGIUM}

Overview: Belgium continues to make incremental improvements to CT-related policy, information-sharing practices, and resource allotments, which have enhanced authorities' abilities to investigate and prevent terrorist attacks. Belgium actively shares terrorist and criminal information with the United States under the Visa Waiver Program. However, Belgium's highly decentralized government presents challenges to effective internal information sharing and cooperation, and the caretaker status of Belgium's government throughout 2019 hampered its ability to make meaningful policy advancements. Belgian law enforcement authorities remain under-resourced. The Belgian criminal code's short sentencing guidelines limit the criminal justice system's ability to deter and prevent terrorist activity. The country's greatest terrorism threat is homegrown terrorism, including both Islamist extremism and, to a lesser extent, REMT, which Belgium calls "violent right-wing extremism." Belgium is a member of the Global Coalition to Defeat ISIS and plans to resume contributing troops and airstrike capabilities to the Defeat ISIS military campaign in 2020.

Terrorist Incidents: There were no terrorist attacks in Belgium during 2019. However, security forces interrupted a small number of attacks in the planning stages and also intervened with persons providing material support to terrorists. The following list provides a sampling of successful interventions:

- On January 24, police arrested three individuals (in Bruges, Leuven, and Molenbeek) on suspicion of participation in terrorist activities. After releasing the individual from Leuven, prosecutors charged the remaining two in October with funding a terrorist group.

- On March 15, the Belgian Federal Police arrested an individual who had anonymously placed an online threat against the Antwerp Central train station in retaliation for the March 2019 New Zealand mosque attacks. 
- On June 22, police arrested Matthew Govaert in Brussels for plotting an attack against the U.S. Embassy in Brussels.

Legislation, Law Enforcement, and Border Security: Belgium's primary CT-related actors include the Belgian Federal Police, the civilian and military security and intelligence services, and the Office of the Federal Prosecutor. The Ministry of Interior maintains a Crisis Center. The interagency Coordination Unit for Threat Analysis, consisting of representatives from the ministries of Interior, Justice Finance, Treasury, and Transport, as well as the security sector, assesses and sets country-wide threat level ratings and maintains Belgium's database of foreign fighters, hate preachers, and homegrown terrorists. The National Security Council also plays a significant role in intelligence and security decisions. Belgium's highly devolved government structure presents challenges to effective internal communication and cooperation between Belgium's numerous law enforcement and criminal justice entities. Government-wide resource constraints impair Belgium's ability to proactively detect, deter, and prevent acts of terrorism. As of December 2019, Belgium had failed to fully implement July 2018 amendments to its criminal code allowing the use of civil information. Belgium's short prison sentences continued to reduce the efficacy of an amendment in 2018 allowing plea bargaining. Belgium implemented the EU PNR directive for airport travelers through the establishment of the Belgian Passenger Information Unit in early 2018 and has continued, throughout 2019, to integrate additional airline companies and to test practical implications for adding PNR analytic capabilities on additional transport modes, such as international rail and bus systems. In 2019, Belgium held the chair of Europol's Informal Working Group on PNR, hosting meetings that resulted in proposals to carry PNR forward Europe-wide.

Countering the Financing of Terrorism: Belgium is a member of the FATF. Its FIU, the Belgian Financial Intelligence Processing Unit, is a member of the Egmont Group. Belgium is also a member of the Defeat ISIS Coalition's Counter-ISIS Finance Group (CIFG). On September 12, 2019, a Belgian court sentenced Amadou Mugabo to 100 hours of community service and fines for financial support of terrorism after it was uncovered that he was sending funds to a known FTF in Syria or Iraq.

Countering Violent Extremism: Belgium's federal, regional, and local governments remained engaged in CVE efforts through 2019, despite ongoing institutional and resource constraints. Local task forces constituted in 2014 and expanded in 2018 continue to meet to coordinate CVE responses among local security, municipal, and social services personnel, a key recommendation of the Parliamentary Investigative Commission's final report on the March 22, 2016, terrorist attacks in Brussels. In March, after negotiations between the two countries, Saudi Arabia relinquished control of the Brussels Grand Mosque in alignment with the Parliamentary Investigative Commission's finding that Saudi Arabia's Muslim World League was partially responsible for the Islamist extremism that motivated the perpetrators of the 2016 attacks in Belgium. In December, Belgium's prison population included at least 227 persons jailed for links to ISIS or al-Qa'ida. Prisoners charged or convicted with terrorism-related offenses were generally transferred to prisons with segregated sections for radicalized inmates, though many become eligible for parole upon completing one third to two thirds of a typical five-year sentence. Prisoner rehabilitation resources remained minimal, and regional governments continued to struggle to fill vacancies for positions with CVE responsibilities. The Belgian cities 
of Antwerp and Vilvoorde are members of the SCN, and city officials from Antwerp traveled to San Diego and Los Angeles as part of the program in October. In November, Belgian officials from Liege and Verviers traveled to the United States to exchange best practices on preventing and countering terrorism with officials from Nashville and Chattanooga, Tennessee, under the City-Pair Program.

International and Regional Cooperation: Belgium participates in CT efforts with the EU, NATO, the OSCE, and CoE, and Belgium is a member of the advisory board of the UN Counterterrorism Center. Belgium's Michèle Coninsx remained Executive Director of the UN Counterterrorism Executive Directorate throughout 2019. Belgium used its nonpermanent seat in the UN Security Council (UNSC) during 2019 to promote prison deradicalization and awareness of the humanitarian consequences of counterterror actions. Belgium is also an active contributor to the subcommittees of the UNSC that deal with counterterror. Belgium is a troopcontributing member of the European Union Training Mission in Mali. Belgium is also a troopcontributing member of the UN Multidimensional Integrated Stabilization Mission in Mali. Belgium participated in all EU efforts to interdict FTF travel across land and maritime borders, encouraged efforts to strengthen Schengen zone external borders, and maintained a leading role in the European Strategic Communication Network.

\section{BOSNIA AND HERZEGOVINA}

Overview: Bosnia and Herzegovina $(\mathrm{BiH})$ remained a cooperative counterterrorism partner and continued to increase its CT capacity in 2019. There were no known registered BiH citizens who attempted to travel to foreign battlefields in 2019, although dozens remain in Iraq, Syria, and Ukraine, and $\mathrm{BiH}$ continues to face the threat of returning fighters. $\mathrm{BiH}$ continues to be a willing partner in repatriation of FTFs, and the BiH Presidency agreed in November 2019 to repatriate some family members of FTFs from Syria. Seventeen women and children were repatriated, along with seven fighters, in December 2019. BiH law enforcement agencies have been very cooperative on this effort. Lenient sentencing in terrorism cases remained a challenge, but recent judgments indicate some judges recognize a need to apply more rigid sanctions. Operational coordination continues internally in $\mathrm{BiH}$ and with U.S. partners. However, interpersonal and interagency infighting and stove piping undermine fully effective cooperation, especially due to a lack of strategic guidance from the Ministry of Security. While little progress was made on rehabilitation and de-radicalization, diverse civil society groups, the Interreligious Council, and individual religious leaders made notable efforts to prevent and counter terrorist radicalization and recruitment.

Terrorist Incidents: There were no reported terrorist incidents in $\mathrm{BiH}$ in 2019.

Legislation, Law Enforcement, and Border Security: BiH made no significant changes to its CT legislation in 2019. A group of parliamentarians proposed draft amendments to further align $\mathrm{BiH}$ law with EU directives on the suppression of terrorism and to introduce three new crimes to the $\mathrm{BiH}$ criminal code in 2018, but general elections in October 2018 and slow government formation delayed progress. The amendments would criminalize traveling and residing abroad for terrorism, misusing information technology or cyber technology for terrorist purposes, and forging documents for the purposes of terrorism. The draft amendments also strengthen an 
existing criminal code provision on training for terrorist activities. Although the amendments again need to be submitted to Parliament, there is some political will to adopt them.

The State Investigation and Protection Agency (SIPA) continues to be the lead law enforcement unit performing CT functions. However, with approximately 25 officers working on CT cases, its effectiveness is limited, and there were no political efforts in 2019 to increase the size of SIPA's counterterrorism unit, despite a draft law pending in Parliament since 2017. As an alternative to changes to the law, SIPA recently considered a change to its internal by-laws to increase the number of officers. SIPA continues to receive training funded by the U.S. Department of State's ATA program to ensure that key units can effectively investigate terrorism-related crimes.

A BiH Prosecutor's Office-led task force met more frequently in 2019, but law enforcement cooperation at a more strategic level continued to suffer from some interpersonal and institutional infighting, as well as BiH's complex governmental structure. At the operational level, however, law enforcement and prosecutors met and worked jointly on certain cases. Law enforcement agencies also worked effectively together on responding to returning fighters, and their family members from Syria, although the Ministry of Security did not have a comprehensive plan for reintegrating and rehabilitating family members.

There is a lack of political will to implement U.S.-funded initiatives, despite a desire from $\mathrm{BiH}$ law enforcement to have these tools. The Presidency of BiH did not move to approve a proposal to support use of API/PNR as part of its integrated border management and in line with UNSCR 2396. There was some progress on border security initiatives, as the Border Police continued to implement upgrades to technology at key points of entry and the Foreigners' Affairs Service worked proactively with international partners to exchange information on the continually higher number of migrants entering $\mathrm{BiH}$.

$\mathrm{BiH}$ continued its efforts to disrupt terrorist activity in 2019 through arrests and indictments. In November, the Court of $\mathrm{BiH}$ increased the sentences for Maksim Božić and Edin Hastor to six years (from four years) and three years (from two years, six months) of imprisonment for planning terrorist acts, respectively; this was a final verdict and is considered high for $\mathrm{BiH}$. $\mathrm{BiH}$ also began to prosecute its citizens for joining foreign paramilitary forces under the same provision it uses to prosecute people who join ISIS.

Countering the Financing of Terrorism: $\mathrm{BiH}$ is a member of MONEYVAL. Its FIU, the Financial Intelligence Department, is a member of the Egmont Group. In 2019, in line with UNSCR 1373, the BiH Council of Ministers designated Mirsad Kandić for asset freezing.

Countering Violent Extremism: "Extremist ideology and regional nationalist" groups remain potential sources of terrorism in $\mathrm{BiH}$. In 2019, the main religious communities in $\mathrm{BiH}$ (Catholic, Islamic, Jewish, and Orthodox) worked together through the Interreligious Council to promote tolerance and confront acts of bigotry or violence directed at any of these communities. The Interreligious Council also increased its coordination and activities with its 15 regional chapters, with an emphasis on increasing engagement with women and youth - through social media campaigns and other strategies. Individual religious leaders and civil society groups (formal and 
informal) across the country also made increasing efforts to identify "extremist influences" and sources of resiliency in their communities, supported by a range of international donors and organizations. International and local actors working on countering terrorist radicalization and recruitment made significant efforts in broadening their analysis beyond radical Islam to include extreme ethno-nationalism and foreign influence, as well as domestic drivers of "extreme ideologies."

The BiH Ministry of Security partnered with the international community on numerous CVE programs in $\mathrm{BiH}$. Working with international organizations, $\mathrm{BiH}$ supported efforts to strengthen resiliencies within identified at-risk communities, and it supported efforts by religious and other local actors to counter expressions of intolerance at the local and municipal levels. The $\mathrm{BiH}$ cities of Bihać, Bijeljina, Doboj, Jablanica, Prijedor, Srebrenik, and Tuzla Canton - and the municipality of Centar (Sarajevo) - are members of the SCN. There are insufficient mechanisms to measure progress and implementation of BiH's CT/CVE Strategy.

In 2019, the OSCE presented in Sarajevo its publication on "referral mechanisms for preventing and countering violent extremism and radicalization that lead to terrorism." The publication enabled a multidisciplinary, human-rights-compliant, and regionally tailored approach to the identification of those at risk of engaging in violent acts.

International and Regional Cooperation: The BiH Prosecutor's Office continues to work frequently with the United States, regional neighbors, Serbia and Montenegro, and EU countries such as Austria, Germany, and the UK on CT investigations. $\mathrm{BiH}$ is a member of or participating state in the UN, the OSCE, the Regional Cooperation Council for Southeast Europe, and the Council of Europe $(\mathrm{CoE})$.

\section{BULGARIA}

Overview: Bulgaria remains a strong counterterrorism partner of the United States. While the threat of terrorism in Bulgaria remains relatively low, the government has continued its CT capacity building, including through close and ongoing cooperation with U.S. government agencies, though some capability gaps remain. Given Bulgaria's strategic location, many of these efforts have focused on disrupting the transit of FTFs through enhanced border security, traveler screening, and information sharing. Bulgaria is a member of the Global Coalition to Defeat ISIS.

2019 Terrorist Incidents: There were no terrorist incidents reported in Bulgaria.

Legislation, Law Enforcement, and Border Security: Bulgaria prosecutes terrorism under several general provisions of the penal code, which has been amended multiple times since it was first enacted in 1968. In 2015, the National Assembly adopted amendments to the penal code that provide for the prosecution of individuals, including FTFs, who support, plan, and facilitate the commission of terrorist acts in Bulgaria and abroad. Since 2017, the specialized court for organized crime and its prosecutors' office have had jurisdiction to prosecute all terrorism cases in the country. 
The Ministry of the Interior has operational units responsible for deterring, detecting, and responding to terrorist incidents, including the Specialized Unit for Combating Terrorism (SOBT), Security Police, and Special Police Forces, which successfully completed a multi-year training mission with a U.S. Special Operations Liaison Element. The State Agency for National Security (DANS) has intelligence-gathering units responsible for CT. Since 2014, DANS also houses the National Counterterrorism Center. In June, the interior minister and the prosecutor general announced plans to design new CT centers, though they have not yet made public additional details.

In 2017, Bulgaria implemented new legislation directing that public buildings, including schools, transportation hubs, and hospitality and tourism sites and facilities - as well as houses of worship and other public facilities - develop CT risk assessments and prevention and response measures in the event of a terrorist attack. In advance of the summer tourism season on the Black Sea coast, the Ministry of the Interior regularly updates its emergency plans in coordination with its foreign counterparts.

Bulgaria continues to implement strong migration controls and maintains an engineered obstacle (fencing with razor wire) and sophisticated monitoring systems along most of the EU's "external" border with Turkey. Bulgaria makes widespread use of all available terrorist screening watchlists and shares API data from the biographic passport page of travelers arriving on passenger flights with other EU countries when it encounters watchlisted individuals. Based on bilateral police cooperation agreements, Bulgaria also shares this type of information with non-EU countries for law enforcement purposes on an as-needed basis. U.S. government agencies continued to work closely with Bulgarian counterparts through a variety of CT programs aimed at enhancing Bulgaria's capacity and capabilities. The Department of State partnered with Bulgaria to implement key screening programs in border security and aviation security.

In June, local police arrested and charged a self-radicalized 16-year-old Bulgarian student with planning a terrorist attack in the city of Plovdiv. The suspect had reportedly assembled several improvised explosive devices. As of December, the specialized court for organized crime is still hearing the case against two suspected accomplices in Hizballah's 2012 Burgas airport bombing, following procedural issues that caused multiple delays in the trial.

Bulgaria relies heavily on specialized law enforcement units like SOBT for a wide range of missions, including CT and border security operations, but it has not adequately invested in training and equipping these units. Moreover, resources are concentrated in Sofia and the units there lack the airlift capabilities needed to respond in a timely manner to incidents elsewhere in the country. Similarly, the specialized court for organized crime has not been adequately staffed and resourced to handle the increased workload resulting from its new jurisdiction over terrorism cases. Bulgarian authorities also do not have extensive and recent experience investigating and prosecuting CT cases and do not regularly employ interagency task forces that would be necessary to effectively handle complex investigations. 
Countering the Financing of Terrorism: Bulgaria is a member of MONEYVAL. Its FIU, the Financial Intelligence Directorate - State Agency for National Security, is a member of the Egmont Group. Bulgaria is also a member of the Defeat ISIS Coalition's CIFG.

In September, Bulgarian prosecutors indicted a group of five Syrians and one Bulgarian on charges of terrorist financing. The General Directorate for Combatting Organized Crime arrested the group in January for allegedly transferring more than \$10 million through the hawala system and purchasing and transporting to the Turkish-Syrian border more than 100 vehicles in support of terrorist organizations in Syria such as Hay'at Tahrir al-Sham.

Countering Violent Extremism: The government is implementing its 2015-2020 Strategy for Countering Radicalization and Terrorism. In October, the government approved a report for activities undertaken in 2018 and an action plan for 2019.

In December, the Pazardzhik District Court sentenced to prison Islamic preacher Ahmed Mussa and 13 of his followers within the Roma Muslim community for propagating religious hatred and incitement to war in support of ISIS. The group had allegedly helped smuggle across the border several FTFs en route to Syria, though it is not clear whether they were fully aware of the FTFs' terrorist affiliation, and some human rights groups have viewed the proceedings as an infringement on religious freedom. Mussa has been in prison since April, serving a four-year sentence for "spreading an antidemocratic ideology and incitement of war, religious hatred, and discrimination." Bulgarian authorities continue to have concerns that the city of Pazardzhik could once again serve as a waypoint for FTFs if ongoing conflicts in the Middle East trigger another massive influx of migrants.

In December, the Bulgarian government co-hosted with the Department of State and the International Republican Institute a regional forum focused on building resilience to terrorist radicalization and recruitment in the Western Balkans. Participants from throughout the region explored ways to strengthen regional cooperation and increase the exchange of information in the fight against terrorism.

International and Regional Cooperation: Bulgaria is a member of and active contributor to CT initiatives at the UN, the EU, NATO, the OSCE, and the Organization for Black Sea Economic Cooperation.

\section{CYPRUS}

Overview: The Republic of Cyprus collaborated closely with the United States, the EU, and other countries - bilaterally and multilaterally - in international counterterrorism efforts in 2019. In particular, Cyprus continued to make significant progress on strengthening its banking sector's CFT efforts. The Republic of Cyprus is a member of the Global Coalition to Defeat ISIS.

Since 1974, the island of Cyprus has been divided de facto into the Republic of Cyprus government-controlled area in the southern two thirds of the island, and the northern third which is administered by the Turkish Cypriots. A UN peacekeeping force patrols a buffer zone, also 
called "the Green Line," which separates the two sides. The buffer zone is largely open to civilian traffic and remains a significant route for the illicit transit of people, narcotics, and other contraband.

The division of the island has impeded CT cooperation between the two communities and between the Republic of Cyprus and Turkey, which do not maintain diplomatic relations. This report covers only the Republic of Cyprus. It does not address terrorism or CT efforts in the areas under the administration of Turkish Cypriots.

2019 Terrorist Incidents: There were no reported terrorist incidents in the Republic of Cyprus in 2019.

Legislation, Law Enforcement, and Border Security: In November 2019, the United States and the Republic of Cyprus marked the first anniversary of the joint Statement of Intent on Security Cooperation, noting progress on several fronts.

The Republic of Cyprus is working with the United States to create the Cyprus Center for Land, Open-seas, and Port Security (CYCLOPS), a \$5 million regional training center focused on border security, including preventing the spread of weapons of mass destruction and related materiel.

The Republic of Cyprus began implementing the EU PNR Directive in 2019 after passing requisite legislation in December 2018.

In November 2019, the Republic of Cyprus proposed amendments to the way it implements the so called "Green Line Regulation," which governs crossing the green line between the Republic of Cyprus and Turkish Cypriot-administered areas. According to the Republic of Cyprus, the amendments are aimed at strengthening security and monitoring of green line crossings. It is likely that the amendments must be approved by the EU; the ROC has not yet submitted the amendments to Brussels.

Republic of Cyprus law enforcement officials participated in several U.S.-sponsored training programs on border security, CT, and CFT.

The Republic of Cyprus passed but still has not fully implemented a law regulating undercover activities by police officers.

Countering the Financing of Terrorism: The Republic of Cyprus is a member of MONEYVAL. Its FIU, the Unit for Combating Money Laundering (MOKAS), is a member of the Egmont Group.

The Republic of Cyprus underwent a mutual evaluation by MONEYVAL in 2019. Before the MONEYVAL evaluation team visit, the Republic of Cyprus completed a National Money Laundering/Terrorist Financing Risk Assessment based on World Bank tools. The Republic of Cyprus endorsed a national AML/CFT Action Plan to address issues raised in the risk 
assessment. Those efforts will be reexamined to ensure complementarity with the outcomes of the MONEYVAL report.

Countering Violent Extremism: There were no significant changes in Cyprus's CVE efforts in 2019.

International and Regional Cooperation: There were no changes in 2019.

\section{DENMARK}

Overview: The Kingdom of Denmark (which includes Greenland and the Faroe Islands) devoted significant assets to CT programs, domestically and abroad. Denmark cooperates closely with the United States, the UN, and the EU on CT initiatives, including within the GCTF and the Global Coalition to Defeat ISIS.

According to the Ministry of Justice, at least 158 people from Denmark have traveled to Iraq or Syria to join ISIS since 2012. The Danish Security and Intelligence Service (PET) remained concerned that Danish fighters returning to Denmark with terrorist training would seek to radicalize others. According to the PET-administered Center for Terror Analysis (CTA), the primary terrorist threat to Denmark is small, simple attacks perpetrated by radicalized members of the Islamic community. Radicalization in prison facilities remains a particular concern. CTA also assesses a limited but increasing threat from other terrorist actors who target Denmark's asylum centers, religious minorities, and migrants.

2019 Terrorist Incidents: There were no terrorist incidents reported in 2019.

Legislation, Law Enforcement, and Border Security: Denmark's Parliament passed an emergency bill on October 24 that provides the immigration and integration minister the authority to strip dual-national FTFs of their Danish citizenship. Lawmakers fast-tracked the bill because of concerns that detained ISIS fighters could escape SDF detention as Turkish forces entered northeast Syria. The legislation, which allows citizenship revocation without a trial, states that anyone acting in a manner seriously prejudicial to Denmark's vital interests may have their Danish citizenship revoked, unless the person would become stateless.

On January 1, Denmark adopted a PNR law that allows the government to gather airplane passengers' personal data. Danish authorities collect PNR data from air carriers and make this information available to Danish security and intelligence services.

Denmark continued to use its 2006 terrorism legislation that allows information sharing between its agencies responsible for CT and FTFs - the PET and the Danish Defense Intelligence Service (DDIS). Efforts to counter terrorism are also shared among the Danish National Police, the Public Prosecution Service, and the Danish Prison and Probation Service. Danish security and law enforcement agencies share information through the CTA, which - as the Danish government's intelligence fusion center - constitutes the focal point for reporting from the Danish National Police, PET, DDIS, the Ministry of Foreign Affairs, and the Danish Emergency 
Management Agency. The Danish police and the Danish defense forces share responsibility for preventing terrorist attacks in Copenhagen and on the borders.

Counterterrorism-related prosecutions and actions by law enforcement included:

- On May 20, a Syrian asylum seeker received a 12-year prison sentence for planning to detonate explosive devices in Copenhagen in 2016. Moyed Al Zoebi was found guilty in April and was determined to have acted on behalf of ISIS.

- On November 28, three men were convicted of promoting ISIS by supplying drone equipment to ISIS fighters from 2013 to 2017. Two of the defendants were acquitted of more serious terrorism charges. The sentences ranged from two and a half to four years' confinement.

- On December 11, Danish police arrested 21 individuals suspected of terrorist activities. Police raided and searched 20 locations spanning seven police districts in connection with the terrorism investigation. Eight suspects were charged in Copenhagen with serious terrorism offenses that carry potential life sentences if convicted. Police spokespersons said that the accused individuals attempted to obtain firearms and possessed materials used to build explosive devices. A PET official said they believed that a "militant, Islamist motive" motivated the suspects.

Countering the Financing of Terrorism: Denmark is a member of the FATF. Its FIU, The Money Laundering Secretariat (FIU Denmark), is a member of the Egmont Group. Denmark is also a member of the Defeat ISIS Coalition's CIFG. In September, Denmark pledged \$2 million in support of Ethiopia's efforts to counter terrorist financing as part of a larger commitment to support global CT efforts.

Countering Violent Extremism: In September, Denmark committed nearly \$1.5 million for a CVE center under the regional organization for the countries of the Horn of Africa: the Intergovernmental Authority on Development (IGAD). Denmark's foreign minister also pledged $\$ 2$ million to the GCERF, a global fund dedicated to countering radicalization and recruitment. In April, the U.S. embassy sponsored American Imam Talib Sharif to speak in Copenhagen to various religious and interfaith groups about anti-radicalization and community activism. Denmark's National Center for the Prevention of Extremism announced in October that it would fund a postdoctoral program focused on "extreme Islamism" in the country. The National Center also partnered with University College Syd to develop learning materials aimed at giving children tools to maintain a critical approach to information they encounter online and on social media.

International and Regional Cooperation: The Danish government is committed to working within the UN framework, through the EU, and with other international and regional organizations. Denmark actively participates in the GCTF, the CoE, NATO, the OSCE, INTERPOL, the Bern Club, and the European Counterterrorism Center. In October, Denmark announced new military deployments to the Sahel region supporting both the UN peacekeeping mission in Mali, MINUSMA, and the French-led CT mission in the Sahel, Operation Barkhane. 


\section{FRANCE}

Overview: France remained a key partner of the United States in international CT efforts in 2019. It is a longstanding and important member of the Global Coalition to Defeat ISIS. France continued to conduct important CT operations in Iraq, Libya, Mali, Syria and the Sahel region, as well as in the Lake Chad Basin.

The terrorist threat in France remained high but was lower than its 2015 peak. French law enforcement remained concerned with the threat of domestic terrorism inspired by or affiliated with ISIS. French law enforcement and intelligence agencies thwarted at least four attacks in 2019 and arrested at least 12 individuals on Islamist terrorism-related charges. French authorities also arrested two individuals linked to REMT. The new national CT prosecutor's office became operational in July and is responsible for the investigation and prosecution of all terrorism-related cases.

2019 Terrorist Incidents: Four suspected terrorist attacks took place in 2019, with limited casualties. Below are the details on each of the attacks.

- On March 5, a prison inmate and his girlfriend in Condé-sur-Sarthe carried out a knife attack against two prison guards while in the family visiting unit. The girlfriend smuggled a ceramic knife inside the prison. She girlfriend died during the police response, while the assailant and two prison guards were injured. The attacker had pledged allegiance to ISIS.

- On May 24, a package filled with screws and nails exploded in Lyon's city center, injuring 13 people. With the help of Lyon's system of surveillance cameras, the suspect was identified and arrested three days later. The attacker was reportedly a 24-year-old male Algerian national who had pledged allegiance to ISIS.

- On October 3, a 45-year-old male employee carried out an insider knife attack inside Paris Police Headquarters, killing four colleagues and injuring one before he was shot dead. While the assailant had ties to radicalized Salafists and ISIS propaganda was found in his possession, he also harbored grievances related to his treatment as a person with deafness and muteness.

- On October 28, an 84-year-old male with ties to the National Gathering party attempted to set fire to a mosque in the southern city of Bayonne. The attacker shot two worshippers who caught him in the act. The attacker claimed he was avenging the fire of the Notre Dame Cathedral, which he blamed on Muslims. The government charged the attacker with attempted homicide but did not categorize the attack as terrorism.

Legislation, Law Enforcement, and Border Security: On July 15, the government released its new French National Intelligence Strategy (2019-2024), and countering terrorism is the government's top priority. The strategy breaks down the ongoing domestic terrorism threat into 
three categories: "projected" threats (from overseas to France), threats "inspired" by terrorist organizations, and groups that may be susceptible to "Islamist radicalization."

The French armed forces continued Operation Sentinelle, a domestic deployment of up to 7,000 soldiers to enhance security at sensitive sites and large events throughout the country. France maintained extraordinary border controls, in place since November 2015, with its Schengen neighbors.

France has a fully operational inter-ministerial Passenger Information Unit (PIU) that uses API/PNR data to screen arriving and departing passenger data against other police and administrative databases. In accordance with French privacy laws, the data is accessible only by PIU staff. To query API/PNR data, police/intelligence services must submit requests, which are approved on a case-by-case basis. French agencies each have their own fingerprint and/or biometric systems, which are not always compatible with one another and do not cross-pollinate, potentially impeding efforts to identify FTFs returning to France or Europe.

On March 23, the new national counterterrorism prosecutor's office (PNAT) was created as part of judicial reforms. The PNAT became operational in July and is responsible for the judicial investigation and prosecution of all terrorism-related cases. With a team of 27 prosecutors, the PNAT worked with the United States to incorporate U.S.-collected battlefield intelligence to prosecute terrorists.

French law enforcement is highly effective in handling terrorism cases. According to French government sources, France thwarted at least four attacks in 2019, including one 9/11-inspired terror attack. Most terrorism-related arrests were made by domestic intelligence and involved individuals and groups suspected of having links to ISIS, but authorities also targeted Shiite and REMT groups. To improve internal information sharing to combat terrorism, on February 18 the government created an interagency coordination office including 13 intelligence and law enforcement agencies.

Some high-profile terrorist cases in the judicial system include:

- On October 14, the Special Criminal Court sentenced the two main defendants of a female jihadist cell to 25 and 30 years in prison over a failed attempt to detonate a car bomb outside Notre Dame Cathedral in September 2016.

- On October 21, the PNAT completed its investigation of the November 2015 terrorist attacks in Paris. The PNAT also received U.S.-provided assistance, including intelligence collected from the battlefield. The trial is expected to begin in 2021.

- Also on October 21, the PNAT completed its investigation of the August 2015 Thalys train attack, in which three U.S. citizens stopped the attacker. A date for the trial has not been announced. 
Countering the Financing of Terrorism: France is a member of the FATF. Its FIU, the Intelligence Processing and Action against Illicit Financial Networks Unit (Tracfin), is a member of the Egmont Group. France is also a member of the Defeat ISIS CIFG.

In November, France published new guidelines on the risk approach, due diligence requirements for clients and their beneficiaries, the notion of politically exposed persons, and the obligation to report to Tracfin. France included countering the financing of terrorism as one of the three priorities to counter terrorism during its G-7 presidency.

France continued to investigate and prosecute financing of terrorism cases in 2019. French financial and non-financial institutions reported 95,731* suspicious transactions to Tracfin in 2019, with some four percent investigated for links to terrorism financing according to the French government. On November 7, the Paris appeals court determined that French-Swiss firm Lafarge had violated international embargoes as it sought to maintain operations at its cement plant in Jalabiya, Syria. The company was indicted in 2018 for making payments to ISIS to protect the plant.

Countering Violent Extremism: In 2019, the government continued to implement its 2018 National Plan to Prevent Radicalization. Presenting its one-year assessment of the plan's implementation at an April 11 press conference, the government identified four areas where additional focus is required to counter terrorist radicalization and recruitment: prison, delinquency prevention programs, poverty prevention programs, and government programs to promote social cohesion.

In May, France hosted and co-chaired with New Zealand the Christchurch Call to Action Summit in Paris. Bringing together several countries and technology companies, the Christchurch Call aims to eliminate terrorist content online. On September 19 on the margins of the UN General Assembly, France also released a "Charter for a Free, Open, and Safe Internet" for governments and companies to endorse. On September 23, France then co-sponsored with New Zealand and Jordan at the United Nations the high-level "Leaders Dialogue: Strategic Responses to Terrorist and Violent Extremist Narratives."

Following the October 3 insider attack at the Paris Police headquarters, the Office of Intelligence Services Inspection conducted an assessment of "radicalization among government officials." As of October 21, approximately 67 police officers were flagged for possible radicalization. Of those, approximately 20 were dismissed, three were suspended, and two had to turn in their weapons. Bordeaux, Montreuil, Paris, and Sarcelles are members of the SCN. Alumni of Department of State-sponsored City Pair exchanges participated in a CVE symposium in Paris in April with counterparts from Belgium, Germany, the UK, and the United States.

International and Regional Cooperation: France is a founding member of the GCTF and actively participates in the OSCE. France plays a vital role on the UN Security Council ISIL and al-Qa'ida Sanctions Committee. The French government undertook joint CT operations with several EU partners and played an active role in CT capacity building in other countries, particularly in West Africa. 
*Updated on July 29, 2020

\section{GEORGIA}

Overview: In 2019, Georgia, a longstanding member of the Global Coalition to Defeat ISIS, continued its robust engagement with the United States across a range of CT-related issues. Georgia participated in numerous bilateral CT exercises and trainings with the United States and remained a strong U.S. security partner. The State Security Service of Georgia (SSSG) is Georgia's lead agency for terrorism-related incidents and investigations. In addition to implementing several amendments to the criminal code aimed at strengthening CT legislation, Georgia adopted its three-year National Strategy for the Fight Against Terrorism and action plan following the establishment of its SSSG-led Permanent Interagency Commission in 2018.

2019 Terrorist Incidents: There were no terrorist incidents in Georgia in 2019.

Legislation, Law Enforcement, and Border Security: Georgia is generally capable of detecting, deterring, and responding to terrorism incidents. The SSSG is the lead agency handling terrorism-related incidents and investigations, and is generally well equipped and well trained. The SSSG's Counterterrorism Unit continues to receive regular training and equipment. In January, recognizing the need for a whole-of-government response to the challenges of terrorism, the Georgian government approved the National Strategy of Georgia on the Fight Against Terrorism 2019-2021 with an accompanying action plan. The SSSG-chaired Permanent Interagency Commission is responsible for oversight of the strategy and action plan and providing annual status reports on implementation. In 2019, Georgia also carried out exercises to enhance interoperability and cooperation between agencies with CT-related mandates.

Georgia continued in 2019 to improve its border, maritime, and aviation security. The EU is supporting Georgia with implementation of its API/PNR data systems in line with UNSCR 2396. In November, Georgian authorities cooperated closely with the Security Service of Ukraine (SBU) and other international partners in the SBU's detention of ISIS commander and Georgian citizen Tsezar Tokhosashvili, aka Al Bara Shishani, in Ukraine. Tokhosashvili, who was deputy to former ISIS commander and Georgian citizen Tarkhan Batirashvili, aka Abu Omar al Shishani, entered Ukraine on falsified documents in 2018 and had been coordinating ISIS activities from Ukraine over the past year.

Countering the Financing of Terrorism: Georgia is a member of MONEYVAL. Georgia's FIU, the Financial Monitoring Service of Georgia (FMS), is a member of the Egmont Group. Georgia is also a member of the Defeat ISIS Coalition's CIFG.

On October 30, Georgia adopted the Law on Facilitating the Prevention of Money Laundering and Terrorism Financing, which the FMS drafted. The new legislation aims to create effective monitoring and enforcement mechanisms, enhances the ability of law enforcement to retrieve information from the FMS, and includes insurance brokers, law firms, and certified accountants in the list of reporting entities. 
Countering Violent Extremism: In 2019, Georgia continued its CVE efforts by focusing on initiatives in education, civic and political participation, media and access to information, gender equality, preserving minority culture and identity, justice and law-enforcement activities, and social and regional integration.

In June, Georgia and the OSCE jointly hosted a seminar on the involvement of society in the prevention of terrorism. The seminar, the first of its kind to be hosted in Tbilisi, emphasized prevention-oriented measures as a key component of Georgia's National Strategy on the Fight Against Terrorism. In 2019, Georgia continued to work with international and local partners on multi-year CVE projects including the "Pankisi Eco-Links" project with USAID, which aims to bridge inter-community divides and economic and social isolation in the Pankisi Gorge region by facilitating people-to-people interactions around economic incentives.

International and Regional Cooperation: Georgia is actively engaged on CT issues at the international, regional, and bilateral levels. Georgia cooperates closely with NATO; the CoE; the OSCE; the Organization of Black Sea Economic Cooperation; and the Georgia, Ukraine, Azerbaijan, and Moldova (GUAM) Organization for Democracy and Economic Development.

In November, Georgia and the EU jointly hosted a seminar for media and civil society representatives in Georgia on the role of media in countering terrorism and organized crime. The seminar aimed to deepen cooperation between media and law enforcement on CT issues, and experts from the United Kingdom presented best practices.

In 2019, Georgia participated in the third and fourth plenary meetings of the CoE's CT committee. The SSSG also represented Georgia in the 22nd and 23rd sessions of GUAM's Counterterrorism sub-working group.

\section{GERMANY}

Overview: Germany continued its CT cooperation with the United States and the international community as a member of the Global Coalition to Defeat ISIS and the GCTF and in multilateral CT operations in Africa and the Middle East. In 2019, Germany allocated more resources toward combating all forms of terrorism. Law enforcement targeted a range of suspects, including Islamist terrorists and REMT actors. German officials describe the latter as an increasing trend and the greatest threat to national security. A new 10-point plan outlined in October 2019 commits, among other things, to create more than 700 new jobs in federal law enforcement and intelligence agencies focused on combating REMT (which Germany refers to as "right-wing extremism), including a dedicated unit to monitor related online activities. The 2018 report by Germany's domestic security agency, which contains the most recent statistics available, reported there were 24,100 REMT actors, 100 more than in 2017, of whom 12,700 were considered "violence-oriented." The number of violent crimes committed by these extremists rose by 3.2 percent, from 1,054 in 2017 to 1,088 in 2018.

\section{Terrorist Incidents:}


- In June 2019, a Neo-Nazi extremist shot and killed politician Walter Lübcke (of the Christian Democratic Union).

- On October 9, a man armed with multiple firearms and home-made bombs attempted to force his way into a synagogue in Halle during Yom Kippur prayers, instead killing two other victims at random. The perpetrator posted video and text material online expressing extremist anti-Semitic, anti-immigrant, and misogynistic ideology and admiration for earlier perpetrators of racially or ethnically motivated terrorism.

- On November 19, police arrested a Syrian national in Berlin on suspicion of planning a terrorist attack and communicating with Islamist extremists on ways to manufacture weapons and explosives.

Legislation, Law Enforcement, and Border Security: Germany bolstered its CT tools in 2019 through amendments to the Nationality Act that entered into force on August 8. Germans with dual citizenship who participate in combat activities for a foreign terrorist group abroad can now lose their German citizenship. The amendment applies only to adults who have a second nationality. It will not be applied retroactively, and thus will not apply to German citizen fighters currently held in SDF custody in Syria.

In a ruling related to a legal petition by German citizen family members of a FTF to be repatriated from the conflict zone, the Berlin/Brandenburg Higher Administrative Court ruled November 6 that the importance of preserving the constitutionally protected family unit must be weighed against the potential security threat posed by the returnee. The court stated it must individually review each case of returning citizen FTFs, their spouses, and their children.

Both federal and state-level law enforcement agencies conduct CT investigations. They are coordinated through the Joint Counter-Terrorism Center, consisting of 40 internal law enforcement and security agencies. In 2019, the Federal Prosecutor's Office opened 590 new terrorism investigations. Law enforcement agencies significantly increased the number of Gefährder (dangerous persons) deported in 2019, but federal statistics are not yet available. Germany continued to participate in international efforts to enhance border security. It adopted legislation to collect and analyze PNR data under EU law, though there is currently a legal challenge to the storage of this data.

Significant law enforcement actions in 2019 included:

- In November, the court began a trial against a German soldier who posed as a Syrian refugee to orchestrate a terror attack against politicians in hopes of framing Islamist extremists.

- The government dedicated increased resources to combating REMT, including risk assessment systems and online monitoring tools. The Federal Criminal Police Office will hire hundreds of new staff to work on this threat.

Germany continued to examine the circumstances that led to the December 19, 2016, Christmas Market terror attack. The Bundestag and two state parliaments (North-Rhine Westphalia and Berlin) continued to conduct hearings to evaluate law enforcement's performance in the case, 
including law enforcement coordination among different agencies and states, and police practices.

Countering the Financing of Terrorism: Germany is a member of the FATF. Its FIU, the Financial Intelligence Unit Germany, is a member of the Egmont Group. The FIU is working to eliminate a backlog of cases and will undergo a FATF Mutual Evaluation Report in 2020. Germany is also a member of the Defeat ISIS Coalition's CIFG.

The North Rhine-Westphalia (NRW) Task Force against Terror Financing, Organized Crime, and Money Laundering and the Düsseldorf public prosecutor executed 62 search warrants across NRW and coordinated raids in Baden-Württemberg, Berlin, Hamburg, Hesse, and the Netherlands on November 18.

The Federal Criminal Police and Europol assisted Spanish law enforcement with uncovering a 71-year-old Iraqi-born Spanish citizen who was funding the return of ISIS fighters to Europe through a hawala system of remittances. Spanish authorities arrested the perpetrator in November 2019, though investigations are ongoing.

Countering Violent Extremism: In 2019, Germany maintained funding for existing countering terrorist radicalization and recruitment programs and earmarked a total of \$255 million for programs that target all types of terrorism, including a \$118 million National Prevention Strategy Against Islamist Extremism and special programs concerning returning FTFs and their families. The majority of programs are federally funded, led jointly by the Federal Interior and Family Ministries, and implemented locally through the states and NGOs. The program focuses on local communities, schools, and refugee integration centers giving special attention to prevention and de-radicalization through the internet, refugee integration, and prisons. These programs have mandatory evaluation requirements and local research institutions have begun to engage in research related to countering radicalization and recruitment. The federal government announced it will continue its funding for preventing "extremism" in the 2020 budget plan.

The federal "Live Democracy!" program is a cornerstone of the government's strategy to counter terrorist radicalization, prevent enmity against people, and promote democracy. The government allocated approximately $\$ 127$ million for related projects in Germany. The German cities of Augsburg, Berlin, Dresden, and Düsseldorf are members of the SCN. In 2019, the cities of Bonn, Cologne, and Dusseldorf participated in a City Pair exchange with U.S. cities Anaheim and San Diego.

International and Regional Cooperation: In 2019, Germany assumed co-leadership of the GCTF West Africa Working Group. The United States and Germany were co-leaders of the GCTF "Initiative to Counter Unmanned Aerial System Threats," which led to the Berlin Memorandum on Good Practices for Countering Terrorist Use of Unmanned Aerial Systems, endorsed at the Tenth GCTF Ministerial Plenary Meeting in New York in September 2019. Germany remains an active participant in other GCTF initiatives. In May 2019, Germany organized a workshop, Strengthening Capacities to Prevent and Counter Terrorism by Enhancing Cross-Border Collaboration and Information Exchange on Foreign Terrorist Fighters Between 
Law Enforcement Agencies, under the auspices of the GCTF FTF Working Group. Germany also cooperates with other OSCE-participating states in the fight against terrorism. 


\section{GREECE}

Overview: The Greek government remained a collaborative CT partner in 2019. The Greek Parliament passed legislation to criminalize terrorist travel and the provision of material support to terrorists. Following Greece's first comprehensive national assessment of money laundering and terrorist financing in 2018, the FATF upgraded Greece's standing in 2019. Greece continued to vet irregular migrants arriving in significant numbers. Greece worked toward implementing its PNR law to screen air passengers in accordance with international standards. There were no major terrorist incidents in Greece in 2019; however, domestic groups carried out intermittent small-scale attacks. Greece is a member of the Global Coalition to Defeat ISIS.

2019 Terrorist Incidents: There were intermittent domestic terrorist incidents in 2019:

- On March 22, two unidentified perpetrators on a motorcycle threw a grenade that exploded in front of a police guard booth outside the consular section of the Russian Embassy resulting in minor damage. A group called FAI/IRF Revenge Cell Mikhail Zhlobitski later claimed responsibility for the attack on an anti-establishment website.

- On November 1, approximately 10 perpetrators broke into the offices of far-right political party Golden Dawn and set off an improvised explosive device that caused a fire and material damages. No organization has claimed responsibility for this attack.

- Greece experienced small-scale disturbances conducted primarily by domestic anarchists often acting in solidarity with incarcerated terrorists. Examples of these incidents included vandalizing government buildings, private residences of Greek politicians, and foreign missions with paint and leaflets.

Legislation, Law Enforcement, and Border Security: On November 13, the Greek Parliament passed changes to the penal code to increase penalties for some terrorist acts and to adopt elements of EU Directive 2017/541 criminalizing terrorist travel, training, and the provision of material support. Greece's law enforcement and border security officials used watchlists, databases, and biometrics to detect, deter, and prevent acts of terrorism. Greece is working toward implementing its 2018 PNR law to prevent, detect, investigate, and prosecute terrorist offenses and serious crime.

Greek authorities arrested domestic and international terrorists, including:

- In May, Greek officials arrested an Iraqi national pursuant to a European arrest warrant issued by German authorities, charging the individual with terrorism, genocide, crimes against humanity, and war crimes against humanity. Greece extradited the individual to Germany in September.

- In November, Hellenic Police launched a large-scale operation, uncovering a cache of weapons, including explosives, and arresting three suspects affiliated with the "Revolutionary Self Defense" domestic terrorist group that was responsible for five attacks since 2014.

- In December, Hellenic Police found and defused an improvised explosive device placed close to a central Athens police station and a university campus. Authorities noted the 
lack of warning message that domestic groups typically send and assessed that the device, described as a nail bomb, was intended to kill and maim. No one claimed responsibility for the device.

Despite objections from the U.S. government and others, convicted terrorist Dimitris Koufontinas was granted furlough from prison at the start of January; his subsequent requests for furlough have been denied. Koufontinas is serving 11 life sentences plus 25 years for murder and his leadership role in "November 17", the name of the terrorist group that targeted and assassinated members of the U.S. Mission to Greece, as well as British and Turkish diplomats, Greek politicians, and Greek citizens.

The porous nature of Greece's borders remained a concern as irregular migrants continued to arrive in Greece in significant numbers. Beginning in the summer of 2019, Greece experienced a sharp increase in such arrivals, with more than 10,000 between September 30 and November 3. Greece's national identification card remained extremely vulnerable to alteration and photo substitution; it has not incorporated security features, such as digitized photo and biometrics. The Greek government committed to address this vulnerability through the introduction of a biometric national identification card in the near future.

Countering the Financing of Terrorism: Greece is a member of FATF. Its FIU, the AntiMoney Laundering Counter-Terrorist Financing and Source of Funds Investigation Authority, is a member of the Egmont Group.

In September, FATF completed its mutual evaluation of Greece. The report concluded Greece has the foundations for effective action against money laundering and terrorist financing but needs to improve prosecution of these crimes and focus on risks in the nonfinancial sector. The FIU inspected more than 2,000 suspicious transactions in 2019 but did not report evidence of terrorist financing in Greece.

Countering Violent Extremism: There were no significant changes in Greece's CVE efforts since the 2018 report.

International and Regional Cooperation: Greece is a member of various international bodies and of the Global Coalition to Defeat ISIS.

\section{ITALY}

Overview: Italy collaborated closely with the United States, the EU, and the UN in its international CT efforts. Domestically, Italy investigated and prosecuted terrorist suspects within its borders and deported 98 subjects for terrorism-related security reasons in 2019. Italy is a member of the Global Coalition to Defeat ISIS. As part of the Coalition, Italy was among the top contributors of troops in Iraq, heads the Coalition's police training sub-group, and leads efforts to train Iraqi police and security forces. Italy continued to co-chair the Coalition's CIFG with the United States and Saudi Arabia. Italy is a Framework nation and the fourth-largest troop contributor to NATO's Resolute Support Mission in Afghanistan. 
In June, Italian and U.S. authorities cooperated to repatriate one Italian FTF from Syria to face prosecution for terrorism-related crimes in Italy. Italian authorities are concerned about the risk posed by returning fighters, as well as fighters dislodged from areas formerly under ISIS control in Libya and elsewhere who may try to use migrant flows to reach Italy. In addition, officials are concerned fighters from the Western Balkans returning to Europe could also pass through Italian territory, given the significant Balkan-origin communities in Italy.

2019 Terrorist Incidents: Yemeni national Mahamad Fathe was arrested in Milan September 17 for stabbing a soldier. Fathe had met with "radicalized" suspects in Germany and fought in the civil war in Yemen. The detainee's lawyer requested a psychiatric review, as Fathe told investigators he was suicidal.

Legislation, Law Enforcement, and Border Security: Under the auspices of the U.S.-Italy Counterterrorism Working Group (a component of the U.S.-Italy Strategic Dialogue), Italian authorities are working to share best practices on migrant screening. The Italian government continued to make use of 2005 legislation facilitating the detention of terrorist suspects and expedited procedures for expelling non-citizens suspected of endangering national security. Italy deported 98 individuals on security grounds in 2019, compared with 126 in 2018. Prominent arrests and expulsions included:

- On February 28, Italian authorities arrested Algerian citizen Mourad Sadaoui in Caserta pursuant to an INTERPOL Red Notice requested by Algerian authorities seeking to prosecute him on terrorism charges for having traveled from Algeria to Syria to join ISIS in 2014. Sadaoui lived in Italy on a work permit from 2003 to 2013. Italian police told the media Sadaoui was the first ISIS FTF returnee arrested in Italy.

- On April 13, the Italian Ministry of Interior (MoI) announced the expulsion of Naser Baftija, a 39-year-old Kosovar resident in Cremona, on grounds that he was considered a "threat to the security of the country" because he "sought to radicalize" students attending his classes, as well as the local Muslim population in Mantua and Cremona.

- On April 17, Italian authorities arrested Islamic convert Giuseppe Frittitta and Moroccan national Ossama Ghafir in Milan and Novara, respectively. Both Frittitta and Ghafir were charged with terrorism-related offenses, including support for committing crimes of terrorism and self-training in activities for the purpose of terrorism.

- In September 2019, Italian police arrested eight Tunisians and two Italians in Abruzzo suspected of financing activities linked to Al-Nusra in Syria. They allegedly used money obtained through tax evasion to finance militant groups in Syria and radical imams in Italy.

- On November 12, police arrested bank clerk Andrea Chesi and his son Yuri, who were accused of having established a REMT terrorist cell in Sovicille, in the province of Siena, and planning to attack the mosque in Colle Val d'Elsa (Tuscany). Investigators searched their residences, seizing explosives, pistols, and rifles.

- On November 28, police detained 19 suspects in Sicily and Northern Italy linked to a REMT group that allegedly sought to build a new Nazi party in Italy. According to media reports, some of the suspects had weapons, access to explosives, and conducted recruitment activities on social media. According to police statements to the media, the group was forging links with other REMT groups in the UK and Portugal, and it was in 
the early stages of planning attacks on the Milan and Rome headquarters of the National Italian Partisans Association, the veterans group of anti-Mussolini resistance fighters in World War II.

- On December 2, the MoI announced the expulsion of two noncitizens considered a threat to the security of the country, as they had been "seeking to radicalize" the local Muslim population. According to the MoI, Jounayed Ahmed, a 19-year-old Bangladeshi imam, who is a legal resident in Padua, "sought to radicalize" students attending his religious courses. A second individual, Mohamed Bendafi, a 24-year-old Moroccan resident in Turin, also was expelled after authorities determined he had posted explicit videos and messages on social media inviting other Muslims to travel to Syria to join jihadist groups.

Countering the Financing of Terrorism: Italy is a member of the FATF, and its FIU is a member of the Egmont Group. Italy remained a co-lead of the Defeat ISIS Coalition's CounterISIS Finance Group, along with the United States and Saudi Arabia, and leads the police training sub-group. In March 2019, the Head of the UN Office of Counter-Terrorism (UNOCT) signed an MOU with the Italian Guardia di Finanza $(\mathrm{GdF})$, for the $\mathrm{GdF}$ to provide capacity-building cooperation and training to other member states on countering the financing of terrorism.

Countering Violent Extremism: No changes since last year.

International and Regional Cooperation: Italy continued to support CT efforts in regional and multilateral organizations, including NATO, the OSCE, and the GCTF.

Italy strengthened its CT capacity building efforts in Libya, focusing on coast guard cooperation, investigative training for law enforcement, and border security measures. The Italian military continued its training activities in Niger with local security forces in support of the efforts of Nigerien authorities and G5 Sahel member states to strengthen border security, counter illicit trafficking, and combat threats to regional security.

\section{KOSOVO}

Overview: Kosovo continued to fight the threat of terrorism through close cooperation with the United States. Kosovo is a member of the Global Coalition to Defeat ISIS. The Government of Kosovo (GOK) is approaching the end of the timeframe envisaged by its comprehensive CVE strategy and is preparing a new comprehensive strategy and action plan for the incoming government to consider for 2020-2025.

On April 20, with U.S. assistance, Kosovo repatriated four suspected FTFs and 106 family members from Syria, becoming one of the first countries to return a large number of civilians from the conflict zone. Three of the four alleged FTFs were held in pretrial detention, while the fourth, an 18-year-old, was released and will be investigated as a juvenile. The women and children, following an initial holding period of 72 hours to provide physical and mental health screenings, were returned to their families and communities. The GOK professionally handled the returns during the initial 72-hour period. Although the government is operating a Prevention and Reintegration Division within its Ministry of Internal Affairs, limited resources and capacity 
continue to impede the government's ability to provide returnees with adequate services and assistance.

2019 Terrorist Incidents: There were no reported terrorist incidents in Kosovo in 2019.

Legislation, Law Enforcement, and Border Security: Kosovo's legislative framework is sufficient to prosecute individuals suspected of committing or supporting terrorist activities, but implementation is lacking, particularly with short sentences, early release from prison, and a lack of post-release supervision. Kosovo supports the implementation of UNSCR 2396 to counter terrorist travel and is working to implement it in practice.

On September 4, the Pristina Basic Court convicted six defendants for planning terrorist attacks in Kosovo, Albania, Belgium, France, and North Macedonia, including planned suicide bombings in Kosovo against KFOR troops, night clubs, and Serb Orthodox churches between December 2017 and June 2018. The lead defendant was sentenced to 10 years' imprisonment. The remaining defendants received lesser, but still significant, sentences. This case followed months of Kosovo Police and Kosovo Intelligence Agency operations with substantial U.S. investigative and prosecutorial assistance, including the tracking of attempted arms purchases.

On November 7, the Special Prosecutor's Office of Kosovo (SPRK) filed charges in the Pristina Basic Court, Special Department, against the first of the four suspected FTFs who had been repatriated from Syria in April. Prosecutors and investigators are using battlefield evidence provided by the U.S. interagency on the suspected FTFs and some women. This first FTF pleaded guilty to participation in a terrorist group and was sentenced to four years in prison, including time served in pretrial detention. Thanks to his guilty plea, the sentence represented a permissible departure below the minimum sentence under Kosovo law (five years). A second FTF suspect was indicted on December 10.

The Pristina Basic Court in 2019 accepted guilty pleas for participation in a terrorist group from two of the women returnees from Syria, sentencing them each to suspended sentences. Under the terms of their sentences, the women will avoid time in prison if they do not commit further crimes, regularly check in with $\mathrm{KP}$, and attend mandatory psychotherapy sessions. In November, similar indictments were filed against four additional women returnees, and three further women were indicted in December.

On November 18, the SPRK indicted a Kosovo citizen for incitement to commit a terrorist offense after the individual published open support and praise for the terrorist attacks in Sri Lanka via social media.

On June 27, President Thaci issued a decree obligating Kosovo security institutions to create a domestic list of persons, groups, and organizations involved in terrorism who would be subject to restrictive measures in the country. President Thaci stated that until such a list is created domestically, Kosovo security institutions will implement the EU's list, which includes Hizballah. 
Countering the Financing of Terrorism: Kosovo's FIU is a member of the Egmont Group. There were no significant updates in 2019.

Countering Violent Extremism: Kosovo's CVE strategy and action plan (2015-2020) provides a five-year roadmap for stemming the growing threat of terrorism through a whole-ofgovernment approach, emphasizing the critical role of local stakeholders and civil society. Implementation has been uneven across government ministries, and challenges continue, owing to a lack of capacity and inadequate resources. An inter-ministerial working group is drafting a revised strategy on counter terrorist radicalization and recruitment to focus on the reintegration of returnees.

The Kosovo Justice Ministry continued its implementation of a corrections program - assisted by U.S. experts - aimed at enhancing the management of terrorists in prison; collecting, analyzing, and sharing prison intelligence within law enforcement; and managing the rehabilitation and eventual reintegration of convicted terrorists. The Ministry of Internal Affairs Prevention and Reintegration Division is tasked with reintegrating individuals who served time in prison on terrorism charges, FTF returnees, and family members - including through funding mental health treatment and facilitating access to social services - but it suffers from insufficient staffing and resources.

Kosovo organizations continued cooperative activities through the Country Support Mechanism under GCERF, a public-private global fund to support local, grassroots counter radicalization and recruitment efforts in at-risk communities.

Ferizaj/Urosevac, Gjakove/Djakovica, Gjilan/Gnjilane, Gracanica/e, Hani i Elezit/Elez Han, Kacanik, Mitrovica South, Peje/Pec, Prishtine/Pristina, Prizen, Viti/Vitina, Vushtrri/Vucitrn, and Zvecan are members of the SCN.

International and Regional Cooperation: The Government of Kosovo worked closely with officials in Albania and North Macedonia to support CT capacity building and regional cooperation.

\section{THE NETHERLANDS}

Overview: The Netherlands continues to respond effectively to the global terrorist threat in border and transportation security, counterterrorist financing, CVE, and bilateral and multilateral CT cooperation. On December 9, the Dutch lowered their national threat level from "substantial" (Level 4 of 5), where it had been since 2013, to "significant" (Level 3). The main threat is Islamist terrorism, followed by REMT (which the Dutch refer to as violent "right-wing extremism" or "right-wing terrorism"). The Dutch assess the threat of REMT violence as less acute in the Netherlands than in other European countries. The Netherlands has a comprehensive national CT strategy that implements policies to counter all forms of terrorism at the local level through multidisciplinary interagency cooperation. 
The Netherlands is a member of the Global Coalition to Defeat ISIS, participates in Coalition working groups, and is co-chair of the Coalition's FTF Working Group with Turkey and Kuwait. The Netherlands has liaisons embedded at various operational command centers, provided force protection, and contributed military personnel and trainers in Iraq. The Dutch do not contribute troops or aid in Syria. The Netherlands is a member of the GCTF.

2019 Terrorist Incidents: On March 18, a man shot random passengers on a tram in Utrecht, killing four and seriously wounding two. In a hand-written note left at the scene of the attack and in later police interviews, he cited religious reasons for his actions, including perceived mockery of Islam. Immediately following the attack, the government briefly raised the threat level to "critical," the highest level, though only locally to divert resources to the manhunt. The prosecutor charged the man, Gokmen Tanis, with multiple counts of murder with terrorist intent. The trial was scheduled to start in March 2020.

Legislation, Law Enforcement, and Border Security: The Netherlands implemented CT legislation in line with relevant UNSCRs. There were no significant changes in law enforcement structures, capacity, international cooperation, or border security legislation in 2019. On September 10, the Second Chamber of Parliament (Lower House) approved draft legislation that would make it a punishable offense to reside in an area controlled by a terrorist organization without prior permission from the government. The proposal is pending deliberations in the First Chamber of Parliament.

On June 17, the Dutch began to implement the EU directive on PNR, which requires airlines to transfer passenger information to the Dutch Passenger Information Unit to be checked against databases and risk profiles.

Significant law enforcement and judicial actions related to CT included:

- On July 23, the district court in The Hague convicted Oussama Achraf Akhlafa, a returned Dutch FTF, for committing a war crime in Syria. The suspect had his picture taken while posing next to a crucified corpse, thereby degrading the personal dignity of the victim. The court sentenced the suspect to seven-and-a-half years in prison.

- On October 14, the district court of Amsterdam convicted 20-year-old Jawed Sultani for stabbing two U.S. tourists in Amsterdam central station on August 31, 2018. The court convicted him on two counts of attempted murder with terrorist intent and sentenced him to 26 years and 8 months in prison (the maximum under the charges) and a payment of almost $\$ 3.5$ million in damages to the victims. Sultani, born in Afghanistan and residing in Germany as an asylum seeker, traveled to the Netherlands for the attack because he believed politician Geert Wilders insulted his religion.

- On November 18, the district court of The Hague convicted 27-year-old Pakistani national Junaid Iqbal for planning a terrorist attack on politician Geert Wilders and sentenced him to 10 years in prison. Iqbal traveled to The Hague in August 2018 and posted a video on Facebook threatening to kill Wilders, following Wilders' announcement of organizing a Muhammed cartoon competition.

- On November 25, police arrested two men on suspicion of planning a terrorist attack in the Netherlands. The investigation began in October based on information from the 
General Security and Intelligence Services that the individuals wanted to learn how to make explosives. The individuals reportedly told undercover agents they intended to commit a terrorist attack against an unknown target in the Netherlands before the end of the year using car bombs or suicide vests.

Returned FTFs undergo a threat assessment by the government; some returnees are prosecuted. The government does not actively repatriate FTFs and their children from camps in Syria but escorts back those FTFs who report to a Dutch diplomatic mission. On January 23, the district court in Rotterdam ordered the government to "do everything it can" to ensure that six female former ISIS members, who are currently in Syrian refugee camps, are brought into Dutch custody. The government announced it would incorporate four other women in similar situations in this effort. On November 11, a Dutch court ruled that the government must do everything it can, including seeking U.S. assistance, to repatriate 55 children of FTFs. On November 22, an appellate court overturned this decision. As of December 1, the women were still in camps in Syria.

Countering the Financing of Terrorism: The Netherlands is a member of the FATF and is one of the Cooperating and Supporting Nations of the Caribbean Financial Action Task Force, a FATF-style regional body. Its FIU, the Financial Intelligence Unit - Netherlands, is a member of the Egmont Group and contributes to Europol's financial intelligence team. The Netherlands is also a member of the Defeat ISIS Coalition's CIFG.

In 2019, Dutch courts convicted at least seven persons for financing FTFs in Syria and issued sentences of up to nine months in prison.

The Dutch framework for countering the financing of terrorism applies to all EU-designated terrorist organizations and the UN Security Council ISIL (Da'esh) and al-Qa'ida sanctions regime. As of December 2019, the government's national terrorist watch lists include 139 individuals and four organizations whose assets were frozen.

Countering Violent Extremism: The Netherlands' 2016-2020 National Counterterrorism Strategy contains measures to strengthen communities, build resilience to terrorist radicalization, and prevent persons from becoming FTFs. The strategy prioritizes prevention, among other themes. The government uses a local, multidisciplinary approach for prevention and develops tailored plans of action to intervene with individuals suspected of radicalization.

Community police officers are the cornerstone of the local approach to prevention. Other stakeholders include local governments, with the support of the Office of the National Coordinator for Security and Counterterrorism, the public prosecutor's office, social workers, child protective services, educators, and community leaders. This approach prioritizes the use of preventive measures, including mentoring, counseling, and access to job-training programs and other social services. Similar programs also rehabilitate former terrorists. To counter terrorist messaging, local governments use outreach efforts with community and religious leaders to amplify credible voices.

The Dutch cities of The Hague, Rotterdam, and Utrecht are members of the SCN. 
International and Regional Cooperation: The Netherlands participates in the UN, GCTF, the EU, the CoE, the OSCE, and NATO. The Netherlands handed off its co-chair of the GCTF to Canada on September 23, but the GCTF Administrative Unit remained in The Hague. The Netherlands is on the governing board of the three GCTF-inspired institutions: the International Center of Excellence for Countering Violent Extremism (Hedayah), the International Institute for Justice and the Rule of Law, and GCERF. The Netherlands also participates in the Global Initiative to Combat Nuclear Terrorism.

The Netherlands continued to finance a wide variety of capacity building projects. The Ministry of Foreign Affairs appointed regional security coordinators at six embassies who are dedicated to capacity building to identify terrorist radicalization. The Netherlands is an active participant in Europol's European Counter Terrorism Center and the Counter Terrorism Group (the intelligence services of all EU member states plus Norway and Switzerland) to improve cooperation and information exchange between and among European CT services.

\section{NORTH MACEDONIA}

Overview: North Macedonia cooperated with U.S. CT efforts and was a member of the Global Coalition to Defeat ISIS. With no terrorist attacks in 2019 and no reported departures of its citizens to join ISIS, the main terrorism threat North Macedonia faced consisted of returned FTFs from Syria and Iraq. North Macedonia's authorities assessed that ISIS members and sympathizers maintained a presence in North Macedonia. The National Committee for Countering Violent Extremism and Countering Terrorism (NCCVECT) estimated 156 citizens of North Macedonia have traveled to join terrorist groups in Syria and Iraq. Of that number, 36 were killed, 37 remain, and 83 returned to North Macedonia. The country's authorities acknowledged an unconfirmed number of family members reside in refugee camps in Syria.

2019 Terrorist Incidents: There were no reported terrorist incidents in North Macedonia in 2019.

Legislation, Law Enforcement, and Border Security: North Macedonia's legislative framework is adequate to prosecute individuals and groups suspected of committing or aiding terrorist activities or participating in foreign wars. Low sentencing for terrorism-related offenses remains a challenge.

Six of the seven FTFs repatriated in August 2018 were re-sentenced in November, following the appellate court's decision to return the case to the first instance court. They again pleaded guilty to participation in a terrorist organization, and each received the same six-year sentence. One of the six FTFs continues to contest his remaining charge of membership in a terrorist organization, while the seventh FTF's case has been severed from the others and is delayed as he receives medical treatment.

North Macedonia's law enforcement capacity to proactively detect, deter, and prevent acts of terrorism improved because of numerous training sessions. The Ministry of Interior's (MOI's) newly named "Terrorism and Violent Extremism Sector" continued to take the lead in 
performing law enforcement-related CT functions. In September, the Agency for National Security replaced the Department for Security and Counterintelligence as a distinct entity separate from the MOI. Two major units comprise MOI's "Terrorism" sector - terrorism investigations and explosive ordinance detection and destruction. In 2019, the U.S. Department of State provided numerous training sessions for law enforcement officers, as well as mentorship, and it donated hardware, software, and crime scene forensic tools to the country's law enforcement CT partners. Embassy Skopje supported a "Friendly Patrols" project by mentoring six retired police officers, who trained about 120 active police officers and community members to recognize the early signs of terrorist recruitment and radicalization.

North Macedonia continues to enhance its ability to screen for terrorists as part of a comprehensive approach to border security, with support and cooperation from the United States. In February, North Macedonia committed to implementation of the use of API/PNR data to screen for known or suspected terrorists and/or criminals.

Countering the Financing of Terrorism: North Macedonia is a member of MONEYVAL. North Macedonia's FIU, the Financial Intelligence Office (FIO), is a member of the Egmont Group. In 2019, the government adopted necessary bylaws to the Law on Restrictive Measures, including Guidelines for the Implementation of Financial Restrictive Measures Against Terrorism and Proliferation; a decision for establishment of a coordinative body to monitor implementation of restrictive measures; and a rulebook on maintaining a list of designated persons against whom financial measures for terrorism have been introduced. The FIO, in cooperation with the NCCVECT, prepared guidance for NGOs regarding their exposure risk to terrorism financing. The Council for AML/CFT gathered about 100 representatives from the public and private sectors to update the National Risk Assessment (NRA), using World Bank methodology. The updated NRA and accompanying Action Plan are with the government, awaiting endorsement and then parliamentary approval. Jordan provided the FIO with grant funding to upgrade its software for the exchange of data on designated individuals and entities of terrorism financing concern. The FIO received six suspicious transaction reports for terrorist financing in 2019 and submitted them to relevant institutions for further processing.

Countering Violent Extremism: The government continued to implement the action plan associated with the National CVE Strategy, adopted in March 2018. The NCCVECT assessed the level of implementation as "satisfactory." In partnership with the OSCE, the NCCVECT organized a series of roundtables across the country to raise awareness around the national CT and CVE strategies and action plans. The NCCVECT assisted the multi-stakeholder Community Action Teams established in Kichevo, Gostivar, and Cair (a municipality in the capital city of Skopje), to develop and implement their Action Plans focused on preventing terrorist radicalization and recruitment. With support from the SCN, Kumanovo also established a Community Action Team in September. The municipalities of Aracinovo, Cair, Gostivar, Kicevo, Kumanovo, Ohrid, Struga, and Tetovo are members of the SCN.

In conjunction with international donors, the NCCVECT supported numerous projects focused on recognizing the "early signs of radicalization and building community resilience to terrorist ideas" by training and engaging youth, parents, educators, and law enforcement officers. Among other initiatives, with funding from the U.S. Department of State's CT Bureau, the United States 
supported the NCCVECT through an imbedded expert on countering radicalization and recruitment, and it supported the Women Without Borders' Mothers' Circles program to expand to three additional municipalities. A UK-funded project engaged the family members of convicted terrorism offenders to provide a clearer picture of the challenges these families face and the social assistance needed. The International Organization for Migration is using this analysis to help inform its new program focused on reintegration. Despite these nascent efforts, North Macedonia currently has no reintegration and rehabilitation programs in place, and no humanitarian aid programs are underway to assist returnees.

International and Regional Cooperation: Since the NCCVECT was established in 2017, it has focused on increasing regional cooperation. In 2019, North Macedonia cooperated with other Western Balkan countries on critical infrastructure protection, prison radicalization and the tools available to counter it, and the repatriation of FTFs and their family members. North Macedonia initiated closer cooperation with regional countries' intelligence agencies to share CT-relevant information. With EU support, North Macedonia adopted and signed a Joint CT Action Plan among Western Balkan countries, part of the Western Balkans Six initiative.

\section{NORWAY}

Overview: Norway and the United States maintained good collaboration on CT. Norway's Police Security Service (PST) continued to assess that individuals and groups inspired by "extreme Islamist groups" represented the most significant terrorist threat to Norway. Norway saw an increased level of mobilization and recruitment among REMT groups, which it calls "right wing extremist groups." The PST reintroduced a five-level scale to describe the national terror threat level and set the risk level at 3, which indicates a moderate chance of a terrorist attack taking place.

Norway is a member of the Global Coalition to Defeat ISIS. The government co-sponsored UNSCRs 2178 and 2396 and contributed to the Coalition's five lines of effort, including military personnel support to a capacity-building mission for Iraqi security forces in Anbar, Iraq. In 2019, Norway provided country specific funding of approximately US \$334 million to address the humanitarian crises in Iraq and Syria.

2019 Terrorist Incidents: In August, Philip Manshaus attempted to commit a mass shooting at an Islamic center in a municipality neighboring the capital, Oslo. He entered the mosque when few people were present and was overpowered by a member before being apprehended by police. He is being investigated for terrorism and the murder of his stepsister and is in pretrial detention. The investigation revealed he was active in online forums for white supremacists and inspired by the mass shooting in Christchurch, New Zealand. Following this attack, PST updated its assessment of the likelihood of "right-wing extremists" attempting to carry out terrorist attacks from "unlikely" to "possible."

Legislation, Law Enforcement, and Border Security: Terrorism is a criminal offense in Norway, and it is illegal to conduct or plan to conduct a terrorist attack, receive terrorism-related training, or provide material support to a terrorist organization. In addition, it is a criminal 
offense to travel or intend to travel to fight on behalf of a terrorist organization. The maximum prison sentence for serious terrorism offenses is 30 years.

Norway continued to prosecute individuals for terrorism-related offenses. In separate cases, a Norwegian court convicted a woman of attempting to join a terrorist organization and a man of participating in a terrorist organization. The woman received a prison sentence of two years and nine months, and the man received seven years and three months. In at least one instance, Norwegian officials used the Immigration Act to arrest a white supremacist on the grounds that he could influence others to commit violence.

The Norwegian government changed the Immigration Directorate's guidance so that those possessing or seeking residence permits who have spent time in ISIS-controlled areas or have some affiliation with ISIS or other terrorist networks in Syria and Iraq may have their permits revoked and shall have their applications denied, to the extent consistent with the Norwegian Constitution and International Law.

The PST is responsible for domestic security, including CT activities. The Joint Counter Terrorism Center, a joint analysis cell, includes participants from the PST and the Norwegian Intelligence Service (NIS), the external security service. Both PST and NIS have devoted significant resources to identifying, tracking, and taking action against Norwegian citizens intending to travel to and from Syria or Iraq to fight for terrorist groups.

Norway shares fingerprint information in criminal investigations with the EU and the parties to the Prüm Convention. Norway continued to explore an agreement on sharing PNR data with the EU and is simultaneously developing a national PNR system, which remained in the pilot phase at the end of 2019. Immigration to Norway is facilitated and regulated by the Norwegian Directorate of Immigration, which processes all applications for asylum, visas, family immigration, work and study permits, permanent residence, and travel documents. The Norwegian Immigration Database serves as a central repository for immigration authorities and contains biographic data and facial photos for all applicants for admission. The Norwegian police and the Ministry of Foreign Affairs issue passports that, since 2005, have contained biometric data accessible for review by border security officials. Norway coordinates with INTERPOL and Europol to enhance its vetting processes and has access to the Schengen Information System and the Visa Information System to share and receive information regarding suspected terrorists.

Security measures to protect soft targets in Oslo include physical barriers in the streets of one of the city's main pedestrian thoroughfares and directly outside the neighboring buildings. Measures may be enhanced for specific events. Police at Oslo's Gardermoen Airport are armed on a permanent basis. The government and its underlying agencies continued to implement measures to secure public infrastructure, such as government and defense facilities, against potential terrorist attacks. This followed criticism for slow progress by the National Auditor in 2018. 
Countering the Financing of Terrorism: Norway is a member of the FATF. Norway's FIU, the Financial Intelligence Unit Norway, is a member of the Egmont Group. Norway is a member of the Defeat-ISIS Coalition's CIFG. There were no significant updates in 2019.

Countering Violent Extremism: Norway continued to implement its National Action Plan against Radicalization and Violent Extremism, published in 2014, which is a whole-of government approach to countering terrorist radicalization and recruitment. Priorities include strengthening CVE research, improving national and local cooperation on counter-radicalization efforts, promoting the reintegration of former terrorists, and preventing online recruitment and radicalization. The plan is dynamic and is reviewed regularly with all stakeholders to ensure continued effectiveness. A review process begun in 2019 has been particularly comprehensive because of changes in the threat environment.

Norway coordinates among authorities responsible for managing the release from prison and reintegration of those convicted of terrorism-related offenses. Municipalities considered home to populations and individuals most vulnerable to terrorist radicalization have created action plans for prevention activities. The national government hosts an annual conference on terrorist radicalization, which in 2019 focused in part on racially or ethnically motivated terrorism.

Norway supports the Youth Civil Activism Network. Oslo and Kristiansand are members of the SCN.

International and Regional Cooperation: Norway is active in multilateral fora in efforts to counter terrorism, including NATO, the EU's Radicalization Awareness Network, and the OSCE. In 2019, the OSCE launched a Norwegian-funded handbook on gender perspectives in countering violent extremism and radicalization. Norway provided financial support to the GCTF Working Group on Capacity-Building in East Africa, supported INTERPOL's capacitybuilding programs on border security and rule of law in North Africa and the Sahel, and funded counter-radicalization programs in prisons in Kenya, Indonesia, and Morocco. Norway supports implementation of the UN Secretary-General's Plan of Action to Prevent Violent Extremism and is co-chair with Jordan of the Group of Friends at the UN on preventing violent extremism. Norway is contributing \$1.2 million to the UNOCT for the 2018-2021 period, in partnership with UNDP. Norway provides funding for the International Civil Society Action Network and in 2019 hosted the eighth annual Women, Peace and Security forum, which focused on situational and trends analysis regarding the threat of terrorism and conflict. Norway supports the GCERF.

\section{RUSSIA}

Overview: The Russian Federation continued to prioritize CT efforts in 2019 and remained a target of international terrorist groups, particularly ISIS. Low-level militant terrorist activity remained a problem in Russia's North Caucasus region despite increases in CT activities and political consolidation efforts. 
2019 Terrorist Incidents: On January 11, three apparent terrorists attacked officers of Russia's road patrol service near the village of Agachaul, Karabudakhentsky District in the Republic of Dagestan. The suspects opened fired on law enforcement officers with automatic rifles before being killed by the authorities. The authorities reportedly found additional weapons and ammunition in the suspects' car. Additional attacks included:

- On March 13, two suspects in the Shpakov district in Stavropol opened fire with automatic weapons and threw a grenade when stopped by the Federal Security Service (FSB) for questioning. The suspects were killed onsite. Russian authorities reported the perpetrators were affiliated with ISIS and had been planning a terrorist attack.

- On April 8, there was an explosion at Kolomna, near Moscow. ISIS later claimed responsibility for the attack, which reportedly did not result in any casualties.

- On July 1, a man killed a police officer with a knife at a checkpoint in the AchkhoyMartonovsky district of Chechnya. The police shot and killed the attacker as he threw a grenade at them. ISIS claimed responsibility for the attack.

- On December 19, a Moscow region resident opened fire near the FSB headquarters in Moscow and killed two security officers and wounded four others. The shooter was killed onsite. The attacker was later identified as Yevgeny Manyurov, a 39-year-old former security guard.

Legislation, Law Enforcement, and Border Security: Under the coordination of the National Antiterrorism Committee and with aid from the Ministry of Internal Affairs when appropriate, the FSB performs CT functions. Russia increasingly used its counterterrorism and antiextremism legislation against the political opposition, independent media, and certain religious organizations, including Jehovah's Witnesses, to criminalize the exercise of freedoms of religion or belief, expression, and association.

Russia's FSB Director General Alexander Bortnikov reported in late September that the FSB had identified terrorist cells in 17 regions of the country. He stated that Russian law enforcement had prevented 39 terrorist attacks, killed 32 militants, detained 679 suspects, and dismantled 49 terrorists' cells that were plotting attacks. Notwithstanding those incidents, Bortnikov stated on December 10 that the intelligence services did not allow any terrorist acts in 2019 despite the incidents listed. The Ministry of Internal Affairs reported that those detained in connection to terrorism in 2019 included 14 returning international terrorists.

On November 5, Russian media reported the arrest of a 30-year-old native of Kyrgyz Republic for planning a terrorist attack in Moscow. Media reported the suspect, who confessed to planning an explosion in a crowded area of the nation's capital, was affiliated with a "radical form of Islam.”

Countering the Financing of Terrorism: Russia is a member of FATF and two FATF-style regional bodies: MONEYVAL and EAG. Its FIU, the Federal Financial Monitoring Service (Rosfinmonitoring), is a member of the Egmont Group.

In September, Rosfinmonitoring released for public discussion a draft law to amend Article 6.2 of the federal law "On the Prevention of Criminal Proceeds Legalization and Terrorist 
Financing." The amendment would establish that legal entities are required to take reasonable measures in specific circumstances to prevent the laundering of criminal proceeds and to cooperate with law enforcement agencies on issues related to combating terrorist financing and money laundering.

In December, FATF published a Mutual Evaluation Report that reviewed Russia's compliance with FATF standards and the effectiveness of Russia's AML/CFT system.

Countering Violent Extremism: The government has not committed great attention to countering terrorist radicalization and recruitment in 2019. However, according to NGO reports, Russian government authorities, including the Ministry of Internal Affair's Center for Countering Extremism and the FSB, continue to misuse the country's expansive definition of extremism to curtail freedoms of expression, belief, assembly, and association.

International and Regional Cooperation: Russia participated in several joint CT exercises, including the Tsentr 2019 exercise from September 16 to 21, with China, India, Pakistan, Kazakhstan, Kyrgyz Republic, Tajikistan, and Uzbekistan. Russia also promoted the Collective Security Treaty Organization as a forum for international CT cooperation and conducted the Combat Brotherhood-2019 exercise from October 21 to 29. Russia is a member of the GCTF and an active participant in several multilateral organizations, including the UN, OSCE, the East Asia Summit, APEC, the Shanghai Cooperation Organization, and the ASEAN Regional Forum. On September 5 and 6, the Russian Ministry of Foreign Affairs organized the International Conference on Countering Illicit Trafficking in Arms in the Context of Fighting International Terrorism. Russia also hosted the 18th Meeting of Heads of Special Services, Security Agencies, and Law-Enforcement Organizations in Sochi on October 16 and 17.

\section{SERBIA}

Overview: With no terrorist attacks in 2019 and low levels of ISIS recruitment activities, the main terrorism concerns in Serbia remain the potential movement of money and weapons through the region, recruitment and return of FTFs, the revitalization of terrorist ideologies, and opportunities for self-radicalization to terrorism, including racially and ethnically motivated terrorism. Serbia has built on its efforts to counter terrorism and continues cooperation with the United States and international partners. Serbia is a member of the Global Coalition to Defeat ISIS.

Terrorist Incidents: There were no reported terrorist incidents in Serbia in 2019.

Legislation, Law Enforcement, and Border Security: Serbia's criminal code criminalizes terrorism-related offenses, including international terrorism, incitement, recruitment, using a deadly device, destruction and damage to a nuclear facility, terrorist financing, and terrorist association. The criminal code also outlaws unauthorized participation in a war or armed conflict in a foreign country and prescribes incarceration from six months to eight years, with penalties increased to 10 years for citizens who organize, train, or fund a foreign armed conflict. Although UNSCR 2396 mandates that member states develop systems to screen PNR data, currently API and PNR screening programs are not in place in Serbia. Serbia's Civil 
Aviation Directorate is integrating with the European Common Aviation Area and cooperates with international partners to enhance capacities in accordance with UNSCR 2309.

Amendments to the criminal code passed in May 2019 have criminalized travel abroad to prepare for, train for, plan, or participate in the commission of terrorist acts. The amendments expand the criminal offense of terrorist financing by, among other things, specifying direct or indirect fundraising or funds collection for the purpose of financing the commission of terrorist acts. The amendments also introduce a sentence of life imprisonment for the most serious forms of terrorism.

There has been no change to the way the courts address terrorism. Current legislation stipulates that the Belgrade Higher Court's Special Department for Organized Crime hears terrorismrelated offenses and the Organized Crime Prosecutor's Office prosecutes them. The Belgrade Appellate Court's Special Department for Organized Crime hears appeals.

Serbia's law enforcement capacities need improvement but are progressing. The Criminal Police Directorate's Service for Combating Terrorism and Extremism (TES) works on terrorism detection, deterrence, and prevention. Serbia's Operational Working Group consists of TES, the Security Information Agency, and the Prosecutor's Office. Soft targets are required to have terrorism contingency plans, with TES officers providing consultation and oversight.

The Serbian Border Police's System to Check Persons and Vehicles (SZPLIV) screens passengers and vehicles at all border crossings and other ports of entry. SZPLIV verifies the validity of travel documents through basic indicative security elements, collects biographic and biometric data, checks visa status, searches national and international databases, and stores the information. However, data transmission to the central system can take days.

Countering the Financing of Terrorism: Serbia is a member of MONEYVAL, a FATF-style regional body, and has observer status in the Eurasian Group on Combating Money Laundering and Financing of Terrorism (EAG). Its FIU, the Administration for the Prevention of Money Laundering, is a member of the Egmont Group.

In June, the FATF removed Serbia from monitoring under FATF's ongoing global AML/CFT compliance process, commonly referred to as the FATF "grey list." In October, the Government of Serbia proposed legislative amendments to the Law on the Prevention of Money Laundering and Financing of Terrorism to further align Serbia's existing AML/CFT regime with recommendations of MONEYVAL and the EU's Fifth AML Directive. In December, Serbia opened Chapter 4 of the EU acquis (Free Movement of Capital), which will require Serbia to complete further legislative alignment with the acquis and international standards, as well as demonstrate, through a track record, an improved administrative capacity to implement and enforce AML and CFT legislation.

Countering Violent Extremism: Serbia is implementing its National Strategy for the Prevention and Countering of Terrorism for the Period 2017-2021 and accompanying Action Plan, which seeks to identify early factors leading to terrorist radicalization, enhance the security of its citizens, and intercept threats from social media activities. The Serbian intergovernmental 
CT working group meets regularly. In 2019, Serbia appointed the director of police at the Ministry of Interior as the national coordinator for countering terrorist radicalization and recruitment. The government took some steps to counter violence against minorities.

Bujanovac, Novi Pazar, Preševo, and Tutin are members of the SCN.

International and Regional Cooperation: Serbia is engaged in some regional and international cooperation on CT issues. The Ministry of the Interior and the Security Information Agency cooperate with INTERPOL and Europol on CT activities, including watchlists. In 2019, INTERPOL issued red notices at Serbia's request for three FTFs who are Serbian citizens. Serbia, a participant in NATO's Partnership for Peace, assisted in NATO training of Iraqi military medical personnel as part of counterterrorism efforts and routinely participates in international law enforcement training. Police officers of the Ministry of Internal Affairs participated in training or study visits, including to the Special Task Force in Rome, which is part of the Italian Carabinieri, as well as to the Europol Referral Unit in The Hague.

In 2019 the OSCE deployed a mobile training team (represented by border officers from $\mathrm{BiH}$, Greece, North Macedonia, the United States, and INTERPOL) in Belgrade to deliver interactive training on the identification of FTFs for Serbian border officials. Sessions included training on employing API and PNR systems and travel document security.

Serbia has well-developed bilateral border security cooperation programs with Bulgaria, Hungary, and Romania, and a Tri-Border partnership with Bosnia and Herzegovina and Croatia. Serbian law enforcement agencies routinely engage with Albania, North Macedonia, and Montenegro.

\section{SPAIN}

Overview: Spain remained on "high" national alert for terrorism throughout 2019 for the fifth year in a row, and Spanish authorities continued to arrest individuals suspected of planning terror attacks; facilitating terrorist financing; and engaging in ISIS- and al-Qa'ida-related recruitment and radicalization, both online and in their communities. Spanish CT cooperation with the United States was excellent. Spain maintained its contribution to the Global Coalition to Defeat ISIS, with up to 550 personnel deployed to Iraq throughout the year in military and police training missions. Spain continued to exercise leadership in regional and global CT fora, including the GCTF and the 5+5 Defense Initiative.

2019 Terrorist Incidents: There were no known terrorist incidents reported in Spain during the year.

Legislation, Law Enforcement, and Border Security: The Spanish government published its first National Strategy Against Terrorism to unify and update its strategy to prevent, combat, and counteract terrorist threats, replacing the 2012 Comprehensive Strategy Against International Terrorism and Radicalization. The Ministry of Interior, through the Center for Intelligence against Terrorism and Organized Crime (CITCO), with contributions from the Ministries of Defense, Foreign Affairs, and Justice, developed the document to align with the Counter- 
Terrorism Strategies of the EU and the UN with four pillars: Prevent, Protect, Pursue, and Prepare the response. The strategy is in force for four years.

The Spanish criminal code punishes any act of "collaboration with the activities or purposes of a terrorist organization," including promotion of terrorism on social media, self-radicalization on the internet, training remotely, operating without clear affiliation, or traveling in support of nonstate terrorist actors. As of November 2019, Spanish authorities reported that police had undertaken 32 cunterterrorist operations and detained 58 suspects for the year. Significant law enforcement actions related to CT included:

- On February 4, the Spanish Ministry of Interior announced the breakup of a terrorist network in Spanish prisons, led by five Moroccan nationals who sought to recruit other prisoners to pledge allegiance to ISIS. The five suspects, ranging in age from 25 to 68 , had been serving sentences since 2013 and are believed to have been radicalized in prison. A prison official who allegedly took bribes from the network was also arrested, along with a man and woman in the Madrid suburb of Alcorcón who allegedly provided the network with material support. The suspects threatened and harassed other prisoners for diverging from religious orthodoxy and directly instructed other prisoners to commit acts of terrorism. They claimed to be in contact with ISIS leaders who could facilitate financial compensation to the prisoners' families in exchange for conducting attacks.

- On September 23, Spanish Civil Guard agents arrested nine individuals for allegedly stockpiling explosive precursors and planning to commit violence on or around the anniversary of the October 1, 2017, illegal Catalan independence referendum, and/or in response to the conviction and sentencing of jailed pro-independence leaders. Authorities eventually charged seven of those arrested with membership in a terrorist organization, manufacture and possession of explosives, and conspiracy to commit mayhem. The investigating court subsequently released several of the accused on bail because they were not primary actors in the conspiracy.

- On October 8, Spanish Police arrested a 23-year-old Spanish citizen of Moroccan origin for alleged membership in ISIS. He was allegedly the coordinator in Spain of Muntasir Media, an unofficial platform for disseminating propaganda supporting ISIS and promoting terrorism. Officials found chemical precursors for explosives at his residence along with instructions for making bombs. He had also assembled lists of possible targets for attack. Authorities charged him with advocating terrorism and making terrorist threats.

Countering the Financing of Terrorism: Spain is a member of the FATF and has observer or cooperator status in the following FATF-style regional bodies: the Caribbean Financial Action Task Force (CFATF), the Financial Action Task Force of Latin America (GAFILAT), and the Middle East and North Africa Financial Action Task Force (MENAFATF). Spain maintained funding levels for its FIU, the Executive Service for the Prevention of Money Laundering and Monetary Offenses, which is a member of the Egmont Group. Spain is a member of the Defeat ISIS Coalition's CIFG.

The Spanish government has proposed automatically applying future UNSC terrorism financing sanctions in Spain, rather than awaiting the transposition of the sanctions by the EU. On June 
18, the Spanish National Police, in collaboration with Europol, arrested 10 suspects of Syrian origin as part of a large CT financing operation involving 350 agents across Madrid, Toledo, and Valencia. The accused allegedly had links to al-Qa'ida operatives in Syria and were detained for belonging to a criminal organization, collaborating with a terrorist organization, terrorist financing, money laundering, tax fraud, document falsification, and facilitating illegal immigration.

Countering Violent Extremism: Spain continued implementation of its national CVE plan, developed in 2015 and led by CITCO. It identifies potential for terrorist radicalization and recruitment down to census district level using an algorithm based in socioeconomic factors and seeks to build partnerships at the local level between civil society leaders from vulnerable communities and representatives of law enforcement and other public services. While Interior Minister Fernando Grande-Marlaska had announced an effort to "revamp" the plan in October 2018, no amended version has yet been issued publicly. According to the plan, Barcelona is considered the highest risk area for jihadist terrorist activity, though police made more terrorismrelated arrests near Madrid (23 versus seven in Barcelona) than any other city. The Spanish cities of Fuenlabrada and Malaga are both members of the SCN.

International and Regional Cooperation: Spain is a founding member of the GCTF and supports CT initiatives in the UN, CoE, NATO, and OSCE. Spain maintained forces throughout 2019 in EU training missions in Mali and Somalia. Spain continues to support the 5+5 Defense Initiative bringing together European (France, Italy, Malta, Portugal, Spain) and North African (Algeria, Libya, Mauritania, Morocco, Tunisia) countries to build capacity on CT, maritime and aviation security, and disaster management. Spain cooperated with regional partners on CT investigations and arrests.

\section{SWEDEN}

Overview: There were no terrorist attacks in 2019. The Swedish Security Service annual report stated "the [terrorist] threat remains largely at the same level as a year ago, although very few individuals are likely to have the intent to carry out attacks in Sweden." The report further stated the threat to Sweden from "Islamist-motivated actors" had not changed significantly from last year; however, "xenophobic and white supremacist groups" were increasing in size and collaborating more frequently with one another. At the end of 2019, the national alert level remained Level 3 (elevated threat, no evidence of planning) on a scale of 5 (attack imminent, evidence of planning).

The government continued efforts to strengthen its CT framework. In October, the government proposed draft legislation that would criminalize collaboration with terrorist organizations and another draft law that would authorize law enforcement access to encrypted data on computers and mobile devices. Parliament will debate the laws in 2020. In November, the Terrorist Investigation Commission completed its systematic review of criminal laws pertaining to terrorism. The report proposed that the government draft a comprehensive, updated terrorism law to replace the existing patchwork of laws. 
Sweden is a member of the Defeat-ISIS Coalition. In addition to being a leader in humanitarian support to ISIS-affected communities, Sweden deployed 70 military trainers to Iraq in support of Defeat-ISIS efforts.

2019 Terrorist Incidents: There were no terrorist incidents reported in Sweden in 2019.

Legislation, Law Enforcement, and Border Security: In April, new legislation gave the Swedish Coast Guard increased authorities for maritime law enforcement. The new law also extended the Coast Guard's mandate to include support for the National Police in its efforts to combat crime and strengthen national security.

In August, the terrorism trial that had begun in December 2018 of five Uzbek and one Kyrgyz nationals concluded. All six defendants were convicted of terrorism financing but then released for time served. The prosecution requested expulsion in all cases, but the Migration Court of Appeal ruled that current conditions in the defendants' home countries made it impossible to deport them. In October, the government requested the deportation of six "radical" imams who had been detained by the Swedish Security Service. The Migration Court of Appeal ruled the men could not be deported as they risked persecution in their home countries.

Sweden is party to the EU's identity verification and border management tools such as the Schengen Information System and the Visa Information System. Sweden collects and uses API, and some PNR, and exchanges information with other members states on irregular immigration and border control. The EU PNR directive came into force on August 1, 2018. Sweden used the "serious threat to public policy or internal security" justification permitted under the Schengen Border Code to unilaterally prolong the temporary border controls first introduced in 2015 in response to the massive influx of asylum seekers until May 12, 2020.

Countering the Financing of Terrorism: Sweden is a member of FATF. Its FIU, the National Financial Intelligence Service, is a member of the Egmont Group. There have been no changes since 2018. There were no significant updates in 2019.

Countering Violent Extremism: The National Center for Preventing Violent Extremism under the Ministry of Justice coordinated efforts among government ministries, local municipalities, and civil society organizations to share risk assessments, action plans, best practices, and lessons learned. Malmo and Stockholm are members of the SCN.

International and Regional Cooperation: Sweden is a member of the EU and supports CT efforts in regional and multilateral organizations, including the European Commission's Radicalization Awareness Network, the EU-9 (focusing on FTFs), the Counter-Terrorism Group, the Police Working Group on Terrorism, and Europol.

Sweden funded international CT capacity building projects through development assistance from the Swedish International Development Cooperation Agency (SIDA), funding to the UN Office on Drugs and Crime-Terrorism Prevention Branch, and funding to the OSCE. Sweden supported the EU's work with capacity-building projects in prioritized countries and regions, such as Pakistan, Yemen, the Horn of Africa, the Maghreb, and the Sahel. 
Sweden provided 200 trainers to the UN MINUSMA and recently extended the mission through 2020. Sweden participated in the Resolute Support Mission in Afghanistan with 25 service members and recently extended the mission through 2020. Sweden was a member of the DefeatISIS Coalition and made humanitarian contributions to ISIS-affected populations in Iraq in addition to development aid funding to Iraq (\$105 million for 2017-2021). Sweden extended its deployment of 70 military trainers in Iraq in support of Coalition efforts until the end of 2020. Sweden contributed humanitarian support for northern Syria ( $\$ 52$ million since the beginning of the year). Since 2016, Sweden also implemented a regional crisis strategy for Syria (\$190 million) that included resilience support for groups affected by ISIS's progress. On October 17, the government announced an additional $\$ 10.5$ million for further efforts in northeast Syria.

\section{TURKEY}

Overview: Turkey continued its efforts to defeat terrorist organizations both inside and outside its borders, including the PKK and ISIS. Turkey remained an active contributor in international CT fora, including the GCTF.

Turkey is a source and transit country for FTFs seeking to join ISIS and other terrorist groups fighting in Syria and Iraq. Turkey is an active member of the Global Coalition to Defeat ISIS, co-chairs the Defeat-ISIS Coalition FTF Working Group, and continued to provide access to its airspace and facilities for Coalition CT operations in Iraq and Syria. According to public data, as of November, Turkey's "Banned From Entry List" included about 76,000 individuals. Since 2011, Turkey has repatriated more than 7,800 FTFs from more than 100 countries. As part of a new push to return suspected ISIS members and family members to their home countries, between mid-November and early-December 2019, the Turkish government deported or denied entry for more than 70 individuals for alleged terrorism. The Ministry of Interior reported that, as of December 9, there were 1,174 ISIS members and 115 al-Qa'ida members in Turkish custody.

The PKK continued to conduct terrorist attacks in Turkey and against Turkish interests outside of Turkey. Turkey's security forces conducted operations domestically along with military operations in northern Iraq and northern Syria. International Crisis Group, an NGO, assessed that, in the first 11 months of the year, 26 civilians, 82 security force members, and 343 PKK militants were killed in Turkey's eastern and southeastern provinces in PKK-related incidents. Detentions and arrests of individuals suspected of aiding or having sympathies toward the PKK, including some elected politicians, continued in 2019. The government continued to restrict some freedoms and elements of the country's rule of law system under broad counterterrorism legislation. Prosecutors used a broad definition of terrorism and threats to national security to file criminal charges against and prosecute a broad range of individuals, including journalists, opposition politicians, activists, and others critical of the government. 
Two Turkish National Intelligence Organization (Milli Istihbarat Teskilatı) officers who were kidnapped in 2017 by the PKK in northern Iraq, remained missing at year's end. In July, attackers presumed to be part of the PKK assassinated a Turkish diplomat in a café in Erbil, Iraq. As a CT partner of the United States, Turkey received U.S. assistance to address the terrorist threat posed by the PKK in 2019.

In the aftermath of the July 2016 coup attempt, the Turkish government labeled the movement of self-exiled Fethullah Gulen as the "Fethullah Terrorist Organization" ("FETO"). "FETO" is not a designated terrorist organization in the United States. The government continued to detain and arrest Turkish citizens, as well as foreign citizens resident in Turkey - including U.S. citizens and locally employed staff at the U.S. Mission to Turkey - for alleged "FETO" or terrorismrelated links, often on the basis of scant evidence and minimal due process. The government also regularly sought to extradite Turkish citizens resident abroad on terrorism related charges to prosecute them at home for alleged links to "FETO." The government also continued to dismiss military, security, and civil servants from public office in 2019. Since the 2016 failed coup attempt, the government has dismissed or suspended more than 130,000 civil servants and members of the armed forces from public office, arrested or imprisoned more than 80,000 citizens, and closed more than 1,500 NGOs for alleged "FETO" links.

2019 Terrorist Incidents: Several terrorist incidents occurred in 2019:

- On July 5, a roadside bomb struck a car in Reyhanli, killing both passengers and a bystander. All three were reportedly Syrian citizens.

- On September 12, a roadside bomb struck a bus carrying workers from the Ministry of Agriculture and Forestry, killing seven and wounding 13 in Diyarbakir province's Kulp district. The government blamed the PKK for the attack.

- On September 25, an IED targeting a police transport van exploded in Adana, wounding five. The government blamed the banned Marxist-Leninist Communist Party for the attack.

- In October, during Turkey's military Operation Peace Spring into Syria against the People's Protection Units (YPG), 13 civilians in Turkey were killed by cross-border shelling from Syria; the Turkish government attributed these to the YPG, which Turkey considers the Syrian arm of the PKK, a designated FTO.

Legislation, Law Enforcement, and Border Security: Turkey has a broad definition of terrorism that includes crimes against constitutional order and internal and external security of the state. The law criminalizes expression that justifies, praises, or incites persons to use coercion or violent methods used by a terrorist organization. The government regularly invoked the law to criminalize the exercise of freedom of expression, freedom of assembly, and other human rights. According to the Ministry of Interior, authorities referred more than 10,000 social media accounts to judicial authorities for alleged terrorist-related propaganda in the first quarter of the year alone, with more than 3,600 users facing legal action for their social media activities. Turkey has advanced law enforcement capacity to combat terrorism, and efforts continue to streamline interagency information sharing. 
The government announced in October that Turkey would take custody of ISIS members and their families in Turkish-controlled areas within Syria. The Ministry of Foreign Affairs said that it would work with countries of origin and international organizations to rehabilitate spouses and children who had not been involved in crimes and would support efforts by countries of origin to repatriate, prosecute, and rehabilitate all FTFs in Syria and their families members. Turkey sometimes deports suspected FTFs without providing advance notice or relevant derogatory information to the destination countries. Following a November 11 deadline imposed by the Ministry of Interior for home countries to begin repatriation of their FTF citizens, at least some FTFs were repatriated over the explicit objections of their home countries.

Countering the Financing of Terrorism: Turkey is a member of the FATF. Its FIU, the Financial Crimes Investigation Board (MASAK), is a member of the Egmont Group. Turkey is also a member of the Defeat ISIS Coalition's CIFG. In December, FATF published a Mutual Evaluation Report that reviewed Turkey's compliance with FATF standards and the effectiveness of Turkey's AML/CFT system and found serious shortcomings. To address these issues, MASAK has embarked on an action plan, which FATF will review at the end of the year.

Countering Violent Extremism: The Turkish National Police (TNP) undertakes social projects, activities with parents, and in-service training for officers and teachers. Programs prepare medical, community, and religious officials to intervene to undermine terrorist messaging and to prevent recruitment. The Ministry of Justice implements some rehabilitation and reintegration programs for convicts and former criminals. The Ministry of Interior claimed in December that it has been in contact with the family members of more than 5,300 PKK members in Turkey and abroad and had used these connections to convince more than $600 \mathrm{PKK}$ members to surrender.

Turkey's Religious Affairs Presidency (Diyanet) reports that it works to undermine terrorist messaging by promoting what it sees as an "inclusive" version of Islam. All Hanafi Sunni imams in Turkey officially must be employees of Diyanet.

The city of Antalya is a member of the SCN.

International and Regional Cooperation: Turkey is a member of the UN, NATO, the CT Committee for the CoE, and the Global Coalition to Defeat ISIS, and it co-chairs, with Kuwait and the Netherlands, the Defeat-ISIS FTF Working Group. Turkey hosted two meetings of the FTF Working Group in Ankara during the year. Turkey regularly participates in GCTF meetings and initiatives. Turkey also contributes to the International Institute for Justice and the Rule of Law, a GCTF-inspired institution, and provides expert support to assist training for judges and prosecutors handling terrorism cases. Turkey participates in OSCE expert meetings on the Prevention of Violent Extremism and Radicalization that Lead to Terrorism organized by the OSCE Office of Democratic Institutions and Human Rights and the OSCE Secretariat.

Turkey has bilateral security cooperation agreements with more than 70 countries. The TNP contributes to CT capacity-building programs of partner countries and offers specialized international law enforcement training in a variety of sectors, including CT. 


\section{UNITED KINGDOM}

Overview: The UK remains one of the strongest and most able U.S. partners in the global fight against terrorism. CT cooperation with the UK is excellent.

Throughout most of 2019, the terrorism threat level in the UK was at the second-highest rating (severe). In early November 2019, the UK lowered the threat level to substantial, meaning the threat of an attack was reduced from "highly likely" to "likely." UK officials categorize Islamist terrorism as the greatest threat to national security, though officials identify a rising REMT threat, which they refer to as "extreme right-wing" terrorism. In 2019, the UK government transferred responsibility for investigations and operations to counter REMT from local police to the national-level Security Service (MI5). Since March 2017, police and security services have disrupted 15 Islamist and seven REMT plots.

The threat level for Northern Ireland-related terrorism within Northern Ireland, set separately from England, Scotland, and Wales, remains severe. In November 2019, the four-member Independent Reporting Commission published the second of four annual reports assessing that paramilitarism "remains a stark reality of life" in Northern Ireland. The report noted that the absence of an executive and functioning legislative assembly since the collapse of Northern Ireland's devolved government in January 2017, as well as the "continuing uncertainty regarding Brexit," have made efforts to end paramilitarism "immeasurably more difficult."

As a partner in the Global Coalition to Defeat ISIS, the UK continued to contribute to stabilization efforts in Iraq and northeastern Syria. Countering ISIS remains one of the UK's top CT priorities, and the UK is working with regional partners to develop border infrastructure, watchlists, and biometric capabilities to counter FTF movement.

2019 Terrorist Attacks: The UK suffered one terrorist attack in November 2019, in which a convicted terrorist who was out on parole killed two people with a knife at an event highlighting education programs for violent offenders. In addition, in October, an assailant stabbed three people at a shopping mall in Manchester. The UK government initially described the attack as terrorism, but later reclassified it as a mental health incident.

Legislation, Law Enforcement, and Border Security: Following the June 2018 release of the UK's CONTEST CT strategy, Parliament passed legislation granting the Home Office and law enforcement entities additional authorities in February 2019.

The Counterterrorism and Border Security Act of 2019 went into effect on April 12 and included several provisions that enabled implementation of the new CONTEST strategy, including one allowing the Home Office to make it a criminal offense for UK citizens to travel to or remain in any geographic area designated by the government as "necessary to protect the public from terrorism." To date, the UK has not formally designated any areas. 
The Act also grants UK police, immigration, or customs officers the authority to stop, search, question, and detain individuals at a UK border area to determine whether they are "engaged in hostile activity." As of December 2019, UK law enforcement authorities were coordinating on implementation guidance for this new authority.

In December 2019, the UK General Election resulted in a large majority for Prime Minister Boris Johnson's Conservative Party in Parliament. PM Johnson has publicly called for longer sentences without the option for parole for convicted terrorist offenders and announced his intent to recruit 20,000 new police officers nationwide.

According to Home Office figures, UK law enforcement agencies made 266 arrests for terrorism-related activity from January through June 2019. As a result, 63 individuals were charged with terrorism-related offenses. The Metropolitan police say there are about 800 active investigations involving about 3,000 individuals. From July 2018 through June 2019, the UK convicted 50 people of terrorism-related offenses, and currently has more than 200 people in custody. Of those convicted, 76 percent received sentences of less than 10 years. Three were sentenced to life in prison.

The UK uses advanced biometric screening at some points of entry and utilizes biometrics for vetting during the visa process; however, some ports of entry, such as ferry ports, have no biometric screening. In 2019, the UK expanded the use of e-gate technology at major airports to include all Five Eyes travelers, as well as those from Japan, Singapore, South Korea, and travelers from the European Economic Area. E-gate incorporates facial recognition technology to match travelers with data recorded in the e-chip of eligible passports.

Countering the Financing of Terrorism: The UK is a member of FATF and has observer or cooperating status in the following FATF-style regional bodies: observer of APG, observer of ESAAMLG, observer of MENAFATF, and a cooperating and supporting nation of CFATF. Its FIU, UK Financial Intelligence Unit, is also a member of the Egmont Group. The UK is also a member of the Defeat ISIS Coalition's CIFG.

The 2018 Sanctions and Anti-Money Laundering Act provides the legal framework to implement sanctions after the UK left the EU. In March 2019, under the Act, three statutory instruments were laid before Parliament that will ensure continuity of the UK's counter terrorism sanctions obligations.

As of June 2019, the UK had \$91,237 of terrorist assets frozen under EU Regulation 881/2002, which implements the UN Security Council ISIL (Da'esh) and al-Qa'ida sanctions regime, and an additional \$11,719 frozen under the Terrorist Asset Freezing Act 2010. It also has \$23,448 frozen under Council Regulation (EU) No 2580/2001.

Countering Violent Extremism: In October 2019, the Commission for Countering Extremism (CCE), a non-statutory expert committee of the Home Office, published a report calling for an overhaul of the UK's approach to "extremist behavior," with an emphasis on what it defines as "hateful extremism." The CCE operates independently and recommended that the Home Secretary chair a new task force charged with formulating a "victim-centered" strategy. 
In April 2019, the UK released the Online Harms White Paper, announcing its intent to establish in law a new duty of care for technology companies toward users for broadly scoped "harmful content" online, which will be overseen by an independent regulator. Under this potential future law, companies and their senior executives will be held to account, including through criminal prosecution, for addressing a sweeping range of online content, including terrorist use of the internet, extremist content, disinformation, cyberbullying, and child sexual exploitation and abuse.

Birmingham, Derry/Londonderry, Leicester, London, Luton, and Manchester are members of the SCN.

International and Regional Cooperation: The UK continued to strongly support CT efforts in regional and multilateral organizations, as well as through the GCTF. The UK is also a key member of the Five Country Ministerial, which promotes multilateral ministerial dialogue on border security and counter-terrorism issues. The UK also cooperates with other OSCE participating states in the fight against terrorism.

\section{THE MIDDLE EAST AND NORTH AFRICA}

Overview: Although significant terrorist activities and safe havens continued to persist in the Middle East and North Africa throughout 2019, the Global Coalition to Defeat ISIS and its local partners achieved important milestones, to include liberating the remaining territory held by ISIS in Syria and the successful raid against ISIS emir Abu Bakr al-Baghdadi. Given the collapse of its so-called "caliphate," remnants of ISIS in Iraq and Syria reverted to clandestine tactics - a trend expected to continue. Beyond Iraq and Syria, ISIS branches, networks, and supporters across the Middle East and North Africa remained active in 2019, including in Libya, the Arabian Peninsula, the Sinai Peninsula, Tunisia, and Yemen. Al-Qa'ida (AQ) and its affiliates, as well as Iran's Islamic Revolutionary Guard Corps-Qods Force (IRGC-QF) and Iran-backed terrorist groups, also remained active throughout the region.

ISIS continued its terrorist campaign in the Sinai through its branch ISIS-Sinai Province (ISIS$\mathrm{SP}$ ), and terrorist groups in Egypt carried out more attacks than in recent years. Of note, ISIS-SP was the first ISIS affiliate to swear allegiance to the new ISIS self-proclaimed caliph following Baghdadi's death. In the Maghreb, counterterrorism efforts and operations by Algeria, Morocco, and Tunisia thwarted the activities of ISIS and other terrorist groups. Algerian armed forces and internal security forces published figures showing an increase in arrests of terrorists or terrorist suspects compared with 2018, and Tunisia increased its successful CT operations, including the killing of Jund al-Khilafah's leader. In Libya, nonstate actors conducted ground operations to neutralize the threat posed by ISIS and al-Qa'ida in the Islamic Maghreb (AQIM) fighters and facilitators. The United States conducted precision airstrikes targeting ISIS cells in southern Libya, disrupting the group's organizational presence in the South and eliminating key ISIS personnel. Most terrorist attacks in Libya during the year were conducted by ISIS.

Despite setbacks, AQ remained resilient and actively sought to reconstitute its capabilities and maintain safe havens amid fragile political and security climates, particularly in Egypt, Libya, 
Syria, and Yemen. For example, AQ and AQ-affiliated groups continued to operate in Idlib province in northwest Syria and AQ-aligned Ansar al-Islam also posed a threat in Egypt.

In Yemen, al-Qa'ida in the Arabian Peninsula (AQAP) and ISIS's Yemen branch continued to exploit the security vacuum created by the ongoing conflict between the Republic of Yemen Government and Iran-backed Houthi militants, while also contending with each other. Additionally, the IRGC-QF and Hizballah continued to take advantage of the conflict to destabilize the region, including by providing weapons and training to Houthi militants who committed attacks against neighboring states. AQAP used its tribal connections and public discontent with the Iran-backed Houthis to recruit new members, conduct attacks, and operate in areas of southern and central Yemen with relative impunity, although CT operations eliminated key leaders, pushed the group out of certain areas, and pressured the group's networks. Though significantly smaller than AQAP, ISIS's Yemen branch engaged in operations against AQAP and continued to claim attacks against Yemeni security forces and civilians, as well as Iranbacked Houthis.

Iran continued to use its IRGC-QF to advance its interests abroad, providing cover for intelligence operations, creating instability, and fomenting violence in the Middle East. In April, the U.S. Secretary of State designated the IRGC, including the Qods Force, as an FTO for the IRGC's continued support to and engagement in terrorist activity around the world. This was the first time the United States ever designated part of another government as an FTO, reflecting that the Iranian regime is unique in using terrorism as a basic tool of its statecraft.

Among other malign activities, in September, Iran targeted some of the Kingdom of Saudi Arabia's most important oil-processing facilities, and Iran also continued to acknowledge the active involvement of the IRGC-QF in the conflicts in Iraq and Syria, the latter in support of the Assad regime. Through the IRGC-QF, Iran continued its support to several U.S.-designated terrorist groups, providing funding, training, weapons, and equipment. Among the groups receiving support from Iran are Hizballah, Hamas, Palestine Islamic Jihad, Kata'ib Hizballah $(\mathrm{KH})$ in Iraq, and al-Ashtar Brigades in Bahrain. Iran also provided weapons and support to Shia militant groups in Iraq, to the Houthis in Yemen, and to the Taliban in Afghanistan. In December, KH launched a rocket attack on an Iraqi military base hosting U.S. and Coalition forces, killing one American civilian contractor and wounding several U.S. and Iraqi service members. In an immediate response to that attack, the United States carried out precision strikes against five targets associated with KH in Iraq and Syria. On December 31, Iran instigated an attack by demonstrators, including Iran-backed terrorists and militia members, on the U.S. Embassy in Baghdad, which resulted in damage to embassy property.

Countries in the Gulf region continued to take important steps to combat terrorism. Following the third U.S.-Qatar Counterterrorism Dialogue in November, the two governments declared fulfillment of their July 2017 Memorandum of Understanding largely complete and committed to set shared counterterrorism priorities for 2020. Saudi Arabia and the United States continued to co-lead the Terrorist Financing Targeting Center (TFTC), an initiative founded in 2017 to increase U.S.-Gulf multilateral collaboration to counter terrorist financing. In 2019, TFTC members imposed sanctions against individuals and entities affiliated with the Iranian regime's terror-support networks in the Middle East. The ongoing rift between Qatar on one side and 
Saudi Arabia, the United Arab Emirates, Bahrain, and Egypt on the other continued to strain regional cooperation and unity of effort, particularly on countering Iranian threats.

In the Levant, Jordan and Lebanon both remained committed partners to the Global Coalition to Defeat ISIS. Several terrorist groups, most notably Hizballah, continued to operate in Lebanon throughout the year. Hizballah remained Iran's most powerful terrorist partner and the most capable terrorist organization in Lebanon, controlling areas across the country. Iran's annual financial backing to Hizballah - which in recent years has been estimated at $\$ 700$ million accounts for the overwhelming majority of the group's annual budget. Hizballah's presence in Lebanon and Syria continued to pose a threat to Israel. Israel published information in August about Hizballah's efforts to produce precision-guided missiles (PGMs) within Lebanon. While Hizballah said it possessed enough PGMs for a confrontation with Israel, it denied missiles were being developed in Lebanon. Israel also uncovered and destroyed multiple tunnels dug by Hizballah under the border into Israel that could have been used for terrorist attacks between December 2018 and January 2019. Although Palestinian terrorist groups in Gaza and the West Bank continued to threaten Israel, Israeli and Palestinian Authority security forces continued their coordination in the West Bank in an effort to mitigate violence.

\section{ALGERIA}

Overview: The United States and Algeria built on their CT partnership through regular dialogue and exchanges of technical expertise. Algeria continued its significant efforts to prevent terrorist activity within its borders and remains a difficult operating environment for terrorist groups. Algerian armed forces and internal security forces published figures that showed continued pressure on terrorist groups. In 2019, the Algerian government increased the number of arrests of terrorists or terrorist supporters compared with the previous year and undertook a comparable number of operations to destroy arms and terrorist hideouts. Some analysts assessed that Algeria's steady drumbeat of sweeping operations substantially diminished the capacities of terrorist groups to operate within Algeria. AQIM, AQIM-allied groups, and ISIS's Algeria branch - including elements of the local group known as Jund al-Khilafah in Algeria (or Soldiers of the Caliphate in Algeria) - remained in the country but were under considerable pressure by Algerian security authorities. These groups aspired to impose their interpretations of Islamic law in the region and to attack Algerian security services, local government targets, and Western commercial interests. Terrorist activity in Libya, Mali, Niger, and Tunisia - as well as human, weapons, and narcotics trafficking - contributed to the overall threat, particularly in border regions.

Algeria's domestic efforts to defeat ISIS through counter-messaging and their capacity-building programs with neighboring states indirectly contribute to the Global Defeat-ISIS Coalition mission. Algeria is a member of the GCTF and co-chaired the GCTF's West Africa Region Working Group.

2019 Terrorist Incidents: Neither AQIM nor ISIS conducted any attacks in Algeria in 2019, although media reported that, on January 16, an unidentified terrorist group killed a lone shepherd in Tarek Ibn Ziad, a mountainous area about two-and-a-half hours southwest of Algiers. Several clashes, however, took place between terrorists and security forces during 
sweeping operations in which AQIM and ISIS primarily used IEDs and small arms. Algerian armed forces clashed with terrorists in 2019 in the following operations:

- On November 6, Algerian forces killed three members of a terrorist group in Tipaza, west of Algiers. Five Algerian soldiers were reported killed in the skirmish.

- On November 18, Algerian forces killed two alleged ISIS members during an operation along the southern border with Mali. ISIS media outlets characterized the same incident as an attack killing eight Algerian troops.

Legislation, Law Enforcement, and Border Security: Algeria has made no significant changes to its CT legal framework since 2018. The Algerian government maintained its strict "no concessions" policy with regard to individuals or groups holding its citizens hostage.

Algerian military forces and multiple law enforcement, intelligence, and security services addressed counterterrorism, counter-intelligence, investigations, border security, and crisis response. These included the various branches of the Joint Staff, the Algerian army, 140,000 members of the National Gendarmerie, and border guards under the Ministry of National Defense (MND); and about 210,000 national police, or General Directorate of National Security, under the Ministry of Interior. Public information announcements from the MND provided timely reporting on incidents during which MND forces captured or eliminated terrorists and seized equipment, arms, ammunition caches, and drugs.

Border security remained a top priority. Media reported on continued cooperation between Algeria and Tunisia including a joint Algerian-Tunisian terrestrial and aerial force military operation against ISIS strongholds in the border area, resulting in the destruction of terrorist hideouts and homemade bombs. The Government of Algeria closely monitored passenger manifests of inbound and outbound flights. Algeria also has a national API and PNR strategy and is setting up an API/PNR commission. As of this year, Algeria has a Passenger Information Unit operating under the General Directorate of Customs. Government officials made active use of INTERPOL databases at ports of entry.

Algerian law enforcement agencies participated in training and exchanges offered by the U.S. government and by third countries. Algerian participants attended numerous workshops conducted under the GCTF, the UN, and other multilateral organizations.

Countering the Financing of Terrorism: Algeria is a member of the MENAFATF. Its FIU, known as the Financial Intelligence Processing Unit, is a member of the Egmont Group. There were no significant updates in 2019.

Countering Violent Extremism: Algeria pursues a whole-of-government approach to CVE, including rehabilitation and reintegration programs for repentant terrorists. The regulation of mosques to ensure they are "de-politicized" and "de-ideologized" is a key aspect of the Algerian approach. Algeria acknowledges the crucial role of women and families in CVE efforts, and of its mourchidates, female Muslim clerics who work with young girls, mothers, and prisoners. The Algerian government monitors mosques for possible security-related offenses and prohibits the use of mosques as public meeting places outside of regular prayer hours. 
Government officials publicly affirm Algeria's Sunni Maliki tradition of Islam, which they believe provides a "moderate" religious vision for the country. The government periodically imposes restrictions on other variants of Islam for failure to abide by administrative procedures required of all religious institutions.

International and Regional Cooperation: Algeria continued to support CT efforts through regional and multilateral organizations. As co-chair of the GCTF's West Africa Region Capacity-Building Working Group, Algeria participated in joint working group meetings with other GCTF elements. Algeria has taken a leadership role in AFRIPOL, the Algiers-based AU mechanism for police cooperation, whose mandate is to enhance African police cooperation and prevent transnational crime and terrorism. In 2019, Algeria hosted the AFRIPOL general assembly and the first meeting of heads of national AFRIPOL liaison offices. Algeria also hosted the AU's annual CVE focal point representatives meeting at the Algiers-based African Center for Study and Research on Terrorism.

Algeria continued diplomatic engagement to promote regional peace and security. Algeria remains chair of the implementation committee for the peace accord in Mali and continued to support the UN political process in Libya. Algeria also participated in various Sahel-Saharan fora to discuss development and security policies and the evolution of regional terrorism. Regional tensions between Morocco and Algeria remained an impediment to bilateral and regional CT cooperation in 2019.

\section{BAHRAIN}

Overview: There were no successful terrorist attacks in Bahrain in 2019, but domestic security forces conducted numerous operations to preempt and disrupt attack planning. The Government of Bahrain (GOB) is a member of the Global Coalition to Defeat ISIS and supported U.S. government counterterrorism efforts. Political relations between the predominantly Sunni-led government and Shia-majority opposition remained tense, exacerbated by the July execution of two Bahraini Shia convicted on terrorism charges. According to press and NGO reports, confessions are usually obtained through torture, and mistreatment and abuse of Shia persons by security forces continues. GOB initiated numerous programs intended to improve community and security force relations. Bahrain experienced periodic low-level violence in predominantly Bahraini Shia villages, usually to mark notable dates of importance, such as the anniversary of the 2011 political unrest.

2019 Terrorist Incidents: There were no terrorist attacks reported in Bahrain in 2019.

Legislation, Law Enforcement, and Border Security: In May, the GOB ratified amendments to Bahrain's 2006 Anti-Terror Law that allows for penalties of up to five years in prison for encouraging or possessing materials that support "terrorist activities."

Throughout the year, Bahrain continued to conduct security operations targeting suspected militants. Individuals apprehended during security raids were tried in Bahraini courts, and some were convicted of involvement in terrorism-related activities. In April, a Bahraini court sentenced to prison 139 Bahrainis, of whom 69 received life sentences (25 years), on terrorism 
charges; the court also ordered the revocation of their citizenships. The GOB accused the individuals of forming an organization it referred to as "Bahraini Hizballah" with the intention of carrying out attacks in Bahrain. Also in April, King Hamad bin Isa Al Khalifa restored the citizenship of 551 prisoners, some of whom were convicted of terrorism. On October 31, the judiciary issued life sentences to five nationals for "forming a terrorist cell" affiliated with alAshtar Brigades.

In July, Bahrain executed two individuals who were found guilty in January 2018 of involvement in terrorist operations that led to the death of a Ministry of Interior police officer in 2017. The executions prompted demonstrations particularly in Bahraini Shia villages, and one 22-year-old protester died from what the GOB said was natural causes. Subsequent protests in response to the youth's death were non-violent.

Bahraini law enforcement agencies participated in training and technical assistance offered by the U.S. government.

Countering the Financing of Terrorism: Bahrain is a member of MENAFATF. Its FIU, known as the Financial Intelligence Directorate, is a member of the Egmont Group. Bahrain is also a member of the Defeat ISIS Coalition's CIFG and the Terrorist Financing Targeting Center (TFTC).

On August 28, the GOB convicted nine suspects of receiving and transferring funds to support terrorist activities; authorities handed down maximum jail terms of six years and imposed fines of up to $\$ 37,695$.

On December 2, in collaboration with other TFTC member states, Bahrain imposed one round of sanctions against individuals and entities affiliated with the Iranian regime's terror-support networks in the region.

As of December 2, Bahrain added "Hizballah of Bahrain, ISIS in Iraq and Syria, the 14 February Youth Coalition, al-Ashtar Brigades, People's Resistance Brigades, al-Mukhtar Brigades, Bahrain Freedom Movement" to its terror list.

Countering Violent Extremism: The GOB continued its efforts to adopt a national strategy in line with the UN Secretary-General's "Preventing Violent Extremism Plan of Action." Additionally, numerous officials from the GOB and local NGOs developed programming targeting youth and other vulnerable populations.

The GOB attempted outreach through initiatives such as the community police, which bridges the divide between the Bahraini Shia community and police force. In March, the Interior Minister launched the "National Plan to Promote the Spirit of Belonging," a program intended to foster a shared Bahraini identity. An executive committee was formed to oversee ministry activities under the initiative, also known as Bahrainuna (We are Bahrain). 
There is no overall strategic messaging campaign to counter terrorist narratives, although GOB leaders often speak publicly about tolerance and reducing sectarian rhetoric. GOB restrictions on freedom of religion, expression, assembly, and association may also increase the likelihood of radicalization.

A large number of Bahraini Shia youths serving prison sentences related to crimes committed during Bahrain's 2011 political unrest are expected to be released within the next several years. Prison conditions may increase the likelihood of radicalization.

International and Regional Cooperation: As of December 2019, members of the Bahrain Defense Force were deployed in Yemen as part of the Saudi-led coalition against the Iran-backed Houthi militants and al-Qai'da in the Arabian Peninsula. Bahrain is a member of the Gulf Cooperation Council, the Organization of Islamic Cooperation, and the Arab League. Bahrain continued to offer its support for countering Iran's malign activities in the region.

\section{EGYPT}

Overview: Nearly all terrorist attacks in Egypt took place in the Sinai Peninsula and largely targeted security forces, but terrorist attacks targeting civilians, tourists, and security personnel in mainland Egypt remained a concern. Though early 2019 witnessed a series of IED incidents in greater Cairo, those incidents became more infrequent as the year progressed. ISIS-Sinai Province (ISIS-SP) carried out the majority of the total attacks in 2019, though it claimed no attacks in mainland Egypt and no attacks against Western interests. ISIS-SP responded to ISIS's call to increase attacks to avenge the terrorist group's territorial defeat in Syria in March. ISISSP was the first affiliate to swear allegiance to the new self-proclaimed caliph in November. There were at least 151 IED-related attacks in Egypt in 2019, of which ISIS-SP conducted at least 137 in northern and central Sinai, along with near-weekly complex assaults on governmentfortified positions, demonstrating the terrorist group's freedom to maneuver during daytime hours and geographic expansion of attacks westward, toward the Suez Canal Zone, and southward. In addition, Harakat Sawa'd Misr (HASM) and al-Qa'ida allied groups such as Ansar al-Islam are believed to be behind the spate of anti-western attacks in mainland Egypt in 2019, and they also posed a continued threat.

While terrorist attacks primarily targeted Egyptian security personnel, civilians and foreigners were also targeted. Of note, terrorist groups carried out increased kidnappings and executions of individuals suspected of collaborating with the Egyptian government and military, particularly in April and June. Coptic Christians and other religious minorities continue to be targets for terrorist attacks.

As noted in the U.S. Department of State's Country Reports on Human Rights Practices and International Religious Freedom Report, NGOs continued to claim that authorities used counterterrorism and state-of-emergency laws and courts unjustly to prosecute journalists, activists, lawyers, political party members, university professors, and critics for exercising freedom of expression.

Egypt is a member of the Global Coalition to Defeat ISIS. 
2019 Terrorist Incidents: Overall terrorist attack methods throughout Egypt included small arms attacks, IEDs, VBIEDs, kidnappings, executions, complex assaults, ambushes, and targeted assassinations. Notable terrorist incidents in 2019 included:

- On January 23, HASM claimed responsibility for a VBIED attack targeting security forces in Giza, which killed or wounded 10 soldiers.

- On February 16, ISIS-SP attacked a government checkpoint near Al-Arish in North Sinai, killing 15 security personnel.

- On February 20, security forces detected and safely diffused an IED in Cairo planted by unidentified militants.

- On March 7, suspected terrorists opened fire on a security checkpoint on the Ring Road in Giza, resulting in one soldier wounded and three militants killed.

- On March 26, ISIS-SP claimed responsibility for an attack against aid workers in North Sinai that killed 12 civilians.

- On May 19, for the second year in a row, unidentified terrorists detonated an IED under a tour bus carrying foreigners near the Great Pyramids at Giza.

- On June 25, ISIS attacked a police assembly center and at least three checkpoints near Al-Arish in North Sinai, killing 10 people and wounding eight others.

- On July 16, ISIS-SP beheaded four individuals, whom the group claimed were informants for the Egyptian Armed Forces, near Bir al-Abd in North Sinai.

- On August 4, a VBIED detonated in front of the National Cancer Institute in Cairo. The Egyptian government blamed HASM, though the group denied responsibility.

Legislation, Law Enforcement, and Border Security: In March, the Egyptian Parliament's legislative committee approved new amendments to the 2015 Anti-Terrorism Law, increasing the punishment to 10 years in prison for those who promote "extremist" ideology as defined by Egyptian law. The punishment was increased to a minimum of 15 years if the promotion of "extremist" ideology was made at places of worship, public places, among members of the Armed Forces or the police, or in places allocated for these forces. Parliament is expected to pass these amendments, and President Sisi is then expected to ratify them in 2020.

In October, the Egyptian Parliament formed a new counterterrorism committee to revise national legislation and enable a more effective strategy against those who commit terrorist acts as defined by Egyptian law. This committee will propose amendments to existing legislation that gives law enforcement agencies additional powers to fight terrorism and accelerate trials of suspects charged with terrorist attacks. The committee will also make recommendations for religious and educational establishments, to include upgrading school curricula and removing content that might indirectly contribute to the "radicalization" of Egyptians.

Egypt's most significant physical border security concerns remained Libya, Sudan, and Gaza. At border crossings and airports, Egyptian authorities continued to check for the presence of security features in travel documents. They also conducted checks of some individuals and shared derogatory information across the Egyptian Border Guard. Egypt maintains a terrorist watchlist for Egyptian immigration officials at the ports of entry, with detailed information maintained by the security services. The United States assisted Egypt's CT efforts by providing 
training, equipment, and other assistance to its law enforcement security services, as well as to the Egyptian Ministry of Defense.

In July, British Airways and Lufthansa temporarily suspended flights to Egypt, citing unspecified security concerns, but resumed flights after one week and one day, respectively. In October, the United Kingdom lifted restrictions on flights to Sharm el-Sheikh for the first time since flights were banned in November 2015 following the downing of a Russian Metrojet airliner in an attack claimed by ISIS-SP.

Countering the Financing of Terrorism: Egypt is a member of MENAFATF. Its FIU, the Money Laundering and Terrorist Financing Combating Unit, is a member of the Egmont Group and the National Council of Payments. Egypt is also a member of the Defeat ISIS Coalition's CIFG. There were no significant updates in 2019.

Countering Violent Extremism: The government continued its ongoing CVE efforts in 2019. In January, the Ministry of Islamic Endowments (Awqaf) inaugurated an academy to train imams and preachers and brought together 130 ministers of endowments and muftis from around the world for a conference to counter "extremist narratives" and promote pluralism. Al-Azhar continued to publish statements promoting tolerance and in January introduced several new academic textbooks focusing on the relationship between Muslims and Christians and promoting equal rights between the two religions. In February, Pope Francis and Grand Imam Ahmed ElTayyeb signed a historic document pledging fraternity between the Vatican and Al-Azhar to work together to fight "extremism." Al-Azhar additionally cooperated with the Arab League to continue organizing conferences focused on countering terrorist radicalization and recruitment.

The Ministry of Awqaf additionally focused on bridging the divide between Muslims and Christians, bringing together representatives from both faiths to debate issues of mutual concern in an effort to address sectarian issues, particularly in Upper Egypt.

Dar al-Iftaa, an official body associated with Al-Azhar that issues religious edicts, focused its efforts on rejecting "extremist" ideology. In an effort to counter ISIS, which in the past has demolished several shrines, Dar al-Iftaa published a fatwa saying that praying in a mosque with a shrine annexed to it was commendable in Islam, despite other fatwas contrary to this position.

The Cairo Center for Conflict Resolution and Peacekeeping in Africa (CCCPA) continued training through its Preventing Radicalization and Extremism Leading to Terrorism (PRELT) program, which aims to prevent the proliferation of "extremist ideology." CCCPA trained 21 Arab women leaders in refuting "extremist interpretations" of religion and developing alternative religious narratives, and it hosted an advanced PRELT training for Sahel religious leaders.

The World Organization for Al-Azhar Graduates held a July workshop for Libyan imams and preachers with Azhari senior scholars on combating "extremism" and promoting moderate Islam. In October, a similar event was held on promoting tolerance. 
Despite measures taken by the Egyptian government - such as establishing parameters to identify individuals vulnerable to recruitment and offering training and religious guidance to inmates - concerns persisted that Egyptian prisons continue to be a fertile environment for terrorist recruitment and radicalization.

International and Regional Cooperation: Egypt continued to support CT efforts through regional and multilateral organizations, including through the GCTF. Egypt currently co-chairs the GCTF East Africa Working Group with the EU. As Chair of the Peace and Security Council of the AU, Egypt regularly prioritized CT issues including during their ASWAN Forum.

\section{IRAQ}

Overview: Iraqi Security Forces (ISF) remained in nominal control of territory liberated from ISIS. ISIS continued to present a serious threat to Iraqi stability, undertaking targeted assassinations of police and local political leaders and using IEDs and shooting attacks directed at both government and government-associated civilian targets, in support of a violent campaign to reestablish a caliphate. ISIS sought to reestablish support among populations in Ninewa, Kirkuk, Diyala, Salah ad Din, and Anbar provinces, especially in the areas of disputed control between the Kurdistan Regional Government (KRG) and the federal government, where the division of responsibility for local security is unclear. Although ISIS maintained the capability to conduct deadly terrorist attacks in Iraq, these attacks resulted in fewer casualties in 2019 than in previous years. Attacks by Iran-backed Shia militia groups on Iraqi bases hosting U.S. and Defeat-ISIS Coalition forces increased in 2019, killing and wounding American and Iraqi servicemembers. The Iran-backed, U.S.-designated KH continued to operate in Iraq and in some cases sought to enter local politics by backing provincial candidates. The Government of Iraq issued Executive Order 237 which required all Popular Mobilization Forces (PMF), including those backed by Iran, to operate as an indivisible part of the armed forces and be subject to the same regulations; however, many of these groups continued to defy central government command and control and engaged in violent and destabilizing activities in Iraq and neighboring Syria, including attacks on and abductions of civilian protesters. The Kurdistan Workers Party (commonly known as the PKK), a terrorist group headquartered in the mountains of northern Iraq, continued to conduct attacks in Turkey.

Iraq is a pivotal member of the Global Coalition to Defeat ISIS and a participant in all Coalition Working Groups (Foreign Terrorist Fighters, Counter-ISIS Finance Group, Stabilization, and Communications).

2019 Terrorist Incidents: According to the Federal Intelligence and Investigation Agency within Iraq's Ministry of Interior, acts of terrorism, violence, and armed conflict with ISIS killed more than 534 civilians and injured more than 1,121 in 2019 as of December 1 . This was a decrease from 2018, when roughly 900 civilians died and 1,600 were injured. ISIS continued to carry out suicide and hit-and-run attacks throughout the country with 844 attacks during the year. The most significant of these was a bus bombing in September that killed 12 Iraqis near the major pilgrimage site of Karbala. In addition, Iran-backed Shia militia groups are believed to be responsible for more than a dozen rocket or indirect fire attacks targeting U.S. or Coalition targets in Iraq in 2019, including the December 27 attack in which KH launched more than 30 
rockets at an Iraqi base hosting U.S. forces in Kirkuk, killing one American contractor and wounding several American and Iraqi service members. Other prominent terrorist attacks included:

- On January 11, a VBIED detonated in a market in al-Qa'im, on the Syrian border in western Anbar, killing two civilians and injuring 25 others.

- ISIS targeted truffle hunters mostly in Anbar province, kidnapping more than 44. On June 1, nine bodies were found west of the town of Rutba, some 300 kilometers west of Anbar's provincial capital Ramadi.

- On November 8, a car bomb exploded near a restaurant in Mosul, Ninewa governorate, killing 13 people and wounding 23 others.

- On November 16, an IED exploded in Baghdad's Tahrir Square where anti-government protesters gathered. There were no reported casualties.

- On November 29, ISIS attacked Kurdish security force (Kulajo Asayish) headquarters in Kifri district, Diyala governorate, killing three Asayish members, including the unit's director.

- On December 4, an ISIS tactical element comprising 10 to 15 members conducted an attack against the Ministry of Peshmerga's 3rd Regional Guard Brigade, killing three and wounding two others.

- On December 31, Iran-backed Shia militia groups, including KH, participated in an attack on the U.S. Embassy in Baghdad, which resulted in significant damage to embassy property. There were no embassy casualties and security personnel used less-than-lethal countermeasures to repulse intruders.

Legislation, Law Enforcement, and Border Security: Iraq made no significant changes to its counterterrorism legal and law enforcement framework in 2019.

Border security remained a critical capability gap, as the ISF has limited capability to fully secure Iraq's borders with Syria and Iran. While border security along the periphery of the Iraqi Kurdistan Region (IKR) is robust and administered by various security units under the Kurdish Minister of Interior, the border with Syria south of the IKR remained porous and vulnerable to ISIS and other terrorist networks, as well as to smuggling and other criminal enterprises. Iranbacked PMF units continued to maintain a presence at Iraq's major border crossings. The Iraqi government re-opened the Iraq-Syria border crossing in al-Qa'im under Border Police control, though various PMF units positioned themselves to the north and south of the main checkpoint.

Iraq and the United States partnered to close a gap in border security through broader deployment of and upgrades to the U.S.-provided PISCES. The Ministry of Interior shared biometric information upon request on known and suspected terrorists and shared exemplars of its identity documents with the United States, INTERPOL, and other international partners, though there remained no agreement or arrangement in place that would support the implementation of an intended U.S. program to facilitate biometric information-sharing on both terrorist and criminal suspects. In the Disputed Internal Boundaries, ISIS continues to exploit the security vacuum between Iraqi Security Forces and Peshmerga Forces. Recent attacks in the northern Diyala and activities along Qarachogh Mountain indicate ISIS presence. Counterterrorism efforts in the Disputed Internal Boundaries areas have been hampered by the 
lack of coordination between Peshmerga and ISF, mainly due to the relationship between the KRG and the Government of Iraq. Additionally, Iraq has taken preliminary steps to partner with UNITAD in the collection of digital, documentary, testimonial, and forensic evidence to support the prosecution of ISIS members for their atrocity crimes committed in Iraq.

Countering the Financing of Terrorism: Iraq is a member of MENAFATF. Iraq is also a member of the Defeat-ISIS Coalition's CIFG. In 2019, the IKR began setting up its own AML/CFT Committee that will coordinate across relevant KRG ministries and work with the IKR's Terrorism Finance Unit.

The Government of Iraq - including the Central Bank of Iraq, law enforcement, security forces, and the judiciary - continued to dismantle ISIS's financial networks and safeguard Iraq's financial institutions from exploitation by ISIS. Efforts include:

- Iraq cooperates closely with the U.S. government on multiple U.S. designations under U.S. CT authorities.

- Iraqi and Kurdish agencies coordinating actions with the U.S. Departments of Defense and the Treasury against Afaq Dubai to disrupt and curtail ISIS's logistical infrastructure and its ability to generate, store, and use funds for recruiting and paying its fighters and for its operations.

- Iraq shared a list of banned exchange houses and money transfer companies with regional regulators and tasking judicial action against more than a dozen individuals and companies suspected of illicit financial activity. These actions ranged from business closures to arrests of suspects.

Countering Violent Extremism: Iraq remained active in its strategic messaging to discredit ISIS, including through its membership in the Global Coalition to Defeat ISIS Communications Working Group, and engaged with U.S. military and civilian counterparts to develop a wide range of capabilities to build national cohesion and combat terrorist ideology. The Government of Iraq and the Global Coalition to Defeat ISIS also implemented stabilization, reconciliation, and accountability programs to strengthen locals' ability to counter terrorist radicalization and recruitment.

Many Iraqi ISIS fighters remained in Iraqi custody, along with ISIS-affiliated foreign women and children. Iraq acknowledged that the return and reintegration of family members of suspected ISIS supporters, as well as the provision of fair and equal justice, are important to prevent future terrorist radicalization and violence. However, more than 1.4 million Iraqis remain displaced within Iraq, and more than 30,000 - mainly women and children - reside in the al-Hawl IDP camp in Syria. Iraq publicly stated it has no intention of housing Iraqi ISIS fighters with the general prison populations in Iraqi prisons. The lack of separate, secure detention facilities within Iraq delayed Iraqi efforts to repatriate additional Iraqi fighters detained abroad.

International and Regional Cooperation: Iraq continued to work with multilateral and regional organizations - including the UN, the Global Coalition to Defeat ISIS, NATO, the Organization of Islamic Cooperation, INTERPOL, and the Arab League - to support CT efforts. 


\section{ISRAEL, WEST BANK, AND GAZA}

$\underline{\text { Israel }}$

Overview: Israel was a committed counterterrorism partner in 2019, closely coordinating with the United States on a range of counterterrorism initiatives. Israel and the United States held numerous interagency counterterrorism dialogues to discuss the broad range of threats in the Middle East and to determine areas of collaboration to address these challenges. This included the annual meeting of the U.S.-Israel Joint Counterterrorism Group, which was launched in the early 1990s and is our longest-standing strategic counterterrorism dialogue.

Israel faced threats from the north from Hizballah and along the northeastern frontier from Hizballah and other Iran-backed groups, including about 150,000 rockets aimed at Israel. Israeli officials expressed concern that Iran was supplying Hizballah with advanced weapons systems and technologies, as well as assisting the group in creating infrastructure that would permit it to indigenously produce rockets, missiles, and drones to threaten Israel from Lebanon, Syria, Iraq, or Yemen.

To the south, Israel faced threats from terrorist organizations including Hamas, Palestine Islamic Jihad (PIJ), and ISIS-Sinai. Rocket attacks originating from Gaza resulted in four deaths and dozens of injuries in 2019.

2019 Terrorist Incidents: Israel experienced numerous terrorist attacks in 2019 involving weapons ranging from rockets and mortars to small arms and knives. The following is a partial list of terrorist incidents that occurred in 2019:

- On February 7, an assailant violently assaulted and stabbed to death 19-year-old Ori Ansbacher in the EinYael forest near Jerusalem. Police arrested Arafat Irfiya, a 29-yearold Palestinian man from Hebron and reported he admitted the attack was "nationalistically motivated."

- Hamas and other terrorist groups including PIJ launched more than 1,000 rockets and mortar shells from Gaza toward Israel during the year, some of which landed in civilian areas. For details, see "West Bank and Gaza" section below.

Legislation, Law Enforcement, and Border Security: Israel has a robust legal framework to combat terrorism and promote international legal assistance in the investigation and prosecution of terrorists. In December, the defense minister signed the first executive order placing economic restrictions on assets of an individual connected to terrorism: Mohammad Jamil, a Hamas activist living in the United Kingdom.

Israeli security forces took numerous significant law enforcement actions against suspected terrorists and terrorist groups. The following examples represent some of the law enforcement actions taken in 2019: 
- On October 28, Border Police officers arrested two ISIS members who planned a terrorist attack either in Jerusalem or against an Israel Defense Forces (IDF) army base in the Jordan Valley with the intention to kill as many civilians and military personnel as possible.

- In June, Shin Bet (Israel Security Agency) arrested an Israeli Bedouin supporter of Hamas, who planned to bomb a hotel in southern Ashdod.

- On August 6, Israeli security forces arrested three members of a Hamas bomb team, thwarting a major plot targeting Jerusalem.

Countering the Financing of Terrorism: Israel remains a full member of the FATF. Israel's FIU, the Israeli Money Laundering and Terror Finance Prohibition Authority, is a member of the Egmont Group.

In accordance with the Israeli Deduction Law, the Ministry of Defense announced in February 2019 that it would withhold \$138 million (\$12 million a month) from monthly tax revenue Israel collects and transfers to the Palestinian Authority (PA), which is the amount Israel determined the PA paid in 2018 to Palestinians connected to terrorism, including Palestinian terrorists in Israeli prison and released Palestinian terrorists. The PA responded to Israel's withholding by refusing to accept any of its remaining tax revenues from Israel, representing about 65 percent of the PA's budget. As the PA's fiscal situation worsened, the PA eventually agreed in October 2019 to accept its remaining tax revenues.

In December 2019, Israel announced that it would withhold an additional \$43 million from PA revenues for payments the PA provided during 2018 to families of Palestinians who were wounded or died while committing terrorist acts or in connection with terrorism. Israel also seized funds the PA paid to eight Israeli Arabs convicted of terrorism and their families. The PA argues these payments are social payments for families who have lost their primary breadwinner. The United States and Israel argue the payments incentivize and reward terrorism, with higher monthly payments for lengthier prison sentences tied to more severe crimes.

Countering Violent Extremism: The Ministry of Public Security supported and funded Israel's flagship City Without Violence initiative. One hundred fifty-one municipalities implemented education and social welfare projects to counter violence, crime, and terrorism. The program emphasized partnerships with the Israel National Police, with the goal of reducing violence and increasing citizen-police communication.

The president of Israel's initiative, Israeli Hope, in cooperation with government ministries, established a sustainable partnership across different segments of Israeli society, focusing on projects ranging from education to employment to sports. The sports initiative, with the cooperation of the Ministry of Culture and Sports, implemented programs aimed at countering racism and reducing violence in collaboration with professional soccer clubs and players.

International and Regional Cooperation: According to media reports, Israeli intelligence helped Denmark foil a series of terror attacks, resulting in 22 arrests in December. Other media reports stated that Israeli intelligence officials helped foil more than 50 terrorist attacks planned worldwide by Iran and its proxies, as well as by ISIS, during the 2017-2019 period. 


\section{The West Bank and Gaza}

Overview: The Palestinian Authority continued its counterterrorism and law enforcement efforts in the West Bank, where Hamas, PIJ, and the Popular Front for the Liberation of Palestine (PFLP) remained active. PA officials continued to make inconsistent statements about a commitment to non-violence. The PA security forces constrained the ability of terrorist organizations and individuals to conduct attacks, in part by arrests targeting those planning attacks against Israelis. Per Oslo-era agreements, the PA exercised varying degrees of authority over the West Bank owing to the presence of IDF in certain areas, as well as frequent Israeli entry into PA-controlled areas for counterterrorism operations. The IDF and Shin Bet also arrested individuals and members of terrorist organizations operating in the West Bank.

The United States continued to coordinate with PA security forces in counterterrorism efforts. U.S. advisory support assisted the PA as it continued to develop professional security forces capable of some, but not all, counterterrorism functions.

The number of Palestinian terrorist attacks against Israelis in the West Bank in 2019 was in line with rates in recent years and lower than rates during the heightened period of violence from October 2015 to April 2016. Methods employed included stabbings, shootings, bombings, and vehicular attacks.

Some Israelis committed retaliatory "price tag" attacks involving property crimes and other violent acts against Palestinians in the West Bank in 2019. For example, in November 2019, "price tag" attacks were reported in multiple Palestinian villages in which vehicles were vandalized and olive tree groves were destroyed.

Hamas maintained control of Gaza in 2019. Several militant groups, including Hamas and PIJ, launched rocket attacks against Israel from Gaza, including significant attacks against Israel in May. PIJ led other large attacks against Israel in November and members of PIJ committed suicide attacks against Hamas civil police. During weekly protests at the Israel-Gaza security fence with Israel, Palestinians threw Molotov cocktails and IEDs, and they launched incendiary balloons and devices towards Israel, damaging farms and nature preserves. According to the head of Israel's Eshkol regional council, the total damage in 2019 was estimated at $\$ 3.46$ million. Hamas and PIJ terror tunneling activities continued.

2019 Terrorist Incidents: The following are representative examples of some of the terrorist incidents:

- Hamas and other terrorist groups including PIJ launched more than 1,000 rockets and mortar shells from Gaza toward Israel during the year, some of which landed in civilian areas. The IDF confirmed that the Iron Dome, Israel's air defense system, intercepted most of these projectiles.

- In March, a rocket from Gaza hit a house in Kfar Saba, injuring seven people including grandparents and three children.

- Also in March, at the Ariel junction in the West Bank, a Palestinian stabbed an IDF soldier, grabbed his weapon, and shot him. As he escaped, the assailant shot and killed a 
civilian and wounded another soldier before briefly escaping and ultimately being killed in a shootout with the IDF.

- In May, during a barrage of 690 rockets and mortars from Gaza, six Israelis were killed. In July, a Palestinian man crashed his car into a group of five IDF soldiers and wounded them near the Hizma check point.

- In August, Palestinians detonated a homemade bomb in a public area near Ramallah, killing an Israeli teenager and wounding her father and brother. According to Shin Bet, the suspects were members of the PFLP.

- Also in August, two suicide bombers detonated themselves near police checkpoints in Gaza City, killing three police officers and wounding three other Palestinians.

- Also in August, two Palestinian men were arrested for stabbing to death an 18-year-old Yeshiva student near Gush Etzion Junction.

- During November 12-13, 562 rockets and mortars were fired from Gaza into Israel, forcing schools to close and civilians to take shelter in affected areas.

Legislation, Law Enforcement, and Border Security: The PA lacked comprehensive legislation specifically tailored to counterterrorism, although existing Palestinian laws criminalize actions that constitute terrorist acts. Presidential decrees prohibit incitement to violence, illegal associations, providing financial support to terrorist groups, and acts that run counter to Palestine Liberation Organization (PLO) agreements with other states (an indirect reference to the Oslo Accords with Israel). The Palestinian legislature, the Palestinian Legislative Council, was dissolved in December 2018 and is therefore unable to pass new laws. Governance is managed by presidential decree. NGOs claimed that at times the PA made arbitrary arrests based on political acts and affiliation, including criticism of the PA online.

The Preventive Security Organization is the key PA institution that works to prevent West Bank terrorist attacks and investigates security-related criminal conduct. In practice, the General Intelligence Organization also plays a critical role in this effort, as does, to a lesser extent, the Military Intelligence Organization.

Per previous agreements, Israel retained control of border security across the West Bank and general security throughout Area $\mathrm{C}$, which encompasses a majority of the West Bank.

Countering the Financing of Terrorism: The PA is a member of MENAFATF, a Financial Action Task Force-style regional body, and will next be reviewed in 2020. The Palestinian Financial Follow-Up Unit (FFU) is the PA's FIU. Banks file suspicious transaction reports (STRs) and currency transaction reports electronically through the FFU computer system. In 2019, banks, law enforcement agencies, and other entities filed approximately 160 STRs (year to date, December 11, 2019) compared with 124 in 2018.

In 2019, the Palestinian Monetary Authority launched a new banking system, titled Know Your Customer, designed to help keep track of the sources and recipients of financial transactions to facilitate transparency, ensure customs duty collection, and comply with anti-money laundering laws. 
Countering Violent Extremism: Official PA media, TV, and social media accounts affiliated with the ruling political movement Fatah have featured content praising or condoning acts of terrorism, and Palestinian leaders did not consistently publicly condemn individual terrorist attacks. President Mahmoud Abbas has stated in the past a commitment to non-violence, a twostate solution, and previous PLO commitments, but he has also made inconsistent statements that appear to contradict and undermine his prior commitments. Abbas said on Palestinian media on March 24, "We want to achieve our right and our state peacefully...We will not choose a path other than negotiations to achieve our right." But according to translation by MEMRI, Abbas said on August 10, "So we say to them: "Every stone you [used] to build on our land and every house you have built on our land is bound to be destroyed, Allah willing...Jerusalem is ours whether they like it or not... We shall enter Jerusalem - millions of fighters! We shall enter it! All of us, the entire Palestinian people, the entire Arab nation, the Islamic nation, and the Christian nation... They shall all enter Jerusalem...",

International and Regional Cooperation: PA justice, security leaders, and PA security force personnel continued to participate in regional conferences and meetings to combat terrorism.

\section{JORDAN}

Overview: Jordan remained a committed partner on CT in 2019. As a regional leader in the Global Coalition to Defeat ISIS, Jordan played an important role in Coalition successes in degrading the terrorist group. Jordan continued to face a persistent threat of terrorist activity both domestically and along its borders, owing in part to its proximity to regional conflicts in Iraq and Syria and the state's official rejection of Salafi-Jihadi interpretations of Islam. Terrorist entities continue to express interest in attacking both "hard" and "soft" targets, such as highprofile public events, hotels, tourist locations, and Jordanian security services. The most notable terrorist incident in 2019 was the November 6 attack targeting foreign tourists in Jerash. Jordanian security forces thwarted several plots and apprehended numerous terrorists; however, coordination among Jordan's security services for terrorism response capabilities and prevention remains a challenge, but it continues to improve.

Border security remains an overarching priority for the Jordanian government, given fears that violence from the conflict in neighboring Syria will spill over into its territory. There were many Jordanian nationals among FTFs in Iraq and Syria, and the threat of domestic radicalization, especially online, remains. Returning FTFs are an ongoing concern for Jordan's security services. As a member of the GCTF, Jordan continued to be a committed partner on FTF issues in 2019 as co-chair with the United States of the GCTF FTF Working Group.

2019 Terrorist Incidents: On November 6, a 22-year old Palestinian from a nearby refugee camp stabbed eight people, including four foreign tourists, in Jerash, one of Jordan's most popular tourism sites.

Legislation, Law Enforcement, and Border Security: Jordan made no significant changes to its counterterrorism legal framework in 2019. 
The General Intelligence Directorate (GID) is the primary government agency responsible for counterterrorism. It operates with support from various elements within the Jordan Armed Forces, the Public Security Directorate, and the Gendarmerie. The Jordanian government continued to implement measures and conduct joint exercises to improve interagency coordination among security agencies during responses to terrorism-related events. Enhanced overt security measures are in place across Jordan, most visibly at hotels and shopping malls.

Jordanian security services disrupted a number of terrorist plots in various stages of operational planning. While successful interdictions showcase the government's efforts, they come in response to attempts to conduct terrorist operations in Jordan from a variety of terrorist groups or individuals with terrorist aspirations, including those inspired by ISIS and al-Qa'ida. On November 12, the Jordanian newspaper Al-Rai reported that the GID thwarted terrorist operations of two suspects who planned to target employees of the U.S. and Israeli embassies, as well as U.S. soldiers at a military base in the Jafr region. The GID reportedly arrested the two suspects in July, and their trial in the State Security Court (SSC) began in early November. The SSC sentenced one of the suspects to eight years in prison for threatening to attack the Israeli Embassy in Amman. The SSC also convicted several detainees on terrorism charges. Sentences ranged from three years to life in prison with hard labor.

In 2019, Jordan did not extradite Ahlam Aref Ahmad Al-Tamimi, a Jordanian national in her mid-30s, who has been charged in the United States with conspiring to use a weapon of mass destruction against U.S. nationals outside the United States resulting in death. The charge is related to her participation in the August 9, 2001, suicide bomb attack at a pizzeria in Jerusalem that killed 15 people, including two U.S. nationals. Four other U.S. nationals were among the approximately 122 others injured in the attack. Following publication of the 2018 Country Reports on Terrorism, Foreign Minister Ayman al-Safadi confirmed that U.S. authorities asked Jordan to extradite Tamimi, and he expressed the view that Jordan's constitution does not allow the extradition of a Jordanian citizen to a third country. The United States regards the extradition treaty with Jordan as valid and in force.

Jordan continued to reinforce its border defenses and surveillance capabilities in response to terrorist and criminal threats emanating from its 230-mile border with Syria and 112-mile border with Iraq.

Countering the Financing of Terrorism: Jordan is a member of MENAFATF. Its FIU, known as the Anti-Money Laundering and Counter Terrorist Financing Unit, is a member of the Egmont Group. Jordan is also a member of the Defeat-ISIS Coalition's CIFG. MENAFATF completed its mutual evaluation of Jordan in 2019; while not published before the end of 2019, the report contained several recommendations to enhance its AML/CFT regime.

Countering Violent Extremism: Jordan is implementing a national strategy on preventing violent extremism coordinated by an office within the Prime Ministry. Priority areas for engagement include countering terrorist ideology, building social cohesion among civil society, and assisting law enforcement. Officials regularly engage experts on topics such as the role of women and girls in terrorism prevention, and the monitoring and evaluation of local conditions conducive to terrorism. Civil society organizations have undertaken work across the country to 
address causes of terrorism and offer positive alternatives to youth through activities that build critical thinking skills, encourage civic participation, increase awareness of online safety, and address the needs of returning terrorist fighters and their families. Irbid, Karak, and Zarqa are members of the SCN and worked to develop capacity in local communities to prevent violence and build community cohesion.

Jordan, in partnership with the United States, held the first Aqaba Process Tech Meeting to counter terrorism online in February 2019 in Napa, California, which included governments, technology companies, international organizations, civil society, and academics. Jordan held a follow-up Aqaba Process meeting in Amman in June that likewise focused on countering terrorist use of the internet. In September, Jordan co-sponsored with New Zealand and France at the United Nations the high-level "Leaders Dialogue: Strategic Responses to Terrorist and Violent Extremist Narratives."

International and Regional Cooperation: Jordan is a major non-NATO ally and founding member of the GCTF. It is a member of the United Nations, the Arab League, the Organization for Islamic Cooperation, the Global Initiative to Combat Nuclear Terrorism, and the Proliferation Security Initiative. Jordan also participates in the UN's Group of Friends of Preventing Violent Extremism.

\section{KUWAIT}

Overview: During 2019, the Government of Kuwait participated in or conducted a significant number of training programs to build CT capacity and to counter terrorism financing. Kuwait is a regional leader in the Global Coalition to Defeat ISIS, part of the Defeat-ISIS Coalition Small Group, and co-leads (with Turkey and the Netherlands) the Coalition's Foreign Terrorist Fighters Working Group.

2019 Terrorist Incidents: There were no terrorist incidents reported in Kuwait in 2019.

Legislation, Law Enforcement, and Border Security: Throughout 2019, Kuwaiti government officials participated in several CT capacity-building workshops. Several of these were supported by the U.S. Department of State and implemented through the U.S. Department of Justice Overseas Prosecutorial Development Assistance and Training program. In February, the Kuwaiti Public Prosecutor's office participated in a workshop on Best Practices in Cyber Investigations and Prosecutions. In March, the Ministry of Interior and the Kuwait State Security trained on FTF-related investigations. In April, Kuwait hosted the GCC Regional Cyber Investigations Conference with attendees from 26 entities across the Gulf and several domestic Kuwaiti entities, many focused on CFT. In October, the FIU and the National Committee for Combatting Money Laundering and Countering the Financing of Terrorism participated in a seminar on money laundering and countering the funding of terrorism. Kuwait also concentrated on law enforcement and judicial capacity building across a broad spectrum of government agencies.

In July, the Kuwait state news agency reported that the Ministry of Interior had deported eight Egyptian citizens who were wanted in Egypt for terrorism-related convictions. 
Countering the Financing of Terrorism: Kuwait is a member of MENAFATF. Its FIU, known as the Kuwaiti Financial Intelligence Unit, is a member of the Egmont Group. Kuwait is also a member of the Defeat-ISIS Coalition's CIFG and the TFTC.

In collaboration with other TFTC member states, in 2019 Kuwait imposed one round of sanctions against individuals and entities affiliated with the Iranian regime's terror-support networks in the region.

Countering Violent Extremism: Kuwait's Ministry of Education continued to implement a program to fight what it viewed as extremist ideologies at public schools through teachertraining and student-counseling programs. As part of the government's National Plan to Reinforce Moderation, the Ministry of Information runs a television channel with programming aimed at audiences believed to be at higher risk of radicalization. The Kuwait Moderation Center, which operates under the supervision of the Ministry of Religious Endowments, sponsored a variety of programs designed to promote religious tolerance, including establishing working groups to reduce sectarian conflict, holding symposia on protecting the rights of nonMuslims in a Muslim society, and a program in the school system to promote diversity and tolerance and combat sectarianism. The Moderation Center continued a program to enable social salon (diwaniya) hosts to invite religious scholars to join in discussions with attendees and counter the potential presence of radicalizing influences. The center also sponsored radio programs to promote tolerance among youth. In December, the Ministry of Foreign Affairs sponsored a workshop titled "The Concept of Extremism and its Reflection on Society." More effective measures are needed to prevent charitable donations being routed to regional terrorist groups or support for educational and religious advocacy efforts that encourage discrimination and violence. Kuwait is looking to better monitor charitable donations that might be used to support terrorist elements.

International and Regional Cooperation: During 2019, Kuwait served as a non-permanent member of the UN Security Council for the second year of its two-year term. Kuwait remained an active member of the Global Coalition to Defeat ISIS Small Group, participating in a number of ministerial-level meetings throughout the year. Kuwait has also long been an active member of the Arab League and the Organization of Islamic Cooperation. As a member of the GCC, Kuwait has played a leading role in the effort to mediate the dispute between Qatar and other GCC members.

\section{LEBANON}

Overview: Lebanon remains a committed partner in the Global Coalition to Defeat ISIS.

Terrorist groups operating in Lebanon included Hizballah, ISIS, Hamas, and the Abdullah Azzam Brigades. Of these, the Lebanon-based and Iran-backed terrorist group Hizballah remained the most capable. In August 2019, Israel publicly released information about Hizballah's efforts to produce precision-guided missiles (PGMs) within Lebanon. Hizballah announced that the group possessed enough PGMs for a confrontation with Israel but denied that it was developing PGM factories in Lebanon. Between December 2018 and January 2019, Israel 
uncovered and destroyed multiple tunnels dug by Hizballah under the border into Israel that could have been used for terrorist attacks.

Despite the Lebanese government's official policy of disassociation from regional conflicts, Hizballah continued its military role in Iraq, Syria, and Yemen, in collaboration with the Iranian regime. Separately, Lebanon's 12 Palestinian refugee camps remained largely outside the control of Lebanese security forces and posed a security threat because of the potential for militant recruitment and terrorist infiltration. In addition, several individuals on the FBI's most wanted list or listed by the State or Treasury Departments as Specially Designated Global Terrorists reportedly remained in Lebanon.

\section{Terrorist Incidents:}

- On June 3, Abdel Rahman Mabsout, a lone Lebanese gunman associated with ISIS, attacked a police patrol in Tripoli and killed two Internal Security Forces (ISF) officers and two Lebanese Armed Forces (LAF) soldiers before killing himself after being cornered by security forces. The attacker was previously arrested in 2016 for fighting for ISIS in Syria and imprisoned in Lebanon but was released in late 2017.

- On September 1, Hizballah launched three guided antitank missiles across the border into Israel at an IDF vehicle. The missiles did not cause any casualties.

- Hizballah continued to plan attacks around the world, as detailed in other sections of this report.

Legislation, Law Enforcement, and Border Security: Lebanon does not have a comprehensive counterterrorism law, but several articles of Lebanon's criminal code are effectively used to prosecute acts of terrorism. No new laws related to terrorism were passed in 2019. The LAF, ISF, the Directorate of General Security (DGS), and the General Directorate of State Security were the primary government agencies responsible for counterterrorism. Although cooperation among the services was inconsistent, they took steps to improve information sharing and were receptive to additional capacity building and reforms. Structural limitations in the justice system remained a barrier for conducting trials for terrorism cases in a timely manner.

The LAF held primary responsibility for securing Lebanon's land and maritime borders, while DGS and Customs were responsible for official points of entry. The LAF improved its ability to control Lebanon's land border with Syria through the Land Border Security Project funded by the United States, the UK, and Canada. This project resulted in greater control of the border and the arrest of ISIS members entering Lebanon from Syria. In February, the LAF arrested a Palestinian affiliated with the al-Nusrah Front for his role in fighting taking place inside the Ein el-Hilweh Refugee Camp.

Lebanon collected biographic data for travelers at the Beirut International Airport, as well as API and PNR data for commercial flights. The United States worked with Lebanon to develop a central repository to process and share biometric data among Lebanese services. In 2019, Lebanese security services collaborated with the United States on numerous instances to foil terrorist plots and investigate and apprehend individuals involved in terrorism. 
The presence of Hizballah in the Lebanese government was an impediment to effective host government action against terrorist incidents. For instance, the government took no action to hold Hizballah accountable for its rocket attack on Israel in September or the cross-border tunnels, and prevented the UN Interim Force in Lebanon from fully investigating these incidents by failing to provide access to the areas where these incidents occurred. In international fora, Lebanon argued that acts taken against what it characterized as "foreign occupation" are not terrorism, in an attempt to justify Hizballah's violence against Israel.

Countering the Financing of Terrorism: Lebanon is a member of MENAFATF. Its FIU, known as the Special Investigation Commission (SIC), is a member of the Egmont Group. Lebanon is also a member of the Defeat-ISIS Coalition's CIFG.

In 2019, the SIC took actions to comply with new U.S. sanctions against a number of Hizballah members and financers, including the sanctioning of Jammal Trust Bank for providing financial services to Hizballah. Lebanon also designated several individuals and entities on its national terrorism-financing list established pursuant to UNSCR 1373/2001 and proposed several designations to the UNSCR 1267/2253 Sanctions Committee. Lebanese authorities were still compiling specific statistics on such actions at year's end.

During the first nine months of the year, the SIC received 12 terrorism and terrorism-financing cases from local sources, out of which six cases were referred to the general prosecutor. The SIC reported that numerous terrorism and terrorism-financing prosecutions were carried out by judicial authorities in Lebanon, several of which led to convictions.

On August 29, Lebanon acceded to the International Convention for the Suppression of the Financing of Terrorism. However, it submitted a reservation concerning the definition of terrorism to endorse the definition from the Arab Convention for the Suppression of Terrorism of 1984, which excludes any acts taken against what is characterized as "foreign occupation."

Countering Violent Extremism: The National Preventing Violent Extremism Coordination Unit organized nine workshops on PVE in 2019. Local and international donor efforts included participation in the $\mathrm{SCN}$, as well as prevention programs in prisons.

International and Regional Cooperation: Lebanon supported CT efforts in regional organizations and participated in counterterrorism finance programs, such as MENAFATF. Lebanon offered training to regional peers in international standards to combat terrorist financing.

\section{LIBYA}

Overview: The ongoing conflict involving the Government of National Accord (GNA) and Libyan National Army (LNA)-aligned forces, as well as other nonstate actors, prevented Libyan authorities from dedicating sufficient resources to the fight against terrorist groups. However, both GNA- and LNA-aligned forces conducted CT operations during the year, arresting or killing dozens of ISIS or AQIM fighters. U.S. strikes on ISIS-Libya targets further degraded this 
group. The GNA continued to work with the United States to counter the spread of terrorist groups such as ISIS-Libya and AQIM, albeit to a more limited degree following the departure of U.S. forces from Libya in April. The GNA's effectiveness was constrained both by the lack of control it exerted over national forces and by its diminished geographic reach.

Since the 2016 expulsion of ISIS from Sirte, the group has lacked a concentrated, physical presence in Libya, instead spreading into smaller groups with a presence in both urban environments and the sparsely populated desert districts of Jufra, Sebha, and Murzuq. In southern Libya, where terrorist groups operated most freely, forces aligned with the LNA conducted operations against AQIM and ISIS. All acknowledged terrorist attacks by ISIS in 2019 were conducted against LNA forces or against civilian targets in areas under LNA control. The LNA undertook CT efforts in areas under its control.

In coordination with the GNA authorities in Tripoli, the United States conducted four precision airstrikes on ISIS in southern Libya in September 2019, killing 43 ISIS fighters and displacing remaining elements. The GNA has also cooperated with the United States on the investigation of suspected terrorists. Libya is a member of the Global Coalition to Defeat ISIS.

\section{Terrorist Incidents:}

- On April 9, ISIS militants killed two people in the town of al-Fuqaha in Jufra province (central Libya). One of the victims was the head of the municipal council. The group also kidnapped an LNA security official and burned several houses in the town. Former ISIS head Abu Bakr Al-Baghdadi later praised the attack in a video.

- On May 4, ISIS fighters carried out an assault against LNA forces at the Jabril Baba camp near the southern Libyan city of Sebha, killing at least nine LNA soldiers from the 160th Brigade, one of whom was beheaded. ISIS later claimed to have released inmates detained in the training camp's detention facility.

- On May 9, ISIS conducted an attack on the town of Ghadduwa (45 miles south of Sebha), killing three people, including former Libyan diplomat Ali al-Kaboush. ISIS also kidnapped one individual and issued a statement claiming responsibility for burning down 14 houses and local LNA military facilities.

- On May 18, ISIS fighters conducted a small-arms attack at a checkpoint on the road from Zilla to Waddan near a facility operated by a subsidiary of the Libyan National Oil Corporation, killing three LNA soldiers and briefly kidnapping four others. One of the ISIS fighters reportedly detonated a person-borne improvised explosive device to prevent capture.

- On July 11, three explosive devices were detonated at the Huwari Cemetery in Benghazi during the funeral of Khalifa Mismari, a former Libyan Special Forces commander. Several high-ranking LNA officers were present at the scene of the attack. No group has claimed responsibility for the attack, which killed four and wounded 33.

- On August 10, unknown attackers detonated a car bomb in front of a shopping mall near the Commerce and Investment Bank in the Hawari neighborhood of Benghazi targeting a UN Support Mission in Libya (UNSMIL) convoy. The attackers killed three UNSMIL guards and wounded scores of bystanders, including children. 
Legislation, Law Enforcement, and Border Security: Libya did not pass or implement any CT legislation in 2019. Libya lacks a comprehensive CT law, although the Libyan penal code criminalizes offenses that may threaten national security, including terrorism, the promotion of terrorist acts, and the handling of money in support of such acts. Libya has ratified the Africa Union's Convention on the Prevention and Combating of Terrorism, which requires states to criminalize terrorist acts under their national laws. The GNA has continued to support and seek international cooperation to combat ISIS.

A number of state and nonstate organizations, both outside and under official GNA authority, claimed CT responsibilities. GNA-aligned groups with the greatest CT capacity included the Misratan Joint Security Operations Room (MJSOR) and the Tripoli-based Special Deterrence Force (aka "Rada Force"), a Salafist militia nominally integrated into the GNA Ministry of Interior. MJSOR, Rada Force, and the GNA MOI conducted more than 20 arrest operations against terrorists who were current or former members of ISIS, AQIM, and other AQIMaffiliated groups in 2019, detaining more than 31 terrorist suspects. The LNA Western, Eastern, and Southern CT Operations Rooms conducted more than 25 operations during which it arrested at least 57 and killed at least 44 individuals connected with these same terrorist groups. Because of the limited geographic reach of the internationally recognized GNA, the GNA's ability to deter or reduce terrorist activities was limited to areas under its control. Libyan law enforcement personnel lacked clear mandates and the capacity to detect, deter, respond to, or investigate terrorist incidents due to continued political and security force fragmentation.

The Libyan government, through its National Team for Border Security and Management, continued work in 2019 to develop a comprehensive border management strategy. Although approval of a national strategy will be an important step, Libya continues to struggle to secure the country's thousands of miles of land, air, and maritime borders. The U.S. Department of State provided training and other technical assistance to Libyan airport officials, border guards, customs agents, and police and intelligence forces in securing airports against the threat of terrorism, which included preventive security measures consisting of access control, passenger and cabin baggage screening, hold baggage screening, and air and mail cargo handling.

Despite the arrests of dozens of new terrorist suspects and the referral of some suspects to the public prosecutor, there were no reported terrorism-related prosecutions in 2019. In many parts of Libya, armed groups, rather than state institutions, provide security and law enforcement functions, including detention of terrorist elements. National police and security forces are fragmented, are inadequately trained and equipped, and lack clear reporting chains and coordination mechanisms. Libya's military forces are similarly weak and fragmented. Nonstate armed groups often overshadow formal security structures.

The following are two examples of operations and arrests by state and nonstate forces in 2019:

- On November 29, the GNA Ministry of Interior arrested Emad Faraj Mansour al-Shuqabi on terrorism charges related to his collaboration with known members of ISIS. AlShuqabi was arrested by the Tajoura Branch of the Central Support Forces, and he was referred to the GNA Attorney General for prosecution. 
- On December 13, the LNA-aligned Central Investigations Directorate in Benghazi arrested two men under the suspicion of smuggling funds for terrorist financing purposes in support of ISIS in cooperation with an Egyptian national. Following the arrests, firearms and ammunition were recovered at the suspects' homes. Both men confessed to the allegations, identifying two other suspects in the process, and their files were transferred to the public prosecutor in Benghazi.

Countering the Financing of Terrorism: Libya is a member of MENAFATF. Libya is also a member of the Defeat-ISIS Coalition's CIFG. There were no significant updates in 2019.

Countering Violent Extremism: There were no changes in 2019.

International and Regional Cooperation: International assistance continued in 2019, although the outbreak of conflict for Tripoli in April forced many donor nations to curtail assistance efforts or conduct assistance outside Libya. Libya is a member of the UN, the AU, the Organization of Islamic Cooperation, and the Arab League, and it has participated in regional workshops administered by the UN.

\section{MOROCCO}

Overview: The United States and Morocco have robust and long-standing CT cooperation. The Government of Morocco continued its comprehensive CT strategy that includes vigilant security measures, regional and international cooperation, and counter-radicalization policies. In 2019, Morocco's CT efforts largely mitigated its risk of terrorism, doubling the number of arrests compared with 2018. The country continued to face sporadic threats, largely from small, independent terrorist cells, the majority of which claimed to be inspired by or affiliated with ISIS. In March 2019, Morocco repatriated eight FTFs from Syria. Morocco is an active participant in the Global Coalition to Defeat ISIS. Morocco is also a member of the GCTF and is currently the co-chair of the GCTF with Canada.

2019 Terrorist Incidents: There were no terrorist incidents reported in Morocco in 2019.

Legislation, Law Enforcement, and Border Security: Morocco continued to investigate, prosecute, and sentence defendants under its CT legislation, enacted in 2003 and expanded in 2015.

In 2019, Morocco's Council of Ministers approved a draft law to manage trade in dual-use goods, which would give Moroccan law enforcement authority to control the import, export, and transit of dual-use goods and related services that could be used for WMD proliferation related purposes, to include the development of a WMD program.

In 2019, under the direction of the Ministry of Interior, Moroccan law enforcement aggressively targeted and reported to have arrested more than 125 individuals, effectively dismantling more than 25 terrorist cells in the early stages of planning attacks against a range of targets, including public buildings, public figures, and tourist sites. Moroccan law enforcement leveraged intelligence collection, police work, and collaboration with international partners to conduct CT 
operations. Three men who murdered two Scandinavian hikers in the Atlas Mountains in 2018 were sentenced to death in July 2019 (though Morocco has had a moratorium on executions since 1993), while a fourth man received a life sentence.

The Central Bureau of Judicial Investigation (BCIJ) remains the primary law enforcement agency responsible for CT prosecutions. The BCIJ reports to the General Directorate for Territorial Surveillance and operates under the supervision of the public prosecutor of the Court of Appeals. The following offers a snapshot of arrests in 2019:

- In January, Moroccan authorities dismantled a 13-person cell for inciting terrorist crimes and undermining the state's security in the cities of, Casablanca, Mohammedia, and Sale, seizing electronic devices, bladed weapons, and a written pledge of allegiance to ISIS.

- In May, Moroccan authorities dismantled a nine-member cell pledging allegiance to ISIS that planned to perpetrate terrorist attacks in Tangier, seizing electronic devices, paramilitary uniforms, and harpoon guns.

- In October, Moroccan authorities dismantled a seven-person cell operating in Casablanca, Chefchaouen, and Ouazzane that was preparing to target sensitive infrastructure and strategic sites, seizing bladed weapons, diving equipment, and ISIS flags.

Border security remained a top priority for Moroccan authorities. The General Directorate for National Security has primary responsibility for conducting border inspections at ports of entry such as Casablanca's Mohammed V Airport. Law enforcement officials and private airline carriers worked regularly with the United States to detect and deter individuals attempting to transit illegally and to address watchlisted travelers. Moroccan airport authorities have excellent capabilities in detecting fraudulent documents. In addition, police, customs officers, and the Royal Gendarmerie operated mobile and fixed checkpoints along the roads in border areas and at the entrances to major municipalities. Moroccan naval and coast guard units monitored and patrolled Morocco's extensive coastal waters, including the Strait of Gibraltar, to interdict illicit traffickers.

Countering the Financing of Terrorism: Morocco is a member of MENAFATF. Its FIU, known as the Unité de Traitement du Renseignement Financier, is a member of the Egmont Group. Morocco is also a member of the Defeat-ISIS Coalition's CIFG. In August, MENAFATF published a Mutual Evaluation Report that reviewed Morocco's compliance with FATF standards and the effectiveness of Morocco's AML/CFT system; the report contained several recommendations to enhance its AML/CFT regimes.

Countering Violent Extremism: Morocco has a comprehensive CVE strategy that prioritizes countering radicalization and oversight of the religious sphere. To counter what it views as religious extremism, Morocco promotes an interpretation of the Maliki-Ashari school of Sunni Islam, which it considers tolerant. The Ministry of Endowments and Islamic Affairs has developed an educational curriculum for Morocco's nearly 50,000 imams, as well as for female clerics (mourchidates). In 2019, Morocco's imam training center in Rabat trained more than 2,700 religious leaders, mostly from West Africa, which included more than 400 women graduates. The Royal Mohammedan League of Ulema (Rabita Mohammedia) counters 
radicalization by producing scholarly research, reviewing educational curricula, and conducting youth outreach on religious and social topics.

In prisons, the U.S. Department of State has supported the General Delegation for Prison Administration and Reintegration's (DGAPR's) efforts to modernize prison management, develop prisoner classification tools, and construct more secure facilities. The DGAPR has conducted four offerings of its deradicalization program, Moussalaha (Reconciliation) and plans to open the program to female prisoners in 2020.

International and Regional Cooperation: Morocco is currently a co-chair of the GCTF with Canada. Morocco hosted one GCTF event in June 2019, an Africa-focused regional workshop on the "Initiative on Improving Capabilities for Detecting and Interdicting Terrorist Travel through Enhanced Terrorist Screening and Information Sharing," an initiative that Morocco cochaired with the United States. Morocco also participated in UN-led workshops on detecting and preventing terrorist travel. Morocco is a major non-NATO ally. Morocco hosted the annual African Lion exercise and participated in multilateral regional training exercises. Morocco is an active member of the TSCTP. Morocco also has strong cooperation with European partners especially Belgium, France, and Spain - to thwart potential terrorist threats in Europe. Regional tensions between Morocco and Algeria remained an impediment to CT cooperation in 2019.

\section{OMAN}

Overview: Oman is an important regional CT partner that actively worked in 2019 to prevent terrorists from conducting attacks or using the country as a safe haven. The Omani government remains concerned about the conflict in Yemen and the potential for al-Qa'ida in the Arabian Peninsula and ISIS-Yemen to threaten Oman's land and maritime borders. Omani officials regularly engaged with U.S. officials on the need to counter terrorism, but rarely broadcast their CT efforts publicly. The Government of Oman sought training and equipment from the U.S. government, commercial entities, and other countries to support its efforts to control Omani land, air, and maritime borders. Oman also used U.S. security assistance to improve its crisis management capacity, as well as its CT tactics and procedures. Oman is a member of the Global Coalition to Defeat ISIS, the Saudi-led Islamic Military Counter Terrorism Coalition (IMCTC), and the Riyadh-based TFTC. The Government of Oman also issued several statements condemning terrorist attacks around the world in 2019.

2019 Terrorist Incidents: There were no terrorist incidents reported in Oman in 2019.

Legislation, Law Enforcement, and Border Security: Oman did not promulgate new laws related to penalties for terrorist activity in 2019 but continued to implement the penal code released by Royal Decree 7/2018 in January 2018. This code expands on previously established penalties and specifically stipulates imprisonment for a term of three to 15 years for any Omani citizen who joins or offers either material or "ideological" support to a foreign terrorist or "extremist" organization. Other provisions in the penal code are consistent with previous policies outlining penalties, including the death penalty and life imprisonment, for various terrorist acts, including establishment or leadership of a terrorist group, attempts to join a 
terrorist group, attempts to recruit for a terrorist group, development of an explosive or weapon, or takeover of any mode of transportation for purposes of terrorism.

CT investigations, crisis responses, and border security capabilities were limited by local capacity and an operating environment made challenging by Oman's extensive coastline and long, remote borders with Saudi Arabia and Yemen. Nevertheless, Oman had adequate communication and coordination among its many agencies that have CT jurisdiction. The Sultan's Special Forces and the Royal Oman Police Special Task Force are Oman's primary CT response forces. The Royal Office Liaison and Coordination Service and the Internal Security Service also play key roles in securing Oman from terrorist threats. Omani authorities have developed specific plans to prevent or respond to terrorist attacks against soft targets.

The major impediments to more effective law enforcement and border security are limited resources, insufficient Omani interagency coordination, and the need for continued training to develop advanced law enforcement skills. The rugged, mountainous terrain along Oman's border with Yemen is an additional challenge. To address these significant hurdles, Omani authorities continued construction of a fence along the border with Yemen to prevent illegal entry into Oman, and the Omani government continued to seek opportunities for additional U.S. border security training.

Countering the Financing of Terrorism: Oman is a member of MENAFATF. Its FIU, known as the Financial Information Processing Unit, is a member of the Egmont Group. Oman is also a member of the TFTC.

In collaboration with other TFTC member states, Oman in 2019 imposed one round of sanctions against individuals and entities affiliated with the Iranian regime's terror-support networks in the region. In November, the Central Bank of Oman, the National Committee to Combat Money Laundering and Terrorism Finance, and the National Committee for Combating Terrorism met to strategize about enhancing protections against money laundering in Oman.

In December, Omani officials participated in a DOJ-led workshop focused on disrupting terrorist and criminal funding mechanisms through effective online undercover investigations.

Countering Violent Extremism: The full nature and scope of Oman's CVE initiatives remained opaque in 2019, but it is believed Oman continued to counter terrorist recruitment through tightly controlled, private initiatives.

In 2019, Oman's Ministry of Endowments and Religious Affairs continued to encourage religious tolerance and interfaith dialogue through a program titled "Tolerance, Understanding, Coexistence - Oman's Message of Islam." After facilitating several events in Europe in 2018, the ministry promoted the initiative in 2019 through exhibitions in the United States, Indonesia, and Nepal. 
International and Regional Cooperation: In April, the IMCTC announced that 13 member countries, including Oman, sent delegates to the IMCTC headquarters in Riyadh. Oman regularly votes in favor of CT measures in the UN General Assembly, the Arab League, and the Organization for Islamic Cooperation.

\section{QATAR}

Overview: The United States and Qatar continued to increase CT cooperation in 2019, building on progress made after the U.S. Secretary of State and Qatari Foreign Minister signed a CT MOU in July 2017. At the U.S.-Qatar Counterterrorism Dialogue in November 2019, the two governments declared their fulfillment of the MOU largely complete and committed to set shared priorities for 2020. Qatar is an active participant in the Global Coalition to Defeat ISIS, is active in all Defeat-ISIS Coalition working groups, and facilitated U.S. military operations in the region. Qatar hosts roughly 10,000 U.S. service members on two military installations critical to Coalition efforts.

2019 Terrorist Incidents: There were no terrorist attacks reported in Qatar in 2019.

Legislation, Law Enforcement, and Border Security: In 2019, the Qatari government drafted new AML/CFT legislation, which was finalized and passed into law on September 11, 2019. As of late 2019, Qatari authorities were in the process of finalizing AML/CFT bylaws, as well as a new CT law that will include language on targeted financial sanctions.

Qatar maintains an interagency National Anti-Terrorism Committee (NATC) composed of representatives from more than 10 government agencies. The NATC is tasked with formulating Qatar's CT policy, ensuring interagency coordination, fulfilling Qatar's obligations to counter terrorism under international conventions, and participating in multilateral conferences on terrorism. U.S. officials met regularly with the chairman of the NATC to discuss implementation of the CT MOU and overall CT cooperation. The Qatar State Security Bureau (SSB) maintained an aggressive posture toward monitoring internal terrorism-related activities. The Ministry of Interior (MOI) and Internal Security Force (ISF) remained well positioned to respond to incidents with rapid reaction forces that routinely engage in structured CT training and exercises, including with U.S. agencies. Qatar's Office of Public Prosecution was active in developing its new units devoted to prosecuting terrorism and CFT cases.

As a result of the CT MOU signed in 2017, the United States and Qatar continued to partner on terrorist screening and aviation security. In 2019, MOI authorities continued to cooperate with officials from the U.S. Department of Homeland Security's Customs and Border Protection and Transportation Security Agency to enhance screening capabilities of the estimated 30 million travelers who pass through Hamad International Airport each year.

U.S. technical assistance to Qatari law enforcement and judicial agencies increased during 2019. The U.S. Departments of Justice, State, and the Treasury, as well as the FBI, led or participated in several capacity-building initiatives involving the MOI, the ISF, the SSB, the Public Prosecution, the Central Bank, and other Qatari agencies. A DOJ resident legal advisor has been stationed in Qatar since April 2018, providing technical assistance to Qatar's CT efforts and 
building prosecutorial capacity. In November 2018, Qatar began using its own funds to pay for a three-year U.S. Department of State Anti-Terrorism Assistance (ATA) training program, including training pertinent to Qatar's preparations to host the FIFA World Cup in 2022; the primary recipients are MOI and ISF officers.

Countering the Financing of Terrorism: Qatar is a member of MENAFATF. Its FIU, known as the Qatar Financial Information Unit, is a member of the Egmont Group. Qatar is also a member of the Defeat-ISIS Coalition's CIFG and the TFTC.

In collaboration with other TFTC member states, Qatar in 2019 imposed one round of sanctions against individuals and entities affiliated with the Iranian regime's terror-support networks in the region.

The Qatari government passed a new AML/CFT law in 2019 and sought feedback from the International Monetary Fund and the U.S. government during the drafting process. Qatar continued to maintain restrictions, imposed in 2017, on the overseas activities of Qatari charities, requiring all such activity to be conducted through one of two approved charities in an effort to better monitor charitable giving for terrorist financing abuse.

Countering Violent Extremism: The core of Qatar's CVE strategy remained intensive investment in education and increasing economic opportunities for youth around the globe, largely through Qatar Foundation and related organizations, such as Silatech, Education Above All, and Reach Out to Asia. Qatar cohosted a high-level event promoting the power of sport to prevent and counter terrorist radicalization and recruitment on the margins of UN General Assebmly in September 2019. Qatar has made significant strides in addressing state-sourced internal and external support for educational and religious content espousing intolerance, discrimination, sectarianism, and violence, although examples are still found in textbooks and disseminated through satellite television and other media.

Qatar was also a major funder of GCERF and sits on its Governing Board of Directors. The Qatar Fund for Development supported GCERF's efforts to build awareness among community leaders about the impact of terrorist radicalization and recruitment, share information on how to respond to terrorism, promote peace through community engagement activities, and provide educational initiatives.

Qatar's Ministry of Education and Higher Education (MEHE) also supported English language programming in Ministry of Education schools as a means of countering terrorist influence and messaging. MEHE facilitated extracurricular English reading and writing workshops in primary schools. In November 2019, the Qatar National Library co-hosted an "open mic" event for high schoolers to promote critical thinking, tolerance, and peaceful expression.

International and Regional Cooperation: Qatar is an active CT participant in the UN, the Organization of Islamic Cooperation, and the Arab League. Qatar is also a member of the GCTF and a major contributor to GCERF. The country was active in GCC activities, but the Gulf dispute that broke out in June 2017 froze most GCC-wide engagements. Qatar continues to participate, however, in TFTC activities in Riyadh. 


\section{SAUDI ARABIA}

Overview: In 2019, Saudi Arabian government officials continued to work closely with their U.S. counterparts to deploy a comprehensive and well-resourced CT strategy that included vigilant security measures, regional and international cooperation, and measures to counter terrorist radicalization and recruitment. Saudi Arabia maintained a high cooperation tempo with U.S. and international partners in a range of CT fields, including terrorist information sharing, monitoring of FTFs, border security, countering unmanned aerial systems (UAS), and CVE. The Saudi Arabian government worked to disrupt, and supported U.S. and international sanctions against, terrorist finance networks, focusing heavily on entities supporting Iran's IRGC-QF, Lebanese Hizballah, and other Iranian proxy groups active in the Gulf.

Attacks by Iran on September 14 targeted some of the Kingdom's most important oil-processing facilities at Abqaiq and Khurais. Saudi authorities moved quickly to bolster the facilities' security posture, restore oil processing and export capacity, and repair damaged infrastructure. To help deter Iranian aggressive behavior and enhance Saudi capacity, Saudi Arabia agreed to host U.S. service members.

As in previous years, Saudi Arabia was a full partner and active participant in the Global Coalition to Defeat ISIS and provided significant operational and logistical support for Coalition activities in Syria and Iraq. Saudi operations in Yemen included CT missions against AQAP and ISIS.

2019 Terrorist Incidents: Saudi Arabia suffered from numerous terrorist incidents in 2019. Terrorist incidents included both external attacks by Iranian and Houthi actors and small-scale attacks, largely perpetrated by lone offender actors including ISIS sympathizers. Militants instigated violence using IEDs, gunfire, and UAS. Attacks in 2019 included:

- On April 7, two suspected terrorists were killed and another two arrested by Saudi security forces when they attacked a vehicle checkpoint in Abu Hadriya on the Dammam-Jubail highway. Two non-Saudi civilians were injured in the exchange of gunfire between the suspects and Saudi security forces. Two Saudi security officials also sustained injuries.

- On April 21, Saudi security officials killed four suspected terrorists in a failed terrorist attack on a Ministry of Interior building in the town of Al Zulfi, Riyadh Province. The militants detonated an explosive suicide belt, and three Saudi security officials were injured in the exchange of fire. ISIS claimed responsibility for the attack.

- On May 14, unmanned aircraft systems targeted two pumping stations on the East-West pipeline carrying crude oil from Dhahran to Yanbu. Yemen-based Iran-backed Houthi militants claimed responsibility.

- On June 12, Saudi-led coalition senior officials reported a cross-border cruise missiles attack at Abha International Airport, injuring 26 civilians. Yemen-based Iran-backed Houthi militants claimed responsibility for this attack. 
- On August 17, Yemen's Iran-backed Houthi militants struck a natural gas liquids plant at Shaybah oilfield in the Kingdom's Empty Quarter with drones. The drone strike damaged the facility and caused a fire. No deaths or casualties were reported.

- On September 14, Iranian attacks hit the Abqaiq and Khurais oil processing facilities in the Eastern province, initially taking 5.7 million barrels per day of crude oil production offline. Although Yemen's Iran-backed Houthi militants claimed responsibility for the attack, investigations led by Saudi Arabia and the United States concluded the Iranian government was behind the attack. Saudi Aramco resumed pre-attack production levels less than two weeks later, ahead of schedule.

In addition, on December 6, 2019, a member of the Royal Saudi Air Force opened fire in a classroom at Naval Air Station Pensacola in Florida, killing three and wounding eight. The gunman, 2nd Lt Mohammed Saeed Alshamrani, was a student who was receiving training at the base. The FBI later noted that Alshamrani had coordinated with AQAP before the terrorist attack, for which the latter claimed credit. The Government of Saudi Arabia continues to work closely with the United States on the investigation.

Legislation, Law Enforcement, and Border Security: In 2019, the Saudi Arabian government used its 2017 counterterrorism law to prosecute cases. The State Security Presidency (SSP) and the Saudi General Investigations Directorate, also known as the Mabahith, took the lead in terrorism-related investigations. Well positioned to respond to incidents, the SSP aggressively investigated terrorist suspects and dismantled suspected ISIS terrorist-related cells within its borders. According to press reports, the Specialized Criminal Court, tasked with judicial oversight of criminal hearings, heard several terrorism-related cases. The court sentenced 38 convicts to death for terrorism-related crimes, with one Yemeni executed on April 9 and 37 Saudis executed on April 23. Some international human rights and press groups continued to assert that the Kingdom has misused counterterrorism laws to prosecute religious and political dissidents, women's rights activists, and prominent Saudi clerics. Saudi Arabia remained a country of particular concern, a designation it has held since 2004 for systematic violations under the International Religious Freedom Act, including for repression of religious freedom and religious minorities. The Anti-Defamation League and other human rights organizations reported that Saudi textbooks, media, and preaching continued to feature content that condones violence against Jews, Christians, Shia, LGBT persons, and others. See the 2019 International Religious Freedom report.

Saudi Arabia remained committed to securing its borders and denying safe haven to terrorists. With an extensive border security network, the Ministry of Interior closely monitored passenger manifests for inbound and outbound flights and used travel document security technology, API/PNR, and biometric screening capabilities at ports of entry. The General Directorate of Border Guards expanded search operations to detect and disrupt terrorist activity and effectively patrolled land and maritime borders. Officials from the Saudi Border Guards, charged with monitoring the coast within the Kingdom's territorial waters, called for international agreements to combat the growing threat of maritime terrorism targeting oil tankers and coastal installations in the Gulf. 
Countering the Financing of Terrorism: Saudi Arabia is a member of FATF and MENAFATF. Saudi Arabia became the first Arab nation to achieve full membership in the FATF in June. Its FIU, known as the Saudi Arabia Financial Investigation Unit, is a member of the Egmont Group. Saudi Arabia is also a member of the Defeat ISIS CIFG and the TFTC.

In collaboration with other TFTC member states, Saudi Arabia in 2019 imposed one round of sanctions against individuals and entities affiliated with the Iranian regime's terror-support networks in the region.

Countering Violent Extremism: Crown Prince Mohammed bin Salman's Vision 2030 reform package calls on all ministries to undertake measures to confront and weaken the violent ideology that underpins terrorist propaganda. The Muslim World League Secretary General, Dr. Mohammed al-Issa, pressed a message of interfaith dialogue, religious tolerance, and peaceful coexistence with global religious authorities, including Muslim imams outside the Arab world. He also conducted outreach with a variety of Jewish and Christian leaders, including prominent U.S. rabbis and Christian evangelicals.

Saudi Arabia has recently initiated lines of CVE effort to foster reform and regulate religious activities. The government reported that it continued to work to constrain the discriminatory content of its education, satellite, and religious advocacy output both overseas and domestically. Nevertheless, its decades-long support for organizations that propagated intolerant interpretations of Islam overseas remained a concern, as did uneven implementation of educational content reform. Ministry of Islamic Affairs officials continued to conduct outreach to imams across the country, encouraging them to refute "radical extremist" ideology in their sermons and replacing imams who included inflammatory rhetoric in their mosque sermons. Through routine monitoring of terrorist websites and social media accounts, authorities attempted to dispel what the Saudi government views as misinterpretations of Islamic theology. In 2019, there also was an increased emphasis on family outreach mechanisms to reduce the risk of travel to conflict zones to avoid terrorist radicalization or participation in terror-related activities. Terrorist deradicalization programs in Saudi prisons and at the Mohammed bin Naif Care and Counseling Center remained a main feature in the reintegration and monitoring of former terrorists.

International and Regional Cooperation: Saudi Arabia's regional diplomatic efforts to fight terrorism saw a strong uptick in 2019, as the country partnered with several nations on a bilateral and regional basis to improve information sharing related to CT activities. Through the UN Counter-Terrorism Center, the GCTF, and the Gulf Cooperation Council, the Saudi Arabian government worked to strengthen capacity and monitor new terrorist trends through policy coordination, capacity building, and operational collaboration with international partners. Saudi Arabia signed multiple CT MOUs with international partners and hosted three diplomatic conferences - the Makkah Summit, the Organization of Islamic Cooperation Summit, and the Arab Summit - all of which included counterterrorism discussions. Saudi Arabia is a member of the Global Coalition to Defeat ISIS. 


\section{TUNISIA}

Overview: Although the risk of terrorist activity in Tunisia remained high in 2019, the Tunisian government's improved counterterrorism capacity and coordination, as well as its prioritization of border security, contributed to a reduction in the number and severity of terrorist attacks. The dual suicide attack on June 27 by ISIS-inspired individuals was the most ambitious of 2019, but the Tunisian government's response was well orchestrated and quickly restored public calm and resulted in arrests. The increased number of successful CT operations throughout 2019, including the killing of Jund Al Khilafah leader Houssem Thelithi Mokni, reflected greater interagency coordination, improved preemptive planning, and sustained momentum in dismantling terrorist cells.

The government continued to prioritize counterterrorism and border security in light of escalated Libyan instability and political uncertainty in Algeria. U.S security assistance increased in 2019, and Tunisia leveraged cooperation with the United States and the international community to continue to professionalize its security apparatus. Tunisia grew its overall CT capacity, outlined ways to implement a national PVE/CVE strategy, and expanded its freezing of terrorist assets. As fundamental CT goals are being met, Tunisia will need time and continued support to focus on streamlining its CT efforts, to expand strategic planning, and to enhance interagency coordination to sustain gains and ensure mid- to long-term force sustainability.

2019 Terrorist Incidents: Terrorist organizations remained active; however, their ability to carry out effective attacks was degraded by improved coordination and capacity of Tunisian security forces. Lone wolf attacks continued to pose a challenge to security forces. The following list summarizes the most significant terrorist incidents of 2019:

- On April 26, during a Tunisian Armed Forces CT mission in the Chaambi Mountains, a landmine exploded near a military vehicle, killing one soldier and wounding three.

- On June 27, two suicide bomb attacks struck central Tunis, targeting a police vehicle downtown and the office of the Ministry of Interior's National Police CT Investigative Unit nearby. The former attack led to the death of one municipal policeman and wounding three civilians; the latter injured three security officers and killed one. ISIS claimed responsibility for the attacks.

- On September 23, an individual acting alone stabbed a military officer near a bus stop and proceeded to fatally stab a police officer near a courthouse in Bizerte.

Legislation, Law Enforcement, and Border Security: In 2019, there were two legislative initiatives related to countering terrorism. On January 10, the Parliament ratified amendments to the 2015 Countering Terrorism and Money Laundering Law. With the amendments, the law now legally defines perpetrators of terrorist crimes, integrates juvenile justice into the Judicial Center for Combating Terrorism (POLE), and grants new powers to the National CounterTerrorism Commission (CNLCT), including the decision to freeze the assets of persons suspected of terrorism-related crimes. On May 17, the Tunisian government issued Decree 419 titled "UN Measures to Prevent Terrorists from Acquiring Weapons of Mass Destruction," which, in addition to outlining steps to implement UN Security Council measures related to CT 
and counter-WMDs, extended the CNLCT's authority to sanction persons or organizations engaged in material support for terrorism.

The government's CT efforts demonstrated notable increases in proactive CT operations and improved coordination between Ministry of Interior (MOI) and Ministry of Defense security elements in 2019, resulting in significant arrests of terrorists, weapons seizures, and successful operations. Major law enforcement actions and arrests included:

- On January 3, police officers engaged two terrorists belonging to Katibat Al Jihad Wal Tawheed, a recent splinter of Jund Al Khilafah, in Sidi Bouzid governorate. Both individuals died after detonating their explosive belts. Security officials seized a machine gun, remote-controlled IEDs, hunting rifles, ammunition, and a large sum of money.

- On March 19, MOI security forces carried out a pre-emptive security operation against Jund Al Khilafah on Mount Salloum, Kasserine governorate, killing its leader, Houssem Thelithi Mokni, and two other members. The unit seized three firearms, ammunition, several detonators, grenades, and explosive belts.

- On May 1, a joint preemptive operation involving MOI security forces on Chaambi Mountain, Kasserine governorate, resulted in the capture of Raed Touati, a member of AQIM-aligned Uqba Ibn Nafaa.

- During June 27-28, in response to the twin suicide attacks in Tunis, security units conducted 493 raids resulting in the arrest of 25 wanted elements on the suspicion of belonging to a terrorist organization, glorification of terrorism, and terrorist offenses. These arrests helped uncover a plot targeting Carthage Airport.

- On September 2, National Guard units in coordination with the Tunisian military conducted a CT operation west of Kasserine, killing three terrorists and seizing four rifles and three suicide belts. One National Guard officer died. According to the CT Judicial POLE, the three terrorists were Algerian nationals wanted since 2013.

- On October 20, National Guard units in coordination with the Tunisian military conducted a CT operation in Kasserine, killing one terrorist, Algerian national Mourad Ben Hamadi Chayib.

- During November 27-28, Tunisian security forces discovered a cache of more than six thousand rounds of 7.62-calibre ammunition buried in the desert outside the southwestern city of Douz.

Border security remained a top emphasis of the Government of Tunisia in 2019 because of escalation in fighting in Libya and Algeria's uncertain political transition. The Tunisian Armed Forces consider border security their principal mission along with CT. Along with the MOI's National Guard, the Armed Forces successfully employed patrol craft, vehicles, weapons, and training in border security and CT operations throughout 2019. On April 11, the southern electronic border surveillance system operation room in Gabes came online. On October 3, a maritime coastal surveillance system operation center in Kelibia was inaugurated. The complete maritime surveillance system will provide coverage across the entire Tunisian coast.

According to the Ministry of Tourism, 8.3 million tourists visited Tunisia from January to November 2019, a 14 percent increase over the same period last year. The most recent terrorist attack against tourists in Tunisia was in 2015. Safeguarding tourist zones remained a Tunisian 
government priority in 2019. Within the context of the G-7 mechanism for multilateral security assistance coordination, the UK-led Tourist Site Protection working group provided the MOI with vehicles for use near tourist beaches in Monastir, Nabeul, and Sousse, and helped train 81 security agents to work at archeological sites in 2019.

Countering the Financing of Terrorism: Tunisia is a member of MENAFATF. Its FIU, known as the Tunisian Financial Analysis Committee, is a member of the Egmont Group. Tunisia is also a member of the Defeat ISIS Coalition's CIFG and successfully completed its FATF action plan and the FATF removed Tunisia from its grey-list at the October 2019 plenary meeting in Paris.

On October 25, the CNLCT announced there were 138 Tunisians on the national list of "Individuals, Organizations and Entities Related to Terrorist Crimes." Of these, 107 Tunisians were residing domestically, 26 lived abroad, and five had fled to neighboring countries. The total value of frozen assets amounts to approximately $\$ 106$ million.

Countering Violent Extremism: In 2019, Tunisia continued its concerted effort to prevent what it terms "radicalization" through youth and educational programs coordinated among its ministries and civil society organizations (CSOs). On April 8, the Alternative Narrative Platform, an office within the Prime Ministry, launched its national CVE action plan in partnership with the Tunisian Broadcasting Institute to promote messages of tolerance, diversity, and acceptance across mass media platforms. In October, the Ministry of Justice launched its Tawasol Project with assistance from the European Union, the Netherlands, and the UK. The program will work with 60 prisoners in three prisons as a pilot to classify prisoners, teach communication techniques against "extremism," and create prison research/vocation centers for inmate education. The MOJ intends to expand the project to all its prisons by 2028.

International and Regional Cooperation: Tunisia will assume a seat during 2020 to 2021 on the UN Security Council representing both Africa and the Middle East, and it has been a participant in UN-led training on detecting and preventing terrorist travel.

\section{UNITED ARAB EMIRATES}

Overview: The United Arab Emirates government continued to prosecute multiple individuals for terrorism-related offenses in 2019. In line with previous years, the UAE continued its collaboration with U.S. law enforcement on counterterrorism cases; its membership in the Global Coalition to Defeat ISIS; and its support for CVE and related platforms, such as the Sawab and Hedayah Centers, respectively. The UAE remained co-chair of the Defeat-ISIS Coalition's Communications Working Group, along with the United States and the United Kingdom, as well as co-chair of the Defeat-ISIS Coalition's Stabilization Working Group with the United States and Germany.

The government's security apparatus continued monitoring suspected terrorists in the UAE and foiled potential terrorist attacks within its borders. The UAE customs, police, and other security agencies improved border security and worked with financial authorities to counter terrorist finance. UAE government officials worked closely with U.S. law enforcement counterparts to 
increase the UAE's CT capabilities. The UAE continued to support counterterrorism efforts in Yemen to counter AQAP and ISIS, including support to local forces in CT operations. The drawdown of some UAE forces in Yemen and disbanding of some local security forces supported by the UAE following conflict between the Republic of Yemen Government and forces aligned with the Southern Transitional Council contributed to a reversal of territorial gains in the fight against AQAP and ISIS in Yemen, including in areas known to be historical safe havens for the groups.

2019 Terrorist Incidents: There were no terrorist attacks reported in the UAE in 2019.

Legislation, Law Enforcement, and Border Security: In 2019, the UAE continued to prosecute numerous individuals in terrorism-related cases using existing legislation. International human rights NGOs and activists reported the UAE uses its CT and cyber-crime laws as cover to pursue cases against political dissidents and activists.

The State Security Directorate (SSD) in Abu Dhabi and Dubai State Security (DSS) remained primarily responsible for CT law enforcement efforts. Local, emirate-level police forces, especially Abu Dhabi Police and Dubai Police, are the first responders in such cases and often provided technical assistance to SSD and DSS, respectively. Overall, the UAE security apparatus demonstrated capability in investigations, crisis response, and border security, and forces were trained and equipped to detect, deter, and respond to terrorist incidents.

According to press reports, the Federal Appeal Court's State Security Court examined new terrorism-related cases in 2019 and retried terrorism-related cases from 2018. Most cases involved defendants accused of promoting or affiliating with UAE-designated terrorist organizations, including ISIS, AQAP, and al-Nusrah Front.

As in previous years, the Government of the UAE worked closely with the United States, through DHS, to improve its border security posture. Law enforcement information sharing between Abu Dhabi Police's Criminal Investigations Division and DHS Homeland Security Investigations helped counter transnational criminal organizations and terrorist groups. UAE ports of entry used an internal name-based watchlist system populated by local immigration, deportation, corrections, and security agencies to identify individuals who were prohibited from entering the country or were sought by UAE authorities. Some human rights organizations claimed that activists, academics, and journalists who had written critically about UAE policy were included on such lists and barred from entry. INTERPOL and GCC watchlists were incorporated into the UAE's internal watchlist.

Countering the Financing of Terrorism: The UAE is a member of MENAFATF. Its FIU, known as the Anti-Money Laundering and Suspicious Cases Unit (AMLSCU), is a member of the Egmont Group. The UAE is also a member of the Defeat ISIS Coalition's CIFG and the TFTC.

In collaboration with other TFTC member states, the UAE in 2019 imposed one round of sanctions against individuals and entities affiliated with the Iranian regime's terror-support networks in the region. 
The UAE passed Cabinet Decision No. 10 of 2019, also known as the Implementing Regulation of Decree Federal Law No. 20 of 2018, on Anti-Money Laundering and Combating the Financing of Terrorism and Illegal Organizations and provided interpretive guidance to financial institutions on these regulatory changes.

The Central Bank of the UAE (CBUAE) announced a new initiative to supervise financial institutions sanctions screening capabilities. Starting in the first quarter of 2020, CBUAE will use its own sanctions screening software as a baseline to test the sanctions screening capabilities of all UAE financial institutions regulated under the authority of the CBUAE.

In partnership with UNODC, the AMLSCU launched an online platform called goAML to facilitate the receipt, analysis, and dissemination of suspicious transactions and activity reports related to money laundering and the financing of terrorism, to UAE law enforcement authorities.

Countering Violent Extremism: The UAE government continued to play a leadership role in global CVE efforts. The UAE continued its support of Hedayah, the International Center of Excellence for Countering Violent Extremism, and the Sawab Center, a collaborative partnership with the United States to amplify credible voices to counter terrorist messaging online. The government separately worked to amplify credible alternative narratives by supporting the fifth annual Forum for Promoting Peace in Muslim Societies, which gathered 800 scholars and religious figures from 120 countries. Prominent UAE officials and religious leaders continued to publicly criticize and highlight the dangers of terrorist narratives. Through the General Authority of Islamic Affairs and Endowments, the government regulated all mosque sermons and religious publications to "instill the principle of moderation in Islam." The UAE continued efforts to provide "moderate" religious education training to educators and imams from Afghanistan.

The UAE declared 2019 the "Year of Tolerance" and organized public events at home and abroad to promote the values of tolerance, coexistence, and cooperation among peoples from all races and religions. The UAE cabinet approved a national initiative to promote the role of the government as an incubator for tolerance, and the Emirate of Dubai hosted the World Tolerance Summit. The UAE announced the construction of an "Abrahamic Family House" to promote interfaith harmony and commemorate the historic visit of Pope Francis to Abu Dhabi in February 2019.

International and Regional Cooperation: The UAE has signed CT cooperation agreements with Egypt, New Zealand, Russia, India, Germany, South Korea, and Brazil. The UAE government participated in several international conferences on combating terrorism, expressing the UAE's strategy and efforts in combating terrorism. The UAE hosted the annual Defeat-ISIS Coalition meeting in Abu Dhabi in October and an Arab League panel discussion on the role of media in combating terrorism in November. It also continued to play a role in countering AQAP and ISIS-Yemen through the deployment of forces in south Yemen. 
YEMEN

Overview: Throughout 2019, AQAP, ISIS-Yemen, Hizballah, the IRGC-QF, and other Iranbacked terrorist groups continued to exploit the political and security vacuum created by the ongoing conflict between the Yemeni government under the leadership of President Abd Rabu Mansour Hadi, recognized by the UN Security Council as the legitimate government of Yemen, and the Iran-backed Houthi militants. Additionally, IRGC-QF has exploited the conflict to expand its influence in Yemen. UN and other reporting have highlighted the connection between the IRGC-QF and the Houthis, including the provision of lethal aid used by the Houthis to target civilian sites in Saudi Arabia and the UAE. Media reports suggest that other FTOs, such as Hizballah, may also be supporting the Houthi militants.

The Republic of Yemen Government, in partnership with the Saudi-led coalition, controlled the majority of Yemeni territory at the end of 2019; however, in August the UAE-backed secessionist Southern Transitional Council (STC) seized control of the Republic of Yemen Government's temporary capital, Aden. With the November 5 signing of the Riyadh Agreement between the Republic of Yemen Government and the STC, the two parties agreed to end three months of hostilities in Yemen's South. The agreement allowed for the return of the Republic of Yemen Government prime minister to Aden on November 18. It also aims to produce a more inclusive, representative cabinet and bring all military forces under the Republic of Yemen Government umbrella. Iran-backed Houthi militants controlled the capital of Sana'a and surrounding northwest highlands, and they largely controlled the port city of Hudaydah, among other areas. AQAP retained areas of influence inside Yemen, though the terrorist group was pushed back by Republic of Yemen Government and UAE-backed local security forces over the course of the year.

The Republic of Yemen Government cooperated with the U.S. government on CT efforts; however, because of the instability and violence in Yemen, as well as its own degraded capabilities, the Republic of Yemen Government cannot fully enforce CT measures across the country. A large security vacuum persists, which provides AQAP and ISIS-Yemen room to operate. Most counterterrorism gains in 2018 were reversed in 2019, as some UAE forces withdrew and other security forces supported by the UAE disbanded. Republic of Yemen Government and tribal pressures continued to complicate AQAP's freedom of movement. AQAP and ISIS-Yemen continued to carry out terrorist attacks throughout the country, including in government-held territory. UAE-backed Yemeni Security Belt Forces, which played a significant role in CT efforts, were used by the STC to exercise control over significant parts of Aden in August. The November 2019 Riyadh Agreement aims to bring them under Republic of Yemen Government control. ISIS-Yemen remained considerably smaller in size and influence compared with AQAP, but it remained operationally active and continued to claim attacks against AQAP, Yemeni security forces, and the Houthis militants.

2019 Terrorist Incidents: AQAP and ISIS-Yemen terrorists carried out hundreds of attacks throughout Yemen in 2019. Methods included suicide bombers, VBIEDs, ambushes, armed clashes, kidnappings, and targeted assassinations. Notable terrorist incidents from 2019 include: 
- On April 2, unknown gunmen kidnapped and killed a patient at Al Sadaqah hospital in Aden. The incident caused Doctors Without Borders to suspend all new admissions to the hospital.

- On August 1, ISIS-Yemen claimed responsibility for a suicide attack on a police station in Aden. The attackers used multiple suicide VBIEDs to attack a police station in Aden's Omar al Mokhtar neighborhood, killing 11 people and injuring 29 others.

- On August 2, AQAP gunmen stormed al-Mahfad army base in southern Abyan province, killing 19 soldiers.

Legislation, Law Enforcement, and Border Security: Yemen made no significant changes to its CT legal framework or to its law enforcement and border security procedures in 2019. Yemen does not have comprehensive CT legislation. Owing to a lack of resources and organization, police forces throughout the country struggle to exert authority.

Draft CT legislation has been pending in the Parliament since 2008. Before the political instability in Sana'a that drove the Republic of Yemen Government from the capital in 2015, the draft was under review by the three parliamentary subcommittees responsible for counterterrorism (Legal and Constitutional Affairs; Security and Defense; and Codification of Sharia Law). The law would facilitate the detention of suspects and include mandatory sentencing for several terrorism-related crimes. There have been no clear moves to implement legal structures compliant with UNSCRs 2178 and 2396 related to countering foreign terrorists and travel, although the Republic of Yemen Government continues to institute some noteworthy measures to combat terrorist travel. There are limited commercial flights operating out of airports in Yemen, and the government does not have the capacity or resources to implement UNSCR 2309 mandates on aviation security.

Before March 2015, Yemen's National Security Agency and President's Office drafted a National Counterterrorism Strategy. A ministerial committee reviewed the draft but was unable to finalize it because of political instability. Thus, Yemen's National Counterterrorism Strategy had not been officially adopted or implemented by the end of 2019.

Yemen employs the U.S.-provided PISCES system to secure borders and identify fraudulent travel documents. Despite the conflict, Yemen has been able to maintain traveler screening at a limited number of points of entry.

In past years, the Yemeni government's Coast Guard played a critical role in interdicting weapons and other illegal materials destined for Yemen-based terrorist groups, although the nation's maritime borders remained extremely porous. The central-southern coast remains highly vulnerable to maritime smuggling of fighters, weapons, materials, and goods used to support AQAP and ISIS-Yemen.

Countering the Financing of Terrorism: Yemen is a member MENAFATF.

In 2019, the Central Bank of Yemen committed to implementing International Monetary Fund Diagnostic Report recommendations to enhance AML/CFT capacity, but no specific steps have been undertaken to date. Owing to a lack of judicial capacity and territorial control, the Yemeni 
government is unable to fully implement UNSCRs related to terrorist financing. Since 2010, FATF has identified Yemen as a risk to the international financial system because of its strategic AML/CFT deficiencies.

The government has committed with the STC to enhance management of state revenues and announced in December the formation of a committee authorized to inspect and audit customs and tax collection points to ensure that funds were not diverted from government coffers.

Countering Violent Extremism: There were no significant changes in 2019.

International and Regional Cooperation: Yemen joined the Global Coalition to Defeat ISIS in 2019. The Republic of Yemen Government continued to cooperate with the GCC, the United States, and other donor countries as it concentrated on working toward a political solution to the conflict. Despite the challenges, the Republic of Yemen Government remained a dependable international partner as it worked to reestablish the rule of law within the territory it holds. Yemen, with the United States, the United Kingdom, the United Arab Emirates, and Saudi Arabia, participates in the Yemen Security Working Group, which includes military and diplomatic representatives from its three member states, and develops several cooperative capacity-building initiatives for Yemeni military and security forces. For example, in July, 15 Yemen Coast Guard personnel participated in a two-and-a-half week ship boarding and inspection course held in Aden and delivered by the UN's Office on Drugs and Crime's Global Maritime Crime Program. In addition, around 150 Yemen Border Guard members participated in five Export Control and Related Border Security-funded iterations of Yemen Border Interdiction Training in Riyadh. Yemen also belongs to the Organization of Islamic Cooperation and the Arab League.

\section{SOUTH AND CENTRAL ASIA}

Overview: In addition to continued terrorist activity in Afghanistan and Pakistan, South Asia in 2019 saw a volatile mix of insurgent attacks punctuated by major incidents of terrorism in the Indian state of Jammu and Kashmir and in Sri Lanka. A February 14 suicide bombing attack against an Indian paramilitary convoy in the Indian state of Jammu and Kashmir led to military hostilities and heightened tensions between India and Pakistan. Although ISIS lost the last remnants of its territory in Syria in March, it announced new branches in Pakistan and India in May and claimed responsibility for the Easter bombings in Sri Lanka in April.

Although al-Qa'ida in Afghanistan and Pakistan has been seriously degraded, key figures among AQ's global leadership, as well as its regional affiliate al-Qa'ida in the Indian Subcontinent (AQIS), continued to operate from remote locations in the region that historically served as safe havens.

Afghanistan continued to experience aggressive and coordinated terrorist attacks by ISIS's branch in the region, ISIS Khorasan Province (ISIS-K), and by the Afghan Taliban, including the affiliated Haqqani Network (HQN). Afghan National Defense and Security Forces (ANDSF) retained full responsibility for security in Afghanistan and, in partnership with NATO's Resolute Support Mission, took aggressive action against terrorist elements across Afghanistan. In 
offensives in late 2019, the ANDSF and the Taliban significantly degraded ISIS-K in Nangarhar province, denying ISIS territory, but the group continues to operate and regroup.

While Pakistan continued to experience terrorist attacks, there were fewer attacks and casualties than in 2018, continuing an overall decline. Pakistani military and security forces undertook CT operations against groups that conducted attacks within Pakistan, such as Tehrik-e-Taliban Pakistan (TTP), ISIS-K, and the Balochistan Liberation Army. Pakistan took modest steps in 2019 to counter terror financing and restrain India-focused militant groups from conducting large-scale attacks following the February attack on a security convoy in the Indian state of Jammu and Kashmir linked to Pakistan-based Jaish-e-Mohammed (JeM). Pakistan took action against some externally focused groups, including indicting Lashkar e-Tayyiba (LeT) founder Hafiz Saeed and associates in three separate terrorism financing cases.

However, Pakistan remained a safe harbor for other regionally focused terrorist groups. It allowed groups targeting Afghanistan, including the Afghan Taliban and affiliated HQN, as well as groups targeting India, including LeT and its affiliated front organizations, and Jaish-eMohammed (JeM), to operate from its territory. It took no notable action against known terrorists, such as JeM founder and UN-designated terrorist Masood Azhar and 2008 Mumbai attack "project manager" Sajid Mir, both of whom are believed to remain free in Pakistan. Pakistan, however, did make some positive contributions to the Afghanistan peace process, such as encouraging Taliban reductions in violence. Pakistan made some progress toward meeting the Action Plan requirements for the FATF, allowing it to avoid being blacklisted, but did not complete all Action Plan items in 2019.

In August, India amended the Unlawful Activities Prevention Act of 1967 to authorize the designation of individuals as terrorists - which it did a month later by designating four terrorists, including the leaders of LeT and JeM. The Indian Parliament also amended the National Investigation Agency (NIA) Act of 2008 to provide the NIA the ability to investigate terrorism cases overseas. The United States continues to build its strategic partnership with the Government of India, including through the bilateral Counterterrorism Joint Working Group meeting in March and the second 2+2 Ministerial Dialogue in December.

In April, ISIS-inspired terrorists conducted sophisticated suicide bombing attacks against churches and hotels across Sri Lanka on Easter Sunday, resulting in hundreds of deaths. It was a vivid example of ISIS's determination, after the loss of its so-called "caliphate" in Syria and Iraq, to continue the fight from its global branches and networks and by inspiring attacks.

In Maldives, the Solih administration continues to make progress bolstering its CT efforts. In July, President Solih announced Maldives' intent to facilitate the return and prosecution of Maldivian FTFs and families in Syria. The Maldivian government also passed an amendment strengthening its 2015 Anti-Terrorism Act and designated 17 terrorist organizations in September. In October, Maldivian police arrested Specially Designated Global Terrorist and ISIS recruiter Mohamad Ameen on "suspicion of spreading extremist ideology." 
In Bangladesh, ISIS-affiliated terrorists claimed six IED attacks, five of which were directed against Bangladesh police. ISIS's At-Tamkin media outlet released a Bangla-language propaganda video outlining its campaign against the Bangladesh government and other declared enemies.

Central Asian countries remained concerned about the potential spillover of terrorism from Afghanistan, as well as the potential threat posed by the return of their citizens who traveled to Iraq or Syria to fight with terrorist groups, including ISIS. Between January and June, the Kazakhstan government led the world in FTF repatriations by bringing back 595 Kazakhstani fighters and family members from Syria, prosecuting those suspected of participating in terrorist activity abroad, and providing rehabilitation and reintegration services to the remainder. Also in 2019, the Uzbekistan government repatriated 220 FTF family members from Iraq and Syria, mostly women and children, while the Tajikistan government repatriated 95 . The Kyrgyz Republic saw the return of about 300 FTFs and family members.

In November, ISIS claimed responsibility for an attack on the Tajik-Uzbek border. Through the C5+1 (the United States plus the Central Asian countries), officials from Kazakhstan, the Kyrgyz Republic, Tajikistan, Turkmenistan, and Uzbekistan participated in the associated C5+1 Security Working Group focused on regional cooperation on CT.

\section{AFGHANISTAN}

Overview: The United States partners with Afghanistan in a bilateral CT effort through Operation Freedom's Sentinel. The U.S. military, along with 38 other Coalition nations, also supports the ANDSF through the NATO Resolute Support "Train, Advise, and Assist" mission. In 2019, the Taliban and the affiliated HQN increased terrorist attacks targeting Afghan civilians, government officials, and members of the international community. Additionally, ISIS-K continued to attack civilians and especially targeted religious minorities. The enemy-initiated attack trend in 2019 defied its usual seasonal pattern; while in most years, such attacks decrease in cold-weather months, they remained consistently high following the summer fighting season. ISIS-K, elements of al-Qa'ida, including affiliate AQIS, and terrorist groups targeting Pakistan, such as TTP, continued to use the Afghanistan-Pakistan border region as a safe haven. Afghanistan is also the only member of the Global Coalition to Defeat ISIS from South and Central Asia.

2019 Terrorist Incidents: Attacks attributed to terrorist activity continued to increase in 2019. While the majority of attacks occurred in Kabul, Jalalabad, and other major population centers, incidents also targeted Highway 1 (Afghanistan's national Ring Road highway). Militants conducted high-profile attacks through complex assaults involving multiple attackers wearing suicide vests to target ANDSF, Afghan government buildings, foreign governments, and soft civilian targets to include international organizations. According to Resolute Support Mission reporting, between January 1 and September 30, insurgent and terrorist attacks were responsible for 1,618 civilians killed and an additional 4,958 wounded. Among the significant terrorist incidents in 2019 were: 
- On May 8, the Taliban attacked USAID-funded, U.S.-based aid organization Counterpart International in Kabul, killing four civilians and a policeman, and wounding 24 others. All attackers were killed after a six-hour battle with Afghan security forces.

- On July 1, a Taliban attack against the Afghan National Army Logistic and Armory Directorate involved a VBIED and five gunmen attacking the compound. The attack killed 40 civilians and wounded more than 100, including men, women, and children, in an adjacent school.

- On August 17, ISIS-K conducted a suicide bombing that targeted Shi' ite celebrants in a wedding hall in Kabul, killing at least 80 people and injuring more than 140.

- On September 2, the Taliban detonated a suicide car bomb at a facility in Kabul that housed numerous international organizations, killing 16 people and injuring more than 119. Those killed included five Nepalis, two Britons, and a Romanian diplomat.

- On September 5, the Taliban detonated a suicide car bomb in Kabul killing 12 people, including an American paratrooper and a Romanian soldier. The explosion also injured more than 40.

- On December 11, the Taliban conducted an attack on a hospital adjoining Bagram Airfield killing two and wounding 80 others, mostly civilians. No Coalition fatalities were reported.

Legislation, Law Enforcement, and Border Security: The Afghan Attorney General's Office investigates and prosecutes violations of the laws prohibiting membership in terrorist or insurgent groups, violent acts committed against the state, hostage taking, murder, and the use of explosives against military forces and state infrastructure. These laws were codified into one Afghan Penal Code for national security crimes on May 15, 2017, in Official Gazette \#1260. These laws include Crimes against the Internal and External Security of the State (1976 and 1987), Combat Against Terrorist Offences (2008), and Firearms, Ammunition, and Explosives (2005).

Specialized police Crisis Response Units located in the Afghan cities of Kabul, Kandahar, Mazar-e Sharif, and Herat continue to thwart and successfully respond to militant attacks.

Afghanistan continued to face significant challenges in protecting its borders, particularly those with Pakistan and Iran. Under the bilateral Afghanistan-Pakistan Action Plan for Peace and Solidarity (APAPPS), which met for the first time in July 2018, Afghan and Pakistani officials agreed in principle to create a mechanism for communication between security forces on each side of the border. On June 10 at the APAPPS Review Session in Islamabad, the Afghan and Pakistani deputy foreign ministers met to discuss trade, transit, the peace process, refugees, and closer border security coordination. Despite this review and discussions between the two governments to utilize APAPPS, progress through this forum remains slow.

Afghanistan continued to process traveler arrivals and departures at major ports of entry using U.S.-provided PISCES border security management system, which currently operates at 13 ports of entry, including the airports of Kabul, Herat, Kandahar, and Mazar-e-Sharif. The most recent implementation of PISCES was in October at the Gulum Khan border crossing of Khost province. 
Countering the Financing of Terrorism: Afghanistan is a member of the APG. In line with FATF recommendations, Afghanistan's FIU, the Financial Transactions and Reports Analysis Center of Afghanistan (FinTRACA), conducted a money laundering and terrorist-financing risk assessment in 2019. On May 15, the UN 1267 Sanctions Committee designated ISIS-K as the first ISIS affiliate to be designated by the UN.

Afghan Peace Process: Throughout 2019, the United States sought to negotiate an agreement with the Taliban that would commit the Taliban to take action against international terrorist groups, including not allowing those groups to recruit, train, or raise funds on Afghan territory, and to not host those groups. In return for these commitments and for the start of intra-Afghan negotiations that would include the Afghan government, other Afghan leaders, and the Taliban, the United States would agree to a timeline for the conditions-based withdrawal of international troops from Afghanistan. Although the United States suspended talks following Taliban attacks in early September that were inconsistent with multiple rounds of serious negotiations, these talks were restarted in December following a series of goodwill gestures by the Taliban and Afghan government, including the release of one American and one Australian hostage, the release of Taliban-held ANDSF hostages, and the release of Afghan-held Taliban prisoners.

Countering Violent Extremism: A landmark July 6-8 intra-Afghan dialogue, hosted in Doha, Qatar, and organized by Germany, brought together representatives of the Afghan government, other Afghan leaders, civil society groups (including women's groups), and the Taliban. Participating in their personal capacities, the attendees agreed on the conditions necessary to reach a sustainable peace, and a roadmap for achieving peace.

From April 28 to May 3, a Loya Jirga chaired by Mujahedin leader and Islamic scholar Abdul Rab Rassoul Sayyaf included 3,200 religious leaders, politicians, and representatives who met to discuss peace and called for an immediate ceasefire between the government and militants. The Jirga's 3,200 delegates were divided into 51 committees that developed 23 recommendations urging a cease in violence between Afghan security forces and militants. The Taliban condemned the Jirga as unrepresentative of the Afghan people.

International and Regional Cooperation: Afghanistan is a member of the Global Coalition to Defeat ISIS. In May, Afghan President Ghani agreed to participate in a trilateral meeting with Pakistan and the United States to discuss not only security but also prospective cooperation on economic growth and regional connectivity.

\section{BANGLADESH}

Overview: Bangladesh experienced a small increase in terrorist activity in 2019. ISIS claimed six IED attacks, five of which were directed at Bangladesh police. ISIS's At-Tamkin media outlet released a Bangla-language propaganda video outlining its campaign against the Bangladesh government and other declared enemies. As in prior years, the Bangladesh government denied that Bangladesh-based terrorists have meaningful ties to transnational terror groups, including ISIS or AQIS. In November, the Bangladesh government formally granted operational authority to a national Antiterrorism Unit. Also in November, the CT Special Tribunal in Dhaka sentenced seven individuals to death for their supporting roles in the 2016 
Holey Artisan Bakery attack, in which attackers claiming allegiance to ISIS killed 20 people, including one American. However, ongoing deficits in Bangladesh's judicial system contribute to a decade-long backlog of terrorism cases and a conviction rate estimated at less than 15 percent. The Bangladesh government continued to articulate a "zero tolerance" policy toward terrorism and the use of its territory as a terrorist safe haven. In December, the Bangladesh government, in concert with the U.S. Embassy, the UN, and other partners, hosted its inaugural National CVE Conference aimed at producing a national CVE strategy.

2019 Terrorist Incidents: From April to November, Bangladeshi militants detonated six IEDs. Five were directed against the Bangladesh police, while one detonated at an Awami League office in Khulna. ISIS claimed responsibility for these attacks, which caused several injuries but no deaths.

Legislation, Law Enforcement, and Border Security: In 2019, Bangladesh's criminal justice system was still in the process of fully implementing the Antiterrorism Act of 2009 as amended in 2012 and 2013. A CT Special Tribunal authorized under the Act sentenced seven men to death for their supporting roles in the 2016 Holey Artisan Bakery attack. Although Bangladesh's Antiterrorism Act does not outlaw recruitment and travel in the furtherance of terrorism, the broad language of the Act provides several mechanisms by which Bangladesh can implement UNSCR 2396 on addressing FTFs. Despite lacking laws specific to FTFs, Bangladesh arrested suspected FTFs or facilitators of such fighters on other charges under existing law.

Bangladesh cooperated with the United States to strengthen control of its borders and ports of entry. The international community remains concerned about security procedures at Dhaka's Hazrat Shahjalal International Airport. In February, a man attempted to hijack a passenger aircraft in flight, having smuggled what authorities reported was a fake gun onto the aircraft. There were several subsequent incidents in which passengers defeated screening protocols. U.S.-trained explosive detection K9 teams are available to patrol Dhaka's international airport but are not a permanent presence. Bangladesh shared law enforcement information with INTERPOL but does not have a dedicated terrorist watchlist, though the United States and Bangladesh are collaborating on the development of a national level Alert List of known or suspected terrorists. Bangladesh also does not systematically review or analyze API/PNR.

Elements of the Bangladesh Police continued a campaign of arrests and raids against suspected militants. Many suspects died in these operations, sometimes described as the result of "shootouts" or "crossfire" - often euphemisms for extrajudicial killings. Observers questioned the veracity and significance of some of the reported CT operations, describing them as either staged by law enforcement or inaccurately portrayed by the media.

In August, ISIS's At-Tamkin media outlet released a Bangla-language video directed against the Bangladesh government, as well as foreign governments, religious minorities, and other alleged enemies of Islam. In September, Dhaka Metropolitan Police's Counterterrorism and Transnational Crime Unit arrested several individuals who allegedly produced the video. 
Countering the Financing of Terrorism: Bangladesh is a member and current co-chair of the APG. The Bangladesh Financial Intelligence Unit is a member of the Egmont Group. There were no significant updates in 2019.

Countering Violent Extremism: Bangladeshi organizations continued cooperative activities through the Country Support Mechanism under GCERF, a public-private global fund to support local, grassroots CVE efforts in at-risk communities. The Ministry of Religious Affairs and the National Committee on Militancy, Resistance, and Prevention work with imams and religious scholars to build public awareness against terrorism. The police engaged religious leaders to counter terrorist propaganda with scripture-based messages and engaged imams to speak to surrendered militants to explain that the Quran does not support terrorist violence. They also continued community policing efforts. Law enforcement authorities worked with local universities to identify missing students and curb terrorist radicalization among university students. Local research institutions, including private think tanks and both public and private universities, continued to engage in CVE-related research. In December, the Counterterrorism and Transnational Crime Unit partnered with the U.S. Embassy, the UN, and various CSOs to draft a national CVE strategy for submission to the Bangladesh government.

The Bangladeshi cities of Dhaka North, Dhaka South, and Narayanganj are members of the SCN.

International and Regional Cooperation: There were no changes in 2019.

\section{INDIA}

Overview: In 2019, India suffered terrorist attacks in the state of Jammu and Kashmir, the northeastern Indian states, and parts of central India. The Government of India continued to apply sustained pressure to detect, disrupt, and degrade terrorist activities within its borders. Prime Minister Modi and other senior Indian leaders made numerous statements to condemn domestic terrorist attacks and bring to justice the perpetrators of terrorism, in cooperation with the United States and other like-minded countries.

The United States and India increased CT cooperation in 2019. In March, the United States and India held the annual Counterterrorism Joint Working Group in Washington, D.C., meeting concurrently with the second U.S.-India Designations Dialogue. Both countries announced their intent to prevent terrorists from obtaining access to weapons of mass destruction and underscored their respective commitments to the implementation of UNSCR 2396. In December, the United States hosted the 2+2 Ministerial Dialogue, in which the ministers called for concerted action against all terrorist networks, including AQ, ISIS/Daesh, LeT, JeM, HQN, Hizb-ul Mujahideen, and TTP.

\section{Terrorist Incidents:}

- On February 14, a suicide bomber from the terror group JeM, using a VBIED, killed 40 Indian soldiers from the Central Reserve Police Force in Pulwama, in the state of Jammu and Kashmir. 
- On April 9, in southern Chhattisgarh, Maoist terrorists triggered an IED, killing a Bharatiya Janata Party Chhattisgarh Legislative Assembly member and four others.

- On May 1, Maoist terrorists used landmines to kill 15 members of Maharashtra state's counter-insurgency commando unit.

- On October 29, suspected terrorists killed five migrant laborers, all from the eastern state of West Bengal, in the southern portion of the Indian state of Jammu and Kashmir.

Legislation, Law Enforcement, and Border Security: The 1967 Unlawful Activities Prevention Act was amended in August 2019 to allow for the designation of individuals as terrorists. The Indian Parliament passed amendments to the National Investigation Agency (NIA) Act of 2008 to give NIA the ability to investigate terrorism cases overseas. The newly amended NIA Act can further improve bilateral law enforcement cooperation. The efficacy and impact of the newly amended laws will likely be tested in ongoing terrorism cases in the Indian state of Jammu and Kashmir, which involve what India characterizes as "left-wing extremists," and cases involving insurgencies in Northeast India.

India's state governments continue to be responsible for law and order. India's state-level law enforcement agencies play a significant role in detecting, deterring, and preventing acts of terrorism. These state agencies have varying degrees of capability. State antiterrorism squads were created after 2008 for rapid first response.

At the central government level, NIA is the lead law enforcement investigative agency. The National Security Guard (NSG) retains the mandate for nationwide response as the sole federal contingency force. However, despite rigorous training, NSG's rapid response capability is challenged relative to India's geography and the NSG's independent logistics capacity. In addition, the NSG may not testify in judicial proceedings.

Indian security agencies are effective in disrupting terror threats despite some gaps in intelligence and information sharing. In 2016, India and the United States signed an arrangement to exchange terrorism screening information, and India continues to work on implementation. Larger Indian states have established their own state-level Multi Agency Centers and provided near-real-time information on terrorism to Indian law enforcement agencies.

The U.S. government engaged with the Indian government to improve border security and information-sharing capabilities. India is in the process of improving its ability to detect and deter terrorist travel by using watchlists, implementing biographic and biometric screening capabilities at ports of entry, and expanding information sharing. Owing to resource constraints, Indian security forces have a limited capacity to conduct maritime security, although India's ability to patrol its land border improved because of better coordination between border security forces and Indian law enforcement agencies. Bilateral capacity building is ongoing with Indian government personnel. Outreach training programs are ensuring Indian border security officials are collecting and using API and PNR to help identify malafide travelers.

Indian CT forces, at the federal and state levels, were active in detecting and disrupting transnational and regional terrorist groups, such as ISIS, its local affiliate ISIS-Bangladesh, and Jamaat-ul-Mujahideen Bangladesh (JMB). Between February and June 2019, Indian security 
forces detained nine suspected JMB and ISIS-Bangladesh terrorists from sites across India. The arrested individuals were allegedly planning attacks, ranging from jailbreaks to freeing imprisoned JMB and ISIS-Bangladesh members to attacking Indian security forces in the state of Jammu and Kashmir.

Following the April 2019 Easter bombings in Sri Lanka, the NIA conducted searches in Tamil Nadu and Kerala to investigate a suspected ISIS cell. One person was arrested in Palakkad, Kerala, on April 29 and admitted he was planning a suicide attack in Kerala.

Countering the Financing of Terrorism: India is a member of the FATF and of two FATFstyle regional bodies: the Eurasian Group on Combating Money Laundering and Financing of Terrorism (EAG) and APG. India's FIU is a member of the Egmont Group. There were no significant updates in 2019.

Countering Violent Extremism: In 2019, four Indian states (Andhra Pradesh, Kerala, Maharashtra, and Telangana) formulated CVE strategies. Indian programs continued to target disaffected sectors of Indian society that were at the highest risk of vulnerability for terrorist radicalization and recruitment. Indian government officials remain concerned about the use of the internet for terrorist purposes - including social media and messaging apps such as WhatsApp - as well as for fomenting inter-religious tension. India's law enforcement officers discussed emerging threats and steps to prevent online terrorist recruitment and radicalization with representatives from global social media companies on a regular basis. Indian officials reported online terrorist radicalization in conflict-free zones, particularly in southern Indian states, throughout the year. India's approach focused heavily on content removal and even shutting down internet access in certain regions. Mumbai remains the only Indian participant in the SCN.

International and Regional Cooperation: India is a founding member of the GCTF and participated in the GCTF, the ASEAN Regional Forum, and other UN fora on counterterrorism in 2019. India continued to use multilateral fora and bilateral visits to highlight terrorism concerns and impacts. India also continued to lead efforts to condemn terrorism and urge tangible steps against the threat in meetings of ASEAN. In November, India hosted the first Counterterrorism Table-top Exercise in the Quad country format (the United States, Australia, India, and Japan). U.S. Special Forces continued an annual exercise in Washington State alongside Indian Special Forces, which focused on CT operations in an urban environment, and also conducted a Joint Combined Exercise Training with the NSG in Hyderabad.

\section{KAZAKHSTAN}

Overview: Kazakhstan remained on guard against the potential for attacks by FTFs returning from war zones in the Middle East and Afghanistan, as well as homegrown terrorist attacks. Between January and June, the government repatriated 595 Kazakhstani FTFs and family members from Syria, prosecuting those suspected of participation in terrorist activity abroad and providing rehabilitation and reintegration services to the remainder. The government continued to implement its five-year (2018-2022) program against "religious extremism and terrorism;" 
however, the strategy's continued restrictions on religious practice have prompted concerns among some outside experts that the government's efforts may be counterproductive.

2019 Terrorist Incidents: There were no reported terrorist incidents in Kazakhstan in 2019.

Legislation, Law Enforcement, and Border Security: Kazakhstan has a comprehensive CT legal framework. The country's lead agency for counterterrorism is the Committee for National Security (KNB), which coordinates efforts among multiple state agencies and at the local level. In 2018, the government approved an ambitious five-year, \$900 million program to counter "religious extremism and terrorism." Law enforcement officers and prosecutors continued to have wide discretion to determine what qualifies as "terrorism" or "extremism," leaving political opponents and promoters of unsanctioned religious groups vulnerable to prosecution.

Kazakhstani law bans citizens from fighting in foreign wars. In 2017, the president signed a law that allows the government to deprive Kazakhstanis of citizenship if they are convicted of a range of "grave terrorism and extremism-related crimes." The government has not yet deprived anyone of citizenship in connection with such cases. The government takes a two-pronged approach to citizens returning from Iraq and Syria, offering rehabilitation services to some and arresting and prosecuting others. Between January and June, Kazakhstan carried out "Operation Zhusan," which repatriated 595 Kazakhstani citizens from Syria, including 33 male FTFs. In November, the government facilitated the return of 14 Kazakhstani children from Iraq, where their mothers were serving sentences on terrorism-related charges. The same month, KNB publicly estimated that more than 90 Kazakhstani citizens remained in Syria, in addition to six women imprisoned in Iraq.

Law enforcement units demonstrated a strong capacity to detect, deter, and respond to terrorist incidents. The government's CT plan allowed for enhanced interagency cooperation, coordination, and information sharing, but the extent to which this occurred remained unknown.

In January, KNB reported the arrest of Tajik citizens accused of planning a terrorist attack in Almaty; in September, seven individuals received prison terms ranging from 12 to 18 years in connection with the plot. In June, the Penitentiary Committee reported that approximately 600 people were serving sentences for terrorism and "extremism." Courts continued to deliver harsh sentences for the promotion of "extremism" online. For example, in August an Almaty court sentenced eight men to prison terms ranging from five to eight years on charges of promoting terrorism and religious hatred for sharing religious content that the government considered inflammatory in a WhatsApp group. In many cases, the nature of such charges is difficult to verify and, in some cases, appeared to be connected to political opposition activity. Local researchers estimate that as many as 90 percent of charges filed under laws against terrorism and "extremism" do not involve violent acts or planned violent acts.

Kazakhstan's Border Guard Service (BGS), part of the KNB, uses specialized passport control equipment, allowing officers to check for fraudulent documents. Through the first 10 months of 2019, BGS officers detected approximately three dozen cases of foreign travelers attempting to enter or transit Kazakhstan with fake documents, such as two Iranian women with fraudulent Italian passports detained at Almaty airport in October. In recent years, Kazakhstan has 
strengthened security on its southern border by adding radar systems, inspection equipment and vehicles, and specialized mobile inspection groups. The government proactively worked to prevent Kazakhstanis from traveling to fight abroad in Syria and Iraq in keeping with UNSCR 2178.

Countering the Financing of Terrorism: Kazakhstan belongs to the EAG. The Crime Statistics Committee of the Prosecutor General's Office reported that three terrorist financing cases were transferred to the court system during the first 10 months of 2019.

Countering Violent Extremism: Kazakhstan's five-year strategy places a heavy emphasis on law enforcement. The strategy focuses on teaching government sanctioned versions of Islam to youth and providing alternatives to "radicalism" through social programs and economic opportunities. The government's Committee on Religious Affairs conducted direct outreach in communities across the country. The government continued to implement rehabilitation and reintegration programs for individuals convicted of "extremism"-related offenses and their relatives. To assist with the rehabilitation and reintegration of Kazakhstani women and children repatriated from Syria, the government established 17 centers throughout the country to provide mental health services, religious instruction, and other services.

The Government of Kazakhstan censored online content to reduce "extremist" messaging. Religious experts associated with government institutions created groups on social networks, where they posted information and answered user questions about "religious extremism." Committee on Religious Affairs officials provided training for local imams, NGOs, and the media. On December 10-11, the government hosted a regional SCN workshop in Almaty on terrorist rehabilitation and reintegration.

International and Regional Cooperation: Kazakhstani agencies partnered with the United States and international organizations such as UNDP, UNODC, and the OSCE on a variety of $\mathrm{CVE}$ and terrorist travel prevention projects. As a member of the $\mathrm{C} 5+1$ diplomatic platform, Kazakhstan participates in the associated C5+1 Security Working Group, which focuses on regional CT cooperation. In December 2019, KNB agreed to work with the United States to establish a National Intelligence Fusion Cell in Nur-Sultan. With U.S. training and equipment assistance, the cell will consolidate intelligence from the Ministry of Defense, BGS, KNB, and international sources to enhance regional CT efforts. Kazakhstan also hosted a UNODCadministered regional workshop on detection and prevention of terrorist travel in Almaty in April 2019. Kazakhstan also participates in CT-related exercises and training through membership in the Collective Security Treaty Organization, the Commonwealth of Independent States (CIS), and the Shanghai Cooperation Organization.

During the 2019 CIS Summit, Kazakhstan signed a cooperative agreement between the CIS members to jointly combat terrorism, including preventive measures for "countering extremism, radicalization of the population," financing terrorism, as well as involving civil society and mass media, holding special trainings, and the use of modern technologies for timely response to potential threats. 


\section{KYRGYZ REPUBLIC}

Overview: The Kyrgyz Republic's CT efforts continue to focus on rooting out "extremists," CVE, limiting the flow of Kyrgyz FTFs, and preventing those returning from conflicts abroad from engaging in terrorist activities. While the Kyrgyz Republic is concerned about ISIS, ISIS$\mathrm{K}$, and other terrorist groups, including from Afghanistan, it has not contributed to Defeat-ISIS Coalition efforts or U.S. CT operations, due in part to a lack of resources. Terrorist attacks in the country remain rare, but the August 2016 suicide bombing against the Chinese Embassy in Bishkek and continued reports of terrorism-related arrests in 2019 - primarily FTFs returning from conflict zones - underscore the potential threat facing the country. The Kyrgyz government restricts public information on national security issues, making it very difficult to assess the efficacy of its CT operations and the true extent of the threat. The country remains vulnerable to transnational threats, especially in the remote South, where ill-defined and porous borders allow for the relatively free movement of people and illicit goods in and out of the country. According to government statistics, approximately 850 Kyrgyz citizens have left the country to join ISIS or other terrorist groups. Most experts believe the true number is higher. The Kyrgyz government faces limitations on its ability to prosecute and rehabilitate returning FTFs due to a lack of expertise, resources, and potential shortcomings in the legal framework. The country has seen the return of approximately 300 FTFs and family members.

2019 Terrorist Incidents: There were no reported terrorist incidents in the Kyrgyz Republic in 2019.

Legislation, Law Enforcement, and Border Security: As a part of ongoing criminal justice reform, the new criminal code entered into force on January 1, which decreased criminal penalties for several terrorism-related crimes. The updated law governing "extremist materials" now requires that law enforcement agencies demonstrate an intent to distribute "extremist materials" to justify the arrest of a suspect. Prior to the changes to the law, police were authorized to arrest suspects based on simple possession. Arrests have dropped sharply, and local media reported a total of only six prosecutions under the new law. There were no reports in 2019 of the government using CT laws to prosecute political opponents.

In 2018, the government reportedly installed three sets of electronic gates at the Manas Airport in Bishkek and two at the Osh airport for verification of biometric passports of Kyrgyz citizens. There is no information indicating that the government is utilizing these e-gates to scan passengers against a terrorist watchlist. The government has expressed interest in acquiring an API/PNR system for commercial flights, but this initiative would require significant donor support. International organizations and host country contacts have expressed concerns that the Prosecutor General's Office and State Committee for National Security (GKNB) lack the adequate tools or legal framework to properly prosecute citizens suspected of committing terrorist acts abroad. There were no other changes to border security since 2018.

Authorities continued to report a slow but steady stream of terrorism-related arrests in 2019, many of which involved Kyrgyz and foreign citizens who reportedly fought in Syria. According to media reports, there are 44 people currently in prison after returning from fighting in Syria. 
During the year, security services reportedly arrested several FTFs upon their return from Syria as they attempted to cross the border. These suspects reportedly planned to receive instructions on the organization of terrorist activities in Kyrgyz or in the Commonwealth of Independent States region. In October, the GKNB reported to the Kyrgyz parliament that 16 people involved in terrorist organizations had been detained - 11 on terrorism charges and five for "religious extremism." The GKNB reported that, during the first nine months of the year, the government seized 399 pieces of "extremist materials" but, due to the recent changes to the "extremism" law, did not initiate criminal cases. In November, local media reported that authorities uncovered an ISIS sleeper cell established by a Kyrgyz citizen who was recruiting compatriots to carry out terrorist attacks in the Kyrgyz Republic.

In September, the U.S. Departments of State and Homeland Security, as well as ODNI, conducted a joint review of the Kyrgyz Republic's compliance with U.S. identity-management protocols and information sharing procedures as outlined in Executive Order 13780 and Presidential Proclamation 9645. The review identified a number of key areas that did not sufficiently meet the outlined standards, including lack of a documented process for regularly and proactively providing information to the U.S. government about Known or Suspected Terrorists (KSTs); failure to issue electronic passports for Ordinary/Regular and for other major classes of passport, such as Diplomatic, Official, and Service passports; and failure to report lost and stolen travel documents to INTERPOL on an average of at least once a month (every 30 days), among other shortcomings.

Countering the Financing of Terrorism: The Kyrgyz Republic is a member of the EAG. There were no significant changes to the Kyrgyz government's efforts and capacity related to CFT in 2019. In 2019, the FIU lodged 169 money laundering reports and 118 terrorism financing reports and sent 558 financial investigative requests to relevant law enforcement bodies.

Countering Violent Extremism: The Kyrgyz government's national program and action plan on countering terrorism was in its second year of implementation in 2019. Approval of the program and action plan was considered a positive first step in establishing a coordinated national strategy, but as year two comes to a close, the government has done little to counter terrorist radicalization and recruitment. Civil society has routinely expressed concerns that the government is using the national program and action plan to muzzle free speech and to stigmatize ethnic minorities.

The Ministry of Education, in cooperation with the State Commission for Religious Affairs (SCRA), started implementing a new curriculum for high school-aged students on "moderate" Islam and identifying terrorist recruitment tactics. The Ministry of Interior and the SCRA, often in cooperation with local religious leaders and civil society, continue to host CVE roundtables and seminars and produce public awareness and counter-messaging material distributed across a range of media platforms, with much of the focus on preventing radicalization among youth and women. The Prosecutor General's Office reported in October that the Kyrgyz courts, in coordination with security agencies, blocked at least 64 websites and 233 social media accounts that were spreading "extremist material," though a local NGO reported the government has blocked 359 websites, including relatively large domains. The Kyrgyz government cooperates 
with the UN, OSCE and other international organizations and foreign governments to facilitate CVE training and other CVE-related assistance programs.

UNODC continues to support the Kyrgyz Prison Service in the development of strategies to manage the spread of extremism among prisoners and prevent radicalization, in line with international norms. The UNODC is now implementing a program to prepare the Kyrgyz prison service for the eventual return of FTFs. The program will include training, security upgrades, and the implementation of internationally recognized best practices for the incarceration of terrorists.

International and Regional Cooperation: In 2019, the Kyrgyz Republic participated in a variety of CT activities and trainings organized by the U.S. government, UNODC, the OSCE, Collective Security Treaty Organization (CSTO), CIS, and SCO. The Kyrgyz military allocated the vast majority of its CT training resources to exercises dominated by Russia. The Kyrgyz Republic participated in seven international CT training events for military or law enforcement in 2019. These exercises included bilateral CT training exercises with Russia, India,

Kazakhstan, and - for the first time ever for the Kyrgyz Republic - China. During the 2019 CIS Summit, the Kyrgyz president signed a cooperative agreement between CIS members to jointly combat terrorism, including through preventive measures for "countering extremism, radicalization of the population," and financing terrorism, as well as involving civil society and mass media, holding special trainings, and the use of modern technologies for timely response to potential threats.

\section{MALDIVES}

Overview: In 2019, the Government of Maldives's CT efforts concentrated on CVE and limiting the flow of FTFs. Those within the penal system or involved in criminal gangs are at a heightened risk of terrorist radicalization. The government claims that 188 cases related to "religious extremism" were reported between January 1, 2014, and October 31, 2019. Of these, 14 were brought forward for prosecution.

In October, Maldivian police arrested ISIS-K recruiter Mohamad Ameen on "suspicion of spreading extremist ideology." Ameen recruited for ISIS in Syria, Afghanistan, and Maldives. Media reports also alleged that Ameen was suspected of involvement in the September 2007 Sultan Park bombing in Malé.

In October, Maldives passed an amendment strengthening its 2015 Anti-Terrorism Act. The amendment clarified the definition of terrorism, expanded the number of chargeable offenses related to terrorism, and introduced a monitoring mechanism to prevent politically motivated prosecutions.

2019 Terrorist Incidents: There were no reported terrorist incidents in Maldives in 2019.

Legislation, Law Enforcement, and Border Security: The Anti-Terrorism Act is the primary legislation for preventing and prosecuting terrorism. In October, the government passed an amendment strengthening the ATA. This amendment authorizes the Maldives Police Service 
(MPS) to make warrantless arrests for criminal acts defined as terrorism; criminalizes supporting "extremist" ideologies, departing for a war zone without government authorization, assisting individuals attempting to join militant groups, and withholding information regarding terrorism from authorities; and introduces longer prison sentences for terrorism. The amendment requires the establishment of a rehabilitation and reintegration center for returning Maldivian FTFs, including a separate space for women and children deemed victims who did not commit acts of terrorism. The law also creates a new CT risk assessment committee to assess whether repatriated individuals engaged in acts of terrorism or might be inclined to do so in the future. Parliament was given oversight authority through a monitoring mechanism in the amendment to prevent politically motivated prosecutions such as those that occurred in 2018 and previously.

In September, the government designated 17 terrorist organizations under the ATA, criminalizing participation in, or support to, such organizations.

In September, the Presidential Commission on Deaths and Enforced Disappearances released its findings regarding the 2014 disappearance of Maldivian journalist Ahmed Rilwan, concluding he was abducted and killed by a Maldivian terrorist group linked to al-Qa'ida. The commission asked the Prosecutor General's Office (PGO) to appeal the acquittal of two suspects accused of involvement in the killing and determine whether there is sufficient evidence to prosecute additional individuals suspected of involvement.

In November 2018, the Criminal Court ordered the conditional release of two Maldivians charged in November 2017 with conspiring with ISIS to launch a suicide attack in Malé, based on their treatment during detention. The Maldivian High Court reversed this decision in April and ordered the two individuals detained for the duration of their trials.

The MPS is responsible for CT investigations. It transfers cases to the PGO for the duration of trials. Responsibility for CT operations, including investigations, primarily rests with MPS. The Maldives National Defense Force (MNDF), including the marines and coast guard, are responsible for CT response. The MNDF conducts routine Subject Matter Expert Exchanges and Joint Combined Exercise and Training engagements with U.S. forces focused on CT operations. The engagements also enhance maritime security capabilities to increase Maldives domain awareness and security. Maldives and the United States partnered in 2019 to upgrade the U.S.provided PISCES integrated border management system. Information sharing on potential security threats between Maldivian security agencies has improved but remains a challenge.

Countering the Financing of Terrorism: Maldives is a member of the APG. There were no significant updates in 2019.

Countering Violent Extremism: In July, President Solih announced Maldives' intent to facilitate the return and prosecution of Maldivian FTFs and families in Syria. According to MPS Commissioner Hameed's December 16 public remarks, there are approximately 1,400 "religious extremists" located in the Maldives. The Maldives' National Counter Terrorism Center (NCTC) held numerous regional workshops and capacity building exercises with both public and private sector groups, to include counter-narrative creation, the role of educators in countering "extremism," and aviation security. In October, President Solih announced a five-year CVE 
strategic action plan, designating the NCTC as the national coordination body for these efforts. Male is a member of the SCN.

International and Regional Cooperation: Government officials participated in and jointly hosted multiple international and regional workshops on CT efforts. In February 2019, a joint report was issued by the NCTC, UNDP, and Government of Japan on youth vulnerability in the Maldives. This report highlighted concerns over the increasing use of religion as a political weapon and the increasing influence of Salafism. It also highlighted concern about the number of foreign preachers present in the Maldives and their role in recruitment for terrorist organizations. In October, CTED conducted a visit to examine issues relating to CVE. The NCTC, in conjunction with CTED, hosted a three-day regional workshop on obtaining electronic evidence in CT investigations. Additionally, in October, the government concluded an agreement with the Government of Japan for \$4.6 million in Japanese aid to bolster CT efforts.

NEPAL

Overview: Nepal experienced no acts of international terrorism in 2019. Political violence in Nepal remained small in scale and involved attacks on large-scale infrastructure, government offices, or locations affiliated with political parties or officials. Violence occurring on or around the 2019 by-elections focused on voter intimidation and, in some cases, political extortion. The Government of Nepal attributed the majority of the attacks to the Communist Party of Nepal (CPN), a political faction better known as "Biplav," led by Netra Bikram Chand. The CPN split from the former Communist Party of Nepal (Maoist Center) in 2015. Nepal's security services continue to monitor the Biplav Group, an insurgent group that sometimes engages in terrorism to attempt to achieve its goals. Due to the open border with India and insufficient security protocols at the country's sole international airport in Kathmandu, Nepal could be used as a transit or staging point for international terrorists.

2019 Terrorist Incidents: Domestic incidents included small bombings in various locations throughout the country, for which authorities blamed the Biplav Group. The attacks employed small, real, or hoax IEDs. In total, Embassy Kathmandu, with assistance from Nepali law enforcement contacts, attributed an estimated 34 IEDs, 5 hoaxes, and 29 arson attacks to Biplav in 2019.

- On February 22, a series of 15 IED or arson attacks on cell phone towers owned by telecommunications service provider Ncell took place across Nepal, killing one person and injuring two others.

- Throughout the year, Biplav organized numerous nation-wide protests, which were frequently accompanied by IED attacks and other forms of violence. One notable protest began on May 27 and lasted two days. The protests resulted in a series of three IED explosions targeting government offices and Nepal Communist Party (NCP, not to be confused with the Community Party of Nepal) headquarters in Kathmandu, killing four and injuring seven. The Home Ministry announced that 15 Biplav members had been arrested in connection with the May 27 and 28 explosions. 
- On July 30-31 Biplav again targeted Ncell, carrying out a number of arson and IED attacks in the central region of Nepal as part of a nation-wide protest. The attacks destroyed 22 cell towers.

- During the by-elections on November 30, there were approximately nine instances of IEDs, including one hoax, primarily targeting polling station locations. It is widely assessed that the attacks were intended to intimidate political candidates, convince voters to stay home, and undermine the elections.

- Most recently, on December 14 an IED exploded in Dhanusha, killing three people and injuring four.

Legislation, Law Enforcement, and Border Security: There were no changes in Nepal in 2019.

Countering the Financing of Terrorism: Nepal is a member of the APG. There were no significant updates in 2019.

Countering Violent Extremism: Nepal does not employ strategic communications to counter terrorist radicalization and recruitment. There are no government or civil society programs in Nepal to counter terrorist recruitment or rehabilitate former terrorists. The government generally does not view terrorism, specifically "extremist" ideology originating from conflict or instability in the Middle East, as a significant threat in Nepal. Nepal appears to be largely infertile soil for terrorism propagated by international terrorist organizations. A more significant threat is nonNepali international terrorist groups using Nepal as a transit or staging point or soft target.

International and Regional Cooperation: Nepal is a signatory of the South Asian Association for Regional Cooperation Regional Convention on Suppression of Terrorism. INTERPOL hosts an annual regional CT seminar to which the Nepal Police sends two to three officers.

\section{PAKISTAN}

Overview: Pakistan continued to serve as a safe haven for certain regionally focused terrorist groups. It allowed groups targeting Afghanistan, including the Afghan Taliban and affiliated HQN, as well as groups targeting India, including LeT and its affiliated front organizations, and JeM, to operate from its territory.

Pakistan took modest steps in 2019 to counter terror financing and to restrain some India-focused militant groups following the February attack on a security convoy in the Indian state of Jammu and Kashmir claimed by Pakistan-based JeM. Thus far, however, Islamabad has yet to take actions against Indian- and Afghanistan-focused militants who would undermine their operational capability. The Pakistani government also played a constructive role in U.S.-Taliban talks in 2019. Pakistan's progress on the most difficult aspects of its 2015 National Action Plan to counter terrorism remains unfulfilled - specifically its pledge to dismantle all terrorist organizations without delay and discrimination. While Pakistani authorities indicted LeT cofounder Hafiz Saeed and 12 of his associates on December 11, they have made no effort to use domestic authorities to prosecute other known terrorist leaders. These include JeM founder Masood Azhar and Sajid Mir, the mastermind of LeT's 2008 Mumbai attacks, both of whom are 
widely believed to reside in Pakistan under the protection of the state, despite government denials.

Pakistan experienced significant terrorist threats in 2019, although the number of attacks and casualties was lower than in 2018, continuing an overall year-on-year decline. Major terrorist groups focused on conducting attacks in Pakistan included Tehrik-e-Taliban Pakistan (TTP or Pakistani Taliban) and ISIS-K. Separatist militant groups conducted terrorist attacks against varied targets in Balochistan and Sindh provinces. Terrorists used a range of tactics to attack individuals, markets, police checkpoints, and places of worship, including IEDs, VBIEDs, suicide bombings, and targeted assassinations.

In June 2018, the FATF placed Pakistan on its "gray list" and issued an Action Plan directing Pakistan to take specific steps by September 2019 to address strategic deficiencies in its CFT efforts. The FATF expressed serious concern at its October 2019 plenary about Pakistan's continued deficiencies but noted it had made some progress and extended the deadline for full Action Plan implementation to February 2020.

In 2018, Pakistan was designated as a "Country of Particular Concern" (CPC) under the International Religious Freedom Act of 1998. It was re-designated as a CPC in 2019.

2019 Terrorist Incidents: Pakistan experienced numerous terrorist attacks in 2019. The following examples include some of the more destructive and high-profile attacks and demonstrate a variety of methods, targets, and perpetrators:

- On May 8, a suicide bomber killed at least 10 (including police officers and security guards) and wounded at least 24 others in an attack at Lahore's Data Darbar Sufi shrine. Hizbul Ahrar, a faction of TTP, claimed responsibility for the attack, specifying that the target was law enforcement officers and not civilians.

- On May 11, three militants killed five (including a Pakistani Navy officer) and injured six in an attack on the Pearl Continental Hotel in Gwadar. The Balochistan Liberation Army claimed responsibility for the attack, stating the targets were Chinese and other foreign investors.

- On July 21, two back-to-back attacks in Dera Ismail Khan, Khyber-Pakhtunkhwa, killed 10 and injured 30. Unidentified gunmen on motorbikes opened fire on a police checkpoint killing two police officers. A suicide bomber later detonated an explosive device at the hospital where first responders transported victims of the first attack. TTP claimed responsibility for the attack.

- On August 16, a timed explosive at Quetta's Al-Haj mosque detonated, killing four (including the brother of Afghan Taliban chief Mullah Haybatullah) and injuring 25 others. No group has claimed responsibility for the attack.

Legislation, Law Enforcement, and Border Security: The Pakistani government continued to implement the Antiterrorism Act of 1997, the National Counterterrorism Authority (NACTA) Act, the 2014 Investigation for Fair Trial Act, and 2014 amendments to the Antiterrorism Act (ATA), all of which give law enforcement, prosecutors, and courts enhanced powers in terrorism cases. 
Military, paramilitary, and civilian security forces conducted CT operations throughout Pakistan against anti-state militants. Pakistani law allows for preventive detention, permits the death penalty for terrorism offenses, and authorizes special Anti-Terrorism Courts to try terrorism cases. Military courts established in 2015 under the National Action Plan to try civilians accused of terrorism ceased operation March 31.

Pakistan collects biometric information at land crossings through its International Border Management Security System. Authorities had limited ability to detect smuggling by air travel. The Customs Service attempted to enforce anti-money laundering laws and foreign exchange regulations at all major airports, in coordination with other agencies. Customs managed the entry of dual-use chemicals for legitimate purposes through end-use verification, while also attempting to prevent their diversion for use in IEDs. Consistent with UNSCR 2178, returning FTFs may be prosecuted under Pakistani law. NACTA is responsible for compiling and verifying data on these individuals.

Countering the Financing of Terrorism: Pakistan is a member of the APG. Since June 2018, FATF has identified Pakistan as a jurisdiction with strategic deficiencies in its CFT system. In 2019, Pakistan made some progress toward meeting the action plan requirements for the FATF, allowing it to avoid being blacklisted, but did not complete all action plan items. In early 2019, Pakistan issued, inter alia, a statutory regulatory ordinance directing immediate implementation of sanctions against individuals and entities designated under UNSCR 1267. In October 2019, APG published a Mutual Evaluation Report that reviewed Pakistan's compliance with FATF standards and the effectiveness of Pakistan's AML/CFT system.

Countering Violent Extremism: The government operated five de-radicalization camps offering "corrective religious education," vocational training, counseling, and therapy. A Pakistani NGO administered the juvenile-focused Sabaoon Rehabilitation Center in Swat Valley, which it founded in partnership with the Pakistani military.

Some madrassas reportedly continued to teach "extremist" doctrine. The National Action Plan directs increased government supervision of madrassas, and there was evidence of continued government efforts to increase regulation. Security analysts and madrassa reform proponents observed, however, that many madrassas failed to register with the government or provide documentation of their sources of funding or to limit their acceptance of foreign students to those with valid visas, a background check, and the consent of their governments, as required by law.

The Pakistani cities of Nowshera, Peshawar, and Quetta are members of the SCN.

International and Regional Cooperation: Pakistan participated in several multilateral fora where CT cooperation was discussed, including the GCTF, the Heart of Asia-Istanbul Process, and the ASEAN Regional Forum. Pakistan has been slated to host the next summit of the South Asian Association for Regional Cooperation (SAARC) and the first since 2016, when all other SAARC member states boycotted the planned Islamabad summit following terrorist attacks on Indian security personnel committed by Pakistani groups. 
SRI LANKA

Overview: ISIS-inspired terrorists conducted a series of suicide attacks against churches and hotels across Sri Lanka on Easter Day, resulting in hundreds of casualties. Then ISIS leader Abu Bakr al-Baghdadi publicly praised the attacks, illustrating that ISIS remains determined, following its defeat in Syria and Iraq, to continue the fight from its global branches and networks and by inspiring attacks. The attacks led to isolated outbreaks of anti-Muslim violence, which the government made efforts to stop, though some observers deemed these efforts insufficient. Sri Lanka also conducted prosecutions against members of the Liberation Tigers of Tamil Eelam (LTTE), a terrorist insurgent group that fought the government for 26 years until its defeat in 2009.

Following the Easter attacks, Sri Lanka sought to improve its CT efforts by engaging the United States on improving border security and soliciting assistance for the Attorney General's office, which is charged with prosecuting the attack perpetrators. Sri Lanka is not a member of the Global Coalition to Defeat ISIS, but participated as an observer at the Political Directors meeting in June. The country's secretary of defense and inspector general of police at the time of the April 21 attacks were both arrested for failing to act on available intelligence, which warned of pending attacks.

\section{Terrorist Incidents:}

- On Easter Sunday, Sri Lankan citizens who pledged allegiance to ISIS detonated backpack suicide bombs in four hotels and three churches in the greater Colombo area and Batticaloa, killing more than 260 people, including five Americans.

Legislation, Law Enforcement, and Border Security: The Government of Sri Lanka continued to use the Prevention of Terrorism Act (PTA), enacted in 1979 as a wartime measure, which gives the police broad powers to search, arrest, and detain individuals. After the Easter attacks, the government issued a four-month state of emergency, which also gave search, detain, and arrest powers to the military. More than 1,000 individuals were arrested under the PTA in wake of the attacks, although just more than 100 remained in custody at year's end. A draft Counter Terrorism Act (CTA) set to repeal and replace the PTA remained under debate in parliament at year's end. According to international and domestic legal experts, the CTA would clarify the definition and punishment for terrorist activities and provide a current schedule of designated terrorist organizations. The first version of the schedule designated three domestic terrorist organizations, all of which had been connected to the Easter attacks. In August, parliament passed the "Mutual Assistance in Criminal Matters (Amendment) Act, No. 24 of 2018 (MACMA)," which made a number of improvements to Sri Lanka's processing of mutual legal assistance requests, which could help in prosecuting terrorism cases.

The Special Task Force is a paramilitary unit of the Sri Lanka Police specializing in CT and counterinsurgency operations and charged with ensuring security of top government and foreign government officials, protecting sensitive targets, and suppressing activities that pose a threat to national security. Within the regular police structure, there is a Counter-Terrorism Investigation 
Division, which was moved under the Criminal Investigation Division in May. The police remained under the Ministry of Defense at year's end. The Easter attacks highlighted gaps in information sharing among Sri Lanka's security sector agencies. Reforms to address these issues were underway at year's end. Sri Lanka Police cooperated extensively with the FBI on the investigation into the Easter attacks. All suspects related to these attacks are currently in custody. Indictments for these attacks were pending at year's end.

Sri Lanka's border and maritime security remained vulnerable. The government is working with the UN, along with Japan, to enhance border management systems at Colombo's international airport. The Sri Lankan government also expanded its partnership with the United States to secure its maritime border. The U.S. Coast Guard, under the Department of State's EXBS (Export Control and Related Border Security) program, continued to train Sri Lankan Coast Guard and Navy personnel on maritime law enforcement and security operation, and the Government of Sri Lanka continued to cooperate with U.S. Customs and Border Protection and the Department of Energy through the container security initiative, "Megaports Initiative." The U.S. Department of Defense continues regular engagements with the Sri Lankan Navy Special Boat Squadron and Fast Attack Flotilla to enhance maritime security through the expansion of vessel board, search, and seizure capabilities.

Sri Lanka concluded two major trials of terrorist attacks from the LTTE period. On January 10, the North Central Provincial High Court sentenced two former LTTE members to 185 years' rigorous imprisonment for shooting down a Sri Lankan Air Force plane in March 2000, which killed 37 people. On January 23, the Anuradhapura High Court sentenced two former LTTE members to 25 years' rigorous imprisonment for the murder of eight people, including an Army officer, in 2007. Throughout the year, police arrested several people who are alleged to have had ties to the LTTE for possession of weapons and ammunition.

Countering the Financing of Terrorism: Sri Lanka belongs to APG, a FATF-style regional body. Sri Lanka's FIU is a member of the Egmont Group. In October, FATF removed Sri Lanka from its grey list after Sri Lanka completed an action plan to address the strategic deficiencies in its AML/CFT system.

Countering Violent Extremism: Following the April attacks, the Sri Lankan government established a new office under the Ministry of Defense to create new CVE policies to counter violent extremism. Discussions of education reforms and other measures were underway at year's end.

International and Regional Cooperation: Sri Lanka has actively sought assistance on CT issues from the United Nations after the attacks, as well as from key donor countries. The EU, the United Kingdom, Australia, Japan, and India have all pledged CT assistance - with India offering \$50 million to the newly-elected Rajapaksa administration. Sri Lanka is a partner nation in the Global Initiative to Combat Nuclear Terrorism. 


\section{TAJIKISTAN}

Overview: The Tajik government continues to make efforts to improve the capacity of law enforcement agencies to combat terrorism, enhance border security, and detect terrorist financing. The government maintains that northern Afghanistan is a primary source of terrorist activity, and Tajik security officials allege that thousands of militants, including FTFs, are present in Afghanistan's northern provinces. The Tajik government reported on May 19 that prison guards and inmates were killed in a riot that broke out at the Kirpichniy high-security correctional facility on the outskirts of Dushanbe. On November 6, ISIS claimed responsibility for an attack on a remote border post along the Tajik-Uzbek border. The Tajik government cooperates with international organizations, such as the EU, the OSCE, and UN on combating terrorism. Tajikistan is willing to engage with the United States on CT and border security issues.

\section{Terrorist Incidents:}

- On May 19 the Tajik government reported that three prison guards and 29 inmates were killed in a riot that broke out at the Kirpichniy high-security correctional facility in Vahdat on the outskirts of Dushanbe. Tajik authorities blamed the uprising on inmates serving time for alleged ties to terrorist or "extremist" groups. The Tajik Ministry of Interior Affairs also claimed that the ringleader of the riot was Behruz Gulmurod, the son of Gulmurod Halimov, the former Tajik special forces commander who defected to ISIS in 2015. ISIS claimed responsibility for the riot, as well as the release of prisoners affiliated with the Islamic State.

- On November 6, ISIS claimed responsibility for an attack on a remote border post along the Tajik-Uzbek border that Tajik authorities claim killed at least 17 people. The State Committee for National Security (GKNB) affirmed that the attackers were ISIS loyalists and that the attack occurred near the small town of Esanboi, in Tajikistan's southwest Rudaki region.

Legislation, Law Enforcement, and Border Security: Tajikistan's lower house of Parliament ratified an agreement in October that authorized border agencies of Commonwealth of Independent States to assist with rapid response to external border threats. OSCE's Transnational Threats Department convened a CT seminar in Dushanbe that provided Tajik law enforcement officials with a platform to share best practices for criminal justice responses for combatting terrorism. Tajikistan repatriated 84 children of FTFs using its own resources in April. The Tajik government continues to unilaterally designate political opposition groups such as the Islamic Renaissance Party of Tajikistan, or religious affiliations, such as Salafi Muslims, as terrorist groups.

Travel document security and biographic and biometric screening capabilities are still lacking at ports of entry, particularly at land crossings. Major entry points have access to INTERPOL data and other lists, but connectivity issues at smaller border posts remain unresolved. 
Countering the Financing of Terrorism: Tajikistan is a member of the EAG. Tajikistan's FIU is also a member of the Egmont Group.

In January, the EAG published a Mutual Evaluation Report that reviewed Tajikistan's compliance with FATF standards and the effectiveness of Tajikistan's AML/CFT system. In May, Tajikistan hosted the second annual high-level conference dedicated to addressing regional terrorism trends, "International and Regional Cooperation on Countering Terrorism and its Financing through Illicit Drug Trafficking and Organized Crime." High-ranking delegates from former Soviet bloc countries, Afghanistan, Japan, the United States, and multilateral organizations including the UN, the OSCE, and CSTO member states participated.

On December 1, the National Bank of Tajikistan (NBT) announced that it will launch a national money transfer center that will centralize the receipt of remittances from abroad. The NBT will be able to monitor and regulate alternative remittances services, collect data on wire transfers, and monitor non-profit organizations to prevent misuse of financing to sponsor terrorist activities.

Countering Violent Extremism: Tajikistan amended its criminal laws in 2015, allowing authorities to pardon Tajik FTFs who voluntarily return home from Iraq or Syria, express remorse for their actions, and renounce ties to foreign militant groups. The Tajik government continues to place heavy restrictions on groups it classifies as "extremist," including those groups' political and religious expression. In 2019, Tajikistan was again designated a "Country of Particular Concern" under the International Religious Freedom Act of 1998.

International and Regional Cooperation: Tajikistan is a strong supporter of the $\mathrm{C} 5+1$ framework in the region and serves as a co-chair of the C5+1 Security Working Group. In May, Tajikistan hosted the most recent Security Working Group, with the participation of the United States Institute for Peace (USIP), where participants discussed efforts to repatriate, rehabilitate, and reintegrate FTFs.

The Tajik government coordinated with the UN High Commissioner for Refugees to prepare for the potential influx of Afghan refugees and/or civil unrest in Afghanistan. Twenty-eight government agencies participated in the June exercise to prepare a government response to the potential influx of Afghan refugees in case of widespread unrest in northern Afghanistan.

The People's Liberation Army (PLA) of China arrived in Badakhshon's Ishkashim district for joint Tajik-Chinese anti-terrorism exercises in August. The joint exercises took place along the border with Afghanistan and involved one PLA company and a Tajik mobile forces battalion. The two militaries trained against terrorist infiltration from Afghanistan into China via Tajik territory.

Tajikistan also participated in UNODC-administered training on detecting and preventing terrorist travel to enhance compliance with UNSCR 2396. Tajikistan is a member of the Commonwealth of Independent States (CIS) and Shanghai Cooperation Organisation. During the 2019 CIS Summit, Tajikistan's president signed onto a cooperative agreement between the CIS members to jointly combat terrorism. The agreement included preventive measures for 
"countering extremism, radicalization of the population," and financing terrorism, as well as involving civil society and mass media, holding special trainings, and the use of modern technologies for timely response to potential threats.

\section{TURKMENISTAN}

Overview: The Government of Turkmenistan continued its efforts to improve the capacity of law enforcement agencies to combat terrorism, ensure border security, and detect terrorist financing. The government continued to cooperate with international organizations and participated in the $\mathrm{C} 5+1$ regional framework to counter international terrorism. Turkmen authorities continued to maintain close surveillance on its population and borders.

2019 Terrorist Incidents: There were no reported terrorist incidents in Turkmenistan in 2019.

Legislation, Law Enforcement, and Border Security: There were no reported changes in 2019.

Countering the Financing of Terrorism: Turkmenistan belongs to the EAG, and the government continued to express interest in gaining admission to the Egmont Group. During 2019, the Government of Turkmenistan cooperated with and attended trainings offered by international organizations such as the UN and the OSCE on responding to CT threats, combating money laundering, and other CFT issues. The Turkmen government continued to monitor and regulate alternative remittance services, collected data on wire transfers, and monitored non-profit organizations, purportedly to prevent misuse of financing to sponsor terrorist activities

Countering Violent Extremism: In 2019, the Government of Turkmenistan cooperated with international organizations and participated in the C5+1 regional CVE framework. Turkmen government officials also participated in the C5+1 regional framework, held in August in NurSultan and September in New York, to counter international terrorism. Officials also participated in a C5+1 regional workshop in Tajikistan in May, with the participation of USIP, and met with CVE experts from USIP in Ashgabat in July.

International and Regional Cooperation: Turkmenistan continued to cooperate with international and regional organizations such as the Counter-Terrorism Implementation Task Force, the UN Regional Centre for Preventive Diplomacy for Central Asia, the UNODC, the UN Counter-Terrorism Center, the EU, the OSCE, and others.

In May 2019, a delegation from Turkmenistan met with CTED leadership during the High-Level Conference on International and Regional Cooperation on Countering Terrorism in Dushanbe. During the Commonwealth of Independent States summit in Ashgabat on October 11, the heads of state adopted and signed a Program of Cooperation among the member states of the Commonwealth of Independent States in the Fight against Terrorism and Other Violent Extremism for 2020-2022. 
Consultations of CIS countries on combatting terrorism were held in Ashgabat on November 14. Participants discussed widening collective actions on combatting terrorism, the role of the UN in combatting terrorism and its financial backing, and rendering the required legal assistance among the CIS partners. The parties also discussed preventive measures for "countering extremism, radicalization of the population," and financing terrorism. They also addressed the necessity of involving civil society and mass media, holding special trainings, and the use of modern technologies for timely response to potential threats.

As a member of the C5+1 diplomatic platform, Turkmenistan participates in the associated Security Working Group, which focuses on regional CT cooperation.

\section{UZBEKISTAN}

Overview: The Government of Uzbekistan remained concerned about the potential spillover of terrorism from Afghanistan and its Central Asian neighbors, the return of ISIS fighters from Iraq and Syria, and terrorist radicalization of Uzbekistanis abroad. The government has actively worked to improve its implementation of existing laws, including the development of a comprehensive national CT strategy and action plan, but there were no changes to the legislative framework in 2019. Uzbekistan continued to improve relations with its neighbors in many areas, including security cooperation. Uzbekistan remains an active participant in the $\mathrm{C} 5+1$ diplomatic platform, which supports CVE programming. Uzbekistan also signed a bilateral agreement with India on CT cooperation and a separate agreement with CIS states in 2019.

2019 Terrorist Incidents: There were no reported terrorist incidents in Uzbekistan in 2019.

Legislation, Law Enforcement, and Border Security: There were no significant changes to terrorism-related legislation and law enforcement practices in 2019. The Law on Combating Terrorism governs terrorism-related investigations and prosecutions and identifies the State Security Service (SSS) as the lead CT law enforcement agency. The SSS and the Ministry of Internal Affairs (MIA) have dedicated CT units. Uzbekistan also criminalizes terrorism under its criminal code, and the National Development Strategy for 2017-2021 targets corruption, "extremism," and terrorism.

The government reported an additional removal of 402 people from its watchlist of alleged "extremists" in 2019. The government facilitated the return of 156 individuals mostly women and children from Iraq and Syria and continued to explore options on the potential repatriation of FTFs from Syria throughout 2019.

Uzbek law enforcement maintains its own terrorist watchlist and contributes to INTERPOL databases. Most border posts and airports are equipped with biometric data scanners. Uzbekistan has mostly completed the conversion of all passports to a new biometric version and has introduced international biometric passports for travel abroad.

Uzbekistan has not reported specific actions to implement UNSCRs 2309 and 2396. 
Countering the Financing of Terrorism: Uzbekistan belongs to the EAG. There were no updates in the passage or implementation of laws pertaining to CFT in 2019. Government officials received INL-funded training in 2019 that will support the ability to conduct financial investigations, improve interagency coordination on AML/CFT, and prepare for the upcoming EAG assessment of Uzbekistan's compliance with international FATF standards. In addition, the Commission on Combatting Money Laundering and Financing of Terrorism, headed by the Prosecutor General's Office (PGO) is preparing a new resolution to introduce joint financial investigations by MIA, SSS, PGO, and FIU.

Countering Violent Extremism: Uzbekistan remains concerned about the terrorist radicalization of Uzbekistanis, particularly labor migrants in Russia and other countries. Local government organizations continued to educate citizens about the dangers of "religious extremism." The government has developed advertisements and funded other projects specifically targeting migrants deemed to be at high risk of terrorist radicalization. Official media and Tashkent Islamic University produced public messages about the dangers of terrorism and posted them on social media platforms and messaging apps.

The Government of Uzbekistan has publicly endorsed rehabilitation and reintegration of citizens previously engaged or suspected of being engaged in terrorist activities. In 2019, the government repatriated 220 FTF family members from Iraq and Syria, mostly women and children. The government has worked to reintegrate them into their home communities and has expeditiously identified suitable family for unaccompanied minors or placed them in orphanages. In close cooperation with UNICEF, the government has provided a mix of national and locallevel social services to help reintegrate the returnees and has continuously monitored their progress.

In 2019, with support from the OSCE, an interagency working group coordinated by the Uzbekistani National Security Council developed a national strategy on "preventing and countering violent extremism and terrorism." That working group participated in a State Department-funded trip to the United States in late 2019 as part of a plan to finalize the strategy and action plan. Formal adoption of the strategy is expected in early 2020. The government also participated in the Central Asia + United States $(\mathrm{C} 5+1)$ regional CVE framework. This included the hosting of a C5+1 regional workshop on CVE in May in Tashkent and a separate event in Samarkand in November focused on FTF reintegration and rehabilitation.

International and Regional Cooperation: Uzbekistan is a member of the Organization of Islamic Cooperation. In 2019, Uzbekistan continued its participation in the UN Counter Terrorism Committee and the OSCE Action against Terrorism Unit. During the 2019 CIS Summit, Uzbekistan became a signatory to a cooperative agreement between CIS members to jointly combat terrorism. The agreement included preventive measures for "countering extremism, radicalization of the population," financing terrorism, as well as involving civil society and mass media, holding special trainings, and the use of modern technologies for timely response to potential threats. In addition, Uzbekistan has sought bilateral agreements with other countries related to CT issues and signed an agreement with India in November on enhanced CT cooperation. 
In 2019, Uzbekistan continued its active engagement in the C5+1 diplomatic platform and its associated C5+1 Security Working Group, which focuses on regional CT cooperation and participated in a Strong Cities regional workshop in Almaty in December that focused on reintegration and rehabilitation of FTFs and their families. Uzbekistan also participated in UNODC-administered training on detecting and preventing terrorist travel to enhance compliance with UNSCR 2396.

\section{WESTERN HEMISPHERE}

Overview: In 2019, the Lebanon-based and Iran-backed terrorist group Hizballah continued its long history of activity in the Western Hemisphere, including its use of supporters and financiers who operate in the Tri-Border Area (TBA) of South America, where Argentina, Brazil, and Paraguay meet. The United States continues to be vigilant about individuals affiliated with international terrorist groups, including al-Qa'ida and ISIS, who have made attempts to exploit the region. These include a suspected AQ operative in Brazil, about whom the FBI issued a public notice in August, as well as ISIS supporters and sympathizers in a number of countries including Canada and Trinidad and Tobago. Meanwhile, regional terrorist groups, such as the National Liberation Army (ELN) and Shining Path, were active in the hemisphere, including in Colombia, Venezuela, and Peru. In Colombia, an estimated 2,600 Revolutionary Armed Forces of Colombia (FARC) dissidents who never demobilized, left the peace process, or are new recruits, continued violent attacks, primarily to enable narcotics trafficking and other criminal activities. While travel of FTFs from the Western Hemisphere to conflict zones was limited in 2019 , the potential return of these battle-tested terrorists remained a concern.

Many Latin American countries have porous borders, limited law enforcement capabilities, and established smuggling routes. Commercial hubs in the TBA and Panama remained regional nodes for money laundering and vulnerable to terrorist financing. Corruption, weak government institutions, insufficient interagency cooperation, weak or non-existent legislation, and a general lack of resources likewise remained obstacles to improving security. Nevertheless, some Western Hemisphere countries made significant progress in their counterterrorism efforts in 2019 and strengthened regional cooperation against terrorism.

Cuba and Venezuela continued to provide permissive environments for terrorists. In Venezuela, individuals linked to FARC dissidents (who remain committed to terrorism notwithstanding the peace accord) and the ELN, as well as Hizballah sympathizers, were present in the country. Nicolas Maduro has openly welcomed former FARC leaders who announced a return to terrorist activities. Members of the ELN who were in Havana to conduct peace talks with the Colombian government since 2017 also remained in Cuba. Cuba, citing peace negotiation protocols, refused Colombia's request to extradite 10 ELN leaders after that group claimed responsibility for the January 2019 bombing of a Bogota police academy, which killed 22 and injured 87 others. Multiple fugitives who committed or supported acts of terrorism in the United States also continued to live freely in Cuba.

Several countries in the region took steps in 2019 to designate Hizballah as a terrorist organization. Argentina developed a new sanctions regime and used it to designate the entirety of Hizballah and individuals specifically connected to the 1992 and 1994 bombings of the Israeli 
Embassy and Argentine Israelite Mutual Association Jewish community center in Buenos Aires. Paraguay designated terrorist organizations and individuals, in particular targeting Hizballah, and is identifying possible sanctions against designated entities. In October, Venezuela's democratically elected National Assembly designated Hizballah as a terrorist organization, along with other groups including ISIS and ELN. In Peru, the government continued efforts to retry Hizballah operative Muhammad Ghaleb Hamdar after a Peruvian court previously acquitted him of terrorism charges in 2017.

Argentina hosted the Second Western Hemisphere Counterterrorism Ministerial in July, which included 18 participating countries. At the Ministerial, countries affirmed that ISIS, al-Qa'ida, and their affiliated organizations were a terrorist threat, expressed concern about Hizballah activities in the hemisphere, and recognized ELN as a threat to regional stability. At the Ministerial, Argentina, Brazil, Paraguay, and the United States established the Regional Security Mechanism (RSM). The RSM - a reconstituting of the previous " $3+1$ " initiative - focuses on the threats of transnational crime and terrorism in the region. In November 2019, the RSM held its first experts meeting in Asuncion, Paraguay, bringing together officials from intelligence, law enforcement, border security, financial intelligence, financial regulatory, and foreign affairs agencies from the four member countries.

In October, the Organization of American States' Inter-American Committee against Terrorism (OAS/CICTE) formally announced the launch of the Inter-American Network on Counterterrorism, with funding support from Chile and the United States. The network, the only one of its kind in the Americas, will operate on a 24/7 basis among OAS member states. By facilitating communication among points of contact designated by each member state, countries of the Western Hemisphere will be able to respond more effectively to terrorist threats.

\section{ARGENTINA}

Overview: During 2019, Argentina continued to focus its counterterrorism strategy on the TriBorder Area (TBA) of Argentina, Brazil, and Paraguay where suspected terrorism financing networks operate. Robust U.S.-Argentine law enforcement and security cooperation continued in 2019. Argentina created a "Public Register of People and Entities Linked to Acts of Terrorism and their Financing," which it used to designate Hizballah as a terrorist entity. On July 19, Argentina hosted the Second Western Hemisphere Counterterrorism Ministerial in Buenos Aires.

2019 Terrorist Incidents: There were no reported terrorist incidents in Argentina during 2019.

Legislation, Law Enforcement, and Border Security: On July 16, then-President Macri signed a presidential decree creating a "Public Register of People and Entities Linked to Acts of Terrorism and their Financing" and added Hizballah to the registry on July 17. The registry, which is accessible to the public and controlled by the Ministry of Justice, derives its listings from UN designated terrorist groups, prosecutions for terrorism, and the Financial Information Unit (UIF).

Plans to introduce changes to the criminal code to reform Argentina's legal framework for terrorism cases remained delayed in 2019. The executive branch drafted and submitted new 
legislation to Congress for approval in March 2019; however, it has not yet been approved. In January 2019, then-President Macri issued a presidential decree creating an asset forfeiture regime enabling asset forfeiture in terrorism and terrorism financing cases without the need for a conviction.

Multiple security agencies maintained specialized law enforcement units that have substantial capabilities to respond to criminal activities, including terrorist incidents. Argentina continued to develop its nationwide network of law enforcement Intelligence Fusion Centers. By deploying additional technology, personnel, and equipment, the Argentine Ministry of Security (MOS) improved its law enforcement capacity at high-risk ports of entry along its northern border. The MOS and its federal security forces continue to incorporate biometric data into their fight against international terrorism and transnational crime.

Argentina strengthened its intelligence and analysis activities through its participation in the Tripartite Command, an interagency security mechanism created by Argentina, Brazil, and Paraguay to exchange information and combat transnational threats, including terrorism, in the TBA.

The lack of justice for Hizballah's 1994 bombing of the Argentine Israelite Mutual Association (AMIA) remained in the news and prompted a proposal to reform the criminal code by allowing trials in absentia. In March, the Argentine Supreme Court rejected an appeal submitted by former Argentine President Fernandez de Kirchner to avoid oral trial for allegedly covering up Iran's involvement in the AMIA attack by signing a Memorandum of Understanding with the Government of Iran in 2013. The Supreme Court ratified a pre-trial detention order against her; however, the Argentine Senate decided not to vote to remove her parliamentary immunity from arrest. In December, the Argentine federal trial court hearing the case revoked the pre-trial detention order, finding that her investiture as vice president had removed the risk she could flee.

Argentine prosecutors charged seven Iranians (and then-Iranian President Rafsanjani) in October 2006 as suspects in the AMIA bombing in what is now known as the "AMIA I" case, but the lead prosecutor died under suspicious circumstances, and the Iranian suspects have never been brought to justice. A four-year trial seeking to determine local complicity in the deviation of the investigation, commonly known as the "AMIA II" case, concluded on February 28 with the acquittal of former Argentine President Carlos Menem, the convictions of former federal judge Juan José Galeano and then-intelligence chief Hugo Anzorreguy, and the acquittals and/or suspended sentences for the other 10 individuals accused.

Countering the Financing of Terrorism: Argentina is a member of the Financial Action Task Force (FATF), as well as the Financial Action Task Force of Latin America (GAFILAT), a FATF-style regional body. Its FIU, known as the Financial Information Unit Argentina (UIF), is a member of the Egmont Group. Recent reforms have empowered the UIF to act as the lead agency on all financial intelligence matters. The TBA is one of the principal routes into Argentina for multi-billion-dollar trade-based money laundering, counterfeiting, drug trafficking, and other smuggling operations. In addition, many of the money laundering organizations in the TBA have known or suspected links to the terrorist organization Hizballah. 
In 2019, the UIF ordered the freezing of assets in the country belonging to Hizballah and its members after officially designating the group a terrorist organization. The government also created a National Committee for Combating Money Laundering and Terrorist Financing.

In July 2019, the FIU enacted regulation for credit and debit card operators, prepaid cards, and other means of payment to implement a new risk-based approach in line with FATF recommendations.

Countering Violent Extremism: There were no changes in 2019.

International and Regional Cooperation: On July 19, Argentina hosted the Second Western Hemisphere Counterterrorism Ministerial in Buenos Aires. Argentina is a member of the RSM and participated in the first experts-level meeting of the RSM November 12-13 in Asuncion. Argentina participated in the Organization of American States (OAS) Inter-American Committee against Terrorism and the Southern Common Market Special Forum on Terrorism. The United States and Argentina co-hosted a U.S. DOJ-sponsored Practitioner's Workshop August 1-2 in Iguazu on the Argentine side of the TBA. The workshop included prosecutors, judges, law enforcement investigators, financial intelligence/sanctions officials, and intelligence officials from Argentina, Brazil, Paraguay, and the United States.

\section{BRAZIL}

Overview: Brazil and the United States maintained strong counterterrorism cooperation in 2019, building on collaborative efforts underway since the 2016 Summer Olympics. The Brazilian Federal Police (PF), Brazil's lead counterterrorism agency, worked closely with the United States and other nations' law enforcement entities to assess and mitigate potential terrorist threats. The Brazilian government continued to support CT activities, which included third-country technical assistance for controlling sensitive technologies and investigating fraudulent travel documents.

2019 Terrorist Incidents: There were no terrorist attacks reported in Brazil in 2019.

Legislation, Law Enforcement, and Border Security: There were no major changes to counterterrorism legislation in 2019.

In January, President Jair Bolsonaro combined the Ministries of Justice and of Public Security, with PF under the authority of the new super ministry.

In August, Brazil promulgated into law the International Convention for the Suppression of Acts of Nuclear Terrorism, to which it became a signatory on September 14, 2005.

The FBI, in coordination with PF, issued a notice in August seeking information about Mohamed Ahmed Elsayed Ahmed Ibrahim, an Egyptian suspected al-Qa'ida operative and facilitator living in Brazil. The public notice - the first of its kind for the region - stated that Ibrahim was being sought for questioning for his alleged involvement in plotting attacks against the United States and its interests. The investigation is ongoing. 
There were no new arrests or convictions related to 2016's Operation Hashtag, which dismantled a loose, online, pro-ISIS network prior to the 2016 Olympics, or Operation Atila, which began in 2017 to investigate the use of mobile communication applications to promote terrorist groups. There were no new arrests or convictions under Operation Bravata, launched by PF in 2018 to combat racist and terrorist threats made online.

Brazilian authorities continued to work with other concerned nations - particularly the United States - to counter document fraud. Regional and international joint operations successfully disrupted numerous document vendors and facilitators, as well as related human smuggling networks.

During President Bolsonaro's March visit to Washington, DC, PF agreed to send its first permanent liaison officer to CBP's National Targeting Center to exchange real-time information on persons of interest traveling through Sao Paulo's Guarulhos International Airport (GRU) - the busiest airport in South America. CBP continued the pilot phase of the Joint Security Program (JSP) in GRU with the goal of identifying high-risk air travelers and contraband arriving to and departing from Brazil. JSP officers work side-by-side with Brazilian law enforcement and border control counterparts to identify travelers with links to terrorism and narcotics, weapons, currency, or alien smuggling. Due to fiscal restraints, the PF has yet to assign full-time, permanent staff to the JSP.

In March, the Brazilian Ministry of Justice and Public Security and the FBI completed an information sharing arrangement that creates a framework for Brazil to adopt a U.S.-standard biometrics collection system. The joint biometrics program's focus is to counter identity fraudbased travel in GRU and in the TBA of Argentina, Brazil, and Paraguay.

Countering the Financing of Terrorism: Brazil is a member of the FATF and GAFILAT. Its FIU, the Council for Financial Activities Control (COAF), is a member of the Egmont Group. Brazil made progress mitigating the shortcomings identified in its third-round FATF mutual evaluation report from 2010, and it continued to address the remaining deficiencies ahead of its mutual evaluation scheduled for 2021.

In February, Brazil's Congress passed a Countering Financing of Terrorism bill, which President Bolsonaro signed into law in June. The law enables Brazilian authorities to designate terrorists and terrorism financiers domestically and allows for the immediate freezing of assets of terrorism financiers designated domestically, as well as under UN Security Council resolutions. The law also updates legislation used to combat criminals and corporations engaged in money laundering, bringing Brazil's legislative framework more in line with international standards.

Countering Violent Extremism: The Brazilian Congress and various government agencies, including PF and Ministry of Foreign Relations, organized or participated in conferences addressing international terrorism, with a particular emphasis on countering "online radicalization and preventing the use of the internet for terrorist purposes." 
International and Regional Cooperation: Brazil participated in regional counterterrorism fora, including the OAS Inter-American Committee against Terrorism, the BRICS (Brazil, Russia, India, China, and South Africa) Joint Working Group on Counterterrorism, and the Southern Common Market's working group on terrorism and sub-working group on financial issues. Argentina, Brazil, and Paraguay coordinated law enforcement efforts in the TBA by means of their Trilateral Tri-Border Area Command.

Brazil is a member of the RSM.

\section{CANADA}

Overview: Canada remains one of the strongest and most able U.S. partners in the global fight against terrorism, and CT cooperation with Canada is excellent. Prosecutors continued to face challenges in bringing to trial cases underpinned by battlefield evidence. Canada generally declined to repatriate FTFs or family members from Syria and Iraq. The government took the position that it had no legal obligation to facilitate their return to Canada, including those in the custody of Syrian Democratic Forces, but acknowledged a Canadian Charter right to return if the individuals approached Canadian territory.

2019 Terrorist Incidents: There were no terrorist incidents in 2019.

Legislation, Law Enforcement, and Border Security: Bill C-59 received royal assent in June 2019. Among other provisions, the bill permits active cyber operations, strengthens the Canadian Security Intelligence Services' ability to disrupt terrorist plots, and revises the criminal offense of counseling terrorism.

Canada listed a number of terrorist organizations in 2019. On February 11, Canada listed Harakat Sawa'd Misr (HASM) as a terrorist entity under the Criminal Code and renewed the existing 56 entities on the list following the required two-year review. On June 21, the Al-Ashtar Brigades was listed as a terrorist entity in the Criminal Code. On June 26, Canada designated the REMT group Blood \& Honor and its armed branch Combat 18 as terrorist organizations. On April 23, Canada added three Sikh-Canadian activists to its no-fly list. Two individuals, Bhagat Singh Brar and Parvkar Singh Dulai, have filed legal challenges.

Canada opened some new terrorism prosecutions while others remain ongoing:

- In January, Hussam Eddin Alzahabi and a minor were arrested in Kingston, Ontario, and the minor was charged with terrorism-related offenses including knowingly facilitating a terrorist activity, counseling a person to use an explosive or other lethal device in a public place with the intent to cause death or serious bodily harm, uttering a threat, and "making or having in his possession or under his care of control an explosive substance" designed to endanger life "or cause serious damage to property." The minor appeared in court on April 23 and has been detained since then.

- In January and February, Rehab Dughmosh was convicted of four offenses related to an attempt to aid ISIS (two counts of assault with a weapon, one count of carrying a weapon, 
and one count of leaving Canada for the purpose of committing a criminal offense) and sentenced to seven years in prison for attacking workers at a Canadian Tire store on June 3, 2017. She also attempted to travel to Syria in April 2016.

- On February 8, Alexandre Bissonnette was sentenced to 40 years in prison without the possibility of parole for the January 29, 2017, attack on the Centre Culturel Islamique de Québec. The Crown appealed the sentencing on March 12, seeking 50 years in prison with parole only possible after 25 years.

- On February 28, Pamir Hakimzadeh was sentenced to four years for one count of leaving Canada (in September 2014) to participate in a terrorist activity. On June 28, he was released after completing his sentence and the judge found Hakimzadeh had not continued to voice extremist views.

- On August 27, the Court of Appeal for Ontario ordered a new trial for VIA Rail terror offenders Raed Jaser and Chiheb Esseghaier based on improper jury selection. The offenders chose trial by judge alone, to commence on September 14, 2020. The Crown appealed the decision on November 19.

- On October 16, Awso Peshdary's lawyers filed a charter challenge seeking a stay of proceedings in his long-running terror trial, alleging government secrecy around evidence destruction.

- On October 24, Abdullahi Ahmed Abdullahi was extradited to the United States to face charges of conspiring to provide and providing material support to ISIS recruits.

- On November 29, the Quebec Court of Appeal rejected an appeal from Ismael Habib, who is currently serving a nine-year prison sentence for attempting to join ISIS in Syria in 2013.

- On December 6, Ikar Mao was arrested in Ontario and charged with participating in the activities of a terrorist group and leaving Canada to take part in a terrorist activity. Mao earlier had faced terrorism charges in Turkey prior to his return to Canada in October.

Countering the Financing of Terrorism: Canada is a member of the FATF and the Asia/Pacific Group on Money Laundering (APG), a FATF-style regional body. Its FIU, the Financial Transactions and Reports Analysis Centre of Canada (FINTRAC - CANAFE), is a member of the Egmont Group.

Canada's Budget 2019 included an integrated plan to combat money laundering and terrorist financing, including strengthening the Royal Canadian Mounted Police's operational and investigative capacity, as well as strengthening FINTRAC's operational capacity to increase compliance examinations and enforcement in the real estate sector.

Countering Violent Extremism: Canada has announced several new initiatives and funding:

- On February 7, Canada announced the launch of the National Expert Committee on Countering Radicalization to Violence. It will advance the work of the Canada Centre for Community Engagement and Prevention of Violence and further the National Strategy on Countering Radicalization to Violence.

- On February 11, Canada announced \$1.33 million over five years to the John Howard Society of Ottawa to pilot the Project ReSet program, designed to provide at-risk persons with individualized intervention plans. 
- On March 6, Canada announced a grant of $\$ 279,329$ over three years to the University of Ontario Institute of Technology to study REMT, which Canada sometimes refers to as "ideologically motivated violent extremism," and to conduct analysis of online content and media coverage.

- On March 27, the Canada Centre concluded a week of events to further Canada's National Strategy on Countering Radicalization to Violence.

- On June 26, Canada announced a contribution of up to \$761,145 to Tech Against Terrorism for the creation of a digital repository to assist smaller companies to detect and remove online terrorist content. Canada also will convene a Youth Summit on Countering Violent Extremism Online to learn about online threats and develop effective tools to combat them.

- On August 21, Canada announced \$231,580 over three years to the Centre of Expertise and Training on Religious Fundamentalism, Political Ideologies, and Radicalization for research on what it terms "far-right extremism."

International and Regional Cooperation: Canada became co-chair (with Morocco) of the Global Counterterrorism Forum in September 2019 for a two-year term. Canada played a major role in the Global Coalition to Defeat ISIS in 2019 and has been a leading contributor to the Coalition's military support and humanitarian assistance. Canadian Special Forces in Iraq work with local counterparts to defeat ISIS. Canada also leads the non-combat NATO Mission in Iraq.

\section{COLOMBIA}

Overview: The National Liberation Army (ELN) has seen a resurgence and in some areas of Colombia is filling the void left by FARC ex-combatants who left the battlefield. Colombian authorities estimate there are around 3,000 active members of the ELN, 1,400 of whom the government claims are camped across the border in Venezuela. Colombian authorities state publicly there are 36 ELN camps strategically located on the Venezuela side of the ColombiaVenezuela border. As of December 2019, roughly 13,000 FARC ex-combatants (including former rank-and-file guerrillas and militia) continue to participate in the reintegration process based on the 2016 peace accord. Ongoing challenges to peace accord implementation and continued security vacuums have created risk for terrorist activity and attacks on civilians, security forces, and infrastructure in some areas in 2019. An estimated 2,600 FARC dissidents who never demobilized, left the peace process, or are new recruits, continued violent attacks, primarily to enable narcotics trafficking and other criminal activities, particularly in border regions and areas previously controlled by the former FARC.

Colombian-U.S. CT cooperation remains strong. Colombia has openly condemned ISIS and its objectives.

2019 Terrorist Incidents: In 2019, FARC dissidents and the ELN continued to commit crimes and acts of terror throughout the country - including bombings, violence against civilian populations, and violent attacks against military and police facilities.

- In January, an ELN terrorist detonated a car bomb inside Colombia's national police academy in Bogota, killing 22 cadets and injuring 87. 
- Through the end of December, IEDs suspected to have been placed by groups such as FARC dissidents, ELN members, and others have killed 10 and wounded 56 police officers, military members, and civilians participating in manual coca eradication operations.

Legislation, Law Enforcement, and Border Security: There were no changes to terrorismrelated legislation and investigation procedures in 2019.

Colombian border security remained an area of vulnerability as law enforcement officers continued to face the challenge of working in areas with porous borders, difficult topography, illegal armed groups, and drug trafficking.

The U.S. and Colombian governments signed the first of two arrangements to exchange terrorist screening data in December 2019, with an aim to detect and prevent terrorist travel in line with UNSCR 2396 obligations.

In August 2019, U.S. Department of Justice representatives at U.S. Embassy Bogota coordinated a U.S.-Colombia Bilateral ELN Case Development Coordination Conference. The conference brought together 60 U.S. law enforcement agents and prosecutors from across the United States and their Colombian counterparts to facilitate ELN case development in the United States by harmonizing evidence collection procedures with Colombian legal standards.

Countering the Financing of Terrorism: Colombia is a member of GAFILAT. Its FIU, the Unidad de Informacion y Analisis Financiero is a member of the Egmont Group. There were no significant updates in 2019.

Countering Violent Extremism: In 2019, roughly 13,000 FARC ex-combatants and former militia members who demobilized under the 2016 peace accord continued to participate in social and economic reincorporation activities. Colombia continued to employ a modern, multi-agency approach to CVE, with a focus on encouraging individual guerrillas (primarily the ELN) to demobilize. The number of members of armed groups who demobilized individually declined from 635 in 2018 to 414 in 2019. Of the 414 members, 161 were minors.

International and Regional Cooperation: Colombia is a founding member of the Global Counter Terrorism Forum and continues to lead in providing security training and assistance to other countries in the region. In 2019, Colombia proposed hosting the Third Western Hemisphere Counterterrorism Ministerial in January 2020. Throughout 2019, Colombia laid the groundwork for declaring Hizballah a terrorist organization and commenced an interagency process to formalize prohibitions against support for Hizballah, as well as necessary legislation and regulations to implement the decision.

\section{CUBA}

Overview: Cuba was designated as a State Sponsor of Terrorism in 1982 because of its long history of providing advice, safe haven, communications, training, and financial support to guerrilla groups and individual terrorists. This designation was rescinded in 2015. Cuba 
maintains close and collaborative ties with designated state sponsors of terror such as Iran and North Korea. The Cuban regime continues to host ELN leaders associated with now-defunct peace talks to reside in Cuba, despite Colombia's repeated requests for their extradition. Cuba also continues to harbor multiple fugitives who committed or supported acts of terrorism in the United States. The U.S. Department of State certified Cuba as "not cooperating fully" with U.S. counterterrorism efforts for 2019, the first such certification of Cuba since 2015.

2019 Terrorist Incidents: There were no terrorist attacks in Cuba in 2019.

Legislation, Law Enforcement, and Border Security: Citing peace negotiation protocols, Cuba refused Colombia's request to extradite 10 ELN leaders living in Havana after that group claimed responsibility for the January 2019 bombing of a Bogota police academy that killed 22 people and injured 87 others. On October 11, Colombia filed extradition requests for ELN leaders Victor Orlando Cubides (aka "Pablo Tejada") and Isreal Ramirez Pineda (aka "Pablo Beltran") with the Cuban government, which has pointedly not responded. Though Cuba's government denies allowing ELN members to plan terrorist attacks from its territory, fugitive ELN terrorists continue to live in Havana, shielded by the Cuban regime, while ELN members continue to attack, kidnap, and murder in Colombia.

In addition to ELN terrorists, there was credible reporting that FARC dissidents who abandoned the peace process in Colombia traveled to Havana to seek the regime's support. On July 28 during the closing remarks of the Sao Paolo Forum in Caracas, Nicolas Maduro stated that Iván Márquez and Jesús Santrich - former FARC leaders who fled Colombia after abandoning the peace process and announced a return to terrorist activities - were both welcome in Venezuela. Cuba is a key supporter of Maduro's narco-regime and is an active participant in maintaining Maduro's authority.

Cuba also harbors several U.S. fugitives from justice wanted on charges of political violence, many of whom have resided in Cuba for decades. For example, the Cuban regime has refused to return Joanne Chesimard, aka Assata Shakur, a fugitive on the FBI's Most Wanted Terrorists List, who was convicted of executing New Jersey State Trooper Werner Foerster. Cuba also has refused to return William "Guillermo" Morales, a fugitive bomb maker for the Armed Forces for National Liberation (FALN), who is wanted by the FBI and escaped detention after being convicted of charges related to domestic terrorism; Ishmael LaBeet, aka Ishmael Muslim Ali, who received eight life sentences after being convicted of killing eight people in the U.S. Virgin Islands in 1972 and hijacking a plane to flee to Cuba in 1984; Charles Lee Hill, who has been charged with killing New Mexico state policeman Robert Rosenbloom in 1971; and Ambrose Henry Montfort, who used a bomb threat to hijack a passenger aircraft and fly to Cuba in 1983. Cuba is also believed to host or have hosted U.S. fugitive terrorists Catherine Marie Kerkow and Elizabeth Anna Duke. The Cuban government provides housing, food ration books, and medical care for all of the fugitives residing there.

Countering the Financing of Terrorism: Cuba is a member of the GAFILAT. Its FIU, the Dirección General de Investigación de Operaciones Financieras, is a member of the Egmont Group. There were no significant updates in 2019. 
Countering Violent Extremism: Cuba conducted no CVE efforts in 2019.

International and Regional Cooperation: Cuba is an inactive member of the OAS and is not a member of NATO or the OSCE.

\section{MEXICO}

Overview: Counterterrorism cooperation between Mexico and the United States remained strong in 2019. There was no credible evidence indicating international terrorist groups established bases in Mexico, worked directly with Mexican drug cartels, or sent operatives via Mexico into the United States. International supporters and facilitators of terrorist groups such as Hizballah, al-Qa'ida, and ISIS are active elsewhere in the Western Hemisphere, and the U.S. southern border remains vulnerable to potential terrorist transit. In 2011, the Mexican government aided U.S. efforts to disrupt an Iranian plot to assassinate the Saudi ambassador to the United States. An operative, who planned to contact a Mexican criminal organization on behalf of elements of the Iranian government, was sentenced in 2013 in a federal court in New York City to 25 years in prison after pleading guilty for his role in the plot.

2019 Terrorist Incidents: A Mexican ecological extremist movement called Individualistas Tendiendo a lo Salvaje, or Individualists Tending to the Wild, placed five rudimentary timed explosive devices constructed from pyrotechnics and pipes at commercial centers, including a shopping center, a Walmart, and a movie theater, in separate incidents in the State of Mexico between December 2018 and May 2019. At least one device detonated (at the theater) and injured a theater employee. Mexican law enforcement has not identified any suspects, nor made any arrests.

Legislation, Law Enforcement, and Border Security: In July, Mexico's Congress passed an asset forfeiture bill; there were no additional changes to Mexico's counterterrorism legislation in 2019. The government lacked adequate laws prohibiting material support to terrorists and relied on counterterrorism regimes in other countries to thwart potential threats.

The Center for National Intelligence (CNI), housed within the Secretariat of Security and Citizen Protection, was the lead agency for detecting, deterring, and preventing terrorist threats during 2019. The Mexican Prosecutor General's Office (FGR) was the lead agency for investigating and prosecuting terrorism-related offenses. In 2019, FGR underwent a transition to reorganize, professionalize, and develop interdisciplinary investigation teams based on 2018 legislation. Impunity remained a problem with extremely low rates of prosecution for all crimes.

Mexico made significant efforts to strengthen its border controls and screen more individuals who entered its territory in 2019, deploying 27,000 military and security forces to enforce migration laws. While unauthorized migration has decreased, an illicit flow of people and goods continued to transit Mexico's southern border, and corruption still plagued Mexican ports of entry.

Countering the Financing of Terrorism: Mexico is a member of FATF and GAFILAT. Mexico is also a cooperating and supporting nation of the Caribbean Financial Action Task 
Force (CFATF) and is an observer of the Committee of Experts on the Evaluation of AntiMoney Laundering Measures, two other FATF-style regional bodies. Its FIU, the Financial Intelligence Unit-Mexico, is a member of the Egmont Group.

In July, the Mexican Congress passed a sweeping asset forfeiture bill that provides Mexican prosecutors with stronger tools to seize assets of illicit origin and those used to commit crimes in a process separate from any related criminal matter. The legislation incorporated many best practices from Latin American countries and the UN's asset forfeiture model. Congress also passed two laws obliging currency exchange outlets and stockbrokers to avoid using funds that could finance terrorism.

Countering Violent Extremism: There were no changes in 2019. Mexico lacks official policies, initiatives, or programs to counter terrorist radicalization and recruitment.

International and Regional Cooperation: On the margins of the UN General Assembly, Mexico issued a joint declaration with its MIKTA partners (Indonesia, South Korea, Turkey, and Australia) condemning "terrorism and violent extremism" and "expressing grave concern for the use of the internet for these purposes, including the incitement to discrimination and violence motivated by hate, racism, xenophobia and religious intolerance." As part of its membership in the UN Human Rights Council, Mexico presented and led adoption of a resolution promoting respect for human rights and victims of terrorism while countering terrorism. Mexico is an active member of the OAS Inter-American Committee against Terrorism. In the wake of the August 3 terrorist attack in El Paso, Texas, that resulted in the deaths of Mexican citizens, the Mexican Foreign Ministry pledged to lead a regional effort to combat white supremacist terrorism.

\section{PANAMA}

Overview: Throughout 2019, Panama remained a willing partner for bilateral and multilateral cooperation in countering terrorism. As a transit country for illicit goods, money, and migrants, Panama's geographic location makes its willingness to engage on counterterrorism important for regional security. In 2019, Panama held national elections, resulting in a near full turnover of key government offices in July 2019. Under the new leadership of President Laurentino "Nito" Cortizo, the Panamanian government continued to cooperate on counterterrorism.

Principal areas of CT cooperation with the United States were maritime sanctions and migration. The Panamanian government de-flagged approximately 60 ships engaging in sanctions-violating actions, in support of U.S. sanctions. Through the joint Special Interest Alien (SIA) Joint Task Force, a bilateral mechanism to share information on SIAs and KSTs and detain and/or deport them as needed, the Panamanian government cooperated with U.S. authorities on several CTrelated cases this year. Panama agreed to an Action Plan to address its grey-listing by the Financial Action Task Force (FATF) with concrete measures to be completed in stages by May 2020 and September 2020.

Panama remained the first and only Latin American member of the Defeat-ISIS Coalition and continues to be involved in the Coalition's Counter-Terrorism Finance Working Group. The 
Government of Panama participated in the November 2019 working group meeting in Luxembourg.

2019 Terrorist Incidents: There were no incidents related to international terrorism in Panama during 2019.

Legislation, Law Enforcement, and Border Security: Panama does not have comprehensive counterterrorism legislation or a robust counterterrorism legal framework. While the country does not have a formal coordinating authority below the cabinet level, officials from the National Security Council, the National Border Service (SENAFRONT), the National Migration Service (SNM), and National Police (PNP) met frequently internally and with U.S. government officialsto efficiently coordinate and act on migration alerts, resulting in the detention and deportation of travelers who represented a security risk. Consistent with UNSCR 2396 obligations, Panama collected biographic and biometric data, shared terrorism identity information with regional partners, collected and analyzed API and PNR, and participated in INTERPOL.

The SIA Joint Task Force cooperated with U.S. authorities on several CT-related cases. The Task Force includes assignees from PNP, SENAFRONT, National Air and Naval Service, SNM, and Panama's intelligence service (Consejo), as well as the U.S. Embassy's DHS Immigration and Customs Enforcement and Customs and Border Protection teams. Since its creation in the previous year, the Panamanian government has provided physical space for the Task Force to operate, and the Task Force has supported several CT-related investigations.

While Panama's own intelligence collection capacity is limited, the Panamanian government acted as a willing partner in responding to U.S. requests. Logistical challenges, such as routing flights for deportations and a lack of diplomatic relationships with some migrants' countries of origin, continue to limit the Government of Panama's ability to deport. The Cortizo government signaled a willingness to increase deportations but requested U.S. government assistance to do so.

The Ministry of Security and the National Customs Authority solicited bids to address the country's lack of cargo scanners. At the time of this report, the scanners project was pending the Panamanian government's choice of a company to implement the project using bilateral funds. The lack of scanners significantly limits the government's ability to analyze cargo transiting the country, including at Tocumen International Airport, which has the highest number of passenger movements in the region, and entry and exit of the Colon Free Trade Zone.

Panama continued to cooperate with U.S. law enforcement on ongoing counterterrorism cases in 2019, including individuals linked to Hizballah. However, the Panamanian government's ability to investigate financial support to terrorist-related organizations remained limited.

Countering the Financing of Terrorism: Panama is a member of GAFILAT. Its FIU, the Financial Analysis Unit Panama (UAF-Panama), is a member of the Egmont Group. UAFPanama and one of its departments covers CFT-related reviews of information and prevention efforts related to countering the financing of terrorism. 
In June 2019, the FATF added Panama to its grey list of jurisdictions subject to ongoing monitoring due to strategic deficiencies and a lack of progress in the effectiveness of its AML/CFT regime. FATF specifically noted that Panama must update the terrorism finance section of its National Risk Assessment and ensure that its findings inform national CFT policies and result in corresponding changes in activities of relevant competent authorities. Panama agreed to an Action Plan with concrete measures to be completed in stages by May 2020 and September 2020.

With support from the World Bank, Panama updated Chapter 5 of its National Risk Assessment, which relates to terrorism financing. In February 2019, the Panama Maritime Authority, which oversees the world's largest ship registry, de-flagged 59 Iranian vessels linked to sanctionable trade as outlined in UN resolutions and the U.S. Department of the Treasury's Specially Designated Nationals and Blocked Persons List.

Countering Violent Extremism: There were no changes in 2019.

International and Regional Cooperation: Panama is an active participant in the United Nations and regional security initiatives such as the OAS Inter-American Committee Against Terrorism (OAS-CICTE). In October 2019, Panama hosted a CICTE workshop as part of CICTE's "Technical Assistance for Implementation of Financial Sanctions against Terrorism" project. The workshop focused on financial sanctions and domestic listings and included participation from 10 different Panamanian government institutions.

In April 2019, Panama and Dominican Republic held a peer review exercise to analyze the implementation of UNSCR 1540 in both countries and to identify areas for regional collaboration and coordination.

Separately, Panama steadily increased its cooperation with neighbors to better secure its borders against transnational criminal organizations (TCO). During 2019, Panama signed information sharing agreements with Costa Rica and Colombia to enable further cooperation to combat TCO activity. Panamanian security forces also conducted operations with Costa Rica and Colombia to identify TCO routes and networks.

\section{PARAGUAY}

Overview: In 2019, the Government of Paraguay continued to be a receptive partner on counterterrorism cooperation with the United States. Paraguay's challenges stem from ineffective immigration, customs, financial, and law enforcement controls along its porous borders, particularly the Tri-Border Area (TBA) with Argentina and Brazil, and its dry border with Brazil from the TBA to Pedro Juan Caballero.

Since 2008, persons claiming to be part of the Paraguayan People's Army (EPP) - a domestic criminal group initially dedicated to a socialist revolution in Paraguay - have been involved in violence meant to extort and intimidate the population and local governments in the northern departments of Concepcion, San Pedro, and Amambay. Paraguayan authorities officially 
consider the EPP and its offshoots - Mariscal Lopez's Army (EML), and the Armed Peasant Association (ACA), which reemerged in May - as organized criminal groups rather than terrorist organizations. However, public discourse of Paraguayan leaders occasionally refers to them informally as terrorist organizations. The Government of Paraguay believes the EPP is a small, decentralized group of 20-50 members. EPP, EML, and ACA's activities have consisted largely of isolated attacks on remote police and army posts, or against ranchers and peasants accused of aiding Paraguayan security forces. Ranchers and ranch workers in northeastern Paraguay, including members of the Mennonite community, claimed the EPP frequently threatened both their livelihoods and personal security. As of December 1, authorities believe the EML held one hostage: Felix Urbieta, who was kidnapped October 2016. In April, the Paraguayan Internal Operational Defense Command (FTC) found an EPP pamphlet claiming that police officer Edelio Morinigo, who had been the longest-held victim, was deceased. Although the FTC officially communicated the news to Morinigo's family, the victim's remains have not yet been found.

2019 Terrorist Incidents: Alleged elements of the EPP and ACA continued to conduct killings and sabotage operations:

- On April 21, five ACA members held seven people hostage for less than two hours in Concepcion department. They burned two pickup trucks, two tractors, and a horse cart. Before fleeing, according to the victims, they railed against the production of genetically modified soybean and corn.

- On July 8, around 20 EPP members, including leader Osvaldo Daniel Villalba Ayala, held hostage 17 employees of a farm located in Amambay department. The EPP group waited for the farm's administrator to arrive and murdered him as soon as he stepped out of his car. The majority of the EPP group allegedly included indigenous individuals from nearby areas.

- On October 18, a bomb located in the back of a pickup truck exploded as it was driving through a rural road in Concepcion department. The driver and the other three accompanying persons were not harmed. On November 15, ACA members claimed responsibility for the explosion.

Legislation, Law Enforcement, and Border Security: The Paraguayan government continued to make use of a 2013 counterterrorism law that allows for the domestic deployment of the Paraguayan military to counter internal or external threats. The FTC, the joint task force charged with countering the EPP, consists of around 800 military, supported by 471 Paraguayan National Police (PNP) officers, as well as National Anti-Drug Secretariat (SENAD) personnel. The PNP Secretariat for the Prevention and Investigation of Terrorism officially handles CT functions, although other PNP units and agencies such as SENAD work such cases as well, particularly when related to drug trafficking. In 2018, Paraguayan President Mario Abdo Benitez inaugurated the new headquarters of the National Intelligence System (SINAI) service, composed of a National Intelligence Council (CNI) and a National Intelligence Secretariat (SNI), which report directly to the President. The purpose of the SINAI is "detecting, neutralizing and counterbalancing the actions of domestic and international terrorist groups, and of transnational criminal organizations." The first meeting of the CNI took place on November 26, on the oneyear anniversary of SNI's formation. Military forces and police officials continued to operate 
jointly in the San Pedro, Concepcion, and Amambay departments against the EPP, with limited success.

On August 9, President Abdo Benitez signed decree 2307, designating Hizballah, Hamas, alQa'ida, and ISIS as terrorist organizations. On October 23, Congress passed legislation allowing the Paraguayan government to freeze assets linked to terrorism and its financing, which the president signed into law November 18.

On June 12, a court sentenced imprisoned EPP leader Alcides Oviedo Britez to 40 years in prison for masterminding the kidnapping of teenager Arlan Fick. On September 26, a court sentenced Reinaldo Zeballos and Santiago Mercado Sosa to 13 years in prison for "terrorist association" for providing logistical support to the EPP. On October 3, a court sentenced Maria Gloria Gonzalez, mother of EPP member Domingo Ovelar Gonzalez, to six years in prison for "terrorist association" for providing logistical support to the EPP.

The TBA has been attractive to individuals engaged in terrorist financing as the limited military, customs, and migration agency presence along these borders allows for a largely unregulated flow of people, goods, and money. Paraguay made strong efforts to provide more effective law enforcement and border security in 2019 , but these efforts were hampered by a lack of interagency cooperation and information sharing, as well as corruption within security, border control, and judicial institutions.

Following the 2017 establishment of Paraguay's Seized and Forfeited Asset Management Secretariat (SENABICO), more than $\$ 165$ million in seized goods are now under SENABICO administration. SENABICO is charged with administering confiscated property and assets associated with criminal activity, including terrorism financing. However, interagency disputes and a lack of understanding of advance sale legislation have prevented SENABICO from auctioning any of the assets under its administration.

Countering the Financing of Terrorism: Paraguay is a member of the GAFILAT. Its FIU, the Financial Intelligence Unit-Paraguay (UAF-SEPRELAD), is a member of the Egmont Group. In 2019, Paraguay continued its work for the GAFILAT mutual evaluation, which started November 18. On December 26, 2019, the Paraguayan Senate had passed the last of a packet of 12 draft laws that would tighten counterterrorism finance enforcement.

Countering Violent Extremism: Paraguay had no CVE program in 2019.

International and Regional Cooperation: Paraguay continued to support counterterrorism efforts in regional and multilateral organizations. Paraguay actively participated in the Second Hemispheric Ministerial Conference against Terrorism meeting held in Argentina in July. Paraguay is a member of the RSM and hosted the RSM's first technical meeting in November. 
Paraguay participated in the OAS and its Inter-American Committee Against Terrorism. It continued to collaborate with Argentina and Brazil on border security initiatives, regional exchanges, and law enforcement projects. Argentina, Brazil, and Paraguay coordinated law enforcement efforts in the TBA via their Trilateral Tri-Border Area Command.

\section{PERU}

Overview: Peru successfully hosted the Pan American and Parapan American Games in 2019, with 8,500 athletes competing over 38 days across 20 venues - unprecedented in scale and duration. The U.S. government coordinated with Peruvian security services to provide security support to U.S. athletes, teams, and attendees. Peru's execution of its comprehensive security plan for the Games enabled effective responses to several emerging threat streams, including arresting an alleged ISIS sympathizer.

On January 12, Peru began retrying on terrorism charges Muhammad Ghaleb Hamdar, a Lebanese citizen suspected of links to Hizballah currently serving a sentence on document fraud. If convicted, Hamdar would represent the first terrorism conviction of a Hizballah operative in South America.

President Martín Vizcarra reaffirmed Peru's commitment to restore law and order in the Valleys of the Apurímac, Ene, and Mantaro Rivers (VRAEM) by its national bicentennial in 2021. On November 1, despite protests and violence from coca farmers, Peru initiated coca eradication in the VRAEM for the first time.

Shining Path (Sendero Luminoso or SL) continued to operate in the VRAEM. Estimates vary, but most experts and Peruvian security services assess SL numbers between 250 and 300 members, including 60-150 armed fighters. SL collects "revolutionary taxes" from those involved in the drug trade and, for a price, provides security and transportation services for drug trafficking organizations to support its terrorist activities.

Víctor Quispe Palomino (aka Comrade José), a U.S. Drug Enforcement Agency Most Wanted Fugitive, continued to lead the SL's VRAEM's remnants, which he calls the Militarized Communist Party of Peru (MPCP). The son of an SL founder, Quispe Palomino allegedly oversees all MPCP illicit activities, including extortion, murder, and drug trafficking. A U.S. Department of State reward offers up to $\$ 5$ million for information leading to his arrest and/or conviction and the U.S. Department of Defense offers an additional \$1 million for information leading to his capture.

SL founder Abimael Guzmán and key accomplices are serving life sentences for terrorism in the 1980s and 1990s. Many former SL members and leaders have served 25 to 30-year sentences on terrorism charges and could be released in the coming months and years. Guzmán and other captured SL figures from earlier years deny association with the SL's VRAEM group. 
2019 Terrorist Incidents: The overall number of terrorist attacks and deaths of security forces attributable to terrorism declined in 2019. Four soldiers died in two terrorist incidents:

- On June 25, SL members killed three soldiers upon attacking a joint military-police patrol in the VRAEM town Vizcatán.

- On August 9, SL members killed one soldier and injured two others during a VRAEM patrol that resulted in the death of an SL operative in Ayacucho's Huanta province.

Legislation, Law Enforcement, and Border Security: Peru adopted multiple counterterrorism laws over the past 30 years. CT measures have broad public support. On October 19, Peru issued an executive decree with measures to neutralize domestic and transnational terrorist actions: the National Multisectoral Policy to Combat Terrorism.

Peru's significant 2019 counterterrorism actions included:

- Security forces' July 12 capture of SL military commander Julio Chapo, reportedly fifth in the SL military hierarchy and responsible for several killings and ambushes against security forces, in Huancavelica's Churcampa province of the VRAEM.

- The July 17 arrest and preventive detention of Brian Eugenio Alvarado Huari in Lima for alleged links to ISIS and plans to "attack foreigners" during Peru's 2019 Pan American Games.

- The July 29 capture of Serapio Cárdenas Villarroel (a.k.a. "Papicho") in Ayacucho's Huanta province in the VRAEM. A veteran SL member since the 1980s, Cárdenas is allegedly responsible for killing at least four people, including two police officers.

- The August 9 killing of SL central committee member and firearms specialist Juan Carlos Badajoz Vizarres (a.k.a. "Miguel" or "Bomba") during a joint patrol of the Peruvian National Police and Army in Huanta province.

Immigration authorities collected limited biometrics information from visitors to protect Peruvian border security. Peru implemented a new regulation June 15 allowing only Venezuelan citizens who hold passports and humanitarian visas to enter Peruvian territory. Visas were not required for citizens of most countries from Europe, Southeast Asia, or Central America (except El Salvador and Nicaragua).

The U.S.-Peru arrangement to exchange terrorist screening information became operational April 17, in time for Peru's hosting of the Pan American Games and Parapan American Games.

Countering the Financing of Terrorism: Peru is a member of the GAFILAT. Its FIU, the Financial Intelligence Unit of Peru, is a member of the Egmont Group. GAFILAT completed its mutual evaluation report of Peru in February 2019; the report contained several recommendations to enhance its AML/CFT regimes. The superintendent of banking, insurance, and private administrators of pension funds improved efforts to regulate cooperatives, including enhanced measures to prevent money laundering and terrorist financing.

Countering Violent Extremism: Peru promotes concrete measures to prevent and combat terrorism. The government's multi-sectoral VRAEM 2021 Development Strategy consolidates 
opportunities for sustainable social and economic development as part of its bicentennial vision. Peru's whole-of-government effort to foster alternative development and social inclusion in the VRAEM complements aggressive action against SL terrorism, propaganda, and recruitment.

On November 26, Peru co-hosted with Belgium, Poland, and the UK the UN Security Council's Arria-formula meeting on reintegrating former child combatants, reflecting Peru's focus on the needs of children who are vulnerable to social stigmatization and re-recruitment following their rescue from SL.

International and Regional Cooperation: Peruvian officials participated in CT activities in international organizations, including the UN, the OAS Inter-American Committee against Terrorism, the Union of South American Nations, and the Asia-Pacific Economic Cooperation. Peru chaired the UN Counter-Terrorism Committee for the second of a two-year term. Peru sent a high-level delegation to the Second Western Hemisphere Counterterrorism Ministerial Conference in Argentina in July and offered to host a future ministerial conference.

In November, the UN Counter-Terrorism Committee Executive Directorate conducted an assessment in Peru to identify good practices, challenges, and areas in which Peru may require technical assistance or provide technical assistance to other member states. Peru's CounterTerrorism Directorate, a Peruvian National Police branch, coordinated with police in other countries to track activities of domestic terrorist organizations abroad.

\section{TRINIDAD AND TOBAGO}

Overview: The threat from ISIS sympathizers in Trinidad and Tobago and the possible return of persons who traveled, or attempted to travel, to Syria and Iraq to fight with ISIS are the primary terrorism threats in the country.

Trinidad and Tobago and the United States continue to cooperate on CT investigations involving Trinidad and Tobago nationals. In 2019, Trinidad and Tobago substantially completed an action plan to address deficiencies in its anti-money laundering and countering the financing of terrorism regimes identified by the Financial Action Task Force (FATF) in 2017.

2019 Terrorist Incidents: There were no terrorist incidents reported in Trinidad and Tobago.

Legislation, Law Enforcement, and Border Security: Trinidad and Tobago's counterterrorism institutions remain challenged by deficiencies in staffing, interagency coordination, and funding. There are ongoing efforts to break down existing silos within the government, but distrust continues to impede coordination. Though no significant terrorismrelated prosecutions have been initiated, a lengthy judicial process can mean years before criminal prosecutions, including any related to terrorism, are or would be resolved.

Trinidad and Tobago has not changed its Anti-Terrorism Act since 2018. A 2019 amendment to the country's general law governing the availability of bail for criminal defendants now prohibits 
bail for anyone charged with certain offenses under the Anti-Terrorism Act that carry a jail sentence of 10 years or more.

The government's efforts to strengthen criminal justice institutions in 2019 included updated plea-bargaining and bail provisions and the introduction of judge-only trials, new courts, and improved technology to speed the disposition of criminal cases. The government also introduced draft legislation to enable new procedures for law enforcement officers and witnesses to identify suspects in criminal proceedings, to require audio or video recordings of suspect interviews, and to protect witnesses and victims testifying in court.

The Government of Trinidad and Tobago continued preparation of an operational plan to implement a national counterterrorism strategy adopted in 2018. An interagency government task force created in 2018 to develop policies related to the possible return and reintegration of FTFs and other persons who traveled to the Middle East to join ISIS continued its work in 2019.

Trinidad and Tobago institutions have demonstrated the capability to detect, deter, and prevent acts of terrorism with the assistance of international partners. The Trinidad and Tobago Police Service (TTPS), including its Special Branch, Special Investigations Unit, and Financial Investigations Branch, is the law enforcement agency with primary responsibility for investigating terrorism and terrorism finance cases. Trinidad and Tobago's Strategic Services Agency, Defense Force, Prison Service, Immigration Division, Customs and Excise Division, and the Financial Intelligence Unit support the TTPS' activities. The TTPS has conducted vulnerability risk assessments of soft targets and national critical infrastructure.

Trinidad and Tobago continues to collect and analyze API and requires commercial air carriers to transmit information on all passengers and crew members on inbound flights and certain outbound flights to the Joint Regional Communications Center operated by the Caribbean Community's (CARICOM) Implementation Agency for Crime and Security. According to the Trinidad and Tobago government, it also maintains a national watchlist of persons of interest to national security, which can include persons suspected of engaging in terrorist activity. The Trinidad and Tobago Coast Guard increased patrols of its southern maritime border, which is less than 10 miles from the coast of Venezuela.

The Trinidad and Tobago Prison Service created a high-risk management unit in 2018 that was designated in 2019 as the primary unit responsible for dealing with any FTFs should they be incarcerated upon their return.

Countering the Financing of Terrorism: Trinidad and Tobago is a member of CFATF. Its FIU, the Financial Intelligence Unit of Trinidad and Tobago, is a member of the Egmont Group.

In October, the FATF made an initial determination that Trinidad and Tobago has substantially completed its action plan to address identified strategic deficiencies in its anti-money laundering AML/CFT regimes, subject to verification that implementation of these reforms has been sustained. 
Trinidad and Tobago passed legislation in 2019 requiring non-profit organizations (NPOs) to register with the government and subjecting these organizations to oversight by the FIU. The government also carried out a risk assessment of NPOs, including with respect to terrorism finance. Several government agencies conducted outreach and issued guidance in 2019 to regulated entities on their obligations regarding terrorism finance and persons sanctioned under the country's Anti-Terrorism Act. Trinidad and Tobago also passed legislation to allow for civil asset recovery and "unexplained wealth" orders, though a new agency must first be created before civil asset recovery is fully operational. The country also passed amendments to its Companies Act to compel more adequate and accurate beneficial ownership information.

Trinidad and Tobago continued in 2019 to list individuals and organizations domestically that have been designated under relevant UN terrorism-related sanctions regimes using the country's Anti-Terrorism Act. There have been no persons charged or prosecuted for terrorism financing to date, nor has the government identified and frozen the assets of any persons designated under either UN sanctions regimes or domestically. The Ministry of the Attorney General and Legal Affairs established an Anti-Terrorism Unit to manage designations and other functions of the Attorney General's Office pursuant to the country's Anti-Terrorism Act.

Countering Violent Extremism: The Trinidad and Tobago government completed the final draft of a national "Preventing and Countering Violent Extremism" plan; final government approval of the plan remains pending.

Trinidad and Tobago's National Crime Prevention Program continued its outreach to vulnerable communities in the country, and the TTPS increased its engagement with youth in high-risk areas through its use of youth clubs, sporting events, and partnerships with local NGOs.

In June, Trinidad and Tobago government representatives presented at a conference with leaders of the country's private sector as part of an effort to systematize funding for civil society organizations working on CVE issues. The Trinidad and Tobago government also spoke at and participated in a workshop in November with representatives from the country's Muslim community to encourage collaboration on a rehabilitation and reintegration plan for possible returning ISIS-affiliated Trinbagonian nationals.

International and Regional Cooperation: Trinidad and Tobago is a member of the OAS InterAmerican Committee against Terrorism. Trinidad and Tobago is also a member of CARICOM and is working with other CARICOM member states to implement a regional CT strategy adopted in 2018. 
Trinidad and Tobago has partnered with Hedayah, the Global Counterterrorism Forum, and the UK Commonwealth Secretariat, among others, to develop its national CVE plan. The UN is assisting the government's inter-ministerial committee to implement Trinidad and Tobago's national counterterrorism strategy; in September, the UN and Trinidad and Tobago announced the country will host a regional CT conference in 2020. The International Institute of Justice and Rule of Law has provided training to law enforcement officers, prosecutors, and others on developing terrorism-related cases.

The city of Chaguanas in Trinidad is a member of the SCN.

\section{VENEZUELA}

Overview: On January 10, 2019, Nicolás Maduro sought to begin an illegitimate second term as president, following 2018 presidential elections that were widely condemned as fraudulent. Juan Guaidó, as president of the National Assembly (AN), invoked the Venezuelan constitution on January 23 concerning vacancies in the Office of the President to assume the role of Interim President. Maduro and his associates use criminal activities to help maintain their illegitimate hold on power, fostering a permissive environment for known terrorist groups, including dissidents of the Revolutionary Armed Forces of Colombia (FARC-D), the Colombian-origin National Liberation Army (ELN), and Hizballah sympathizers. Financial ties with FARC-D, ELN, and Venezuelan paramilitary groups facilitate the public corruption and graft schemes of the regime to include members of the armed forces. Of concern, there were reports noting sporadic cooperation between FARC-D and ELN in the areas of road/border checkpoints, subsidized food distribution, recruitment and forced displacement of vulnerable indigenous communities, and trafficking of illegal narcotics and gold. According to local and international media, ELN was present in 12 of Venezuela's 24 states (with particular strength in Anzoátegui, Amazonas, Apure, Bolivar, Zulia, and Táchira states). The ELN's presence has expanded beyond its historic base in the border zone with Colombia. Media report an increasing role for the ELN in regime-subsidized food distribution, contraband (gas, basic goods, meat), extortion, illegal mining, and recruitment propaganda, at times via control of radio stations.

Interim President Guaidó condemned Maduro's complicity with the ELN and FARC-D. In October, he said that the former regime "promotes and protects terrorism, representing a risk for peace in the region." Within the same resolution, the AN officially designated the FARC-D, ELN, Hamas, Hizballah, and ISIS as terrorist organizations. Guaidó warned that Maduro has lost control of Venezuela's borders and territory, running the risk of turning Venezuela into a "failed state."

2019 Terrorist Incidents: Terrorist incidents in Venezuela reflected ELN's growing presence and territorial control. There were increased confrontations between ELN, other Colombian and Venezuelan illegal armed groups, and Venezuelan government forces.

Legislation, Law Enforcement, and Border Security: There were no changes to Venezuela's counterterrorism legislation in 2019. 
The former Maduro regime has not demonstrated political will to address terrorism concerns in Venezuela. The regime's usurpation of the judicial system and military/security services for its own illicit ends, rampant public corruption, and cooperation with criminal elements provided ideal conditions for illegal activity. The regime's economic mismanagement has created dire resource constraints. The regime regularly uses charges of terrorism to persecute the political opposition and suppress dissent. It has accused without evidence or due process Guaidó's Chief of Staff and multiple AN deputies of "terrorism."

Systematic corruption plagues the issuance of Venezuelan passport and identification documents. In December 2019, the United States sanctioned the current and former directors of Venezuela's passport agency (Administrative Service of Identification, Migration, and Immigration) in light of activities such as the agency's sales of passports for thousands of dollars, including to nonVenezuelan citizens. Border security at ports of entry was vulnerable and susceptible to corruption. Biometric screening is not conducted at Venezuelan ports of entry. There is no automated system to collect API or PNR records on commercial flights or to crosscheck flight manifests with passenger disembarkation data.

Countering the Financing of Terrorism: Venezuela is a member of the CFATF. Venezuela's FIU, the National Financial Intelligence Unit, is a member of the Egmont Group. There were no significant updates in 2019.

Countering Violent Extremism: There were no CVE efforts underway in 2019.

International and Regional Cooperation: The Guaidó government worked with regional partners to invoke the Interamerican Treaty of Reciprocal Assistance (also known as the Rio Treaty) in September to address the former Maduro regime's illegal activities, including terrorism and its financing. Guaidó pledged to work closely with Colombian President Duque on the regional threat posed by ELN, FARC-D, and other illegal armed actors in Venezuela. 


\section{Chapter 2: State Sponsors of Terrorism}

This report provides a snapshot of events during 2019 relevant to countries designated as State Sponsors of Terrorism. It does not constitute a new announcement regarding such designations.

To designate a country as a State Sponsor of Terrorism, the Secretary of State must determine that the government of such country has repeatedly provided support for acts of international terrorism. Once a country is designated, it remains a State Sponsor of Terrorism until the designation is rescinded in accordance with statutory criteria. A wide range of sanctions is imposed as a result of a State Sponsor of Terrorism designation, including:

- A ban on arms-related exports and sales;

- Controls over exports of dual-use items, requiring 30-day Congressional notification for goods or services that could significantly enhance the terrorist-list country's military capability or ability to support terrorism;

- Prohibitions on economic assistance; and

- Imposition of miscellaneous financial and other restrictions.

\section{DEMOCRATIC PEOPLE'S REPUBLIC OF KOREA}

On November 20, 2017, the Secretary of State designated the Democratic People's Republic of Korea (DPRK) as a State Sponsor of Terrorism. The Secretary determined that the DPRK government repeatedly provided support for acts of international terrorism, as the DPRK was implicated in assassinations on foreign soil.

The DPRK was previously designated as a State Sponsor of Terrorism in 1988 primarily because of its involvement in the bombing of a Korean Airlines passenger flight in 1987. The DPRK's designation was rescinded in 2008 after a thorough review found the DPRK met the statutory requirements for rescission. In 2017, the Secretary of State determined the DPRK had repeatedly provided support for acts of international terrorism since its State Sponsor of Terrorism designation was rescinded in 2008. The DPRK has also failed to take action to address historical support for acts of international terrorism. Four Japanese Red Army members wanted by the Japanese government for participating in a 1970 Japan Airlines hijacking continue to shelter in the DPRK. The Japanese government also continues to seek a full accounting of the fate of a number of Japanese nationals believed to have been abducted by DPRK state entities in the 1970s and 1980s; only five such abductees have been repatriated to Japan since 2002.

\section{IRAN}

Designated as a State Sponsor of Terrorism in 1984, Iran continued its terrorist-related activity in 2019, including support for Hizballah, Palestinian terrorist groups in Gaza, and various terrorist groups in Syria, Iraq, and throughout the Middle East. Iran used the Islamic Revolutionary Guard Corps-Qods Force (IRGC-QF) to provide support to terrorist organizations, provide cover for associated covert operations, and create instability in the region. Iran has acknowledged the involvement of the IRGC-QF in the Iraq and Syria conflicts, and the IRGC-QF is Iran's primary 
mechanism for cultivating and supporting terrorists abroad. In April 2019, the Secretary of State designated the IRGC, including the Qods Force, as a Foreign Terrorist Organization (FTO). Iran also used regional proxy forces to provide deniability, in an attempt to shield it from accountability for its aggressive policies.

In 2019, Iran supported various Iraqi Shia terrorist groups, including Kata'ib Hizballah (KH), Harakat al-Nujaba, and Asa'ib Ahl al-Haq. During the same period, KH was responsible for a series of rocket attacks against American interests in Iraq, which culminated in the death of an American citizen following a 30 plus rocket barrage in December 2019. On December 31, Iran-backed Shia militia groups, including KH, participated in an attack on U.S. Embassy Baghdad, which resulted in significant damage to embassy property. There were no embassy casualties and security personnel used less-than-lethal countermeasures to repulse intruders. It also bolstered the Assad regime in Syria and Shia terrorist groups operating there, including Hizballah. Iran views the Assad regime in Syria as a crucial ally and Syria and Iraq as vital routes through which to supply weapons to Hizballah, Iran's primary terrorist proxy group. Through financial or residency enticements, Iran has facilitated and coerced primarily Shia fighters from Afghanistan and Pakistan to participate in the Assad regime's brutal crackdown in Syria. Iran-supported Shia militias in Iraq have also committed serious human rights abuses against primarily Sunni civilians. Iranian forces have directly backed militia operations in Syria with armored vehicles, artillery, and drones.

Since the end of the 2006 Israeli-Hizballah conflict, Iran has supplied Hizballah with thousands of rockets, missiles, and small arms in direct violation of UNSCR 1701. Israeli security officials and politicians expressed concerns that Iran was supplying Hizballah with advanced weapons systems and technologies, as well as assisting the group in creating infrastructure that would permit it to indigenously produce rockets and missiles to threaten Israel from Lebanon and Syria. Iran has provided hundreds of millions of dollars in support of Hizballah and trained thousands of its fighters at camps in Iran. Hizballah fighters have been used extensively in Syria to support the Assad regime. In Bahrain, Iran has continued to provide weapons, support, and training to local Shia militant groups, including the al-Ashtar Brigades. In Yemen, Iran has provided weapons, support, and training to the Houthi militants, who have engaged in terrorist attacks against regional targets.

In 2019, Iran provided support to Hamas and other designated Palestinian terrorist groups, including Palestine Islamic Jihad and the Popular Front for the Liberation of Palestine-General Command. These Palestinian terrorist groups were behind numerous deadly attacks originating in Gaza and the West Bank, including attacks against Israeli civilians in the Sinai Peninsula.

The Iranian government maintains a robust offensive cyber program and has sponsored cyber attacks against foreign government and private sector entities.

Iran remained unwilling to bring to justice senior al-Qa'ida (AQ) members residing in the country and has refused to publicly identify members in its custody. Iran has allowed AQ facilitators to operate a core facilitation pipeline through Iran since at least 2009, enabling AQ to move funds and fighters to South Asia and Syria. 
As in past years, the Iranian government continued supporting terrorist plots to attack Iranian dissidents in several countries in continental Europe. In recent years, the Netherlands, Belgium, and Albania have all either arrested or expelled Iranian government officials implicated in various terrorist plots in their respective territories. Denmark similarly recalled its ambassador from Tehran after learning of an Iran-backed plot to assassinate an Iranian dissident in its country.

\section{SUDAN}

The Secretary of State designated Sudan as a State Sponsor of Terrorism in 1993 for supporting international terrorist groups, including the Abu Nidal Organization, Palestine Islamic Jihad, Hamas, and Hizballah. In September 2019, Sudan officially formed the civilian-led transitional government (CLTG) after 30 years under the regime of former President Omar al-Bashir. The CLTG has asserted that it no longer supports the aforementioned or any other terrorist organization. Sudan has taken steps to work with the United States on counterterrorism. Throughout 2019, despite political turmoil that led to the ouster of the former president and the formation in September of the CLTG, the Sudanese government continued to pursue counterterrorism operations alongside regional partners, including operations to counter threats to U.S. interests and personnel in Sudan.

Despite the absence of high-profile terrorist attacks, ISIS facilitation networks appear to be active within Sudan. The newly appointed Minister of Religious Affairs and Endowments under the CLTG denied the existence of an official ISIS entity in Sudan but acknowledged that there were "extremists" linked to ISIS in the country. The Minister of Religious Affairs and Endowments also emphasized that his ministry would work on combating extremism, fighting terrorism and renewing school curricula to promote tolerance. The media reported in November 2019 that the CLTG was prepared to return between 16 and 20 terrorists from ISIS and other groups to their countries of origin. The arrested persons belonged to different nationalities, including six Egyptians, one Tunisian, and six individuals from Chad and Nigeria.

As part of the government's counterterrorism strategy, Sudanese forces patrol the Sudanese-Libyan border as well as the Sudanese-Chadian border to interdict the flow of suspected terrorists transiting through the region, and to prevent arms smuggling and other illicit activities. Sudan's expansive size, and the government's outdated technology and limited visa restrictions, presented challenges for border security. The CLTG has asked for assistance from the U.S. government as well as the international community to upgrade its technical and physical capabilities to secure its borders.

Regarding AML/CFT, Sudan remains a member of the Middle East and North Africa Financial Action Task Force (MENAFATF), a Financial Action Task Force-style regional body. The Financial Action Task Force (FATF) and MENAFATF have both determined that Sudan's AML/CFT regime adequately addresses AML/CFT. Additionally, Sudan's Financial Information Unit is a member of the Egmont Group and works regularly with other members of the group on AML/CFT issues. 
While new, the CLTG continues to develop a national strategy for countering terrorist radicalization and recruitment. Sudan's existing strategy combines government and civil society resources and uses a social, economic, and religious approach toward strengthening Sudan's population against internal or external "extremist” influences. Sudan's de-radicalization programs run concurrently with the national strategy. De-radicalization programs in Sudan focused on reintegrating and rehabilitating returned FTFs and those espousing terrorist ideologies. Sudan repatriated a small number of women and children who are or had been affiliated with FTFs, mostly the spouses and children of ISIS members killed in Libya, and enrolled them in Sudanese rehabilitation programs.

\section{SYRIA}

Designated in 1979 as a State Sponsor of Terrorism, Syria continued its political and military support to various terrorist groups. The regime continued to provide weapons and political support to Hizballah and continued to allow Iran to rearm and finance the terrorist organization. The Assad regime's relationship with Hizballah and Iran grew stronger in 2019 as the regime became more reliant on external actors to fight opponents and secure areas. The Islamic Revolutionary Guard Corps (IRGC) remains present and active in the country with the permission of President Bashar al-Assad. Assad remained a staunch defender of Iran's policies, while Iran exhibited equally energetic support for the Syrian regime. Syrian government speeches and press releases often included statements supporting terrorist groups, particularly Hizballah and vice versa.

Over the past two decades, the Assad regime's permissive attitude towards AQ and other terrorist groups' FTF facilitation efforts during the Iraq conflict fed the growth of AQ, ISIS, and affiliated terrorist networks inside Syria. The Syrian government's awareness and encouragement for many years of terrorists' transit through Syria to Iraq for the purpose of fighting U.S. forces before 2012 is well documented. Those very networks were among the terrorist elements that brutalized the Syrian and Iraqi populations in 2019. Additionally, Shia militia groups in Iraq, some of which are U.S.-designated FTOs aligned with Iran, continued to travel to Syria to fight on behalf of the Assad regime. Marxist groups, including affiliates of the Kurdistan Workers' Party (PKK), also operated on Syrian soil and represent Turkey's primary counterterrorism concern in Syria. ISIS cells remained active in parts of Syria and launched attacks on civilians and U.S. partner forces. In October, U.S. forces completed an operation that resulted in the death of ISIS leader al-Baghdadi. ISIS members in Syria continued to plot or inspire external terrorist operations.

As part of a broader strategy during the year, the regime portrayed Syria itself as a victim of terrorism, characterizing all internal armed opposition as "terrorists." 


\section{Chapter 3: The Global Challenge of Chemical, Biological, Radiological, or Nuclear Terrorism}

The use of chemical, biological, radiological, and nuclear (CBRN) materials and expertise remained a terrorist threat in 2019. The United States published a National Strategy for Countering Weapons of Mass Destruction (WMD) Terrorism in 2018 and continues to work proactively to disrupt and deny ISIS and other nonstate actors' CBRN capabilities.

The international community has established numerous international partnerships to counter the CBRN threat from terrorists and other nonstate actors. The United States routinely provides technical and financial assistance and training to partner nations and international organizations to help strengthen their abilities to adequately protect and secure CBRN-applicable expertise, technologies, and material.

The Global Partnership Against the Spread of Weapons and Materials of Mass Destruction (GP) was launched in 2002 to prevent terrorists - or states that support them - from acquiring or developing WMD. Today, the GP has expanded its membership to 30 countries and the European Union and remains a vital forum for countries to exchange information on national priorities for CBRN programmatic efforts worldwide and coordinate assistance for these efforts.

The United States continues to support the International Atomic Energy Agency (IAEA) Division of Nuclear Security, which helps member states develop the capacity to prevent, detect, and respond to threats of nuclear terrorism through the development of guidance as well as the provision of training, technical advice, peer reviews, and other advisory services.

The Global Initiative to Combat Nuclear Terrorism (GICNT) is an international partnership of 89 nations and six official observer organizations dedicated to strengthening global capacity to prevent, detect, and respond to a nuclear terrorist incident. In 2019, partner nations hosted eight multilateral activities that raised awareness of the threat of terrorist use of nuclear and radioactive materials and provided opportunities for countries to share information, expertise, and best practices in a voluntary, nonbinding framework.

Through the Global Threat Reduction Program (GTR), the Department of State continued its work to prevent states and terrorist groups from acquiring or proliferating WMD to attack the United States. In 2019, the GTR's chemical, biological, and nuclear security programs implemented more than one hundred capacity building projects to ensure that foreign partners could detect and counter WMD terrorism threats. To ensure the enduring defeat of ISIS, the GTR continued training and equipping Iraqi counterterrorism and security forces to detect and respond to WMD attacks and supported Iraqi partners in formerly ISIS-controlled territory to secure weaponizable chemical and biological materials to prevent future WMD attacks. In response to the threat of transnational terrorists conducting chemical weapons $(\mathrm{CW})$ attacks using unrestricted, commercially available material, the GTR collaborated with security forces around the world to train law enforcement in partner countries to detect and prevent $\mathrm{CW}$ attacks against vulnerable transportation hubs, such as railways and subways. 
To help partner countries intercept foreign terrorist fighters (FTFs) attempting to carry out WMD plots, the GTR continued to partner with international law enforcement organizations to augment an existing FTF law enforcement database with WMD-applicable information, and trained partner countries to help populate the database and use the information to interdict WMDcapable FTFs. The GTR also worked with personnel from Egypt, Jordan, Libya, Nigeria, the Philippines, and other countries to promote the adoption of security measures to prevent individuals or nonstate actors from acquiring potentially weaponizable chemical, biological, and nuclear material and technology.

The Department of State's Export Control and Related Border Security (EXBS) Program funds capacity building programs aimed at strengthening legal and regulatory systems, developing licensing tools, enhancing border security and trade enforcement, providing outreach to key industrial and business sectors, and encouraging the sharing of information within governments and across national borders. As part of a core national security strategy to combat ISIS and other terrorist organizations, a key objective of the EXBS Program is to provide substantive knowledge, skills, and tools to prevent state and nonstate actors from acquiring WMD, conventional arms, and explosives or using those materials against U.S. citizens and interests. To achieve this objective, EXBS continued to train partner governments in the Middle Eastern and North African regions to detect, interdict, and counter the materials, technologies, and tactics that terrorists could use to carry out low-technology attacks on public transportation.

Additionally, in 2019, EXBS began development of curriculum for partner nation security forces to address threats posed by improvised threats. EXBS also provided comprehensive training to Middle East and North African border security officials on border security, cargo and passenger interdiction, and counter-IED training. EXBS partnered with CT and the interagency to engage with key partners on aviation security programming. Finally, EXBS furnished equipment and training to strengthen aviation security and mitigate threats to civilian aviation, and refurbished border security infrastructure - including at Rabia, on Iraq's border with Syria - to stem the flow of illicit materials and maintain gains made against ISIS.

At a special session held in 2018, the Organization for the Prohibition of Chemical Weapons (OPCW) Conference of the States Parties adopted a decision titled "Addressing the Threat From Chemical Weapons Use" that provides the OPCW's Technical Secretariat with additional tools to respond to chemical weapons use, including by nonstate actors. This landmark decision helps guide the work of OPCW in deterring chemical weapons use and responding if they are used. Specifically, the OPCW now has an Investigation and Identification Team that is working to identify the perpetrators of CW use in Syria. The OPCW is considering options for further assistance to States Parties to help prevent the chemical weapons threat posed by nonstate actors and to aid contingency planning of States Parties in the event of a chemical weapons attack. Through the Department's Nonproliferation and Disarmament Fund, the Administration provided funding to support the OPCW's Technical Secretariat special missions and contingency operations related specifically to Syria through the OPCW's "Trust Fund for Syria Missions." 


\section{Chapter 4: Terrorist Safe Havens (Update to 7120 Report)}

Terrorist safe havens described in this report include ungoverned, under-governed, or ill-governed physical areas where terrorists are able to organize, plan, raise funds, communicate, recruit, train, transit, and operate in relative security because of inadequate governance capacity, political will, or both.

As defined by section 2656f(d) of Title 22 of the U.S. Code, the terms "terrorist sanctuary" and "sanctuary" exclude the territory of a country the government of which is subject to a determination under section 4605(j)(1)(A) of Title 50 [deemed under Section 1768(c)(2) of the National Defense Authorization Act of Fiscal Year 2019 (NDAA FY19) to refer to section 1754(c) of the NDAA FY19 as of August 13, 2018]; section 2371(a) of Title 22; or section 2780(d) of Title 22. (For information regarding the Democratic People's Republic of Korea, Iran, Sudan, and Syria, see Chapter 2, State Sponsors of Terrorism.)

\section{TERRORIST SAFE HAVENS}

\section{AFRICA}

Somalia. In 2019, terrorists used under-governed areas throughout Somalia as safe havens to plan, conduct, and facilitate operations within Somalia, including mass-casualty bombings in major urban areas, and attacks in neighboring countries. The Federal Government of Somalia's Comprehensive Approach to Security partnership with the international community includes military, law enforcement, and CVE-specific "strands" to ameliorate Somalia's security challenges at the federal, state (federal member state), and local levels. Somali law enforcement took several actions in 2019 that led to prosecutions of individuals suspected of terrorism-related activities. However, Somali officials failed to implement vital national security reforms and pass legislation that could help enhance the government's capacity to secure and govern effectively at all levels. Despite these critical gaps in its counterterrorism strategy, the Somali government remained a committed partner and vocal advocate for U.S. counterterrorism efforts.

With the notable exception of targeted operations carried out by U.S.-trained and -equipped units of Somali military forces, the Somali National Army as a whole remained incapable of independently securing and retaking towns from al-Shabaab. This critical gap allowed al-Shabaab to continue to extort local populations and forcibly recruit fighters, some of whom were children.

As seen in previous years, al-Shabaab kept some of its safe haven in the Jubba River Valley as a primary base of operations for plotting and launching attacks. The group retained control of several towns throughout the Jubaland region, including Jilib and Kunyo Barow, and maintained operations in the Gedo region to exploit the porous Kenya-Somalia border and attack targets in Kenya. The Kenyan government maintains a strong presence throughout the border region. In northern Somalia, ISIS-linked fighters used the limited safe haven they established in Puntland to launch small-scale attacks. 
Somalia remained heavily dependent on regional and international partners to support almost all major security functions throughout the country, making little progress on improving interagency coordination to limit terrorist transit through the country.

According to independent sources and non-governmental organizations engaged in demining activities on the ground, there was little cause for concern regarding the presence of WMD in Somalia.

The Lake Chad Region. In 2019, Boko Haram (BH) and ISIS-West Africa (ISIS-WA) maintained limited safe havens in parts of northeast Nigeria and on islands in Lake Chad, and they prevented the reestablishment of state administration, service delivery, and humanitarian relief in broader territory surrounding Lake Chad. These safe havens are reduced from the territory BH controlled in 2014-2015. Forces from Nigeria and other members of the Multinational Joint Task Force (Benin, Cameroon, Chad, and Niger) lack the capability to clear these safe havens, and they lack the capacity and resources to secure borders and hold and administer liberated territory. Both BH and ISIS-WA continued to conduct asymmetric attacks against civilians, military, and government personnel, including through suicide bombers, VBIEDs, raids, ambushes, kidnappings, and other means. As a result of this insecurity, at year's end more than 2.6 million people in the Lake Chad Region remained displaced and millions more remain dependent on humanitarian assistance.

No government in the Lake Chad Region was known to support or facilitate the proliferation or trafficking of WMD in or through its territory.

The Trans-Sahara. In 2019, al-Qa'ida affiliate Jamaat Nusrat al-Islam wal-Muslimin (JNIM), and other groups, including Ansural Islam and ISIS in the Greater Sahara (ISIS-GS), continued to stage asymmetric attacks in the Trans-Sahara region. In addition to asymmetric attacks, these groups perpetrated a series of large-scale conventional attacks on both patrols and fixed positions of regional Armed Forces. These terrorist groups have freedom of movement in northern and central Mali, northern Burkina Faso, along the Mali-Niger border, and along both sides of the Burkina Faso/Niger border, demonstrated by their ability to quickly mass forces during the large-scale attacks seen this year. JNIM successfully inserted itself into long-standing ethnic conflicts such as the Fulani herder versus Dogon farmer conflict over grazing land and water.

The Malian government struggles to combat these terrorists, notwithstanding the presence of the UN peacekeeping mission, Multidimensional Integrated Stabilization Mission in Mali (MINUSMA), and a French presence in the region consisting of 4,500 military members. In Burkina Faso, the government has failed to stem the tide of violence; attacks increased significantly in 2019 compared to 2018. The end of 2019 in Niger was marked by the largest casualty producing attack on the Nigerien Army to date. On December 11, the Nigerien Army lost over 70 soldiers at a remote base in the Tillaberi region near the Malian border in an attack that was claimed by ISIS-GS. There has been a significant influx of Western aid as part of the effort to increase the capacity of the G-5 Sahel Joint Force, of which Burkina Faso is a member. Niger and Chad continue to combat terrorism on their borders. Mauritania has not experienced a terrorist attack since 2011. 
No government in the region was known to support or facilitate the proliferation or trafficking of WMD in or through its territory, although the region remained prone to arms and munitions smuggling.

\section{SOUTHEAST ASIA}

The Sulu/Sulawesi Seas Littoral. The Government of Indonesia conducts monitoring and surveillance of suspected terrorist cells in its territory, but acknowledges that a lack of resources hinders its ability to monitor maritime and remote parts of Indonesia, including the Sulu and Sulawesi Seas. In 2019, the Indonesian, Malaysian, and Philippines' militaries continued coordinated patrols in the Sulu and Sulawesi Seas to deter and prevent kidnapping and terrorist transit in their adjoining exclusive economic zones. The first trilateral land exercise occurred in North Kalimantan in July 2019. Indonesia's Counterterrorism Agency (BNPT) hosted a bilateral counterterrorism workshop with the United States on September 4-5 to build capacity for various Indonesian agencies in preventing and countering terrorist activities in border areas and outer islands. The workshop was the first under the auspices of the 2018 U.S.-Indonesia Memorandum of Understanding on Counterterrorism.

The Government of Malaysia sustained efforts to counter terrorist use of the Sulu/Sulawesi Seas as a safe haven by working with Indonesia and the Philippines to prevent the flow of FTFs through its territory. The Royal Malaysian Police special forces unit 69 Komando, which focuses on counterterrorism, search and rescue, and counterinsurgency, participated in a crisis response training exercise in August with U.S. Indo-Pacific Command to build capacity on addressing extended hostage rescue scenarios.

The Southern Philippines. The Philippine government closely tracked terrorist groups that continue to operate in some areas, particularly in the southern Philippines. The government sustained aggressive military and law enforcement operations to deny safe haven to such groups and prevent the flow of FTFs through its territory. The government further deepened close counterterrorism cooperation with the United States, enhancing military and law enforcement efforts to address the full spectrum of terrorist threats, including from WMD. The government welcomed support from the U.S. Defense Threat Reduction Agency in 2019 to help reduce the risk of nonstate actors acquiring or using improvised chemical weapons.

International reconstruction assistance focused on Marawi continued, but concerns remained that efforts are not including local stakeholders and adjudicating competing land claims - both factors that terrorists can exploit.

Although the Philippine government possesses the political will to apply security measures against terrorist threats and has consistently partnered with the United States and other nations to build the capacity to do so, it struggles to apply a coordinated whole-of-government approach to prevent terrorism. The continued ability of terrorist organizations to operate in the southern Philippines reflects the centuries-long challenge of governing effectively in the country's more remote areas and establishing consistent security in a region characterized by a strong separatist identity, endemic poverty, and religious differences. 


\section{THE MIDDLE EAST AND NORTH AFRICA}

North Sinai. In 2019, ISIS-Sinai Province (ISIS-SP) used portions of Egypt's Sinai region as a base to conduct attacks against military and civilian targets in the Sinai, though they claimed no attacks in mainland Egypt. Between January and December, 428 significant conflict events occurred in Northern Sinai, including 134 IED-related attacks, 153 airstrikes, and near weekly complex assaults on government fortified positions by ISIS-SP. These events have exemplified ISIS-SP's freedom to maneuver during daytime hours and the expansion of its attacks westward, toward the Suez Canal Zone, and southward. In April, ISIS-SP responded to the call to avenge ISIS's territorial defeat in Syria by increasing attacks globally. In addition, ISIS-SP was the first ISIS affiliate to swear allegiance to the new ISIS self-proclaimed caliph.

While Egypt's most recent large-scale campaign against ISIS-SP, "Operation Sinai 2018," ended, counterterrorism operations in Sinai continued. Egypt continued to partner with U.S. counterterrorism efforts in this regard and continued its measures to prevent the proliferation and trafficking of WMD. At the same time, the Government of Egypt, including the Egyptian Armed Forces, broadened its counterterrorism strategy in Sinai to encompass development and humanitarian projects on the peninsula. ISIS-SP has continued to carry out attacks, and Egyptian security forces face frequent small arms and IED attacks. These repeated attacks indicate that ISIS-SP remains intent on expanding its influence and operations in the Sinai.

The United States supported Egypt's efforts to combat ISIS-SP and other terrorist groups in Egypt by providing AH-64 Apache helicopters, mine-resistant and ambush-protected vehicles, counter-IED training, mobile sensor towers, and border security training programs. The United States routinely engages in military-to-military discussions on how it can help Egypt defeat ISIS-SP and other terrorist groups in Egypt. The United States remains concerned about the security situation in Sinai and the potential effects on the Multinational Force and Observers peacekeeping mission located there.

Iraq. Iran-backed Kata'ib Hizballah (KH), a designated FTO, continued to maintain an active presence in Iraq targeting U.S., Coalition, and Iraqi forces. On December 27, KH launched a rocket attack on an Iraqi military base near Kirkuk, killing an American civilian contractor and wounding several U.S. military service members and Iraqi personnel. In response, on December 29, the United States carried out military strikes in Iraq and Syria targeting KH. On December 31, Iran-backed terrorists attacked the U.S. Embassy in Baghdad, resulting in no casualties but damaging the embassy exterior.

Supported by the 81-member Global Coalition to Defeat ISIS, the Government of Iraq maintained nominal control of the territory retaken from ISIS in 2019. ISIS remained a terrorist threat in Iraq in 2019, carrying out suicide, hit-and-run, and other asymmetric attacks throughout the country. The United States continued to engage with the Government of Iraq to deny ISIS access to CBRN materials. The United States worked to strengthen the expertise and ability of Iraq's government, academic institutions, and private sector to secure weaponizable chemical and biological materials and to detect, disrupt, and respond effectively to suspected CBRN activity. This included providing CBRN detection, analysis, and investigation training at internationally recognized training centers of excellence, such as the Defense CBRN Center in 
Vught, Netherlands, and the National Institute for Nuclear, Chemical, and Biological Protection in the Czech Republic. The United States and Iraq also continued their bilateral partnership to counter nuclear smuggling under the framework of the 2014 Joint Action Plan on Combating Nuclear and Radioactive Materials Smuggling.

Lebanon. Lebanon remained a safe haven for terrorist groups in Hizballah-controlled areas. Hizballah used these areas for terrorist training, fundraising, financing, and recruitment. The Government of Lebanon did not take actions to disarm Hizballah, which continued to maintain its weapons without the consent of the Lebanese government, contrary to UNSCR 1701. The Lebanese government did not have complete control of all regions of the country or fully control its borders with Syria and Israel. Hizballah controlled access to parts of the country and had influence over some elements within Lebanon's security services

Al-Nusrah Front, ISIS, and other Sunni terrorist groups also continued to operate in ungoverned areas along the un-demarcated Lebanese-Syrian border in 2019. The Lebanese government continued to take action to curtail these groups' activities. Other terrorist groups, including Hamas, the Popular Front for the Liberation of Palestine, the Popular Front for the Liberation of Palestine General Command, Asbat al-Ansar, Fatah al-Islam, Fatah al-Intifada, Jund al-Sham, Palestinian Islamic Jihad, and the Abdullah Azzam Brigades, continued to operate with limited government control within Lebanon primarily inside Lebanon's 12 Palestinian refugee camps. These groups used the Palestinian camps as safe havens to house weapons, shelter wanted criminals, and plan terrorist attacks.

The United States worked closely with the Lebanese Armed Forces (LAF) and Internal Security Forces to counter terrorist threats within Lebanon and along its border with Syria by providing counterterrorism training, military equipment, and weaponry.

Lebanon was not a source country for WMD components, but its porous border with Syria posed risks for the spread of WMDs. In 2019, the LAF and other security services partnered with U.S. government agencies to detect and prevent proliferation and trafficking of WMDs.

Libya. Conflict continued during the year between the Government of National Accord (GNA) and Libyan National Army (LNA)-aligned groups and other nonstate actors, including terrorist groups. Through most of 2019, GNA-aligned groups maintained control of most of Greater Tripoli, the Western Mountains, and the northwest coastal areas stretching from the Tunisian border to Sirte. LNA-aligned groups controlled the remainder of Libya, including Cyrenaica, and increased their presence in the central and southern districts of Jufra, Kufra, Sabha, and Murzuq. Libya's vast, sparsely populated desert areas, particularly in central and southern Libya, remain safe havens for al-Qa'ida in the Islamic Maghreb and the Islamic State of Iraq and the Levant-Libya (ISIL-Libya). The GNA, although the internationally recognized government, lacked the capacity and reach to project authority into most of Libya and relied on militias and other armed groups for security in areas it does not have the ability to effectively control. The GNA had limited ability to eliminate terrorist safe havens, prevent the flow of FTFs, or ensure effective counter-proliferation efforts. U.S. airstrikes conducted in coordination with the GNA applied pressure to ISIL-Libya networks in Libya during 2019. Because of the difficulties of controlling the southern and desert borders and a lack of respect for security 
procedures at air and seaports of entry by foreign state or Libyan substate groups, the GNA remained unable to effectively track flows of FTFs in and out of its territory. During the year, the European Union Agency for Law Enforcement Cooperation (Europol) warned that terrorist groups attempted to reach Libya following the collapse of ISIS's territorial caliphate in the Levant. On March 6, security services of Bosnia and Herzegovina released a statement indicating that Nusret Imamovic, a U.S.-designated terrorist under Executive Order 13224, had travelled to Libya in February after having fled Syria where he had fought with al-Nusrah Front since 2013. Rival factions and political stakeholders outside of the GNA, including in the LNA-aligned forces, were also unable to stem the flow of FTFs.

Yemen. Iran-backed Houthi militants controlled large portions of northern Yemen, where the Islamic Revolutionary Guard Corps (IRGC) continued to maintain a presence. Saudi Arabia and the United Arab Emirates (UAE) supported the Republic of Yemen Government which continued to fight to reclaim territory held by Iran-backed Houthi militants. The Republic of Yemen Government, with the support of the Saudis and Emiratis, continued counterterrorism operations to deny al-Qa'ida in the Arabian Peninsula (AQAP) and ISIS-Yemen safe haven in the country. The northwest of the country, as well as portions of the southern coast interior, are beyond Republic of Yemen Government control, severely constraining its ability to prevent terrorist training, funding, recruitment, and transit. Although AQAP and ISIS-Yemen have been degraded in recent years, the two groups continued to benefit from the ongoing conflict with the Houthis, successfully instilling themselves among elements of the anti-Houthi coalition and exploiting the security vacuum in large parts of the country. Under President Hadi's leadership, the Republic of Yemen Government has been as cooperative with U.S., Saudi, and UAE counterterrorism operations as its limited capacity will allow. In 2019, the UAE began retrograding portions of its forces from Yemen.

Yemen's political instability continued to hinder efforts to enact or enforce comprehensive strategic trade controls to counter the flow of weapons and munitions in the region. This left Yemen vulnerable as a transit point for destabilizing weapons, including weapons emanating from Iran.

\section{SOUTH ASIA}

Afghanistan. Terrorist and insurgent groups exploit Afghanistan's ungoverned spaces, including the border region of Afghanistan and Pakistan. Islamic State's Khorasan Province (ISIS-K), elements of al-Qa'ida, including affiliate al-Qa'ida in the Indian Subcontinent (AQIS), and terrorist groups targeting Pakistan, such as Tehrik-e-Taliban Pakistan, continued to use the Afghanistan-Pakistan border region as a safe haven. Despite progress against ISIS-K in late 2019, the Government of National Unity (GNU) struggled to assert control over this remote terrain, where the population is largely detached from national institutions. U.S. and Afghan security forces partnered in numerous counterterrorism operations against ISIS-K and AQIS, including an operation in September, which eliminated AQIS leader Asim Umar in Helmand province.

The potential for WMD trafficking and proliferation remained a concern. In 2019, the United States and Afghanistan continued to work to finalize a bilateral framework to help 
Afghanistan enhance its capabilities to prevent, detect, and respond to nuclear and other radioactive material smuggling incidents. The Afghanistan and U.S. governments also continued to work to implement comprehensive strategic trade controls and strengthen Afghanistan's border security.

Pakistan. Although Pakistan's National Action Plan calls to "ensure that no armed militias are allowed to function in the country," several terrorist groups that focus on attacks outside the country continued to operate from Pakistani soil in 2019, including the Haqqani Network, Lashkar-e-Tayyiba, and Jaish-e-Mohammed. The government and military acted inconsistently with respect to terrorist safe havens throughout the country. Authorities did not take sufficient action to stop certain terrorist groups and individuals from openly operating in the country.

Pakistan is committed to combating the trafficking of items that could contribute to the development of WMDs and their delivery systems. Pakistan was a constructive and active participant in International Atomic Energy Agency-hosted meetings and in the Global Initiative to Combat Nuclear Terrorism (GICNT).

\section{WESTERN HEMISPHERE}

Colombia. Rough terrain and dense forest cover, coupled with low population densities and historically weak government presence, define Colombia's borders with Brazil, Ecuador, Peru, and Venezuela. Historically these conditions have allowed terrorist groups to operate, particularly Revolutionary Armed Forces of Colombia (FARC) dissidents and the National Liberation Army (ELN). The peace accord between the Government of Colombia and FARC in 2016 led to a normalization of relations, with the latter entering the political sphere.

However, ongoing challenges to peace accord implementation and continued security vacuums have created risk for terrorist activity and attacks on civilians, security forces, and infrastructure in some areas in 2019. A troubling number of FARC dissidents, estimated at around 2,600 individuals who chose not to participate in the peace process or have since abandoned the peace process, continued engaging in terrorist and other criminal activities, particularly in border regions and areas previously controlled by the FARC.

The ELN perpetrated armed attacks across the country in 2019. In January, the ELN detonated a car bomb inside Colombia's national police academy, killing 22 cadets and injuring 87 others. President Duque suspended peace talks with the ELN after assuming office in August 2018, then ended them after the January 2019 attack.

Improved relations with neighboring Ecuador have led to some increased cooperation on law enforcement issues. Colombia also continued to cooperate and share information with the Panamanian National Border Service. Additionally, the Government of Colombia cooperated with Brazil to address potentially problematic areas along their shared borders, while Brazil continued efforts to implement its Integrated Border Monitoring System to monitor its entire border. 
Cuba. Cuba, citing peace negotiation protocols, refused Colombia's request to extradite ten ELN leaders living in Havana after that group claimed responsibility for the January 2019 bombing of the national police academy in Bogota, killing 22 people and injuring 87. On October 11, Colombia filed extradition requests for ELN leaders Victor Orlando Cubides aka "Pablo Tejada" and Isreal Ramirez Pineda aka "Pablo Beltran" with the Cuban government, which has pointedly not responded. In addition to ELN terrorists, there was credible reporting that FARC dissidents who abandoned the peace process in Colombia traveled to Havana to seek the regime's support.

Cuba also harbors several U.S. fugitives from justice wanted on charges of political violence, many of whom have resided in Cuba for decades. For example, the Cuban regime has refused to return Joanne Chesimard, aka Assata Shakur, a fugitive on the FBI's Most Wanted Terrorists List, who was convicted of executing New Jersey State Trooper Werner Foerster. Cuba also has refused to return William "Guillermo" Morales, a fugitive bomb maker for the Armed Forces for National Liberation (FALN), who is wanted by the FBI and escaped detention after being convicted of charges related to domestic terrorism; Ishmael LaBeet, aka Ishmael Muslim Ali, who received eight life sentences after being convicted of killing eight people in the U.S. Virgin Islands in 1972 and hijacking a plane to flee to Cuba in 1984; Charles Lee Hill, who has been charged with killing New Mexico State Policeman Robert Rosenbloom in 1971; and Ambrose Henry Montfort, who used a bomb threat to hijack a passenger aircraft and fly to Cuba in 1983. Cuba is also believed to host or have hosted U.S. fugitive terrorists Catherine Marie Kerkow and Elizabeth Anna Duke. The Cuban government provides housing, food ration books, and medical care for all of the fugitives residing there.

Venezuela. The regime allows and tolerates the use of its territory by terrorist organizations. Much of Venezuela is ungoverned, under-governed, or ill-governed. At times, the regime has openly welcomed terrorist activities in its territory. On July 28, during the closing remarks of the Sao Paolo Forum in Caracas, Maduro stated that Iván Márquez and Jesús Santrich (former FARC leaders who were at that time missing and widely presumed to have left the peace process and returned to terrorist activities) were both welcome in Venezuela. On August 29, both Márquez and Santrich appeared in a video in which they were wearing uniforms, carrying weapons, and calling for the FARC to return to arms against the Colombian government. The democratically elected National Assembly criticized the regime's provision of territory, Venezuelan national identification, and passports for members of the terrorist organization. Venezuela is also a permissive environment for the ELN and Hizballah sympathizers.

\section{COUNTERING TERRORISM ON THE ECONOMIC FRONT}

In 2019, the Department of State designated one new FTO and amended two existing FTO designations by adding aliases (changing the primary name of one of the groups in the process). In addition, the Department designated 19 organizations and individuals as Specially Designated Global Terrorists (SDGTs) under Executive Order (E.O.) 13224, as amended. The Department also reviewed and maintained the FTO designation of nine entities (treating a pre-existing alias of one of the groups as that group's primary name going forward). 
The Department of the Treasury also designated entities and individuals under E.O. 13224, as amended. For a list of all U.S. designations, see the Department of the Treasury's Office of Foreign Assets Control.

On September 9, the President amended Executive Order 13224 to enable the Departments of State and the Treasury to more effectively sanction the leaders of terrorist organizations and those who train to commit acts of terrorism. This amendment is the most significant update of terrorist designation authorities since the aftermath of the 9/11 attacks. With this amendment, designations under Executive Order 13224 now also carry secondary sanctions implications. The Department of the Treasury can prohibit or impose strict conditions on the opening or maintaining in the United States of a correspondent account or payable-through account of any foreign financial institution that knowingly conducts or facilitates a significant transaction on behalf of any person designated pursuant to Executive Order 13224.

\section{Foreign Terrorist Organization/Executive Order 13224 Group Designations}

- On March 22, the Department of State amended the E.O. 13224 and FTO designations of the Islamic State of Iraq and Syria (ISIS) to include the aliases Amaq News Agency and Al Hayat Media Center. (See Chapter 5, Foreign Terrorist Organizations, for further information on ISIS.)

- On April 15, the Department of State designated the Islamic Revolutionary Guard Corps (IRGC) as an FTO. See Chapter 5, Foreign Terrorist Organizations, for further information on the IRGC.) The Department of the Treasury designated the IRGC as a Specially Designated Global Terrorist (SDGT) on October 13, 2017, based on activities it undertakes to assist in, sponsor, or provide financial, material, or technological support for, or financial or other services to or in support of, the IRGC-Qods Force (IRGC-QF), which had previously been designated as an SDGT.

- On July 2, the Department of State amended the E.O. 13224 and FTO designations of Jundallah to include the aliases Jaysh al-Adl, Jeysh al-adl, Army of Justice, Jaish ul-Adl, Jaish al-Adl, Jaish Aladl, and Jeish al-Adl, and concluded that Jaysh al-Adl should be used as the group's primary name. (See Chapter 5, Foreign Terrorist Organizations, for further information on Jaysh al-Adl.)

- On December 20, in the course of reviewing and maintaining the designation of the al-Mulathamun Battalion, the Department of State concluded that the pre-existing alias al-Murabitoun should be used as the group's primary name.

\section{Executive Order (E.O.) 13224 Designations}

- On March 5, the Department of State designated Harakat al-Nujaba (HAN), an Iranian proxy group established in 2013. HAN is an Iran-backed Iraqi militia funded by but not under the control of the Iraqi government. HAN has openly pledged its loyalties to Iran and Iranian Supreme Leader Ayatollah Khamenei.

- On March 5, the Department of State designated Akram 'Abbas al-Kabi. Al-Kabi established Harakat al-Nujaba (HAN) in 2013.

- On July 2, the Department of State designated Husain Ali Hazzima, the Chief of Hizballah Unit 200. Unit 200 is the Intelligence Unit of Hizballah, and it analyzes and assesses information collected by Hizballah military units. 
- On July 2, the Department of State designated the Balochistan Liberation Army (BLA), an armed separatist group that targets security forces and civilians, mainly in ethnic Baloch areas of Pakistan. BLA has carried out several terrorist attacks, including a suicide attack in August 2018 that targeted Chinese engineers in Balochistan, a November 2018 attack on the Chinese consulate in Karachi, and a May 2019 attack against a luxury hotel in Gwadar, Balochistan.

- On July 16, the Department of State designated Ali Maychou. Maychou has served in a leadership role in Jama' at Nusrat al-Islam wal-Muslimin (JNIM) since its inception in 2017; has previously claimed responsibility for an attack on a military camp that housed Malian Armed Forces in Gao, Mali, that killed dozens; and has had a role in operational activities of JNIM.

- On September 10, the Department of State designated Hajji Taysir, a senior leader in ISIS who reported to Abu Bakr al-Baghdadi. As the ISIS Wali of Iraq and former amir of IEDs, Taysir likely ordered IED attacks in the region. He was considered a booby-trap expert while working in ISIS's booby-trap headquarters in 2016.

- On September 10, the Department of State designated Abu Abdullah ibn Umar al-Barnawi, the amir of ISIS-West Africa. Al-Barnawi was previously active in Boko Haram.

- On September 10, the Department of State designated Hatib Hajan Sawadjaan. Sawadjaan is the amir of ISIS-Philippines and is the mastermind behind the January 27, 2019, Jolo City cathedral bombing that killed 23 and wounded 109.

- On September 10, the Department of State designated Hurras al-Din, an al-Qa'ida-affiliated jihadist group that emerged in Syria in early 2018 after several factions broke away from Hayat Tahrir al-Sham.

- On September 10, the Department of State designated Faruq al-Suri, also known as Abu Humam al-Shami. Al-Suri is a Syrian national, a former al-Nusra Front military commander in Syria, and the current leader of Hurras al-Din.

- On September 10, the Department of State designated Ibrahim 'Aqil. Aqil is a senior Hizballah Jihad Council member and Hizballah's military operations commander.

- On September 10, the Department of State designated Fu'ad Shukr. Shukr is a senior Hizballah Jihad Council member who oversees Hizballah's specialized weapons units in Syria, including its missile and rocket unit. He is a senior military advisor to Hizballah Secretary General Hasan Nasrallah and played a central role in the planning and execution of the October 23, 1983, U.S. Marine Corps barracks bombing in Beirut, Lebanon, which killed 220 U.S. Marines, 18 U.S. Navy sailors, and 3 U.S. Army soldiers.

- On September 10, the Department of State designated Muhammad Haydar. Haydar is a senior leader within Hizballah's Jihad Council. Haydar was the Chief of Bureau 113, and ran Hizballah networks operating outside of Lebanon and appointed leaders of various units.

- On September 10, the Department of State designated Ali Karaki. Karaki is a senior leader within Hizballah's Jihad Council. He led Mu'awaniyeh 105 (Southern Command) and was responsible for military operations in southern Lebanon. Southern Command was divided into five geographic fronts (Mihwar), each consisting of a group of villages in a geographically contiguous strip. 
- On September 10, the Department of State designated Baha' Abu al-'Ata. Al-'Ata was a member of the Palestinian Islamic Jihad's Higher Military Council and a commander of the Gaza and North Battalion in the Al-Quds Brigade.

- On September 10, the Department of State designated Muhammad al-Hindi. Al-Hindi is the Deputy Secretary General of the Palestinian Islamic Jihad.

- On September 10, the Department of State designated Marwan Issa. Issa is the deputy commander of the Izz Al-Din Al-Qassam Brigades, the operational arm of Hamas.

- On September 10, the Department of State designated Noor Wali. Wali is the leader of Tehrik-e Taliban Pakistan (TTP) in June 2018 following the death of former TTP leader Mullah Fazlullah. Under Noor Wali's leadership, TTP has claimed responsibility for numerous deadly terrorist attacks across Pakistan.

- On November 7, the Department of State designated Amadou Kouffa. Kouffa is a senior member in JNIM, an al-Qa'ida affiliate active in the Sahel region of Africa.

\section{MULTILATERAL EFFORTS TO COUNTER TERRORISM}

In 2019, the United States continued to work through multilateral organizations to promote U.S. approaches to countering terrorism, and to strengthen regional and international counterterrorism efforts, including by developing and promoting global norms and building the capacities of states to implement them. Examples of U.S. multilateral engagement are described below.

The Global Counterterrorism Forum (GCTF). Founded in 2011 by the United States and Turkey, the GCTF aims to diminish terrorist recruitment and increase countries' capacity to deal with terrorist threats within their borders and regions by strengthening civilian institutions to counter terrorism. The GCTF comprises three thematic and two regional working groups: Countering Violent Extremism, Criminal Justice and the Rule of Law, Foreign Terrorist Fighters, Capacity Building in the East Africa Region, and Capacity Building in the West Africa Region. In September 2017, the United States and Jordan became co-chairs of the Foreign Terrorist Fighters Working Group for an initial two-year term. The United States and Jordan renewed their co-chairmanship of the FTF Working Group in 2019 for another two-year term, through September 2021. In September 2019, Canada succeeded the Netherlands as GCTF Co-Chair. Canada and Morocco will co-chair the GCTF through September 2021.

The UN is a close partner of, and participant in, the GCTF and its activities. The GCTF continued to increase cooperation and partnership as outlined in the September 2018 joint GCTF-UN statement marking enhanced cooperation between the two bodies. The GCTF serves as a mechanism to further the implementation of the universally agreed-upon UN Global Counter-Terrorism Strategy and, more broadly, to complement and reinforce existing multilateral counterterrorism efforts, starting with those of the UN. The GCTF also partners with a wide range of regional multilateral organizations, including the Council of Europe, the OSCE, the AU, the Intergovernmental Authority on Development, and ASEAN. 
In September 2019, GCTF ministers formally endorsed four new framework documents, including two co-led by the United States:

- "New York Memorandum on Good Practices for Interdicting Terrorist Travel." This initiative, co-led by Morocco and the United States, assists countries in implementing their obligations under UNSCR 2396 to prevent the travel of FTFs and other terrorists. The good practices contained in the New York Memorandum are intended to help countries and organizations build broader and more efficient watchlists and terrorist screening infrastructures. The New York Memorandum will serve as the basis of U.S.-led initiatives in 2019-2020.

- "Berlin Memorandum on Good Practices for Countering Terrorist Use of Unmanned Aerial Systems." Co-led by Germany and the United States, this initiative highlights the threat posed by terrorist use of unmanned aerial systems (UAS) against civilian targets. The document presents policy, legal, and technical tools to mitigate the threat.

- "Glion Recommendations on the Use of Rule of Law-Based Administrative Measures in a Counterterrorism Context." Nigeria and Switzerland, as co-chairs of the Criminal Justice and Rule of Law Working Group, co-led the development of this document that offers guidance to policy makers, law enforcement officials, and other relevant stakeholders for the design, implementation, and monitoring of administrative measures in a counterterrorism context.

- "Addendum to the GCTF Good Practices on Women and Countering Violent Extremism, with a Focus on Mainstreaming Gender." This addendum, co-led by Australia and Indonesia as co-chairs of the CVE Working Group, elaborates on existing GCTF good practices on women and CVE with new insights on gender-specific motivations and pathways of terrorist radicalization and CVE responses to counter women and girls' recruitment.

Also in September 2019, the GCTF launched three new initiatives, including two co-led by the United States:

- "The Watchlisting Guidance Manual." The United States and the UN are co-leading the development of a GCTF "toolkit" document that will elaborate on the non-binding good practices contained in the GCTF New York Memorandum. The resulting document will serve as a "toolkit" for nations to develop their own country specific watchlisting guidance and will pool collective knowledge of how to create and maintain effective watchlists of KSTs. This partnership with the UN is in support of the GCTF-UN commitment to strengthen cooperation.

- "The Initiative on Maritime Security and Terrorist Travel." The United States announced a two-year initiative to examine potential terrorist exploitation of the maritime sector for travel and how countries can take collective action to counter it. The initiative will produce a good practices document for endorsement in 2021 that will serve as an "addendum" to the GCTF New York Memorandum.

- "Initiative on Criminal Justice Responses to the Linkages between Terrorism, Transnational Organized Crimes, and International Crimes." Switzerland and 
Nigeria, as co-chairs of the Criminal Justice Rule of Law Working Group, announced a two-year project to examine criminal justice responses to the links between terrorism and crime. In 2019-2020, the Working Group will hold workshops to produce a good practices document on criminal justice responses to the links between terrorism and crimes including the financing of terrorism, corruption, trafficking in persons, illicit trafficking, and migrant smuggling.

- "Initiative on National-Local Cooperation in Preventing and Countering Violent Extremism." Australia and Indonesia, as co-chairs of the CVE Working Group, are co-leading the development of a good practices document to promote a whole-of-society approach as outlined in the UN Secretary-General's Plan of Action to Prevent Violent Extremism. The resulting document will strengthen "vertical cooperation" among governments and civil society groups

In 2019, the GCTF continued to work on several earlier initiatives, including promoting the non-binding good practices contained in the Zurich-London Recommendations on Preventing and Countering Violent Extremism and Terrorism Online. The United States also held a side event during the UN General Assembly High-Level Week in September 2019 on the threats, challenges, and resources related to FTF and family repatriation, and will continue to focus efforts on the challenge of returning families of FTFs.

GCTF-Inspired Institutions. The following three institutions were developed to operationalize GCTF good practices and to serve as mechanisms for strengthening civilian criminal justice responses to terrorism:

- The International Institute for Justice and the Rule of Law (IIJ). Since its establishment in June 2014, the IIJ has become a widely respected training institution for sustainable rule of law capacity building activities to criminal justice sector practitioners, including lawmakers, police, prosecutors, judges, corrections officials, and other justice sector stakeholders on how to address terrorism and related transnational criminal activities. In the last five years, the IIJ has trained over 4,500 criminal justice practitioners from 123 participating countries. While the United States has contributed the majority of funding in the establishment of the IIJ, investment from other donors has increased steadily, including from the EU, the United Kingdom, Switzerland, Germany, Canada, the Netherlands, and Spain. With U.S. funding, the IIJ in 2019 trained over 900 practitioners on issues such as battlefield evidence, addressing homegrown terrorism, combating prison radicalization, successful counterterrorism prosecution, increasing international cooperation in terrorism investigations and prosecutions, and juvenile justice. As an example of the IIJ's expanding role as a hub for rule-of-law based counterterrorism efforts, the IIJ hosted the first-ever International Senior Leaders Seminar on Battlefield Evidence in December 2019, convening senior counterterrorism officials from 36 countries and 18 multilateral organizations.

- Hedayah. On December 14, 2012, key GCTF member country senior officials inaugurated Hedayah, the first-ever international center of excellence for CVE, headquartered in Abu Dhabi, United Arab Emirates (UAE). Hedayah focuses on capacity building, dialogue and CVE communications, and research and analysis. Hedayah continued to organize capacity building workshops on CVE communications, 
education-based approaches to CVE, and CVE National Action Plans (NAPs). For example, Hedayah trained Western Balkans government officials on developing communication strategies to complement their CVE NAPs. Hedayah developed an East Africa "How-to Guide" for CVE communications and translated it into local languages. The organization held its fourth annual research conference in Australia. A 2019 evaluation of Hedayah's 2018 prevention through education program in one country yielded positive evidence of teachers adopting good practices after their training. The United States continued to fund an Abu Dhabi-based U.S. secondee as Hedayah's Director of Dialogue and CVE Communications.

- Global Community Engagement and Resilience Fund (GCERF). In September 2013, the GCTF called for the establishment of GCERF to serve as the first global fund to strengthen community resilience to terrorism. Based in Geneva, Switzerland, GCERF focuses on preventing and countering terrorism by building the capacity of small, local, community-based organizations. GCERF actively partners with seven beneficiary countries: Bangladesh, Kenya, Kosovo, Mali, Nigeria, the Philippines, and Tunisia. During 2019, GCERF grants directly empowered an estimated 1.2 million people at risk of terrorist recruitment and radicalization, and indirectly engaged a further estimated 6.2 million individuals. Since 2014, 14 countries, plus the EU, have contributed more than $\$ 85$ million to GCERF. In 2019, GCERF brought on two new donor countries.

The International Criminal Police Organization (INTERPOL). Through its I-24/7 secure global police communications system, INTERPOL connects member states' law enforcement officials to its investigative and analytical databases and to its system for sending messages and notices. The United States supports programs through INTERPOL's General Secretariat and the U.S. National Central Bureau (USNCB) to help countries affected by the FTF phenomenon extend I-24/7 connections from their national central bureaus to air, land, and sea ports of entry, thereby allowing them to screen against INTERPOL databases and interdict FTFs and other transnational criminals.

Acknowledging the value of this initiative and the importance of addressing the remaining connectivity gaps in countries at risk of FTF travel, in 2016 the G-7 committed to extending I-24/7 connectivity to 60 priority countries by 2021 . Since that time, the United States has engaged INTERPOL and USNCB to help fulfill the G-7 commitment by providing funding for projects aimed at extending connectivity in 12 countries. In the coming year, U.S. funds will enable further expansion of this program to additional priority countries.

The United States continued to support the INTERPOL Counter-Terrorism Fusion Centre's FTF project, which manages an analytical database containing identity profiles of FTFs compiled by connecting various types of available data (biometrics, travel documents, names, etc.). These profiles are effective in supporting law enforcement and border control authorities to identify and interdict suspected terrorists, ensuring that the right piece of data reaches the right officer on the frontlines. To support this initiative, the United States also has offered seed funding to support an INTERPOL project that will enhance the organization's analytical capability by allowing its databases to cross-reference data that link, for example, individual terrorist profiles with lost and stolen travel documents, or fingerprints found on IEDs. This capability will improve and speed up member states' investigative capacity. 
The United States also continued to support a range of counterterrorism capacity building activities through INTERPOL's Chemical, Biological, Radiological, Nuclear, and Explosive Materials sub-directorate.

European Union (EU). The 2010 U.S.-EU Agreement on the Terrorist Finance Tracking Program continued to enable the EU and the United States to share information related to financial messaging data for the purpose of identifying, tracking, and pursuing terrorists and their networks.

In 2019, the EU's strengthened external border checks continued to help prevent the travel of FTFs. In May, the European Border and Coast Guard Agency (Frontex) announced its first joint operation outside of the EU, deploying 50 officers to Albania in support of border security and managing migratory flows from Greece. The European Commission also signed two non-binding counterterrorism arrangements with Albania and North Macedonia in October. Europol has officers and personnel in Italy and Greece who work alongside border security and immigration officers to assist in screening incoming migrants against Europol databases. In cooperation with the FBI and EU member state law enforcement, Europol also established a task force in 2019 aimed at facilitating joint investigations and information sharing on FTF cases. In an effort to strengthen judicial cooperation and cross-border investigations targeting suspected terrorists among EU member state prosecutors, Eurojust established a European Judicial Counter Terrorism Register on September 1. The European Commission continued work on its Action Plan to Support the Protection of Public Spaces, which aims to enhance the capacity of member states to protect and reduce the vulnerability of soft targets, such as malls, restaurants, hotels, and other public spaces, against terrorist attacks. EU and United Kingdom officials discussed how the United Kingdom's exit from the EU would affect each organization's access to certain shared databases.

The EU also continued six military and law enforcement capacity building missions in the Horn of Africa and the Sahel, working closely with U.S. elements in counterterrorism, border security, and stabilization efforts. To date, the EU has pledged almost $\$ 270$ million for the G5 Sahel Joint Force, a coalition of five West African nations providing border security and counterterrorism operations in the Sahel. The EU has also initiated the Partnership for Stability and Security in the Sahel initiative to assess the security sector in West African countries and coordinate donor funding to fulfill their needs.

Organization for Security and Cooperation in Europe (OSCE). Under Slovakia as the 2019 Chair in Office, the OSCE approach to counterterrorism focused on security measures to prevent, interdict, and prosecute terrorists with respect for the rule of law; promoting a whole-of-society approach with close engagement with civil society and the private sector; using referral mechanisms and pre-criminal interventions to prevent terrorist radicalization and recruitment; emphasizing rehabilitation and reintegration of offenders; and ensuring the protection of human rights. Slovakia underscored this approach during the annual OSCE-wide 2019 Conference on Counterterrorism in Bratislava, March 25-26. At the conference, the United States sponsored a side event focused on Countering the Use of the Internet for Terrorist Purposes. This event opened with remarks on the U.S. approach of taking appropriate law enforcement action against criminal activities online and working through a "whole of government" approach to strengthen 
and expand ongoing voluntary collaboration with private sector technology companies to address online terrorist content. Panelists from the Swiss government, Facebook, Google, and UN-affiliated Tech against Terrorism discussed the need to counter the ability of terrorists to recruit and radicalize or inspire others online using a broad set of tools and for a comprehensive approach to counter the hateful terrorist narratives they continue to espouse and promote. On October 31 and November 1, the OSCE conducted a seminar on the role of passenger data exchange in counterterrorism and border security, with participation by U.S. CBP. In 2019, the United States continued to support the OSCE's Leaders against Intolerance and Violent Extremism program to empower local networks in Southeastern Europe and strengthen homegrown civil society CVE work. OSCE staff members actively participated in global and regional efforts supported by the United States through the IIJ and GCTF.

North Atlantic Treaty Organization (NATO). The NATO Leaders Meeting in December marked the Alliance's 70th anniversary and highlighted how NATO continues to enhance the Alliance's counterterrorism efforts. NATO is a member of the Defeat-ISIS Coalition and in 2019 continued its missions in Afghanistan and Iraq. In February, NATO defense ministers endorsed a framework to counter terrorist misuse of drones and support the development of Allied capabilities. Defense ministers also endorsed the "Non-binding Guidelines for Enhanced Civil-military Cooperation to Deal with the Consequences of Large-scale Chemical, Biological, Radiological or Nuclear Events Associated with Terrorist Attacks." These guidelines will help Allies and partners strengthen national resilience. In December, NATO leaders noted an updated Action Plan to enhance NATO's role in the international community's fight against terrorism, which supports the Alliance's efforts to address evolving terrorist threats.

Council of Europe (CoE). The CoE develops and reinforces legal standards to prevent and suppress acts of terrorism. It works to help member states fight terrorism more effectively by strengthening and improving their national legislation, as well as facilitating international cooperation while respecting human rights and in full respect of the rule of law.

The United States participates in the CoE as an observer. The CoE's counterterrorism priorities, as established in its current 2018-2022 Strategy, include preventing terrorism through criminal law and law enforcement measures, ensuring terrorist offences are investigated in the most efficient and quickest possible manner, and protecting persons against terrorism. The CoE continued to operate its 24/7 Network of Contact Points on Foreign Terrorist Fighters, a voluntary network that connects relevant authorities to counterparts for sharing threat information. The CoE also established in 2019 the Network of Contact Points for the Exchange of Information regarding the Legal Standing of Victims of Terrorism, which helps terrorism victims access other countries criminal justice systems. The United States joined both networks in 2019. The CoE Committee on Counter-Terrorism, the key coordinating body for the $\mathrm{CoE}$ activities to combat terrorism, held plenary meetings in May and November. The CoE coordinates with countries and other multilateral organizations and entities such as the UN, OSCE, Organization of American States (OAS), and the EU.

Group of Seven (G-7). France served as the 2019 G-7 President and focused its counterterrorism-related discussions on the G-7 Foreign and Security Ministerial commitments made in Spring 2019, which included: illicit trafficking in the Sahel region; FTFs; terrorist financing; terrorist radicalization; use of the Internet for terrorist purposes; aviation security; 
transnational organized crime; environmental crime; and trafficking in persons. A G-7 Charter on Digital Cooperation that included countering terrorism online was not passed by consensus support at the G-7 Summit. France issued the Charter as a non-affiliated document after the Summit. Within the G-7 Roma-Lyon Group meetings on counterterrorism and combating transnational organized crime, the United States worked with its counterparts to implement the G-7 Ise-Shima Action Plan on Countering Terrorism and Violent Extremism, including an initiative to generate greater G-7 political and financial support to connect priority countries to INTERPOL's I-24/7 secure global communications system. The G-7 Action Plan also promoted reforms of the UN's counterterrorism architecture and support for greater use of PNR systems, which were reflected in UNSCR 2396. The United States also sought to advance projects through the Roma-Lyon Group's expert groups on counterterrorism, transportation security, high-tech crime, migration, criminal legal affairs, and law enforcement.

Group of Twenty (G-20). Japan served as the 2019 G-20 Chair. Counterterrorism-related discussions were focused on terrorist use of the internet, culminating in the G-20 Osaka Leaders' Statement on Preventing Exploitation of the Internet for Terrorism and Violent Extremism Conducive to Terrorism, building upon the 2017 G -20 Hamburg Statement on this issue.

\section{Organization of American States' Inter-American Committee against Terrorism} (OAS/CICTE). OAS/CICTE, which has 34 member states and 70 observers, made strides in 2019 across its focus areas: cybersecurity, border management, preventing the financing of terrorism, preventing the proliferation of WMD, preventing violent extremism, and addressing the FTF phenomenon. On May 23-24, OAS/CICTE held its 19th Regular Session. In partnership with Canada as incoming chair, OAS/CICTE focused the meeting on critical infrastructure security and resilience, global and regional cooperation mechanisms, human resilience, countering terrorist narratives, and increasing information sharing. At the conclusion of the Session, member states committed to consider Chile's recommendation to create an informal information sharing network to facilitate timely exchange of counterterrorism information. In October, OAS/CICTE formally announced the launch of the Inter-American Network on Counterterrorism with funding support from Chile and the United States. The Network, the only one of its kind in the Americas, will operate on a 24/7 basis among OAS member states. By facilitating communication among points of contact designated by each member state, countries of the Western Hemisphere will be able to respond more effectively to terrorist threats.

Association of Southeast Asian Nations (ASEAN), the ASEAN Regional Forum (ARF), and the East Asia Summit (EAS). Counterterrorism activities with the 10-member ASEAN and 27-member ARF countries included annual meetings on counterterrorism and transnational crime and capacity building through ASEAN-related institutions in 2019. The United States is leading a three-part ARF workshop series on aviation security, designed to raise awareness of countries' obligations under UNSCR 2396 and explain helpful tools for implementation. The first workshop was held in Kuala Lumpur, Malaysia, in July, and participants discussed aviation security measures and capacity gaps in ARF countries to use and implement API/PNR data and systems. The ARF also endorsed the U.S.-proposed statement Aviation Partnership:

Soaring Ahead Together. The EAS, which includes the 10 ASEAN members plus Australia, China, India, Japan, New Zealand, Republic of Korea, Russia, and the United States, issued three 
statements in 2019, one of which had a counterterrorism nexus, the Australia-proposed statement on Countering Transnational Crime.

ASEAN adopted the Bali Work Plan to Prevent and Counter the Rise of Radicalisation and Violent Extremism 2019-2025 on November 29. The objective of this Work Plan is to provide an implementation framework to guide relevant ASEAN Sectoral Bodies/Organs/Entities in carrying out the necessary activities and monitor effectiveness in preventing and countering terrorist radicalization and recruitment. The United States supported the process of developing the Workplan through technical assistance and consulted with various stakeholders, such as ASEAN sectoral bodies and civil society organizations, to provide input on the Work Plan.

Asia-Pacific Economic Cooperation (APEC). APEC updated its comprehensive Consolidated Counter-Terrorism and Secure Trade Strategy in 2019. The Strategy, adopted in 2011, endorses the principles of security, efficiency, and resilience, and it advocates for risk-based approaches to security challenges across supply chains, travel, finance, and infrastructure. Members also focused on furthering the APEC Counter-Terrorism Working Group Strategic Plan 2018-2022, which set priorities in areas such as the evolving threat of FTFs, terrorist financing, border and critical infrastructure security, and information sharing.

The African Union (AU). There are two main bodies within the AU which lead its counterterrorism efforts: the Peace and Security Department's Defense and Security Division, located at the AU headquarters in Addis Ababa, and the African Center for the Study and Research of Terrorism (CAERT) in Algiers. In 2019, the AU made CAERT the lead for all the AU's CVE activity. CAERT priorities include: 1) building capacity of member states on $\mathrm{CT} / \mathrm{CVE}$; 2) developing and/or implementing member state CVE action plans; and 3) enhancing international cooperation to ensure relevant regional approaches are taken fully into account. In 2019, the United States continued its engagement on shared counterterrorism priorities as part of the United States-African Union Peace and Security Technical Working Group.

Other U.S. engagements with the AU's Peace Support Operations include:

G-5 Sahel. Burkina Faso, Chad, Mali, Mauritania, and Niger formed the G-5 Sahel in 2014 to focus on the four pillars of security, resilience, infrastructure, and governance. In 2019, the G-5 Sahel Joint Force conducted military operations to disrupt the activities of terrorist operations in trans-border regions of the five member states. Multiple countries, including the United States, France, and the EU have provided or pledged donor support to the G-5 Sahel Joint Force. 
The League of Arab States (LAS): LAS is a member of the Global Coalition to Defeat ISIS. Twice a year, LAS meets with member states' Ministries of Justice and Interior in Tunis, Tunisia. Counterterrorism efforts are also highlighted in the annual summit in March and in its annual ministerial in September. In 2019, the Arab League Council of Ministers passed a resolution on counterterrorism efforts, stressing the importance of member states' implementation of the UN Counterterrorism Strategy, as well as intensifying joint Arab action to address the phenomenon of terrorist fighters returning from areas of conflict and their families. The resolution also urged its member states to develop appropriate national legislations to prosecute and to punish for the use of forged identity and travel documents to move to conflict zones per national laws.

The United Nations (UN). Sustained and strategic engagement at the UN on counterterrorism issues is a priority for the United States. Throughout 2019, the UN remained actively engaged in addressing the evolving threat of terrorism to international peace and security, including through UNSCR 2462 on countering terrorist financing and UNSCR 2482 on addressing the terrorism and organized crime nexus.

Other U.S. engagement with UN actors on counterterrorism included the following:

- The UN Security Council's Counter-Terrorism Committee (CTC) and Counter-Terrorism Executive Directorate (CTED). The United States supported CTC and CTED efforts to analyze capacity gaps of member states to implement UNSCRs 1373, 1624, 2178, 2396, and other relevant counterterrorism resolutions, and to facilitate training and other technical assistance to UN member states. In 2019, CTED conducted its first assessment of the United States, which showcased U.S. leadership and good practices on counterterrorism. A particular focus of CTED's assessment was to highlight the collection, use, and analysis in the United States of API and PNR data. CTED's assessment of these important UNSCR 2396 obligations will help other states to better understand how to adopt and implement these crucial counterterrorism tools to defeat terrorist travel. CTED also conducted assessments of 16 other countries in 2019, including China in October, to assess their implementation of international counterterrorism obligations. In 2019, CTED engaged in a range of multilateral, regional, and bilateral activities including regional workshops on incorporating UNSCR 2341 on the protection of critical infrastructure (including commercial facilities and soft targets) from counterterrorism attacks into national counterterrorism strategies.

- The UN Office of Counter-Terrorism (UNOCT). The UNOCT continued to work closely with the $36 \mathrm{UN}$ entities plus INTERPOL and the World Customs Organization through the Global Counter-Terrorism Coordination Compact to ensure the balanced implementation of the four pillars of the UN Global Counter-Terrorism Strategy; strengthen the delivery of UN counterterrorism capacity building assistance to member states; and promote and improve visibility, advocacy, and resource mobilization for UN counterterrorism efforts. In 2019, UNOCT hosted a series of regional high-level conferences in Dushanbe, Ulaanbaatar, Nairobi, Minsk, Budapest and Abu Dhabi, to enable member states to exchange expertise and develop partnerships to collectively 
address a range of critical counterterrorism issues in preparation for the second UN Counterterrorism High Level Week that will be held in June 2020.

- During 2019, the Department of State's Bureau of Counterterrorism contributed more than \$31 million to fund a range of activities undertaken by the UNOCT, UN Office on Drugs and Crime (UNODC), UN Mine Action Service, UN Office for Project Services, INTERPOL, and the International Office for Migration, including:

- Supporting global implementation of the UN's Countering Terrorist Travel Program to help member states utilize API/PNR to defeat terrorist travel;

- Countering IEDs in Somalia;

- Building criminal justice sector capacity to prosecute terrorism crimes in Mali;

- Utilizing battlefield evidence in Niger for terrorism terrorist prosecutions and investigations;

- Building law enforcement capacity to prevent and respond to terrorist crimes in border communities in West Africa;

- Improving aviation security in Bangladesh;

- Building partner nations' capacity to manage terrorist inmates; and,

- Enhancing connectivity to INTERPOL's databases in priority countries.

- The UNSC 1267/1989/2253 ISIL (Da'esh) and al-Qa'ida Sanctions Committee. The United States worked closely with the UN Sanctions Committee and its monitoring team in 2019 by proposing listings, providing amendments, engaging the Committee's ombudsperson regarding petitions for de-listings, and providing input to the Committee to enhance its procedures and implementation of sanctions measures. The United States also assisted the monitoring team with information for its research and reports. In 2019, two groups and four individuals were added to the 1267 Sanctions List, including the designation of ISIS-Khorasan, the first ISIS affiliate ever listed at the UN. One group and eight individuals were de-listed; and one entity and 10 individuals had their existing entries amended during the year. The total figures on the list are 261 individuals and 84 entities as of December 31. The Committee also worked to ensure the integrity of the list by conducting regular reviews and by endeavoring to remove those individuals and entities that no longer meet the criteria for listing.

- The UN Office on Drugs and Crime (UNODC). The UNODC's Terrorism Prevention Branch (TPB) continued to assist countries seeking to ratify and implement the universal legal instruments against terrorism, and it provided assistance for countering the financing of terrorism in conjunction with the UNODC's Global Programme Against Money Laundering, Proceeds of Crime and the Financing of Terrorism.

The United States supported UNODC/TPB as a counterterrorism assistance implementer, particularly for programming focused on strengthening the criminal justice system's response to terrorism by member states. In 2019, the UN Commission on Crime Prevention and Criminal Justice adopted a biannual resolution on the UNODC's mandate to provide counterterrorism technical assistance, which preserved and expanded upon its efforts to prioritize and provide effect capacity building for member states. 
The United States continued to support UNODC/TPB programs designed to strengthen the legal regime against terrorism within a rule-of-law framework globally.

- The UN Development Programme (UNDP). The UNDP helps countries develop strategies to counter terrorism by deepening research on preventing violent extremism (PVE) in many parts of the world, including Africa and the Middle East. In 2019, UNDP collaborated with UNOCT in information sharing, outreach, and support to the development and implementation of national PVE action plans to member states that requested assistance. The United States continued to support UNDP's work and encouraged other like-minded countries to provide voluntary funding to strengthen community-police partnerships in high-risk communities.

- The UN Security Council (UNSC) 1540 Committee. The 1540 Committee monitors and facilitates efforts to implement UNSCR 1540 (2004) requirements, which address the nexus of proliferation concerns surrounding chemical, biological, and nuclear weapons and their means of delivery on the one hand, and activities by nonstate actors, who wittingly or unwittingly provide WMD-related assistance to terrorist organizations on the other. The Committee's Group of Experts (GoE) participates in a wide range of multilateral and regional activities designed to facilitate technical assistance to member states when they request it. Using Office for Disarmament Affairs Trust Fund resources to cover travel expenses, the GoE has also interacted with the OPCW, the IAEA, the Biological and Toxin Weapons Convention, World Customs Organization, INTERPOL, UNODC, the FATF, and other multilateral counterterrorism bodies, as well with individual countries to this end. The United States is one of eight countries, plus the EU, that have contributed to the 1540 Trust Fund, which is used to support these activities as well as to financially support 1540 regional coordinator positions in the OAS and OSCE. The United States is working with the EU to co-fund AU 1540 Coordinators, and likewise is in discussions with Northeast Asian partners to support an ASEAN 1540 Coordinator position. U.S. funds also continued to be used to conduct projects that assist African, Middle Eastern, and Asian countries in strengthening national 1540 implementation by developing voluntary national implementation plans (NAPs). Given the key role played by current 1540 Coordinators in GoE-supported peer-to-peer reviews, the United States will continue to promote the idea of establishing additional 1540 Regional Coordinators so as to increase the number and quality of NAPs in the lead-up to an early 2021 UNSCR 1540 Comprehensive Review.

The International Civil Aviation Organization (ICAO). In May 2019, ICAO participated in the launch of the UN's Countering Terrorist Travel Programme at UN Headquarters in New York where Secretary General Dr. Fang Liu emphasized that aviation security and the facilitation of passenger movements are important and reciprocal priorities in air transport, and outlined the advancements that ICAO has made in support of the corresponding obligations and provisions defined in UNSCRs 2178, 2309, 2368, and 2396 in relation to halting the travel of FTFs. ICAO began drafting PNR Standards and Recommended Practices as called for in UNSCR 2396 (2017), which will assist UN member states to develop capabilities to collect, process and analyze PNR data, and share it with all of their competent national authorities. In September 2019, ICAO convened its third annual Global Aviation Security Symposium at 
ICAO Headquarters in Montréal, Canada, which brought together aviation security professionals from around the world to address the threat posed by terrorists targeting civil aviation, by reinforcing, strengthening, and promoting the international framework of aviation security standards.

The Global Initiative to Combat Nuclear Terrorism (GICNT). The United States serves as co-chair of GICNT, a voluntary partnership of 89 nations and six international observer organizations committed to strengthening national and global capacity to prevent, detect, and respond to the shared threat of nuclear terrorism. In 2019 the GICNT conducted eight multilateral activities that improved the plans, policies, procedures, and inter-operability of partner nations in technical areas such as nuclear detection, nuclear forensics, national emergency response frameworks, legal frameworks, and sustainability. At the 2019 GICNT Plenary meeting, the United States was endorsed as co-chair for an additional four-year term. In addition to serving as co-chair, the United States provides both financial and human resources to support the initiative's multilateral undertakings.

Financial Action Task Force (FATF). The FATF is an inter-governmental body that sets standards and promotes effective implementation of legal, regulatory, and operational measures to combat money laundering, terrorism financing, and proliferation financing. The FATF's efforts to improve understanding and compliance with global FATF standards are supported by FATF-style regional bodies around the world. The United States served as president of the FATF from July 2018 to June 2019. During its presidency, the United States prioritized the FATF's efforts to counter the financing of terrorism, culminating in the July 2019 publication of Terrorist Financing Risk Assessment Guidance, which aimed to assist countries in assessing terrorist financing risk by providing good practices and information resources based on country-specific experiences.

\section{LONG-TERM PROGRAMS AND INITIATIVES DESIGNED TO COUNTER TERRORIST SAFE HAVENS AND RECRUITMENT}

\section{COUNTERING VIOLENT EXTREMISM (CVE)}

Countering terrorist radicalization and recruitment is an essential counterterrorism tool. Our strategy to defeat terrorism includes efforts to build the capacity of local actors to defeat terrorism at its source. This is how we define our CVE efforts - protecting the United States, our interests, and our allies by reducing the ability of terrorists to radicalize, recruit, mobilize, and inspire acts of terrorism. In 2019, through bi-lateral and multilateral engagement, the Bureau of Counterterrorism (CT Bureau) emphasized four key areas in strategy formulation, diplomatic engagement, and foreign assistance programming. They include: countering all forms of terrorist ideologies, countering use of the internet for terrorist purposes, rehabilitation and reintegration, and counter-messaging. The CT Bureau partnered with government officials, community leaders, mental health professionals and social workers, religious figures, and others to build a prevention architecture to counter terrorist radicalization and recruitment. 


\section{Countering Terrorist Ideologies}

- The CT Bureau strengthened its efforts to refute the underlying terrorist ideologies of violence and intolerance, aiming to prevent the radicalization and recruitment of potential terrorists. The CT Bureau prioritized activities that counter terrorist ideology by building resilience to terrorist narratives, enhancing the capacity of youth to think critically, and challenging the influence of terrorist ideologues. These efforts included alternative pathways for those who may be susceptible to radicalization. The CT Bureau focused its efforts in both source countries, as well as recipient countries of terrorist ideology advocacy.

- The CT Bureau increased its efforts to combat racially or ethnically motivated terrorism (REMT). REMT, in particular white supremacist terrorism, continues to be a threat to the global community, with violence both on the rise and spreading geographically, as white supremacist and nativist movements and individuals increasingly target immigrants; Jewish, Muslim, and other religious minorities; lesbian, gay, bisexual, transgender and/or intersex (LGBTI) individuals; governments; and other perceived enemies. The CT Bureau is working with our law enforcement and foreign partners to take concrete actions to address this growing threat.

\section{Countering Use of the Internet for Terrorist Purposes}

- The CT Bureau continued promoting U.S. policy on this issue in bilateral and multilateral engagements. As global attention on how terrorists exploit internet-based platforms continues to grow, the CT Bureau worked to ensure the U.S. response was measured, and in-line with U.S. policy and legal frameworks for internet freedom and freedom of expression. The United States believes that protecting human rights and fundamental freedoms, including freedom of expression, is an important part of our counterterrorism strategy because increased censorship and other restrictions on human rights can lead to greater instances of terrorist radicalization. The CT Bureau played a leading role in coordinating and negotiating language that highlighted U.S. policy consistent with our long-standing ideals. While the United States was not in a position to endorse the Christchurch Call to Action for legal and policy reasons, the CT Bureau worked to ensure the U.S. position and general support on the issue was reflected in the G-20 Osaka Leaders' Statement on Preventing Exploitation of the Internet for Terrorism and Violent Extremism Conducive to Terrorism and in the G-7 Biarritz Strategy for an Open, Free, and Secure Digital Transformation. The CT Bureau engaged regularly with technology companies to improve voluntary information sharing, particularly on the presence of FTOs online. The CT Bureau also engaged regularly with the industry-led Global Internet Forum to Counter Terrorism (GIFCT) and UN-affiliated Tech Against Terrorism, highlighting the U.S. approach in working collaboratively with the private sector to counter the use of the internet for terrorist purposes. 


\section{Rehabilitation and Reintegration}

- Rehabilitation and reintegration of former terrorists as well as ISIS-associated family members has become a pressing concern for the global community. The CT Bureau coordinated global engagement on the rehabilitation and reintegration of FTFs and ISISassociated families repatriated from Syria and Iraq. The CT Bureau supported the travel of U.S. and international subject matter experts to Jordan, Kazakhstan, Kosovo, Kyrgyz Republic, the Maldives, North Macedonia, and Trinidad and Tobago to share best practices on rehabilitation and reintegration. These engagements, which emphasized the importance of providing returnees with psychosocial services and involving communitylevel stakeholders in the reintegration process, led multiple countries to update their approaches to rehabilitation and reintegration, which, in turn, could encourage other nations to agree to repatriate their citizens from Syria and Iraq.

\section{Counter-Messaging}

- The CT Bureau continues to work with the Global Engagement Center' Resiliency Campaign focused on Iraq, Syria, and Jordan as part of the Defeat-ISIS effort. This campaign focused on four areas: 1) create a local environment inhospitable to ISIS; 2) sustain global support to defeat ISIS; 3) portray ISIS as another failed movement; and 4) reduce ISIS's ability to disseminate propaganda used to recruit, radicalize, or mobilize supporters. This campaign brought together elements within the Department of Defense (DoD) to coordinate messaging efforts within specified countries.

- Through Hedayah, the Abu Dhabi-based CVE Center of Excellence, the CT Bureau staff trained high-level government officials from North Macedonia, Kosovo, Bosnia and Herzegovina, and Albania on developing communication strategies to complement their CVE National Action Plans. Hedayah and the CT Bureau also developed an East Africa "How-to Guide" for CVE communications that was translated into Somali and Swahili.

\section{International Platforms to Advance CVE}

- In 2019, the CT Bureau maintained robust support for key international platforms that serve to push global CVE initiatives, while sharing the burden of CVE programs with global partners. In the past year, the CT Bureau has helped multilateral institutions raise millions of dollars for local CVE programming in targeted localities.

- Strong Cities Network (SCN): In 2019, the SCN expanded engagement to Central Asia, with Kazakhstan hosting a regional workshop in Almaty in December. SCN now has more than 130 members across six continents, including new members such as Calgary, Edmonton, and Ottawa in Canada. This year the City Pair program linked German cities with San Diego, just weeks before the tragic attack on a synagogue in in San Diego County, which killed one and injured three. Officials from San Diego reported that the network they built with partners through the SCN helped them effectively respond to this act of domestic terrorism in the United States. SCN also 
partnered with the Department's International Visitor Leadership Program to bring SCN representatives from Kenya to Washington DC, Pittsburgh, and San Diego.

- Global Community Engagement Resilience Fund (GCERF): Since its inception in 2004 as the global CVE fund, GCERF has raised more than $\$ 85$ million from 14 governments. This year, GCERF was able to bring on two new donors - Denmark and Spain. GCERF operated in seven countries (Bangladesh, Mali, Nigeria, Kosovo, Kenya, Philippines, and Tunisia) with expansion approved for Somalia and Sri Lanka. There were no community-based programs approved for Somalia or Sri Lanka in 2019. During 2019, GCERF grants have empowered 1.2 million people at risk of recruitment or radicalization directly, and engaged a further 6.2 million people indirectly.

- Hedayah: Hedayah continued advising and assisting governments and training civil society in CVE strategies and approaches, and providing them new tools.

Hedayah completed and launched two CT Bureau-funded community-oriented policing CVE training guides: Community-Oriented Policing for CVE Capacity and Creating Positive Policing Narratives for CVE. The CT Bureau conducted an evaluation of its 2018 prevention through education program in Uganda, which yielded positive evidence regarding teacher's adoption of good practices in their local communities after their training there. More broadly, the CT Bureau leveraged other U.S. and donor government support for Hedayah programming - including USAID support for CVE communications work in Kenya.

\section{CIVILIAN COUNTERTERRORISM CAPACITY-BUILDING PROGRAMS}

As the terrorist threat has evolved and significantly expanded geographically in recent years, it has become clear that mitigating this threat depends on the political will and enhanced capabilities of our partners to counter terrorism. To succeed over the long term, the United States must have partners who not only prevent, disrupt, and degrade networks militarily or through law enforcement, while comporting with international laws and norms, but also leverage robust civilian capabilities. The United States needs partners in law enforcement, the justice sector, and corrections who can prevent and disrupt attacks and investigate, arrest, prosecute, and incarcerate terrorists and their facilitation networks.

The United States supports various programs to build the capacity of law enforcement to counter terrorism, including by strengthening the ability of justice and corrections officials to counter terrorism. The Department of State's Bureau of Counterterrorism funds and oversees the following capacity building programs: the Antiterrorism Assistance program, the Countering Terrorism Finance program, Counterterrorism Engagement with Allies, the Terrorist Interdiction Program, and the Counterterrorism Partnerships Fund (CTPF). 
In FY 2019, CTPF resources allowed the Department of State to significantly expand civilian law enforcement counterterrorism capacity building activities with key partner nations in the Middle East, North Africa and the Sahel, the Horn of Africa, South and Central Asia, Southeast Asia, and other regions to mitigate the threat posed by FTFs, prevent and counter terrorist safe havens and recruitment, and counter Iran-sponsored terrorism. For further information on these programs, we refer you to the Annual Report on Assistance Related to International Terrorism.

\section{REWARDS FOR JUSTICE}

The Department of State's counterterrorism rewards program, Rewards for Justice (RFJ), was established by the 1984 Act to Combat International Terrorism, Public Law 98-533 (codified at 22 U.S.C. § 2708). RFJ's goal is to bring international terrorists to justice and prevent acts of international terrorism against U.S. persons or property.

Under this program, the Secretary of State may authorize rewards for information that leads to the arrest or conviction of anyone who plans, commits, aids, or attempts international terrorist acts against U.S. persons or property; that prevents such acts from occurring in the first place, that leads to the identification or location of a key terrorist leader; or that disrupts terrorism financing. Pursuant to a 2017 amendment, RFJ also provides rewards for certain information that leads to the disruption of financial mechanisms of persons supporting the North Korean regime or for information that leads to the identification or location or any individual who, acting at the direction or under the control of a foreign government, aids or abets a violation of the Computer Fraud and Abuse Act.

Since RFJ's inception in 1984, the United States has paid more than $\$ 150$ million to more than 100 people who provided actionable information that put terrorists behind bars or prevented acts of international terrorism worldwide.

In 2019, the RFJ program announced the following reward offers for information:

- February 19. Reward of up to $\$ 5$ million for information leading to the disruption of financial mechanisms of any person or entity engaged in actions that support the illicit activities of the North Korean Government.

- February 19. Reward of up to $\$ 5$ million for information that leads to the identification or location of any person who aids or abets a violation of the Computer Fraud and Abuse Act while acting at the direction or control of the North Korean regime.

- February 28. Reward of up to $\$ 1$ million for information leading to the identification or location in any country of al-Qa'ida key leader Hamza bin Laden.

- April 22. Reward of up to $\$ 10$ million for information leading to the disruption of the financial mechanisms of the global terrorist organization Lebanese Hizballah.

- July 19. Reward of up to $\$ 7$ million for information leading to the identification or location of Hizballah key leader Salman Raouf Salman, also known as Samuel Salman El Reda. 
- July 30. Reward of up to $\$ 5$ million for information on ISIS kidnapping networks responsible for kidnapping five Christian clerics, Maher Mahfouz, Michael Kayyal, Gregorios Ibrahim, Bolous Yazigi, and Paolo Dall'Oglio, in 2013.

- August 21. Reward of up to $\$ 5$ million each for information leading to the identification or location of key ISIS leaders Amir Muhammad Sa'id Abdal-Rahman al-Mawla, Sami Jasim Muhammad al-Jaburi, and Mu'taz Numa 'Abd Nayif Najm al-Jaburi.

- September 4. Reward of up to $\$ 15$ million for information leading to the disruption of the financial mechanisms of Iran's Islamic Revolutionary Guard Corps (IRGC) and its branches, including the IRGC-Qods Force (IRGC-QF).

- September 12. Reward of up to $\$ 5$ million each for information leading to the identification or location of senior Hurras al-Din leaders Faruq al-Suri, Abu 'Abd al-Karim al-Masri, and Sami al-Uraydi.

- October 4. Reward of up to $\$ 5$ million for information leading to the identification or location of Adnan Abu Walid al-Sahrawi, leader of the Islamic State in the Greater Sahara (ISIS-GS). ISIS-GS claimed responsibility for the October 2017 "Tongo Tongo" ambush of a joint U.S.-Nigerien patrol in Niger that led to the deaths of four U.S. soldiers.

- October 4. Reward of up to $\$ 5$ million for information leading to the arrest or conviction in any country of any individual who committed, conspired to commit, or aided or abetted in the commission of the 2017 ambush in Niger.

- November 4. Reward of up to $\$ 20$ million for information leading to the safe location, recovery, and return of retired FBI Special Agent Robert Levinson, who was kidnapped by the Iranian regime.

- November 7. Reward of up to $\$ 6$ million for information on Sa'ad bin Atef al-Awlaki, a Yemeni national and emir of Shabwah in Yemen.

- November 7. Reward of up to $\$ 4$ million for information leading to the identification or location of Ibrahim Ahmed Mahmoud al-Qosi, a Sudanese national who for decades has supported al-Qa'ida and its factions.

- December 5. As part of its reward offer for information leading to the disruption of the financial mechanisms of Iran's Islamic Revolutionary Guard Corps (IRGC), the U.S. Department of State's Rewards for Justice program requested information on the activities, networks, and associates of Abdul Reza Shahla'i, a Sana'a, Yemen-based high ranking commander of the IRGC's Qods Force (IRGC-QF).

\section{SUPPORT FOR PAKISTAN}

The President announced a new South Asia strategy on August 21, 2017, emphasizing Pakistan's important role with respect to regional security and the need for Pakistan to address the threat posed by terrorist groups operating within its territory. Counterterrorism cooperation between the United States and Pakistan continued with the aim of defeating ISIS-K and TTP.

In January 2018, the U.S. government suspended most of its security assistance to Pakistan over the government's failure to adequately address the threat posed by militant and terrorist groups operating on Pakistani soil. That suspension remained in effect throughout 2019. 
A recalibration of our civilian assistance portfolio was implemented in 2019 to target a narrower set of priority areas: people-to-people exchanges, law enforcement and counterterrorism cooperation, stabilization for the Afghanistan-Pakistan border, fostering trade and economic growth, supporting civil society, and helping treat polio and other infectious diseases.

U.S. support for civilian law enforcement and rule of law helped Pakistan provide security and justice for Pakistani citizens, and disrupt transnational organized crime and terrorism networks that operated within Pakistan's borders.

\section{Account}

\section{Total Bilateral Foreign Assistance}

Economic Support Fund

Global Health Programs

Intl. Narcotics Control and Law Enforcement

Nonproliferation, Antiterrorism, Demining

Foreign Military Financing

International Military Education and Training

Food for Peace Title II

*Figures in millions, US \$

$\begin{array}{ccc}\text { FY 2017 } & \text { FY 2018 } & \text { FY 2019 } \\ \mathbf{2 6 6 . 3} & \mathbf{7 3 . 8} & \mathbf{1 0 9 . 4} \\ 200.0 & 48.0 & 62.0 \\ 22.5 & 0.0 & 0.0 \\ 38.0 & 21.0 & 40.0 \\ 1.0 & 1.8 & 1.8 \\ 0.0 & 0.0 & 0.0 \\ 4.8 & 0.5 & 3.5 \\ .04 & 2.5 & 2.5\end{array}$

\section{COUNTERTERRORISM COORDINATION WITH SAUDI ARABIA}

Countering Violent Extremism (CVE). In 2019, Saudi Arabia continued to identify counterterrorism as one of the nation's top security policy priorities. Saudi authorities worked closely with the United States to implement counterterrorism commitments and to develop new capabilities to "monitor and counter extremist messaging." Saudi officials remain eager to enhance defense and security cooperation and expand engagement with the United States, including on CVE issues. Regular high-level consultations and cooperation with the United States played a crucial role in the Saudi Arabian government's (SAG) ability to manage domestic and regional terrorism threats. Saudi Arabia maintained adequate legal frameworks, security forces, and institutional preparedness to combat "extremist threats." Attacks by Iran and groups it sponsors or supports on Saudi Arabia, including Iranian attacks on Aramco oil processing facilities at Abqaiq and Khurais on September 14, 2019, spurred Saudi efforts to defend its territory against Iranian-backed terrorism. Saudi Arabia remained a regional leader in countering terrorist financing, leading efforts within the Terrorist Financing Targeting Center on anti-money laundering and counterterrorist financing (AML-CFT) measures.

On the multilateral front, Saudi Arabia worked closely on capacity building efforts to increase regional cooperation, minimize duplication of efforts, enhance information sharing, and address border security gaps. SAG leadership worked to advance counterterrorism cooperation with Muslim-majority states, including through the Islamic Military Counter Terrorism Coalition. Saudi Arabia participated actively in the Global Coalition to Defeat ISIS and provided significant support in facilitating U.S. military operations in the region. 
To promote a more comprehensive, collaborative, and proactive approach to CVE, Saudi activities focused on identifying pathways to terrorist radicalization and recruitment; and countering these by government messaging that emphasized nationalism, rejected intolerant ideologies, including those based on religious interpretations, and cultivated appreciation for Saudi culture and heritage as the basis for national identity. Saudi Arabia's ideological approach to countering terrorist propaganda also included family outreach initiatives; integration of gender considerations in CVE work; and public messaging campaigns to amplify moderate voices in mainstream media, mosques, Islamic organizations, community centers, and prisons, to curb the appeal of "radical ideology" and to counter "extremist messages." Security authorities continued to employ the Mohammed bin Naif Center for Care and Rehabilitation (or "MbN Center") to deprogram, monitor, and rehabilitate former Saudi terrorists or foreign fighters.

The government also encouraged inter-religious and inter-ethnic dialogue through religious conferences and visits that brought Saudi religious scholars together with their counterparts from other faiths to promote dialogue and tolerance across world faiths. Saudi Arabia has continued to remove hateful or inflammatory content from public school textbooks, though this project remains incomplete, and is encouraging public school teachers to integrate CVE considerations in their instruction. The USG continues to work with Saudi authorities to eliminate language that promotes discrimination, intolerance, or violence from textbooks and other government publications.

\section{U.S. AGENCY FOR GLOBAL MEDIA INITIATIVES: OUTREACH TO FOREIGN MUSLIM AUDIENCES}

\section{This section is provided by the U.S. Agency for Global Media (USAGM).}

We refer you to https://www.usagm.gov/wp-content/uploads/2020/04/usagm-Outreach-forForeign-Muslin-Aud.pdf for information on USAGM's outreach to foreign Muslim audiences.

\section{VISAS FOR PARTICIPANTS IN UNITED STATES PROGRAMS}

The Department of State's Bureau of Consular Affairs' visa policies and procedures have two fundamental missions: protecting national security by helping secure U.S. borders against actual or potential threats, while facilitating legitimate travel and international exchange. Focusing on these two missions both safeguards our nation's borders and ensures timely adjudications of visa applications for individuals seeking to participate in visitor exchange programs.

Visa applicants are subject to a robust interagency screening process that draws on biographic and biometric data. Applications may be refused because they require further interagency screening and vetting after the interview. Because of this, program sponsors and applicants should coordinate to initiate visa applications well in advance of their planned travel. We advise applicants to obtain passports immediately and visit www.travel.state.gov for instructions on applying for U.S. visas. 


\section{BASIC EDUCATION IN MUSLIM-MAJORITY COUNTRIES}

USAID provided the following information about their basic education programs in Muslim-majority countries.

In fiscal year (FY) 2019, USAID allocated \$329.5 million for basic education in countries with large Muslim populations. Estimated amounts for each region were:

- Asia: \$50.8 million was allocated to Bangladesh, the Kyrgyz Republic, the Philippines (Mindanao), and Tajikistan. An additional \$31 million was allocated to Afghanistan and \$10 million was allocated to Pakistan.

- Middle East and North Africa: \$149.75 million was allocated to Egypt, Jordan, Lebanon, Morocco, Syria, and Yemen.

- Sub-Saharan Africa: $\$ 85.9$ million was allocated to Burkina Faso, Djibouti, Mali, Niger, Nigeria, Senegal, and Somalia.

\section{ASIA}

Afghanistan: In 2019, USAID's Increasing Access to Basic Education and Gender Equality activity increased learning opportunities by maintaining 4,789 classes and transitioning 57,260 students (49 percent girls) to government schools. USAID also promoted girls' education through a \$25 million pledge to the United Kingdom's Department for International Development Girls' Education Challenge.

USAID's \$69.5 million Afghan Children Read (ACR) activity built the capacity of the Ministry of Education (MoE) to provide evidence-based early grade reading programs in Dari and Pashto for Grades 1-3. ACR reached 151,615 students (72,320 female) and 2,218 teachers (1,236 female). ACR distributed 674,467 teaching and learning materials to students and 960,008 supplementary reading materials to schools. USAID's Strengthening Education in Afghanistan II activity developed institutional capacities, policies, and guidelines for the purpose of establishing a regulatory environment for private sector schools. Under the Capacity Building activity, USAID supported the MoE by building capacity to increase transparency and accountability of national and subnational systems, policies, and procedures. USAID contributed $\$ 100$ million to the Education Quality Reform Activity in Afghanistan pledge as part of the Afghanistan Reconstruction Trust Fund and built six new schools in 2019. 
Bangladesh: The USAID/Bangladesh basic education program aimed to increase access to education and improve reading skills for children in lower primary grades. In FY 2019, USAID's Innovation for Improving Early Grade Reading Activity supported 17 urban districts across the country. As a result, 66 percent of students who completed Grade 2 demonstrated the ability to read with full comprehension compared to 28 percent of students in non-intervention schools. USAID also partnered with the U.S. Department of Agriculture to provide teaching and learning materials to 146 schools in Cox's Bazar, enabling 30,070 pupils (15,350 girls and 14,720 boys) from pre-primary grades to Grade 3 to directly benefit from early grade reading programs.

Kazakhstan: Basic education is a top priority for the Government of Kazakhstan and USAID is working to support Kazakhstani schools and teachers as they look to increase English language programs as part of the new trilingual education system. USAID works with teachers and students from schools in Kazakhstan to provide students higher quality English language and science, technology, engineering, and mathematics (STEM) instruction based on Western best practices and innovation. By providing improved English language instruction, USAID is helping students achieve greater English language proficiency and other skills that will help them find more opportunities for higher education, find gainful employment, and contribute to society.

Kyrgyz Republic: The USAID/Kyrgyzstan basic education program, Time to Read (TTR), continued to focus on improving children's reading skills. Through the TTR, USAID employed an evidence-based approach grounded in establishing reading curriculum standards, strengthening teachers' instructional practices through in-service and pre-service training. In 2019 USAID distributed 9,095 copies of 10 training modules in Russian and Kyrgyz to teachers, Instructional Support Team members and master trainers. The distribution of 188,848 copies of flashcard sets equipped teachers in 900 schools with teaching aides. USAID also published and distributed 488,725 copies of leveled supplementary reading materials, and 910 copies of a manual on Professional Learning Circles. The publishers' capacity to write grade-appropriate, gender-appropriate, and context-sensitive books that meet leveling criteria has been strengthened through a series of workshops with local authors and the development of a children's book development manual.

USAID also launched a new inclusive education activity to improve education among children with disabilities and ethnic minorities who speak minority languages. Ten target schools with 4,222 primary grade students were selected to be a part of the effort to bring students with disabilities into public schools. For the multilingual education component, the project identified 38 schools with 15,342 primary grade students. Two packages of training materials for the pilot schools were developed by a group of experts and training of school teachers and administrators began.

Pakistan: In Pakistan, USAID activities expanded access to quality basic education for all. The Khyber Pakhtunkhwa Reconstruction Program completed construction and rehabilitation of 12 schools. The Pakistan Transition Initiative, a small grants program, rehabilitated 14 schools in Federally Administered Tribal Areas/Khyber Pakhtunkhwa in the aftermath of the 2016 earthquake. The Sindh Basic Education Program (SBEP) includes two major components: a school construction activity and the Sindh Community Mobilization Program. The SBEP school 
construction component, a government-to-government (G2G) school construction activity, achieved its target of constructing 28 schools in FY 2019, bringing the total number of newly constructed schools to 68 .

The Pakistan Reading Project (PRP) provided institutional support to over 27,900 classrooms for early grade reading instruction and 110 colleges and universities to deliver associate's and bachelor's degree programs in teaching, producing more than 1,000 graduates in 2019. PRP created and distributed over 1.5 million student learning materials and teacher instructional materials in local languages and trained more than 1,617 administrators and education officials and 2,600 new teachers in instructional techniques, effectively boosting the reading skills of over 177,107 children. Additionally, PRP supported 452 parent-teacher associations and other community-based school governance structures engaged in primary or secondary education.

Philippines: In 2019, USAID's Education Governance Effectiveness (EdGE) activity reached 92,068 primary-level learners, 42,548 of whom participated in EdGE reading programs. A total of 1,690 primary school educators completed professional development activities on executing evidence-based reading instruction. More than 1,832 school administrators completed professional development activities, and 593 Parent Teacher Associations or community-based school governance structures benefitted from the activity. EdGE also delivered 17,307 textbooks and other teaching and learning materials.

Tajikistan: USAID/Tajikistan continued to support education programs by supporting revisions of obsolete Soviet training practices. The five-year Read with Me project reached more than 265,312 students in 1,964 schools, representing about 40 percent of primary schools nationwide. Given that teachers are the single most influential force for increasing equity, access, and quality in education, USAID education programming in Tajikistan places a high priority on teachers' professional development. Read with Me provided 72 hours of training to 9,652 teachers, who then received a formal certification from the Republic Teacher Training Institute. In addition, the project provided 6,149 supplementary teaching materials for trained educators at the national, regional, and local levels for Tajik and Russian language schools.

A Multi-Input Area Development Financing Facility for Tajikistan partnership with the Aga Khan Foundation implemented an approach called Relevance Pedagogy in select schools. Education interventions in 96 schools provided mentoring for more than 1,000 teachers and 141 administrators, benefiting more than 12,000 learners.

Uzbekistan: The recently awarded Uzbekistan Education Activity will develop, test, implement, and evaluate effective and scalable education reforms that improve learning outcomes for Uzbek public school studs throughout the country. To achieve this, the activity will work in close coordination with the Ministry of Public Education to amplify its ability to transform the way schools are managed, teachers are trained, instruction is delivered, and learning materials (traditional and information and communication technology) are developed and used. The activity will also develop methods and strategies to increase transparency and accountability in schools and improve data collection and resource allocation as well as school management and service delivery. 


\section{MIDDLE EAST AND NORTH AFRICA}

Egypt: USAID has been an important partner in advancing the Government of Egypt's education reform efforts through the Early Grade Learning government-to-government activity that supports reading instruction in Grades 1-3 and remedial reading instruction in Grades 4-9 for students who are not reading at grade level. In FY 2019, USAID supported the Ministry of Education and Technical Education by training 114,999 Grade 1-3 teachers nationwide in reading instruction to build a solid foundation for lifelong learning for students across Egypt. USAID also provides critical support to basic education in community schools in the most marginalized rural communities in Egypt through the Literate Village activity. This activity uses an innovative intergenerational model to teach literacy to mothers and their primary school-aged children in community schools in three rural governorates in Egypt: Assiut, Beheira, and Sohag. In FY 2019, USAID's community school literacy activity provided reading instruction to 29,526 (10,593 boys and 18,933 girls) primary school learners and trained 1,597 (nine men and 1,588 women) primary school teachers on better methods of instruction in community schools. Literate Village also enrolled 18,309 women in literacy classes and established 269 Parent Teacher Associations to support community engagement in primary education.

Jordan: In FY 2019, USAID constructed and repaired 1,291 classrooms, benefiting 30,473 students nationwide, and engaged local communities, and strengthened the capacity of the central ministries, governorates, and field directorates to better plan, manage, and maintain their schools.

USAID continued to support the Jordan Compact Education Fund, a multi-donor funding mechanism that allowed 134,121 Syrian children to enroll in the formal education system and 2,969 previously out-of-school students to enroll in the Ministry of Education's (MoE) "catch-up" program, providing them the opportunity to gain the knowledge and accreditation needed to enroll in the public school system. The initial focus of the fund was to address an acute need; but in its final year, donors and the MoE have been working to ensure activities are included in the Ministry's ongoing strategy. In FY 2019, USAID's Non-Formal Education activity also provided a second chance to 447 students who had dropped out to re-enroll in school or attend vocational training. Additionally, USAID's Cultivating Inclusive and Supportive Learning Environments activity ensured that 1,250 MoE teachers gained professional development skills to address the psychosocial support needs of 38,021 students nationwide.

USAID's Early Grade Reading and Mathematics Initiative continued efforts to improve literacy and numeracy for kindergarten through Grade 3 students, reaching 387,977 learners reading at the primary level with U.S. government assistance.

Lebanon: In 2019 through the Quality Instruction Towards Access and Basic Education Improvement (QITABI) activity, USAID provided Arabic reading instruction training and technology skills training to over 900 teachers and coaches benefiting over 128,000 students. In May 2019, USAID conducted an assessment of 6,168 students that revealed 84.1 percent of them improved by at least one reading level. Activities under QITABI aim to reduce the barriers to schooling for vulnerable Lebanese and non-Lebanese children by providing transportation solutions to 100 schools nationwide. USAID procured 100 buses and started their delivery to 
100 public schools at the end of September 2018. In FY 2019, USAID completed the delivery of the buses and provided technical training to the assigned drivers and school principals on bus operations and child and road safety. The bus program has benefited 1,700 public school students, including refugees.

Morocco: In FY 2019, the Reading for Success (RFS) project continued enhancing educational attainment for Moroccan children at the primary level. The project supports the Ministry of National Education, Vocational Training, Higher Education and Scientific Research (MoE) in its reform initiative to improve access to quality education for all children. USAID's RFS project places a great focus on gender equity, inclusiveness, and capacity development throughout all its activities. To improve the learning attainment of children in primary schools, USAID continues to implement the National Program for Reading (NPR), which was launched in May 2017. NPR supports MoE efforts to enhance educational attainment for Moroccan children at the primary level by improving Arabic reading instruction. USAID develops the capacity of the MoE to design, implement, and assess evidence-based instruction approaches that respond to the needs of children in Morocco.

USAID also signed a Memorandum of Intent with the MoE, Lalla Asmaa Foundation, and University Mohamed V to develop and implement a teacher training program for deaf education. This activity's purpose is to establish a national deaf education teacher preparation and professional development program that is embedded in a Moroccan higher education institution and the teacher training institutes.

Syria: FY 2019 education funding, managed by the U.S. Department of State's Bureau for Near Eastern Affairs (NEA), provided remedial education and psychosocial support for school-aged children deprived of education under ISIS rule, trained teachers, and provided school books. NEA also supported school winterization and rehabilitation to improve the learning environment and increase student safety.

Yemen: In 2019, USAID's school feeding project, implemented by the World Food Program, reached 448,129 students across the country. With the provision of a daily nutritious snack, this activity helped bring children, who had previously stopped schooling, back to school. The activity also resulted in increased attendance rates. A by-product of the activity was its positive impact on the local economy: 60 percent of the commodities used for the school-feeding program were sourced locally.

USAID's education projects with International Rescue Committee and Save the Children provided access to safe and quality education to out of school children ages 6-14 in Aden, Lahj, Amran, Sana'a, Hodeidah, and Al Dhale'e governorates. In the first year of implementation, 2,234 learners were reached with alternative education methods. The projects also ensured family and community participation in the education of the learners, with 32 community governance structures reached in FY 2019. Engagement with parents and affected communities ensured local leadership and management of non-formal education centers, which is critical to increase enrollment and sustain access to safe learning spaces. 
During the reporting period, USAID supported UNICEF to provide equitable access to safe, inclusive and equipped learning spaces and child protection through schools. Since the start of the project, USAID met the educational needs of 1,203,381 conflict-affected children. This reporting period, a total of 133,879 children, (53 percent of whom are girls) were reached with Back to School campaigns, school bag kits, refurbished and safer schools, and psychosocial support.

\section{SUB-SAHARAN AFRICA}

Burkina Faso: FY 2019 funding is being used to support Education Cannot Wait (ECW) activities being implemented by UNICEF. ECW is focused on implementing multi-year resilience plans to address challenges to education as a result of conflict.

Djibouti: In 2019, the Djibouti Early Grade Reading Activity printed 17,000 copies of student textbooks and workbooks for the 2019-20 academic year. To support student instruction, the activity distributed 352 teacher guides, big books (pedagogical materials), and posters. In addition, 70 pedagogic advisors and inspectors and 214 teachers received training on the use of the new materials.

Mali: In 2019, USAID Mali, through the Selective Integrated Reading Activity (SIRA), implemented the bilingual balanced literacy approach to reading instruction in four regions (Bamako, Segou, Koulikoro and Sikasso), ensuring improved reading outcomes for 264,169 first and second grade learners. SIRA provided training and coaching to 325 pedagogical counselors, 7,239 first grade and second grade teachers and 3,986 school directors on the balanced literacy approach, gender equitable teaching practices, and classroom management. Support has been provided to School Management Committees, Parent-Teacher Associations, education commissions and Mothers' Associations. Monitoring student attendance and performance to increase reading outcomes was also a part of FY 2019 activities. SIRA trained 304 community development agents to mobilize communities and parents to encourage reading and distributed home reading kits to 264,169 parents. SIRA established 124 community libraries through private and public partnerships and supported a local radio campaign with messages on reading, mother tongue instruction, and girls' education.

The Education Recovery Support Activity (ERSA) supported 35 youth clubs in Gao and Menaka, which carried out community service projects. The process of designing and implementing community service projects offered youth clubs opportunities to learn about project design and management. The community service projects responded to the actual needs and concerns of their respective communities and the community development agent from the implementing partner facilitated a participatory process, including: 1) the assessment of community needs by the youth clubs; 2) the involvement of stakeholders including youth, community leaders, members of youth associations and other community members in the project's design; and 3) the monitoring of the community service projects. The financial contributions of ERSA to the community service projects (on average $\$ 700$ per village) were used to purchase materials and equipment not available in the community. The projects had to meet requirements for conflict-sensitivity, gender equity, and environmental protection. 
Through the Girls Leadership and Empowerment through Education (GLEE) activity, USAID Mali continued to support 60,000 adolescent girls (aged 10-18 years) in school by supporting their retention and the transition from primary to lower secondary school. Support included paying school fees, purchasing bicycles for very vulnerable lower secondary school girls, distributing uniforms, providing solar energy infrastructure for schools, building latrines for girls, etc. GLEE also supported 136 accelerated learning centers and implemented activities that target financial and socio-cultural barriers by improving safety in schools and communities. Eight hundred and sixteen school educators and 544 education administrators/officials were trained on gender equality.

The project also provided in-kind grants to the Comiteacute de Gestion Scolaire to reduce barriers to girls' access to school for 19,751 adolescent girls in primary and secondary school in the regions of Kayes and Mopti.

Niger: The USAID-funded Niger Education and Community Strengthening (NECS) activity was a nationwide pilot program that coupled targeted community mobilization with comprehensive early grade reading interventions for boys and girls in Grades 1-2. The seven-year activity operated in 183 primary schools in all of Niger's eight geographic regions. The activity ended on September 30, 2019. The NECS activity improved reading instruction and learning by developing Grade 1-2 curriculum materials, including student manuals and teacher guides, and conducting targeted training for teachers and school directors. Student performance was assessed through continuous and summative early grade reading assessments (EGRA). The most recent EGRA was conducted in May 2019, and at the Ministry's request, two types of schools were compared: the schools participating in the NECS activity, and the Ministry's "Reform Schools." The latter are schools that are piloting the Ministry's own reading curriculum, among other education reforms. Preliminary results indicate that the NECS activity schools outperformed the Ministry's pilot schools, both in Grade 1-2 reading.

Nigeria: During FY 2019, USAID launched multiple activities and also continued its support to state governments in northern Nigeria to increase access to quality learning and improve the reading skills of school-aged children. In Bauchi and Sokoto states, the Northern Education Initiative Plus activity produced and distributed three million textbooks and teachers' manuals to formal schools and National Foreign Language Centers (NFLC) in 10 local government areas of each state. USAID also helped 68,000 formerly out-of-school children qualify for mainstreaming into formal schools through a basic literacy program administered in 1,800 NFLCs. Additionally, more than 642,000 children in formal schools are currently learning to read, 20 percent more than anticipated for this period. This would be impossible without the 9,409 teachers and learning facilitators USAID trained on best practices for reading instruction, leading to significant drops in the number of children unable to read a single word.

In Borno and Yobe states, the new Addressing Education in North East Nigeria (AENN) activity seeks to respond to the immediate educational needs of 302,500 children affected by crisis and conflict through safe non-formal and formal education (over the life of the project), while laying a foundation for the sustainable improvement of education systems at the community and government levels. During FY 2019, the activity reached 50,201 male and 52,408 female students. AENN works to improve the capacity of education authorities to plan, manage, 
and oversee education services that are responsive to the evolving needs of the local context. This includes the collection and use of data for effective decision making and coordination among education partners in the harmonization of teaching and learning materials used in NFLCs. To address the post-conflict educational needs of internally displaced children in Borno State, USAID awarded the University of Maiduguri (UoM) a grant to design and implement activities to counter violent extremism in Borno State, including training in trauma management and psychosocial counseling for education stakeholders, curriculum development for a CVE diploma, and establishing a Learning Resources Development Group (LRDG). The LRDG will support the production and translation of teaching and learning materials for formal and non-formal schools that are culturally sensitive, inclusive, and responsive to the needs of children affected by insecurity and displacement. Materials will incorporate themes around conflict mitigation, diffusing tensions in the classroom, and supporting instruction for a multilingual environment. Borno state and UoM will work to increase resilience through the development of a conflict-sensitive program for basic and non-formal education.

Senegal: In close partnership with the Ministry of Education (MoE), USAID continued to roll out Lecture Pour Tous (LPT)/Reading for All, a five-year, \$71 million activity using local languages (Wolof, Pulaar, and Sereer) as the medium of reading instruction. LPT increases the availability and use of quality learning materials, improves teacher skills and behaviors, and enhances parental and community support in over 4,000 schools. In FY 2019, LPT covered every school in half the country's regions. Overall, LPT trained 4,916 teachers and 2,459 principals in new teaching and reading methods. In collaboration with the MoE, USAID adapted materials from the national curriculum, then printed and distributed 673,356 teaching and learning materials to teachers and principals officially endorsed by the MoE. At the 2019 midline, the Early Grade Reading Assessment (EGRA) demonstrated that students are now proficient in most basic early grade reading skills. Specifically, more than 70 percent of Grade 2 students meet expectations for listening comprehension, while 60 percent meet expectations for letter knowledge benchmarks compared with almost zero at the beginning of the activity. USAID's G2G reading activity mirrors the LPT approach in the northern Saint-Louis region. Working through MoE systems, it reached over 700 schools, 26 inspectors, 499 principals, 532 teachers, and 24,422 students. It helped the MoE to procure, print, and distribute 71,223 reading materials, provided teacher training and materials, conducted early grade reading assessments, and trained and supervised teachers in dynamic teaching methodologies and approaches.

As a result of the Passerelles activity, 1,675 children benefited from learning opportunities under the care of 27 volunteer educators, who were recruited and trained on the MoE-approved curriculum. For vocational training, Passerelles worked in collaboration with other USAID implementing partners to train 57 young people in gardening, poultry farming, and farm product processing. Additional activities focused on eight middle schools and 49 elementary schools. Over 600 teachers and principals were trained on safe learning environments, school gender-based violence prevention, and inclusive education. Finally, 15 facilitators were trained on remediation methodologies and are now mentoring 375 students to improve their performance in reading and mathematics. 
Somalia: In FY 2019, the Alternative Basic Education Activity (ABE), in its penultimate year of implementation, enrolled 623 boys, for a cumulative total of 20,107 (11,460 boys, 8,647 girls) students. The $96 \mathrm{ABE}$ schools are in agro-pastoralist and pastoralist communities in Jubaland and Southwest States, specifically, Gedo, Bakool, and Bay regions acutely affected by recent drought, and then floods, and where children are particularly vulnerable to al-Shabaab recruitment efforts. Other notable achievements include the distribution of 21,147, textbooks and teaching and learning materials, and the training of 447 community teachers.

ABE trained 672 community education committee (CEC) members (288 females) from all 96 schools in a six-day course on school management and resource mobilization.

Evidence suggests that supported CECs are having a positive influence on parents and other community members, who are now volunteering to bring water to school among other activities. $\mathrm{ABE}$ also supported a 10-day training in different locations for 3,072 $\mathrm{ABE}$ learners from all 96 Child-to-Child clubs (each club consists of 32 members) on life and soft skills. ABE's incorporation of Child-to-Child clubs has been effective in helping restore the emotional and psychosocial needs of affected children and their families, and empowering children to speak out for their rights.

USAID also provided direct support to the Ministry of Education, embedding a non-formal technical advisor in the Federal Ministry of Education, Culture and Higher Education.

This advisor helped the Ministry develop its Non-Formal Education policy framework via Federal member state consultations in Jubaland, South West, Galmudug, and Hirshabelle, plus Banadir Regional Authority. ABE partnered with Media INK to create a pilot radio program (12 weekly episodes of 20 minutes in duration) in order to reinforce classroom-based instruction. The episodes will air on select radio stations in 2020 including Radio Kismayo, Radio South West State, Radio Xudur, and Radio Gedo. After each radio show airs, audience feedback will be collected and shared. Radio programming has been shown by USAID's Office of Transition Initiatives stabilization program to be a promising medium to counter Al-Shabaab narratives where government reach is especially limited.

\section{ECONOMIC REFORM IN MUSLIM-MAJORITY COUNTRIES}

We refer you to https://www.usaid.gov/what-we-do/economic-growth-and-trade and https://www.usaid.gov/reports-and-data for information on USAID's economic reform programs. 


\section{Chapter 5: Foreign Terrorist Organizations}

Designations of Foreign Terrorist Organizations (FTOs) expose and isolate the designated terrorist organizations, deny them access to the U.S. financial system, and create significant criminal and immigration consequences for their members and supporters.

Moreover, designations can assist or complement the law enforcement actions of other U.S. agencies and governments.

In 2019, the Department of State designated Iran's Islamic Revolutionary Guard Corps (IRGC), including its Qods Force (IRGC-QF), as an FTO. The State Department also amended the designation of the Islamic State of Iraq and Syria (ISIS) to include the aliases Amaq News Agency and Al Hayat Media Center. The State Department amended the designation of Jundallah to add Jaysh al-Adl (and variants thereof) as the group's primary name. In the course of reviewing and maintaining the designation of the al-Mulathamun Battalion, the State Department concluded that the pre-existing alias al-Murabitoun should be used as the group's primary name.

\section{Legal Criteria for Designation under Section 219 of the Immigration and Nationality Act (INA) as Amended:}

1. It must be a foreign organization.

2. The organization must engage in terrorist activity, as defined in section 212 (a)(3)(B) of the INA (8 U.S.C. $\S 1182(a)(3)(B))$, or terrorism, as defined in section 140(d)(2) of the Foreign Relations Authorization Act, Fiscal Years 1988 and 1989 (22 U.S.C. $\$ 2656 \mathrm{f}(\mathrm{d})(2))$, or retain the capability and intent to engage in terrorist activity or terrorism.

3. The organization's terrorist activity or terrorism must threaten the security of U.S. nationals or the national security (national defense, foreign relations, or the economic interests) of the United States.

\section{U.S. Government Designated Foreign Terrorist Organizations}

Abdallah Azzam Brigades (AAB)

Abu Sayyaf Group (ASG)

Al-Aqsa Martyrs Brigade (AAMB)

Al-Ashtar Brigades (AAB)

Ansar al-Dine (AAD)

Ansar al-Islam (AAI)

Ansar al-Shari'a in Benghazi (AAS-B)

Ansar al-Shari'a in Darnah (AAS-D)

Ansar al-Shari'a in Tunisia (AAS-T)

Army of Islam (AOI)

Asbat al-Ansar (AAA)

Aum Shinrikyo (AUM) 
Basque Fatherland and Liberty (ETA)

Boko Haram (BH)

Communist Party of Philippines/New People's Army (CPP/NPA)

Continuity Irish Republican Army (CIRA)

Gama'a al-Islamiyya (IG)

Hamas

Haqqani Network (HQN)

Harakat ul-Jihad-i-Islami (HUJI)

Harakat ul-Jihad-i-Islami/Bangladesh (HUJI-B)

Harakat ul-Mujahideen (HUM)

Hizballah

Hizbul Mujahedeen (HM)

Indian Mujahedeen (IM)

Islamic Jihad Union (IJU)

Islamic Movement of Uzbekistan (IMU)

Islamic Revolutionary Guard Corps (IRGC)

Islamic State of Iraq and Syria (ISIS)

ISIS-Bangladesh

ISIS-Greater Sahara

Islamic State's Khorasan Province (ISIS-K)

ISIL-Libya

ISIS-Philippines

ISIS Sinai Province (ISIS-SP)

ISIS-West Africa

Jama'at Nusrat al-Islam wal-Muslimin (JNIM)

Jama'atu Ansarul Muslimina Fi Biladis-Sudan (Ansaru)

Jaish-e-Mohammed (JeM)

Jaysh Rijal Al-Tariq Al-Naqshabandi (JRTN)

Jemaah Ansharut Tauhid (JAT)

Jemaah Islamiya (JI)

Jaysh al-Adl

Kahane Chai

Kata'ib Hizballah (KH)

Kurdistan Workers' Party (PKK)

Lashkar e-Tayyiba (LeT)

Lashkar i Jhangvi (LJ)

Liberation Tigers of Tamil Eelam (LTTE)

Mujahidin Shura Council in the Environs of Jerusalem (MSC)

Al-MurabitounNational Liberation Army (ELN)

Al-Nusrah Front (ANF)

Palestine Islamic Jihad (PIJ)

Palestine Liberation Front-Abu Abbas Faction (PLF)

Popular Front for the Liberation of Palestine (PFLP)

Popular Front for the Liberation of Palestine-General Command (PFLP-GC)

Al-Qa'ida (AQ)

Al-Qa'ida in the Arabian Peninsula (AQAP) 
Al-Qa'ida in the Indian Subcontinent (AQIS)

Al-Qa'ida in the Islamic Maghreb (AQIM)

Real IRA (RIRA)

Revolutionary Armed Forces of Colombia (FARC)

Revolutionary People's Liberation Party/Front (DHKP/C)

Revolutionary Struggle (RS)

Al-Shabaab (AS)

Shining Path (SL)

Tehrik-e Taliban Pakistan (TTP)

ABDALLAH AZZAM BRIGADES

Also known as (aka) Abdullah Azzam Brigades; Ziyad al-Jarrah Battalions of the Abdallah Azzam Brigades; Yusuf al-'Uyayri Battalions of the Abdallah Azzam Brigades; Marwan Hadid Brigades; Marwan Hadid Brigade

Description: Designated as an FTO on May 30, 2012, the Abdallah Azzam Brigades (AAB) formally announced its establishment in a July 2009 video statement claiming responsibility for a February 2009 rocket attack against Israel. The Lebanon-based group's full name is Ziyad al-Jarrah Battalions of the Abdallah Azzam Brigades, named after Lebanese citizen Ziad al Jarrah, one of the planners of and participants in the September 11, 2001, attacks on the United States.

Activities: After its initial formation, $\mathrm{AAB}$ relied primarily on rocket attacks against Israeli civilians. It is responsible for numerous rockets fired into Israeli territory from Lebanon, often targeting population centers.

In 2013, AAB began targeting Hizballah for the organization's involvement in the Syrian conflict and support for Syrian regime forces. In November 2013, AAB claimed responsibility for a suicide bombing outside the Iranian Embassy in Beirut, Lebanon, which killed 23 people and wounded more than 140. In February 2014, AAB claimed twin suicide bomb attacks against the Iranian cultural center in Beirut that killed four people. In June 2014, AAB was blamed for a suicide bombing in the Beirut neighborhood of Tayyouneh, which killed a security officer and wounded 25 people.

In June 2015, the group released photos of a training camp for its "Marwan Hadid Brigade" camp in Syria, likely located in Homs province. From 2016 - 2018, AAB continued its involvement in the Syrian conflict and was active in Lebanon's Ain al-Hilwah refugee camp.

In December 2017, AAB called for violent jihad by Muslims against the United States and Israel after the U.S. announcement recognizing Jerusalem as Israel's capital. AAB did not claim responsibility for any attacks in 2018 or 2019, but announced its full dissolution in Syria in November 2019.

Strength: Precise numbers are unknown. 
Location/Area of Operation: Lebanon

Funding and External Aid: Sources of funding are unknown.

\section{ABU SAYYAF GROUP}

Aka al Harakat al Islamiyya (the Islamic Movement)

Description: The Abu Sayyaf Group (ASG) was designated as an FTO on October 8, 1997. ASG split from the Moro National Liberation Front in the early 1990s and is one of the most violent terrorist groups in the Philippines. The group claims to promote an independent Islamic state in western Mindanao and the Sulu Archipelago, and elements of the group have ties to ISIS's regional affiliate ISIS-Philippines.

Activities: ASG has committed kidnappings-for-ransom, bombings, ambushes of security personnel, public beheadings, assassinations, and extortion.

Throughout 2015, ASG was responsible for multiple attacks, kidnappings, and the killing of hostages. In 2016 and 2017, the group conducted kidnapping-for-ransom operations targeting Canadian, Norwegian, German, and Filipino citizens. In August 2017, ASG members killed nine people and injured others in an attack on Basilan Island. In July 2018, ASG detonated a car bomb at a military checkpoint on Basilan Island, killing 10 people, including a Philippine soldier and pro-government militiamen.

ASG continued conducting terrorist attacks and kidnappings in 2019. In May, ASG militants attacked Philippine soldiers on Jolo, resulting in the deaths of two children. In October, ASG kidnapped two British nationals from a beach resort in the Zamboanga region, but they were recovered on Jolo in November.

Strength: ASG is estimated to have hundreds of members.

Location/Area of Operation: Philippines and Malaysia

Funding and External Aid: ASG is primarily funded through its kidnapping-for-ransom operations and extortion. The group may also receive funding from external sources, including remittances from overseas Philippine workers and Middle East-based sympathizers. In the past, ASG has also received training and other assistance from regional terrorist groups such as Jemaah Islamiya.

\section{AL-AQSA MARTYRS BRIGADE}

Aka al-Aqsa Martyrs Battalion

Description: Designated as an FTO on March 27, 2002, the al-Aqsa Martyrs Brigade (AAMB) is composed of small cells of Fatah-affiliated activists that emerged at the outset of the al-Aqsa 
Intifada in September 2000. AAMB strives to expel the Israeli military and settlers from the West Bank in order to establish a Palestinian state loyal to Fatah.

Activities: During the 2000 Intifada, AAMB primarily carried out small-arms attacks against Israeli military personnel and settlers. By 2002, the group was striking at Israeli civilians inside Israel, and claimed responsibility for the first female suicide bombing in Israel. In 2010 and 2011, the group launched numerous rocket attacks on Israeli communities. In November 2012, AAMB claimed that it had fired more than 500 rockets and missiles into Israel during an Israel Defense Forces operation in Gaza.

In 2015, AAMB declared open war against Israel and asked Iran to help fund its efforts in a televised broadcast. Throughout 2015, AAMB continued attacking Israeli soldiers and civilians.

In March 2016, armed confrontation broke out in Nablus between Palestinian youths and Palestinian security officials following the arrest of an AAMB associate on murder charges; seven youths and six Palestinian security officials were injured in the unrest. AAMB claimed responsibility for two rockets fired at Israel from the Gaza Strip in March 2017 and six rockets in June 2018, although these did not cause any casualties. AAMB did not claim responsibility for any attacks in 2019.

Strength: AAMB is estimated to have a few hundred members.

Location/Area of Operation: Israel, Gaza, and the West Bank

Funding and External Aid: Iran has provided AAMB with funds and guidance, primarily through Hizballah facilitators.

\section{AL-ASHTAR BRIGADES}

\section{Aka Saraya al-Ashtar; AAB}

Description: Al-Ashtar Brigades (AAB) was designated as an FTO on July 11, 2018. AAB is an Iran-backed terrorist organization established in 2013 with the goal of violently overthrowing the ruling family in Bahrain. In January 2018, AAB formally adopted Iran's Islamic

Revolutionary Guard Corps branding and reaffirmed its loyalty to Tehran to reflect its role in an Iranian network of state and nonstate actors that operates against the United States and its allies in the region.

Activities: Since 2013, AAB has claimed responsibility for more than 20 terrorist attacks against police and security targets in Bahrain. In March 2014, AAB conducted a bomb attack that killed two police officers and an officer from the United Arab Emirates. In January 2017, AAB shot and killed another local Bahrain officer. AAB has also promoted violent activity against the British, Saudi Arabian, and U.S. governments over social media. In February 2019, $\mathrm{AAB}$ released a video statement promising more attacks in Bahrain to mark the anniversary of Bahrain's Arab Spring-inspired political uprising; however, the group did not claim responsibility for any terrorist attacks in 2019. 
Strength: Precise numbers are unknown.

Location/Area of Operation: Bahrain, Iran, and Iraq

Funding and External Aid: AAB receives funding and support from the Government of Iran.

\section{ANSAR AL-DINE}

Aka Ansar Dine; Ansar al-Din; Ancar Dine; Ansar ul-Din; Ansar Eddine; Defenders of the Faith

Description: The Mali-based group Ansar al-Dine (AAD) was designated as an FTO on March 22, 2013. AAD was created in late 2011 after its leader Iyad ag Ghali failed in his attempt to take over another secular Tuareg organization. Following the March 2012 coup that toppled the Malian government, AAD was among the organizations (which also included al-Qa'ida in the Islamic Maghreb [AQIM] and Movement for Unity and Jihad in West Africa) to take over northern Mali, destroy UNESCO World Heritage sites, and enforce a severe interpretation of Sharia law upon the civilian population living in the areas under its control.

Beginning in January 2013, French and allied African forces conducted operations in northern Mali to counter AAD and other terrorist groups, eventually forcing AAD and its allies out of the population centers they had seized. Ghali, however, remained free and appeared in AAD videos in 2015 and 2016 threatening France and the UN Multidimensional Integrated Stabilization Mission in Mali (MINUSMA).

In 2017, the Sahara Branch of AQIM, AAD, al-Murabitoun, and the Macina Liberation Front came together to form Jama'at Nusrat al-Islam wal-Muslimin (JNIM).

Activities: In early 2012, AAD received backing from AQIM in its fight against the Government of Mali, including for its capture of the Malian towns of Agulhok, Gao, Kidal, Tessalit, and Timbuktu. In March 2013, AAD members were reportedly among the Tuareg rebels responsible for killing 82 Malian soldiers and kidnapping 30 others in an attack against Agulhok. Before the French intervention in January 2013, Malian citizens in towns under AAD's control allegedly faced harassment, torture, and death if they refused to comply with the group's laws.

AAD was severely weakened by the 2013 French intervention, but increased its activities in 2015 and 2016. In 2016, AAD claimed responsibility for attacks targeting the Malian army and MINUSMA. In July 2016, AAD attacked an army base, leaving 17 soldiers dead and six missing. The following month, the group claimed three attacks: two IED attacks on French forces and a rocket or mortar attack on a joint UN-French base near Tessalit. In October and November 2016, AAD claimed responsibility for a series of attacks on UN and French forces. In February 2017, AAD claimed responsibility for an attack on the Malian Gendarmerie in Tenenkou, Mali. AAD did not claim responsibility for any attacks in 2018 and 2019.

Strength: Precise numbers are unknown. 
Location/Area of Operation: Mali

Funding and External Aid: AAD cooperates closely with and has received support from AQIM since its inception. AAD is also said to receive funds from foreign donors and through smuggling operations.

\section{ANSAR AL-ISLAM}

Aka Ansar al-Sunna; Ansar al-Sunna Army; Devotees of Islam; Followers of Islam in Kurdistan; Helpers of Islam; Jaish Ansar al-Sunna; Jund al-Islam; Kurdish Taliban; Kurdistan Supporters of Islam; Partisans of Islam; Soldiers of God; Soldiers of Islam; Supporters of Islam in Kurdistan

Description: Ansar al-Islam (AAI) was designated as an FTO on March 22, 2004. AAI was established in 2001 in the Iraqi Kurdistan region through the merger of two Kurdish terrorist factions that traced their roots to the Islamic Movement of Kurdistan. AAI seeks to expel western interests from Iraq and establish an independent Iraqi state based on its interpretation of Sharia law.

Activities: From 2003 to 2011, AAI conducted attacks against a wide range of targets including Iraqi government and security forces, and U.S. and Coalition forces. The group also carried out numerous kidnappings, murders, and assassinations of Iraqi citizens and politicians. In 2012, AAI claimed responsibility for the bombing of the Sons of Martyrs School in Damascus, which was occupied by Syrian security forces and progovernment militias; seven people were wounded in the attack.

During summer 2014, part of AAI issued a statement pledging allegiance to ISIS, although later reports suggest that a faction of AAI opposed joining ISIS. In October 2019, AAI claimed its first attack in Iraq in five years, placing two IEDs in Iraq's Diyala province.

Strength: Precise numbers are unknown.

Location/Area of Operation: Iraq and Syria

Funding and External Aid: AAI receives assistance from a loose network of associates in Europe and the Middle East.

\section{ANSAR AL-SHARI'A IN BENGHAZI}

Aka Ansar al-Sharia in Libya; Ansar al-Shariah Brigade; Ansar al-Shari'a Brigade; Katibat Ansar al-Sharia in Benghazi; Ansar al-Shariah-Benghazi; Al-Raya Establishment for Media Production; Ansar al-Sharia; Soldiers of the Sharia; Ansar al-Shariah; Supporters of Islamic Law

Description: Designated as an FTO on January 13, 2014, Ansar al-Shari'a in Benghazi (AAS-B) was created after the 2011 fall of the Qadhafi regime in Libya. The group has been 
involved in terrorist attacks against civilian targets as well as the assassination and attempted assassination of security officials and political actors in eastern Libya.

Activities: Members of AAS-B were involved in the September 11, 2012, attacks against the U.S. Special Mission and Annex in Benghazi, Libya. Four U.S. citizens were killed in the attack: Glen Doherty, Sean Smith, Tyrone Woods, and U.S. Ambassador to Libya

J. Christopher Stevens.

Throughout 2016, AAS-B continued its fight against the "Libyan National Army" in Benghazi, resulting in the deaths of numerous Libyan security personnel and civilians.

Additionally, AASB controlled several terrorist training camps in Libya and trained members of other terrorist organizations operating in Syria, Iraq, and Mali.

In May 2017, AAS-B announced its formal dissolution due to suffering heavy losses, including the group's senior leadership, as well as defections to ISIS in Libya. AAS-B has not claimed responsibility for any attacks since 2016.

Strength: Precise numbers are unknown.

Location/Area of Operation: Benghazi, Libya

Funding and External Aid: AAS-B obtained funds from al-Qa'ida in the Islamic Maghreb as well as through charities, donations, and criminal activities.

\section{ANSAR AL-SHARI'A IN DARNAH}

Aka Supporters of Islamic Law; Ansar al-Sharia in Derna; Ansar al-Sharia in Libya; Ansar alSharia; Ansar al-Sharia Brigade in Darnah

Description: Designated as an FTO on January 13, 2014, Ansar al-Shari'a in Darnah (AAS-D) was created after the 2011 fall of the Qadhafi regime in Libya. The group has been involved in terrorist attacks against civilian targets as well as the assassination and attempted assassination of security officials and political actors in eastern Libya.

Activities: Members of AAS-D were involved in the September 11, 2012, attacks against the U.S. Special Mission and Annex in Benghazi, Libya. Four U.S. citizens were killed in the attack: Glen Doherty, Sean Smith, Tyrone Woods, and U.S. Ambassador to Libya J. Christopher Stevens.

Throughout 2013 and 2014, AAS-D is believed to have cooperated with Ansar al-Shari'a in Benghazi in multiple attacks and suicide bombings targeting Libyan security forces in Benghazi. In 2016, AAS-D continued fighting in and around Darnah. Additionally, AAS-D maintained several terrorist training camps in Darnah and Jebel Akhdar, Libya, and trained members of other terrorist organizations operating in Syria and Iraq. 
In 2018, there were unconfirmed reports that AAS-D was involved in clashes with the "Libyan National Army." AAS-D did not claim any attacks in 2019.

Strength: Precise numbers are unknown.

Location/Area of Operation: Darnah, Libya

Funding and External Aid: Sources of funding are unknown.

\section{ANSAR AL-SHARI'A IN TUNISIA}

Aka Al-Qayrawan Media Foundation; Supporters of Islamic Law; Ansar al-Sharia in Tunisia; Ansar al-Shari'ah; Ansar al-Shari'ah in Tunisia; Ansar al-Sharia

Description: Designated as an FTO on January 13, 2014, Ansar al-Shari'a in Tunisia (AAS-T) was founded in 2011 by Seif Allah Ben Hassine. AAS-T has been implicated in attacks against Tunisian security forces, assassinations of Tunisian political figures, and attempted suicide bombings of popular tourist locations. AAS-T has also recruited Tunisians to fight in Syria.

Activities: AAS-T was involved in the September 14, 2012, attack against the U.S. embassy and American school in Tunis, which threatened the safety of more than 100 U.S. embassy employees. In February and July 2013, AAS-T members were implicated in the assassination of Tunisian politicians Chokri Belaid and Mohamed Brahmi.

Since 2016, Tunisian authorities have continued to confront and arrest AAS-T members. AAS-T did not claim responsibility for any attacks in 2019.

Strength: Precise numbers are unknown.

Location/Area of Operation: Tunisia and Libya

Funding and External Aid: Sources of funding are unknown.

\section{ARMY OF ISLAM}

Aka Jaysh al-Islam; Jaish al-Islam

Description: Designated as an FTO on May 19, 2011, the Army of Islam (AOI), founded in late 2005, is a Gaza-based terrorist organization responsible for numerous terrorist acts against the Israeli and Egyptian governments and British, New Zealand, and U.S. citizens. The group, led by Mumtaz Dughmush, subscribes to a violent Salafist ideology.

Note: AOI is a separate and distinct group from the Syria-based Jaysh al-Islam, which is not a designated FTO. 
Activities: AOI is responsible for the 2006 and 2007 kidnappings of civilians, including a U.S. journalist. AOI also carried out the early 2009 attacks on Egyptian civilians in Cairo and Heliopolis, Egypt, and planned the January 1, 2011, attack on a Coptic Christian church in Alexandria that killed 25 and wounded 100. In November 2012, AOI announced that it had launched rocket attacks on Israel in a joint operation with the Mujahidin Shura Council in the Environs of Jerusalem. In August 2013, an Israeli official reported that AOI leader Dughmush was running training camps in Gaza.

In September 2015, AOI reportedly released a statement pledging allegiance to ISIS. In a short post attributed to the group, AOI declared itself an inseparable part of ISIS-Sinai Province. Since then, AOI has continued to express support for ISIS. In October 2017, the group released a video in an effort to encourage ISIS fighters defending Mosul. In August 2019, AOI shared another video praising ISIS that included training information for individuals to conduct suicide attacks.

Strength: Precise numbers are unknown.

Location/Area of Operation: Egypt, Gaza, and Israel

Funding and External Aid: AOI receives much of its funding from a variety of criminal activities in Gaza.

\section{ASBAT AL-ANSAR}

Aka AAA; Band of Helpers; Band of Partisans; League of Partisans; League of the Followers; God's Partisans; Gathering of Supporters; Partisan's League; Esbat al-Ansar; Isbat al-Ansar; Osbat al-Ansar; Usbat al-Ansar; Usbat ul-Ansar

Description: Designated as an FTO on March 27, 2002, Asbat al-Ansar (AAA) is a Lebanon-based Sunni terrorist group composed primarily of Palestinians that first emerged in the early 1990s. Linked to al-Qa'ida and other Sunni terrorist groups, AAA aims to thwart perceived anti-Islamic and pro-Western influences in the country. AAA's base is largely confined to Lebanon's refugee camps.

Activities: Throughout the mid-1990s, AAA assassinated Lebanese religious leaders and bombed nightclubs, theaters, and liquor stores. The group also plotted against foreign diplomatic targets. Between 2005 and 2011, AAA members traveled to Iraq to fight Coalition Forces. AAA has been reluctant to involve itself in operations in Lebanon, in part because of concerns of losing its safe haven in the Ain al-Hilwah Palestinian refugee camp. AAA remained active in Lebanon but has not claimed responsibility for any attacks since 2018.

Strength: AAA membership is estimated in the low hundreds. 
Location/Area of Operation: AAA's primary base of operations is the Ain al-Hilwah Palestinian refugee camp in southern Lebanon.

Funding and External Aid: AAA likely receives money through international Sunni extremist networks.

\section{AUM SHINRIKYO}

Aka A.I.C. Comprehensive Research Institute; A.I.C. Sogo Kenkyusho; Aleph; Aum Supreme Truth

Description: Aum Shinrikyo (AUM) was designated as an FTO on October 8, 1997. It was established in 1987 by leader Shoko Asahara and gained legal status in Japan as a religious entity in 1989. The Japanese government revoked its recognition of AUM as a religious organization following the group's deadly 1995 sarin attack in Tokyo. Despite claims that the group has renounced violence and Asahara's teachings, members of AUM continue to adhere to the violent and apocalyptic teachings of its founder.

Activities: In March 1995, AUM members simultaneously released the chemical nerve agent sarin on several Tokyo subway trains, killing 13 and causing up to 6,000 people to seek medical treatment. Subsequent investigations by the Japanese government revealed that AUM was responsible for other chemical incidents in Japan in 1994, including a sarin attack on a residential neighborhood in Matsumoto that killed seven and injured approximately 500. Japanese police arrested Asahara in May 1995; in February 2004, authorities sentenced him to death for his role in the 1995 attacks.

Although AUM has not conducted a terrorist attack since 1995, concerns remain regarding its continued adherence to the violent teachings of Asahara. The group now consists of two factions, both of which have recruited new members, engaged in commercial enterprises, and acquired property. In July 2000, Russian authorities arrested a group of Russian AUM followers who planned to detonate bombs in Japan as part of an operation to free Asahara from prison. In August 2012, a Japan Airlines flight to the United States turned back after receiving a bomb threat demanding the release of Asahara.

In March 2016, Montenegro expelled 58 people associated with AUM found holding a conference at a hotel in Danilovgrad. One month later, Russian authorities carried out raids on 25 AUM properties and opened a criminal investigation into an AUM cell. In November 2017, Japanese police raided the offices of a "successor" group to AUM.

On July 6, 2018, AUM leader Shoko Asahara was executed. AUM did not claim any attacks in 2019.

Strength: AUM is estimated to have around 1,500 followers.

Location/Area of Operation: Japan and Russia 
Funding and External Aid: AUM's funding comes primarily from member contributions and group-run businesses.

\title{
BASQUE FATHERLAND AND LIBERTY
}

\begin{abstract}
Aka ETA; Askatasuna; Batasuna; Ekin; Euskal Herritarrok; Euzkadi Ta Askatasuna; Herri Batasuna; Jarrai-Haika-Segi; K.A.S.; XAKI; Epanastatiki Pirines; Popular Revolutionary Struggl

Description: Designated as an FTO on October 8, 1997, Basque Fatherland and Liberty (ETA) was founded in 1959 with the aim of establishing an independent homeland based on Marxist principles in the Spanish Basque provinces of Alava, Guipuzcoa, and Viscaya; the autonomous region of Navarre; and the southwestern French territories of Labourd, Lower-Navarre, and Soule.
\end{abstract}

Activities: ETA has primarily conducted bombings and assassinations against Spanish government officials, businessmen, politicians, judicial figures, and security and military forces; however, the group has also targeted journalists and major tourist areas. ETA is responsible for killing more than 800 civilians and members of the armed forces and police as well as injuring thousands since it formally began its campaign of violence in 1968 .

In December 2006, ETA exploded a massive car bomb, destroying much of the covered parking garage at Madrid's Barajas International Airport. ETA marked its fiftieth anniversary in 2009 with a series of high profile and deadly bombings, including the July 2009 attack on a Civil Guard barracks that injured more than 60 people, including children.

ETA has not conducted any attacks since it announced a "definitive cessation of armed activity" in October 2011.

In 2016, authorities seized ETA weapons, including a cache found in a forest north of Paris, and captured the top ETA leader. In April 2017, ETA reported that it had relinquished its last caches of weapons. In May 2018, ETA released a letter announcing the dissolution of its organizational structures. In a September 2019 mass trial, a Spanish court accepted a plea deal for 47 ETA members to avoid prison sentences for membership in the group.

Strength: Precise numbers are unknown.

Location/Area of Operation: Spain and France

Funding and External Aid: Sources of funding are unknown.

\section{BOKO HARAM}

aka Nigerian Taliban; Jama'atu Ahlus-Sunnah Lidda'Awati Wal Jihad; Jama'atu Ahlis Sunna Lidda'awati wal-Jihad; People Committed to the Prophet's Teachings for Propagation and Jihad; Sunni Group for Preaching and Jihad 
Description: Boko Haram (BH) was designated as an FTO on November 14, 2013. The Nigeria-based group is responsible for numerous attacks in northern and northeastern regions of the country as well as in the Lake Chad Basin in Cameroon, Chad, and Niger that have killed thousands of people since 2009.

In March 2015, BH pledged allegiance to ISIS in an audiotape message. ISIS accepted the pledge, and BH began calling itself ISIS-West Africa. In August 2016, ISIS announced that Abu Musab al-Barnawi was to replace Abubakar Shekau as the new leader of the group. Infighting then led BH to split. Shekau maintains a group of followers and affiliates concentrated primarily in the Sambisa Forest; this faction is known as Boko Haram, while al-Barnawi's group is now separated and designated as ISIS-West Africa.

Activities: $\mathrm{BH}$ crosses porous Lake Chad region borders to target civilians and military personnel in northeast Nigeria, the Far North Region of Cameroon, and parts of Chad and Niger. The group continued to evade pressure from Lake Chad country forces, including through the regional Multinational Joint Task Force.

Throughout 2014, BH killed about 5,000 Nigerian civilians in various attacks. In April 2014, the group kidnapped 276 female students from a secondary school in Chibok, Borno State. BH has continued to abduct women and girls in the northern region of Nigeria and the Lake Chad region, some of whom are subjected to domestic servitude, other forms of forced labor, and sexual servitude, including through forced marriages to its members. For further information, refer to the 2019 Trafficking in Persons Report.

In January 2015, BH carried out a massacre in Baga, Borno State; reported casualties ranged from 150 to more than 2,000 killed, injured, or disappeared. The January 2015 attacks and other BH operations in surrounding smaller villages in 2015 displaced an estimated 35,000 people and allowed BH to gain control of Borno State.

Between 2017 and 2018, BH increased its forced abduction of women and girls and ordered them to carry out suicide attacks on civilians, including the January 2017 attack against the University of Maiduguri in Borno State, and twin attacks against a mosque and market in Adamawa State, Nigeria, in May 2018, killing 86.

BH continued its terrorist attacks in 2018 and 2019. Between January and November 2019, BH reportedly killed at least 275 people, mostly civilians, and displaced thousands in the Far North Region of Cameroon. In February, the group killed at least 60 people in a renewed assault on the northeast Nigerian town of Rann. In July, at least 65 people were killed and 10 others injured in an attack by suspected BH fighters on a funeral in Borno State.

Strength: $\mathrm{BH}$ is estimated to have several thousand fighters.

Location/Area of Operation: Nigeria, Cameroon, Niger, and Chad

Funding and External Aid: BH largely self-finances through criminal activities such as looting, extortion, kidnapping-for-ransom, and bank robberies. 


\title{
COMMUNIST PARTY OF THE PHILIPPINES/NEW PEOPLE'S ARMY
}

\author{
Aka CPP/NPA; Communist Party of the Philippines; CPP; New People's Army; NPA; NPP/CPP
}

Description: The Communist Party of the Philippines/New People's Army (CPP/NPA) was designated as an FTO on August 9, 2002. The military wing of the Communist Party of the Philippines (CPP) - the New People's Army (NPA) - is a Maoist group formed in March 1969 with the aim of overthrowing the government through protracted guerrilla warfare. NPA's founder, Jose Maria Sison, reportedly directs CPP/NPA activity from the Netherlands, where he lives in self-imposed exile. Luis Jalandoni, a fellow Central Committee member and director of the CPP's overt political wing, the National Democratic Front, also lives in the Netherlands. Although primarily a rural-based guerrilla group, the CPP/NPA has an active urban infrastructure to support its terrorist activities and, at times, has used city-based assassination squads.

Activities: The CPP/NPA primarily targets Philippine security forces, government officials, local infrastructure, and businesses that refuse to pay extortion, or "revolutionary taxes." The CPP/NPA also has a history of attacking U.S. interests in the Philippines. In 1987, for example, the group killed three U.S. soldiers in four separate attacks in Angeles City. In 1989, the CPP/NPA issued a press statement claiming responsibility for the ambush and murder of Colonel James Nicholas Rowe, chief of the Ground Forces Division of the Joint U.S.-Military Advisory Group.

Over the past several years, the CPP/NPA has continued to carry out killings, raids, kidnappings, acts of extortion, and other forms of violence primarily directed against Philippine security forces.

Throughout 2016 and 2017, several attempts were made to establish a cease-fire and peace deal between the CPP/NPA and the Armed Forces of the Philippines. Reported violations from both sides, however - including reports of the CPP/NPA's continued recruitment in the Philippines and attacks against government forces and civilians - stalled peace efforts through 2019. In August 2018, seven suspected members of the CPP/NPA were killed in a shootout with Philippine police in the town of Antique; authorities found a cache of cellphones, laptops, firearms, and explosives at the site. In December 2018, CPP/NPA members attacked a military patrol in the city of Catarman using an anti-personnel mine. The attack killed four soldiers and two civilians.

In 2019, the CPP/NPA continued attacks on security forces and civilians. Their most deadly was in April, when they detonated bombs by an improvised land mine in a surprise early morning attack clash in Samar, killing six Philippine troops.

Strength: The Philippine government estimates that the CPP/NPA has about 4,000 members. The group also retains a significant amount of support from communities in rural areas of the Philippines. 
Location/Area of Operation: The Philippines

Funding and External Aid: The CPP/NPA raises funds through extortion and theft.

\title{
CONTINUITY IRISH REPUBLICAN ARMY
}

\begin{abstract}
Aka CIRA; Continuity Army Council; Continuity IRA; Republican Sinn Fein
Description: Designated as an FTO on July 13, 2004, the Continuity Irish Republican Army (CIRA) is a terrorist splinter group that became operational in 1986 as the clandestine armed wing of Republican Sinn Fein, following its split from Sinn Fein. "Continuity" refers to the group's belief that it is carrying on the original goal of the Irish Republican Army (IRA), to force the British out of Northern Ireland. CIRA cooperates with the larger Real IRA (RIRA).
\end{abstract}

Activities: CIRA has been active in Belfast and the border areas of Northern Ireland, where it has carried out bombings, assassinations, kidnappings, hijackings, extortion operations, and robberies. On occasion, it has provided advance warning to police of its attacks. Targets have included the British military, Northern Ireland security forces, and Loyalist paramilitary groups.

In February 2016, CIRA claimed responsibility for a shooting at a boxing event in Dublin that left one dead. In June 2017, CIRA released a statement claiming it would disband and decommission some of its arms over the following three months, describing the conflict as a "futile war."

In August 2019, CIRA members conducted an attack on the Police Service of Northern Ireland (PSNI), setting off a bomb near the border of North Ireland and the Republic of Ireland.

In December 2019, CIRA claimed responsibility for a grenade attack in west Belfast on a PSNI vehicle.

Strength: CIRA's membership is small, with possibly fewer than 50 members.

Location/Area of Operation: Northern Ireland and the Republic of Ireland

Funding and External Aid: CIRA supports its activities through criminal activities, including smuggling.

\section{GAMA'A AL-ISLAMIYYA}

Aka al-Gama'at; Egyptian al-Gama'at al-Islamiyya; GI; Islamic Gama'at; IG; Islamic Group

Description: Gama'a al-Islamiyya (IG) was designated as an FTO on October 8, 1997. Formed in the 1970s, IG was once Egypt's largest terrorist group. The group's external wing, composed mainly of exiled members residing in several countries, maintained that its primary goal was to replace the Egyptian government with an Islamist state. IG's "spiritual" leader Omar Abd al-Rahman, or the "blind Sheikh," served a life sentence in a U.S. prison for his involvement in the 1993 World Trade Center bombing and died in prison in February 2017.

Activities: During the 1990s, IG conducted armed attacks against Egyptian security, other government officials, and Coptic Christians. IG claimed responsibility for the June 1995 
attempted assassination of Egyptian President Hosni Mubarak in Addis Ababa, Ethiopia. The group also launched attacks on tourists in Egypt, most notably the 1997 Luxor attack. In 1999, part of the group publicly renounced violence. IG is not known to have committed a terrorist attack in recent years; the group remained dormant in 2019.

Strength: Precise numbers are unknown.

\section{Location/Area of Operation: Egypt}

Funding and External Aid: Sources of funding are unknown.

\section{HAMAS}

Aka the Islamic Resistance Movement; Harakat al-Muqawama al-Islamiya; Izz al-Din al Qassam Battalions; Izz al-Din al Qassam Brigades; Izz al-Din al Qassam Forces; Students of Ayyash; Student of the Engineer; Yahya Ayyash Units; Izz al-Din al-Qassim Brigades; Izz al-Din alQassim Forces; Izz al-Din al-Qassim Battalions; Izz al-Din al Qassam Battalions; Izz al-Din al Qassam Brigades; Izz al-Din al Qassam Forces

Description: Designated as an FTO on October 8, 1997, Hamas was established in 1987 at the onset of the first Palestinian uprising, or First Intifada, as an outgrowth of the Palestinian branch of the Muslim Brotherhood. The armed element, the Izz al-Din al-Qassam Brigades, has conducted anti-Israeli attacks, including suicide bombings against civilian targets inside Israel. Hamas also manages a broad, mostly Gaza-based, network of Dawa or ministry activities that include charities, schools, clinics, youth camps, fundraising, and political activities. After winning Palestinian Legislative Council elections in January 2006, Hamas gained control of significant Palestinian Authority (PA) ministries in Gaza, including the Ministry of Interior. In 2007, Hamas expelled the PA and Fatah from Gaza in a violent takeover. In 2017, the group selected a new leader, Ismail Haniyeh, who is based in Gaza. Hamas remained the de facto ruler in Gaza in 2019.

Activities: Before 2005, Hamas conducted numerous anti-Israeli attacks, including suicide bombings, rocket launches, IED attacks, and shootings. U.S. citizens have died and been injured in the group's attacks. In June 2007, after Hamas took control of Gaza from the PA and Fatah, the Gaza borders were closed, and Hamas increased its use of tunnels to smuggle weapons into Gaza through the Sinai and maritime routes.

Hamas fought a 23-day war with Israel from late December 2008 to January 2009. From November 14-21, 2012, Hamas fought another war with Israel during which it claims to have launched more than 1,400 rockets into Israel. Despite the Egypt-mediated cease-fire between Israel and Hamas in 2012, operatives from Hamas and Palestine Islamic Jihad (PIJ) coordinated and carried out a November bus bombing in Tel Aviv that wounded 29 people. On July 8, 2014, Israel launched Operation Protective Edge in Gaza with the intent of preventing rocket fire into Israel; the rocket fire from Gaza had increased following earlier Israeli military operations that targeted Hamas for the kidnapping and murder of three Israeli teenagers in June 2014, including 16-year-old U.S.-Israeli citizen Naftali Fraenkel.

In April 2016, a Hamas member carried out a suicide attack on a bus in Jerusalem, killing 20. The group was also held responsible for several Gaza-based rocket attacks, including a July strike in Sderot that hit a kindergarten and damaged several buildings. 
Hamas-organized protests at the border between Gaza and Israel continued throughout much of 2019, resulting in clashes that killed Hamas members, Palestinian protestors, and Israeli soldiers. Hamas claimed responsibility for numerous rocket attacks from Gaza into Israeli territory throughout 2018, and the Israeli military reported that some rocket attacks in 2019 came from Hamas launchers.

Strength: Hamas comprises several thousand Gaza-based operatives.

Location/Area of Operation: Gaza, the West Bank, and Lebanon

Funding and External Aid: Hamas has received funding, weapons, and training from Iran and raises funds in Gulf countries. The group receives donations from some Palestinian and other expatriates as well as from its own charity organizations.

\section{HAQQANI NETWORK}

\section{Aka HQN}

Description: Designated as an FTO on September 19, 2012, the Haqqani Network (HQN) was formed in the late 1980s, around the time of the then-Soviet Union's invasion of Afghanistan. HQN's founder Jalaluddin Haqqani established a relationship with Usama bin Laden in the mid-1980s, and joined the Taliban in 1995. After the fall of the Taliban in Afghanistan in 2001, Jalaluddin retreated to Pakistan where, under the leadership of his son Sirajuddin Haqqani, HQN continued to direct and conduct terrorist activity in Afghanistan. In July 2015, Sirajuddin Haqqani was appointed Deputy Leader of the Taliban.

Activities: HQN has planned and carried out numerous significant kidnappings and attacks against U.S. and Coalition Forces in Afghanistan, the Afghan government, and civilian targets. In September 2011, HQN wounded 77 U.S. soldiers in a truck bombing in Wardak province and conducted a 19-hour attack on the U.S. Embassy and International Security Assistance Force headquarters in Kabul, killing 16 Afghans. In June 2012, an HQN suicide bomb attack against Forward Operating Base Salerno killed two U.S. soldiers and wounded more than 100 others.

In April 2016, HQN was blamed for an attack in Kabul against a government security agency tasked with providing protection to senior government officials. This attack was the deadliest in Kabul in 15 years, killing 64 people and injuring more than 300. Afghan officials also blamed HQN for a June 2016 double suicide attack outside of Kabul against Afghan police cadets and first responders; 30 people were killed.

On May 31, 2017, a truck bomb exploded in Kabul, killing more than 150 people. Afghan officials blamed HQN for the attack. In October, an American woman and her family were recovered after five years of HQN captivity.

HQN was believed to be responsible for a January 2018 ambulance bombing in Kabul that killed more than 100 people. Afghan officials blamed HQN for a January 2018 attack on the Intercontinental Hotel in Kabul that killed 22 people, including Americans. HQN was also blamed for a May 2018 attack on the Afghan interior ministry that resulted in the death of a police officer. 
In November 2019, the HQN released two hostages, including a U.S. citizen, who were kidnapped at gunpoint in August 2016. Afghan authorities also released Anas Haqqani, a leading figure and fund-raiser for HQN.

Strength: HQN is estimated to have between 3,000 and 5,000 fighters.

Location/Area of Operation: Afghanistan and Pakistan

Funding and External Aid: HQN is primarily funded from taxing local commerce, extortion, smuggling, and other licit and illicit business ventures. In addition to the funding it receives as part of the broader Afghan Taliban, the group receives some funds from donors in Pakistan and the Gulf.

\section{HARAKAT-UL JIHAD ISLAMI}

Aka HUJI; Movement of Islamic Holy War; Harkat-ul-Jihad-al Islami; Harkat-al-Jihad-ul Islami; Harkat-ul-Jehad-al-Islami; Harakat ul Jihad-e-Islami

Description: Designated as an FTO on August 6, 2010, Harakat-ul Jihad Islami (HUJI) was formed in 1980 in Afghanistan to fight against the former Soviet Union. Following the Soviet withdrawal from Afghanistan in 1989, the group redirected its efforts towards India. HUJI seeks the annexation of the Indian state of Jammu and Kashmir into Pakistan and the expulsion of Coalition Forces from Afghanistan, and has supplied fighters to the Taliban in Afghanistan.

HUJI historically focused its activities on the Afghanistan-Pakistan front, and was composed of Pakistani terrorists and veterans of the Soviet-Afghan war. HUJI experienced internal splits, and a portion of the group has aligned with al-Qa'ida.

Activities: HUJI claimed responsibility for the September 7, 2011, bombing of the New Delhi High Court, which left at least 11 dead and an estimated 76 wounded. The group sent an email to the press stating that the bomb was intended to force India to repeal a death sentence of a HUJI member. HUJI did not claim responsibility for any attacks in 2019.

Strength: Precise numbers are unknown.

Location/Area of Operation: Afghanistan, India, and Pakistan

Funding and External Aid: Sources of funding are unknown.

\section{HARAKAT UL-JIHAD-I-ISLAMI/BANGLADESH}

Aka HUJI-B; Harakat ul Jihad e Islami Bangladesh; Harkatul Jihad al Islam; Harkatul Jihad; Harakat ul Jihad al Islami; Harkat ul Jihad al Islami; Harkat-ul-Jehad-al-Islami; Harakat ul Jihad Islami Bangladesh; Islami Dawat-e-Kafela; IDEK

Description: Designated as an FTO on March 5, 2008, Harakat ul-Jihad-i-Islami/Bangladesh (HUJI-B) was formed in April 1992 by a group of former Bangladeshi Afghan veterans seeking to establish Islamist rule in Bangladesh. In October 2005, Bangladeshi authorities banned the group. The leaders of HUJI-B signed the February 1998 fatwa sponsored by Usama bin Laden that declared U.S. civilians legitimate targets. HUJI-B has connections to al-Qa'ida and Pakistani terrorist groups advocating similar objectives, including HUJI and Lashkar e-Tayyiba (LeT). 
Activities: In December 2008, three HUJI-B members, including HUJI-B leader Mufti Abdul Hannan, were convicted for the May 2004 grenade attack that wounded the British High Commissioner in Sylhet, Bangladesh. In 2011, Bangladeshi authorities formally charged multiple suspects, including Hannan, with the killing of former Finance Minister Shah AMS Kibria in a grenade attack on January 27, 2005. In 2013, Bangladeshi police arrested a group of terrorists, including HUJI-B members, who were preparing attacks on public gatherings and prominent individuals. In 2014, HUJI-B continued its operations; reports at the time suggested that some HUJI-B members may have traveled to Pakistan to receive military training from LeT.

On April 12, 2017, Bangladeshi authorities executed HUJI-B leader Hannan and two associates for the May 2004 grenade attack. In October 2019, Dhaka police arrested three HUJI-B operatives reportedly attempting to revive the group's operations.

Strength: HUJI-B leaders claim that up to 400 of its members are Afghan war veterans; its total membership is unknown.

Location/Area of Operation: Bangladesh and India

Funding and External Aid: HUJI-B funding comes from a variety of sources.

Several international NGOs may have funneled money to HUJI-B.

\section{HARAKAT UL-MUJAHIDEEN}

Aka HUM; Harakat ul-Ansar; HUA; Jamiat ul-Ansar; JUA; al-Faran; al-Hadid; al-Hadith; Harakat ul-Mujahidin; Ansar ul Ummah

Description: Designated as an FTO on October 8, 1997, Harakat ul-Mujahideen (HUM) seeks the annexation of the Indian state of Jammu and Kashmir into Pakistan and the expulsion of Coalition Forces from Afghanistan. In January 2005, HUM's long-time leader Fazlur Rehman Khalil stepped down and was replaced by Dr. Badr Munir. HUM operated terrorist training camps in eastern Afghanistan until Coalition air strikes destroyed them in 2001. In 2003, HUM began using the name Jamiat ul-Ansar; Pakistan banned the group in November 2003.

Activities: HUM has conducted numerous operations against Indian troops and civilian targets in the Indian state of Jammu and Kashmir, as well as in India's northeastern states.

In December 1999, HUM hijacked an Indian airliner, which led to the release of Masood Azhar, an important leader who later founded Jaish-e-Mohammed (JeM). India also released

Ahmed Omar Sheikh as a result of the hijacking. Sheikh was later convicted of the 2002 abduction and murder of U.S. journalist Daniel Pearl.

HUM has conducted attacks targeting Indian interests including the late December 2015 strikes in Handwor and Poonch, which resulted in the deaths of five Indian army personnel. HUM did not claim responsibility for any attacks in 2019.

Strength: After 2000, a significant portion of HUM's membership defected to JeM, and only a small number of cadres are reported to still be active.

Location/Area of Operation: HUM conducts operations primarily in Afghanistan and in the Indian state of Jammu and Kashmir. It operates from Muzaffarabad in Azad Kashmir, and in other cities in Pakistan.

Funding and External Aid: HUM collects donations from wealthy donors in Pakistan. 


\section{HIZBALLAH}

Aka the Party of God; Islamic Jihad; Islamic Jihad Organization; Revolutionary Justice Organization; Organization of the Oppressed on Earth; Islamic Jihad for the Liberation of Palestine; Organization of Right Against Wrong; Ansar Allah; Followers of the Prophet Muhammed; Lebanese Hizballah; Lebanese Hezbollah; LH; Foreign Relations Department; FRD; External Security Organization; ESO; Foreign Action Unit; Hizballah ESO: Hizballah International; Special Operations Branch; External Services Organization; External Security Organization of Hizballah

Description: Hizballah was designated as an FTO on October 8, 1997. Formed in 1982 following the Israeli invasion of Lebanon, the Lebanon-based radical Shia group takes its ideological inspiration from the Iranian revolution and the teachings of the late Ayatollah Khomeini. The group generally follows the religious guidance of the Iranian Supreme Leader, Ali Khamenei. Hizballah is closely allied with Iran and the two often work together on shared initiatives, although Hizballah also occasionally acts independently. Hizballah shares a close relationship with the Syrian regime of Bashar Assad, and like Iran, provides assistance including fighters - to Syrian regime forces in the Syrian conflict.

Activities: Hizballah is responsible for multiple large-scale terrorist attacks, including the 1983 suicide truck bombings of U.S. Embassy Beiruit and the U.S. Marine barracks; the 1984 attack on the U.S. Embassy Beirut annex; and the 1985 hijacking of TWA flight 847, during which U.S. Navy diver Robert Stethem was murdered. Hizballah was also implicated, along with Iran, in the 1992 attacks on the Israeli embassy in Argentina and the 1994 bombing of the Argentine-Israelite Mutual Association in Buenos Aires.

Hizballah assisted Iraq Shia militant and terrorist groups in Iraq, and in January 2007, attacked the Karbala Provincial Joint Coordination Center, killing five American soldiers.

In July 2012, a suspected Hizballah operative was detained by Cypriot authorities for allegedly helping plan an attack against Israeli tourists on the island. On March 21, 2013, a Cyprus court found the operative guilty of charges based on his surveillance activities of Israeli tourists. The group was also responsible for the July 2012 attack on a passenger bus carrying 42 Israeli tourists at the Sarafovo Airport in Bulgaria, near the city of Burgas. The explosion killed five Israelis and one Bulgarian, and injured 32 others.

In May 2013, Hizballah publicly admitted to playing a significant role in the ongoing conflict in Syria, rallying support for the Syrian regime of Bashar Assad. Hizballah's support for Syria's Assad regime continued into 2019.

In May 2013, Nigerian authorities arrested three Hizballah operatives who had stored weapons and a large quantity of ammunition and explosives. In October 2014, Peruvian authorities arrested a Hizballah operative who had been planning to carry out attacks against Israeli and Jewish targets. In May 2015, Cypriot authorities arrested and convicted a Hizballah member after finding 8.2 tons of liquid ammonium nitrate in the basement of a residence in Larnaca. In August 2015, Kuwaiti authorities arrested three Hizballah operatives who had stored weapons and explosives under a residential house. In 2017, Bolivian authorities identified a Hizballah-affiliated warehouse, seizing explosive precursor materials and a VBIED. 
In June 2017, two Hizballah operatives were arrested in the United States. One operative arrested in Michigan had identified the availability of explosives precursors in Panama in 2011 and surveilled U.S. and Israeli targets in Panama as well as the Panama Canal from 2011-2012. Another operative arrested in New York had surveilled U.S. military and law enforcement facilities from 2003-2017.

In September 2018, Brazil arrested a Hizballah financier, and in December 2018, tunnels reportedly built by the group were discovered on Israeli territory along the boundary with Lebanon. In September 2019, Hizballah launched attacks directly on the Israeli military, firing anti-tank missiles targeting an army base and vehicles near the border.

Strength: Hizballah has tens of thousands of supporters and members worldwide.

Location/Area of Operation: Lebanon and Syria

Funding and External Aid: Iran continues to provide Hizballah with most of its funding, training, weapons, and explosives, as well as political, diplomatic, monetary, and organizational aid. Iran's annual financial backing to Hizballah - which in recent years has been estimated at $\$ 700$ million - accounts for the overwhelming majority of the group's annual budget. The Assad regime has provided training, weapons, and diplomatic and political support. Hizballah also receives funding in the form of private donations from some Lebanese Shia diaspora communities worldwide, including profits from legal and illegal businesses. These include smuggling contraband goods, passport falsification, narcotics trafficking, money laundering, and credit card, immigration, and bank fraud.

\section{HIZBUL MUJAHIDEEN}

Aka HM, Hizb-ul-Mujahideen

Description: Hizbul Mujahideen (HM) was designated as an FTO on August 17, 2017. The group was formed in 1989 and is one of the largest and oldest militant groups operating in the Indian state of Jammu and Kashmir. HM is led by Mohammad Yusuf Shah, also known as Syed Salahuddin, and officially supports the liberation of the Indian state of Jammu and Kashmir from Indian control and its accession to Pakistan, although some cadres are pro-independence. The group focuses its attacks on Indian security forces and politicians in the state of Jammu and Kashmir, and has conducted operations jointly with other Kashmiri militants. The group is made up primarily of ethnic Kashmiris.

Activities: HM has claimed responsibility for several attacks in the Indian state of Jammu and Kashmir. In May 2015, HM claimed an attack on Indian security forces in Kupwara that killed three Indian troops, according to the targeted forces. HM launched additional attacks against Indian security forces in 2015 and 2016. On May 1, 2017, HM killed seven people - including five policemen - when it attacked a bank van carrying cash in the Indian state of Jammu and Kashmir. On August 29, 2018, HM reportedly killed four policemen in Shopian district in the Indian state Jammu and Kashmir. On September 21, 2018, HM claimed responsibility for abducting and killing three police officials in the Indian state of Jammu and Kashmir.

In March 2019, Indian officials accused HM of being behind a grenade attack on a Jammu bus stand that killed a teenager and injured 32 others. In June, two Indian soldiers were killed and six others injured when an alleged HM militant attacked their patrol with a VBIED. HM has also 
reportedly been specifically targeting non-locals in the Indian state of Jammu and Kashmir and is suspected by police of having killed five Bengali laborers and a truck driver in October 2019.

Strength: Precise numbers are unknown.

Location/Area of Operation: Jammu and Kashmir

Funding and External Aid: Sources of support are unknown, but HM is suspected to receive some funding from sources in Pakistan as well as from local fundraising.

\section{INDIAN MUJAHEDEEN}

Aka Indian Mujahedeen; Indian Mujahidin; Islamic Security Force-Indian Mujahideen (ISF-IM)

Description: The Indian Mujahedeen (IM) was designated as an FTO on September 19, 2011. The India-based terrorist group is responsible for dozens of bomb attacks throughout India since 2005 and has caused the deaths of hundreds of civilians. IM maintains ties to other terrorist entities including ISIS and Pakistan-based Lashkar e-Tayyiba, Jaish-e-Mohammed, and Harakat ul-Jihad Islami. IM's stated goal is to carry out terrorist actions against Indians for their oppression of Muslims.

Activities: IM is known for carrying out multiple coordinated bombings in crowded areas against economic and civilian targets to maximize terror and casualties. In 2008, IM was responsible for 16 synchronized bomb blasts in crowded urban centers, including an attack in Delhi that killed 30 people and an attack at a local hospital in Ahmedabad that killed 38. In 2010, IM bombed a popular German bakery frequented by tourists in Pune, India; 17 people were killed, and more than 60 people were injured in the attack.

In January 2015, the arrest of three IM militants linked the group to the December 2014 low-intensity blast near a restaurant in Bangalore that killed one woman and injured three others. The arrest also uncovered that the group planned to carry out attacks on India's Republic Day and had provided explosives for attacks in other parts of the country.

In 2016, IM was increasingly linked to ISIS. In May, six IM operatives were identified in an ISIS propaganda video threatening attacks on India. A month later, it was reported that an IM cell linked to ISIS was plotting attacks on multiple targets in Hyderabad and had purchased chemicals to make high-grade explosives for the planned operations. In September 2017, Indian law enforcement uncovered the plans of an IM militant in custody to conduct attacks in India, including targeted killings and bombing a temple in Gaya. IM did not claim responsibility for any attacks in 2019.

Strength: Precise numbers are unknown.

Location/Area of Operation: India

Funding and External Aid: IM is suspected to obtain funding and support from other terrorist organizations, as well as from sources in Pakistan and the Middle East. 


\section{ISLAMIC JIHAD UNION}

Aka Islamic Jihad Group; Islomiy Jihod Ittihodi; al-Djihad al-Islami; Dzhamaat Modzhakhedov; Islamic Jihad Group of Uzbekistan; Jamiat al-Jihad al-Islami; Jamiyat; The Jamaat Mojahedin; The Kazakh Jama'at; The Libyan Society

Description: The Islamic Jihad Union (IJU) was designated as an FTO on June 17, 2005. The group splintered from the Islamic Movement of Uzbekistan in the early 2000s.

Najmiddin Jalolov founded the organization as the Islamic Jihad Group in March 2002, but the group was renamed Islamic Jihad Union in May 2005. Although IJU remains committed to overthrowing the Government of Uzbekistan, today it is active primarily in Afghanistan and, more recently, in Syria, where a number of its members relocated from Afghanistan.

Activities: IJU primarily operates against international forces in Afghanistan and remains a threat to Central Asia. IJU claimed responsibility for attacks in 2004 in Uzbekistan, which targeted police at several roadway checkpoints and at a popular bazaar, killing approximately 47 people, including 33 IJU members, some of whom were suicide bombers. In July 2004, the group carried out near-simultaneous suicide bombings of the Uzbek Prosecutor General's office and the U.S. and Israeli Embassies in Tashkent.

In September 2007, German authorities detained three IJU operatives, including two German converts, disrupting the group's plans to attack targets in Germany - including Ramstein Airbase where the primary targets would be U.S. diplomats, soldiers, and civilians.

In 2013, two IJU videos showed attacks against an American military base in Afghanistan and an IJU sniper shooting an Afghan soldier.

According to statements and photos released by the group, IJU participated in the five-month long 2015 Taliban siege of Kunduz city. At least 13 police officers were killed in the attacks, and hundreds of civilians were killed. In August 2015, IJU pledged allegiance to the then newly appointed Taliban leader Mullah Mansour.

In 2017, IJU released a video showing its militants using assault rifles and rocket-propelled grenades to fight Afghan troops in late 2016. IJU released a second video in April 2018 showing a joint raid with the Taliban in northern Afghanistan. The video, dated October 2017, shows a night clash with Afghan forces. In 2019, the United Nations confirmed that IJU was operating inside Syria under control of al-Nusra Front.

Strength: IJU consists of 100 to 200 members.

Location/Area of Operation: Afghanistan, Syria, Uzbekistan, Turkey, and Europe

Funding and External Aid: Sources of funding are unknown.

\section{ISLAMIC MOVEMENT OF UZBEKISTAN}

\section{Aka IMU}

Description: Designated as an FTO on September 25, 2000, the Islamic Movement of Uzbekistan (IMU) seeks to overthrow the Uzbek government and establish an Islamic state. For most of the past decade, however, the group has recruited members from other Central Asian states and Europe. Despite its stated objective to set up an Islamic state in Uzbekistan, the group 
primarily operates along the Afghanistan-Pakistan border and in northern Afghanistan, where it fights against international forces. Several IMU members are also suspected of having traveled to Syria to fight with terrorist groups.

The IMU has had a decade-long relationship with al-Qa'ida (AQ), the Taliban, and Tehrik-e Taliban Pakistan. Top IMU leaders have integrated themselves into the Taliban's shadow government in Afghanistan's northern provinces.

In August 2015, IMU leader Usman Ghazi publicly announced the group's shift of allegiance to ISIS. Numerous IMU members, including possibly Ghazi himself, were subsequently reported to have been killed as a result of hostilities between ISIS and the IMU's former Taliban allies.

Activities: Since the beginning of Operation Enduring Freedom, the IMU has been predominantly focused on attacking international forces in Afghanistan. In late 2009, NATO forces reported an increase in IMU-affiliated FTFs in Afghanistan. In 2010, the IMU claimed responsibility for the September 19 ambush that killed 25 Tajik troops in Tajikistan.

On June 8, 2014, IMU claimed responsibility for an attack on Karachi's international airport that resulted in the deaths of at least 39 people.

Throughout 2015, the IMU actively threatened the Afghan government, primarily in the northern part of the country. In April 2015, the group released a video showing IMU members beheading an individual they claimed to be an Afghan soldier and threatened to behead Hazara (a historically persecuted ethnic group in Afghanistan) hostages, in supposed retaliation for the Afghan security forces capture of several female IMU members. In 2016, Uzbek refugee Fazliddin Kurbanov was sentenced by a U.S. federal court to 25 years in prison for planning a bomb attack in Idaho. Kurbanov had been in online contact with members of IMU, seeking advice on how to make explosives and discussing attacking U.S. military bases.

In June 2016, a faction of the IMU announced its continued commitment to the Taliban and AQ, marking a split with its leader Ghazi and the rest of the group, which announced its loyalty to ISIS in 2015 and has since cooperated with Islamic State's Khorasan Province. IMU did not claim responsibility for any attacks in 2019.

Strength: Precise numbers are unknown.

Location/Area of Operation: Afghanistan, Pakistan, Syria, Central Asia, and Turkey

Funding and External Aid: The IMU receives support from a large Uzbek diaspora, terrorist organizations, and donors from Europe, Central and South Asia, and the Middle East.

\section{ISLAMIC REVOLUTIONARY GUARD CORPS}

Aka IRGC; The Iranian Revolutionary Guards; IRG; The Army of the Guardians of the Islamic Revolution; AGIR; Pasdarn-e Enghelab-e Islami; Sepah-e Pasdaran Enghelab Islami; Sepah-e Pasdaran-e Enghelab-e Eslami; Sepah-e Pasdaran-e Enqelab-e Eslami; Pasdaran-e Inqilab; Revolutionary Guards; Revolutionary Guard; Sepah; Pasdaran; Sepah Pasdaran; Islamic Revolutionary Corps; Islamic Revolutionary Guards Corps; Iran's Revolutionary Guard Corps; Islamic Revolutionary Guards; Iran's Revolutionary Guards; Army of the Guardians of the Islamic Revolution. 
Description: Designated as an FTO on April 15, 2019, the Islamic Revolutionary Guard Corps (IRGC), part of Iran's official military, has played a central role in Iran's use of terrorism as a key tool of Iranian statecraft since its inception 40 years ago. The IRGC has been directly involved in terrorist plotting; its support for terrorism is foundational and institutional, and it has killed U.S. citizens.

The IRGC was founded in 1979 and since then has gained a substantial role in executing Iran's foreign policy and wields control over vast segments of the economy. The IRGC's ties to nonstate armed groups in the region, such as Hizballah in Lebanon, help Iran compensate for its relatively weak conventional military forces. Answering directly to the supreme leader, the corps is also influential in domestic politics, and many senior officials have passed through its ranks.

The IRGC is composed of five primary branches: the IRGC Ground Forces, IRGC Air Force, IRGC Navy, the Basij, and the IRGC-Qods Force (IRGC-QF).

Activities: The IRGC - most prominently through its Qods Force (QF) - directs and carries out a global terrorist campaign. The IRGC-QF in 2011 plotted a brazen terrorist attack against the Saudi Ambassador to the U.S. on American soil. In 2012, IRGC-QF operatives were arrested in Turkey and Kenya for plotting attacks. An IRGC operative was convicted in March 2017 of espionage for a foreign intelligence service; he had been surveilling a German-Israeli group. In January 2018, Germany uncovered ten IRGC operatives involved in a terrorist plot in Germany. In September 2018, a U.S. federal court found Iran and the IRGC liable for the 1996 Khobar Towers bombing which killed 19 Americans. The QF is active in Syria in support of the Assad regime.

The IRGC-QF is Iran's primary mechanism for cultivating and supporting terrorist groups abroad. The IRGC continues to provide financial and other material support, training, technology transfer, advanced conventional weapons, guidance, or direction to a broad range of terrorist organizations, including Hizballah, Kata'ib Hizballah in Iraq, al-Ashtar Brigades in Bahrain, and other terrorist groups in Syria and around the Gulf. Iran also provides up to $\$ 100$ million annually in combined support to Palestinian terrorist groups, including Hamas, PIJ, and the Popular Front for the Liberation of Palestine-General Command.

Strength: The IRGC has upwards of 125,000 troops under its command.

Location/Area of Operation: Iran, Iraq, Syria, Europe, and the Gulf

Funding and External Aid: The IRGC-QF continues to engage in large-scale illicit financing schemes and money laundering to fund its malign activities. In 2017, the IRGC-QF engineered a plot to produce counterfeit currency by deceiving European suppliers to procure advanced

printing machinery and other necessary materials. It then printed counterfeit Yemeni bank notes, which were used to support its destabilizing activities in Yemen.

\section{ISLAMIC STATE OF IRAQ AND SYRIA}

Aka al-Qa'ida in Iraq; al-Qa'ida Group of Jihad in Iraq; al-Qa'ida Group of Jihad in the Land of the Two Rivers; al-Qa'ida in Mesopotamia; al-Qa'ida in the Land of the Two Rivers; al-Qa'ida of Jihad in Iraq; al-Qa'ida of Jihad Organization in the Land of the Two Rivers; al-Qa'ida of the Jihad in the Land of the Two Rivers; al-Tawhid; Jam'at al-Tawhid Wa'al-Jihad; Tanzeem 
Qa'idat al Jihad/Bilad al Raafidaini; Tanzim Qa'idat al-Jihad fi Bilad al-Rafidayn; The Monotheism and Jihad Group; The Organization Base of Jihad/Country of the Two Rivers; The Organization Base of Jihad/Mesopotamia; The Organization of al-Jihad's Base in Iraq; The Organization of al-Jihad's Base in the Land of the Two Rivers; The Organization of al-Jihad's Base of Operations in Iraq; The Organization of al-Jihad's Base of Operations in the Land of the Two Rivers; The Organization of Jihad's Base in the Country of the Two Rivers; al-Zarqawi Network; Islamic State of Iraq; Islamic State of Iraq and al-Sham; Islamic State of Iraq and Syria; ad-Dawla al-Islamiyya fi al-'Iraq wa-sh-Sham; Daesh; Dawla al Islamiya; Al-Furqan Establishment for Media Production; Islamic State; ISIL; ISIS; Amaq News Agency; Al Hayat Media Center; Al-Hayat Media Center; Al Hayat

Description: Al-Qa'ida in Iraq (AQI) was designated as an FTO on December 17, 2004. In the 1990s, Jordanian militant Abu Mus'ab al-Zarqawi organized a terrorist group called al-Tawhid wal-Jihad to oppose the presence of U.S. and western military forces in the Middle East as well as the West's support for, and the existence of, Israel. In late 2004, Zarqawi joined al-Qa'ida (AQ) and pledged allegiance to Usama bin Laden. At that time, his group became known as al-Qa'ida in Iraq (AQI). Zarqawi led the group in Iraq during Operation Iraqi Freedom to fight against U.S. and Coalition Forces until his death in June 2006.

In October 2006, AQI publicly renamed itself the Islamic State in Iraq. In 2013, it adopted the moniker ISIS to express its regional ambitions as it expanded operations to include the Syrian conflict. ISIS was led by Abu Bakr al-Baghdadi, who declared an Islamic caliphate in June 2014, until he was killed on October 27, 2019. In October 2017, the U.S. military fighting with local Syrian allies announced the liberation of Raqqa, the self-declared capital of ISIS's so-called "caliphate." In December 2017, then Iraqi Prime Minister Haidar al-Abadi announced the territorial defeat of ISIS in Iraq. In September 2018, the Syrian Democratic Forces, with support from the U.S.-led Global Coalition to Defeat ISIS began a final push to oust ISIS fighters from the lower Middle Euphrates River Valley in Syria. March 2019 marked the full territorial defeat of ISIS's so-called caliphate.

Activities: ISIS has conducted numerous high-profile attacks, including IED attacks against U.S. military personnel and Iraqi infrastructure, videotaped beheadings of U.S. citizens, suicide bombings against both military and civilian targets, and rocket attacks. ISIS perpetrated these attacks using foreign, Iraqi, and Syrian operatives. In 2014, ISIS was responsible for most of the 12,000 Iraqi civilian deaths that year. ISIS is heavily involved in the fighting in Syria, and has participated in numerous kidnappings of civilians, including aid workers and journalists. In 2015 and 2016, ISIS claimed responsibility for several large-scale attacks in Iraq and Syria. In July 2016, ISIS claimed responsibility for a car bombing at a popular shopping center in Baghdad that killed nearly 300 people, making it the single deadliest bombing in Iraq's capital city since 2003 .

ISIS continued its attacks throughout 2017. In February 2017, ISIS killed 56 people in a series of attacks in Baghdad. In early April, the group killed 33 Syrians in eastern Syria, and on the same day, killed another 22 people in Tikrit, Iraq. In June, ISIS gunmen and suicide bombers killed more than a dozen people in two separate attacks in Tehran, including an attack inside the Parliament building. In September, ISIS killed over 80 people in Nasiriyah, Iraq, an area frequented by Shia Muslims on pilgrimage. 
Since at least 2015, the group has integrated local children and children of FTFs into its forces and used them as executioners and suicide attackers. ISIS has systematically prepared child soldiers in Iraq and Syria using its education and religious infrastructure as part of its training and recruitment of members. Further, since 2015, ISIS abducted, raped, and abused thousands of women and children, some as young as eight years old. Women and children were sold and enslaved, distributed to ISIS fighters as spoils of war, forced into marriage and domestic servitude, or subjected to physical and sexual abuse. For further information, refer to the 2019 Trafficking in Persons Report.

ISIS also directs, enables, and inspires individuals to conduct attacks on behalf of the group around the world, including in the United States and Europe. In November 2015, ISIS carried out a series of coordinated attacks in Paris, France, including at a rock concert at the Bataclan concert hall, killing about 130 people and injuring more than 350 others; 23 year-old U.S. citizen Nohemi Gonzalez was among the dead. In March 2016, ISIS directed two simultaneous attacks in Brussels, Belgium - one at the Zaventem Airport and the other at a metro station. The attacks killed 32 people, including four U.S. citizens, and injured more than 250 people. In June 2016, a gunman who pledged allegiance to ISIS killed 49 individuals and injured 53 others at the Pulse nightclub in Orlando, Florida. In July 2016, ISIS claimed an attack in which a terrorist driving a cargo truck attacked a crowd in Nice, France, during Bastille Day celebrations, resulting in 86 deaths, including three U.S. citizens. In December 2016, ISIS claimed responsibility for a truck attack on a crowded Christmas market in Berlin, Germany, that killed 12 people and injured 48 others.

In March 2017, ISIS claimed responsibility for a terrorist attack on London's Westminster Bridge when a man drove his car into pedestrians and stabbed others, killing five people. In early April 2017, a man who claimed to be a member of ISIS drove a truck into a crowded shopping center in Stockholm, Sweden, killing five and injuring many more. In May 2017, ISIS claimed a suicide bombing in Manchester, England, that killed 22 people outside of a live concert.

In July 2018, ISIS attacked the city of Suweida and nearby towns and villages in southwestern Syria, conducting multiple suicide bombings and simultaneous raids in a brutal offensive, killing more than 200 people.

In January 2019, ISIS claimed responsibility for the suicide bombing of a restaurant in Manbij, Syria that killed 19 people, including four Americans. That same month, ISIS reportedly launched a missile attack that seriously wounded two British commandos in eastern Syria. On Easter Sunday 2019, over 250 people were killed in Sri Lanka when ISIS inspired terrorists carried out coordinated suicide bombings at multiple churches and hotels. In August, ISIS claimed responsibility for killing a U.S. service member while he was participating in a combat operation in Ninawa Province, Iraq. In November, ISIS claimed responsibility for a stabbing attack near the London Bridge in which a man killed two people and injured three others. Also in November, ISIS claimed responsibility for a November 6 attack on a border post in Tajikistan that killed four Tajik service members and 15 militants.

Strength: Estimates suggest ISIS fighters in Iraq and Syria number between 11,000 and 18,000, including several thousand FTFs.

Location/Area of Operation: Iraq and Syria, with branches and networks around the world. 
Funding and External Aid: ISIS received most of its funding from a variety of criminal activities in Iraq and Syria. Criminal activities included extortion of civilian economies, smuggling oil, and robberies. ISIS also maintains stockpiles of as much as hundreds of millions of dollars scattered across Iraq and Syria it looted during its occupation of those countries in 2013 to 2019. ISIS continues to rely on trusted courier networks and money services businesses to move its financial resources within and outside of Iraq and Syria. Before ISIS's territorial defeat, targeted counterterrorism operations and airstrikes served to sever critical financial networks, reduce the group's cash reserves in Iraq and Syria, and degrade ISIS's ability to exploit local resources such as oil. The territorial defeat of ISIS which eliminated its control of territory in Syria in 2019 reduced ISIS's ability to generate, hold, and transfer its financial assets. Despite this, ISIS continues to generate revenue from criminal activities through its many clandestine networks in Iraq and Syria, and provides significant financial support and guidance to its network of global branches and affiliates.

ISIS has increased its presence outside the conflict zone in Iraq and Syria. In particular, ISIS core creates financial and logistical hubs in Central and East Africa, North Africa, and West Africa. ISIS also announced that the group had established two new branches in Pakistan and India.

\section{ISIS-BANGLADESH}

Aka Caliphate in Bangladesh, Caliphate's Soldiers in Bangladesh, Soldiers of the Caliphate in Bangladesh, Khalifa's Soldiers in Bengal, Islamic State Bangladesh, Islamic State in Bangladesh, ISB, ISISB, Abu Jandal al-Bangali, Neo-JMB, New JMB, Neo-Jammat-ul Mujahadeen-Bangladesh

Description: ISIS-Bangladesh was designated as an FTO on February 28, 2018. Created in 2014, ISIS-Bangladesh has described itself as ISIS's official branch in Bangladesh and was born out of ISIS's desire to expand its campaign to the Indian Subcontinent. Coinciding with the announcement of the caliphate in Iraq and Syria, a group of Bangladeshi nationals pledged allegiance to ISIS and vowed to organize Bengali Muslims under the leadership of then-ISIS leader, Abu Bakr al-Baghdadi.

Activities: In September 2015, gunmen belonging to ISIS-Bangladesh shot and killed an Italian aid worker in Dhaka. In December 2015, ISIS-Bangladesh claimed responsibility for injuring 10 people during a Christmas Day suicide attack at a mosque packed with Ahmadi Muslims. In July 2016, the group claimed responsibility for an assault on the Holey Artisan Bakery in Dhaka that killed 22 people, including one American. In March 2017, ISIS-Bangladesh claimed responsibility for twin explosions that targeted a crowd in Sylhet, Bangladesh, killing six people.

In April and May 2019, ISIS-Bangladesh claimed responsibility for two explosions in Dhaka that injured four police officers and two civilians. In August, ISIS-Bangladesh claimed responsibility for a small bomb thrown at a Bangladeshi minister in Dhaka, which injured two police officers. In September, the group claimed responsibility for an explosion outside Awami League office in Khulna.

Strength: ISIS-Bangladesh has several hundred armed supporters.

Location/Area of Operation: Bangladesh 
Funding and External Aid: Although ISIS-Bangladesh's sources of funding are largely unknown, the group does receive some support from ISIS.

\section{ISIS-GREATER SAHARA}

Aka ISIS in the Greater Sahara (ISIS-GS); Islamic State in the Greater Sahel (ISGS); Islamic State in the Greater Sahara; Islamic State of the Greater Sahel; ISIS in the Greater Sahel; ISIS in the Islamic Sahel

Description: ISIS in the Greater Sahara (ISIS-GS) was designated as an FTO on May 23, 2018. ISIS-GS emerged when leader Adnan Abu Walid al-Sahrawi and his followers split from al-Murabitoun. Al-Sahrawi first pledged allegiance to ISIS in May 2015, which was acknowledged by ISIS in October 2016.

Activities: In September 2016, ISIS-GS claimed responsibility for an attack on a gendarmerie post in Markoye, Burkina Faso, that killed two people. In October 2016, ISIS-GS claimed responsibility for an attack on a military post in Intangom, Burkina Faso, that killed three Burkinabe soldiers.

In October 2017, ISIS-GS claimed responsibility for an attack on a joint U.S.-Nigerien patrol in the region of Tongo, Niger, which killed four U.S. soldiers and five Nigerien soldiers. In 2018, ISIS-GS was reportedly involved in numerous skirmishes and attacks in Mali and Niger, including those in May that targeted French troops and civilians. In 2019, ISIS-GS continued to intensify their rate of attacks, including an attack in November on a Malian military base that killed 54 soldiers.

Strength: Precise numbers are unknown.

Location/Area of Operation: Mali, Niger, and Burkina Faso

Funding and External Aid: Sources of funding are unknown.

\section{ISLAMIC STATE'S KHORASAN PROVINCE}

Aka Islamic State's Khorasan Province; ISIS Wilayat Khorasan; ISIL's South Asia Branch; South Asian Chapter of ISIL

Description: Islamic State's Khorasan Province (ISIS-K) was designated as an FTO on January 14, 2016. The group is based in Afghanistan, conducts operations in Afghanistan and Pakistan, and is composed primarily of former members of Tehrik-e Taliban Pakistan, the Afghan Taliban, and the Islamic Movement of Uzbekistan. ISIS-K's senior leadership has pledged allegiance to then-ISIS leader Abu Bakr al-Baghdadi, which was accepted in late January 2015. The group has carried out suicide bombings, small arms attacks, and kidnappings in Afghanistan against civilians and Afghan National Security and Defense Forces. ISIS-K has also claimed responsibility for attacks on civilians and government officials in Pakistan.

Activities: In January 2016, ISIS-K claimed a strike on a Pakistani consulate in Afghanistan, resulting in the deaths of seven Afghan security personnel. In July 2016, the group conducted a bomb attack at a peaceful protest in Kabul, Afghanistan, that killed an estimated 80 people and wounded another 230. In August 2016, ISIS-K claimed a shooting and suicide bombing at a hospital in Quetta, Pakistan, targeting lawyers, which killed 94. The group also claimed 
responsibility for a November 2016 suicide bombing at the Shah Noorani Shrine in Balochistan province, Pakistan, killing more than 50 people.

In July 2017, ISIS-K attacked the Iraqi Embassy in Kabul, killing two people, and bombed a mosque in western Afghanistan, killing 29 people and injuring 60 others. Between October and December of 2017, ISIS-K claimed responsibility for several deadly attacks in Kabul, including those targeting a television station, a Shia cultural center, and an Afghan intelligence office near the U.S. embassy.

ISIS-K also claimed multiple attacks in Pakistan in 2017, including an attack on a Sufi shrine in Sindh province in February that killed at least 88 people, an attack on a church in Quetta that killed at least nine people, and a July attack on an election rally in Balochistan province that killed 149 people. In September 2018, ISIS-K claimed responsibility for a double suicide bombing in a Shiite majority neighborhood in Kabul, leaving more than 20 dead and 70 injured.

In April 2019, ISIS-K claimed responsibility for an attack at the Ministry of Communications in Kabul, killing seven people. In August 2019, ISIS-K claimed responsibility for a suicide bombing at a wedding hall in a Shiite minority neighborhood in Kabul, killing 80 people and injuring 154 others. In October 2019, an ISIS-K bombing of a mosque in Nangarhar province killed at least 70 people. In November 2019, ISIS-K suffered a series of major defeats and lost much of its territory in Nangahar in the face of attacks by both the coalition and Taliban forces.

Strength: ISIS-K is estimated to have approximately 1,000 fighters.

Location/Area of Operation: Afghanistan, Pakistan, and Central Asia

Funding and External Aid: ISIS-K receives some funding from ISIS. Additional funds come from illicit criminal commerce, taxes, and extortion on the local population and businesses.

\section{ISLAMIC STATE OF IRAQ AND THE LEVANT-LIBYA}

Aka Islamic State of Iraq and the Levant-Libya; Islamic State of Iraq and the Levant in Libya; Wilayat Barqa; Wilayat Fezzan; Wilayat Tripolitania; Wilayat Tarablus; Wilayat al-Tarabulus

Description: The Islamic State of Iraq and the Levant-Libya (ISIL-Libya) was designated as an FTO on May 20, 2016. In 2014, then-ISIS leader Abu Bakr al-Baghdadi dispatched a group of ISIS operatives from Syria to Libya to establish a branch of the terrorist group. In October 2014, several hundred operatives set up a base in Darnah, and the following month, Baghdadi formally established the branch after announcing he had accepted oaths of allegiance from fighters in Libya.

Activities: Since becoming established, ISIS-Libya has carried out multiple attacks throughout Libya and has threatened to expand ISIS's presence into other countries in Africa.

In January 2015, ISIL-Libya claimed responsibility for a suicide attack on a luxury hotel in Tripoli, Libya, that killed eight people, including a U.S. contractor.

In February 2015, ISIL-Libya released a propaganda video showing the murder of 21 Egyptian Coptic Christians who had been kidnapped from Sirte, Libya, in two separate incidents in December 2014 and January 2015. That same month, ISIL-Libya claimed responsibility for bomb attacks against a petrol station, a police station, and the home of parliamentary speaker 
Agila Salah in the town of al-Qubbah. These attacks killed more than 40 people and wounded dozens of others.

In 2016, ISIL-Libya expanded operations into Libya's oil crescent, launching attacks on some of the country's largest oil installations: burning oil tanks, killing dozens, and forcing facilities to shut down operations. In December, Libyan forces drove ISIL-Libya from its main stronghold in Sirte and into the desert areas and neighboring cities.

In May 2018, ISIL-Libya claimed responsibility for an attack on Libya's electoral commission headquarters in Tripoli that killed 14 people. In September, ISIL-Libya claimed responsibility for a suicide attack on Libya's National Oil Company headquarters that left two dead and 10 others wounded. In October, ISIL-Libya was implicated in an attack on a town in central Libya that resulted in five people killed and 10 others kidnapped. In December, ISIL-Libya claimed responsibility for an attack on the Ministry of Foreign Affairs that killed three people.

In May 2019, ISIL-Libya claimed responsibility for a number of attacks on the Libyan National Army (LNA). These included a dawn assault on a military training camp in the southern city of Sebha which killed at least nine soldiers and an attack on the town of Zillah in which three soldiers were killed and four captured.

Strength: ISIL-Libya is estimated to have fewer than 500 fighters.

\section{Location/Area of Operation: Libya}

Funding and External Aid: ISIL-Libya's funding comes from a variety of sources, including criminal activity, such as smuggling and extortion, and external funding. The group also receives support from ISIS.

\section{ISIS-PHILIPPINES}

Aka ISIS in the Philippines; ISIL Philippines; ISIL in the Philippines; IS Philippines; ISP; Islamic State in the Philippines; Islamic State of Iraq and Syria in South-east Asia; Dawlatul Islamiyah Waliyatul Masrik (DIWM); Dawlatul Islamiyah Waliyatul Mashriq; IS East Asia Division; ISIS Branch in the Philippines; ISIS’ Philippines province

Description: ISIS-Philippines (ISIS-P) was designated as an FTO on February 28, 2018. In July 2014, militants in the Philippines pledged allegiance to ISIS in support of ISIS's efforts in the region under the command of now-deceased leader Isnilon Hapilon. Hatib Hajan Sawadjaan is the current leader of ISIS-P, and the organization has ties to elements of the Abu Sayyaf Group.

Activities: In May 2016, ISIS-P claimed responsibility for an attack on Basilan Island, which killed one solider and injured another. In 2017, ISIS-P participated in five months of fighting in Marawi that claimed more than 1,000 lives and forced more than 300,000 residents to flee the area. In July 2018, ISIS-P claimed responsibility for a suicide bomb attack on a military checkpoint in Basilan that killed 10 people. In January 2019, ISIS-P claimed responsibility for the Jolo cathedral bombing in Sulu, a complex suicide attack carried out by an Indonesian couple during mass, killing 23 people and wounding more than 100 others.

Strength: ISIS-P is estimated to have a small cadre of fighters in the southern Philippines, but exact numbers are unknown. 
Location/Area of Operation: The Philippines

Funding and External Aid: ISIS-P receives financial assistance from ISIS in Syria and receives funds from local extortion and kidnapping-for-ransom groups.

\section{ISLAMIC STATE-SINAI PROVINCE}

Aka Ansar Bayt al-Maqdis; Ansar Jerusalem; Supporters of Jerusalem; Ansar Bayt al-Maqdes; Ansar Beit al-Maqdis; Islamic State-Sinai Province; Islamic State in the Sinai; Jamaat Ansar Beit al-Maqdis fi Sinaa; Sinai Province; Supporters of the Holy Place; The State of Sinai; Wilayat Sinai

Description: Originally designated as an FTO on April 9, 2014, Ansar Bayt al-Maqdis (ABM, as it was known then) rose to prominence in 2011 following the uprisings in Egypt. In November 2014, ABM officially declared allegiance to ISIS. In September 2015, the Department of State amended ABM's designation to add the aliases ISIL Sinai Province and Islamic State-Sinai Province (ISIS-SP), among others.

Activities: Prior to pledging allegiance to ISIS, ABM claimed responsibility for numerous attacks against Israeli and Egyptian interests from 2012 through 2014, including attacks on Israeli economic and military assets, as well as attacks on the Egyptian military and tourist sectors. On November 4, 2015, ISIS-SP released an audio recording in which it claimed responsibility for the October 31 bombing of a Russian passenger plane carrying 231 people from the Egyptian resort town of Sharm el-Sheikh to St. Petersburg, Russia. All 224 passengers and seven crew members were killed.

On August 5, 2015, ISIS-SP claimed responsibility for the July 22 abduction and killing of Croatian citizen Tomislav Salopek.

Throughout 2016, ISIS-SP carried out numerous attacks in the Sinai, including a January double bombing that killed two Egyptian policemen and two military officers. The group was responsible for a July 2016 wide-scale coordinated attack on several military checkpoints that reportedly killed more than 50 people. On December 11, 2016, an attack on St. Mark's Cathedral, a Coptic Christian church in Cairo, killed 29 people.

In 2017, ISIS-SP attacked two Coptic Christian churches on Palm Sunday (April 9), killing 30 people at St. George's Church in Tanta and killing 17 people at St. Mark's Church in Alexandria. In May 2017, the group's attack on a bus of pilgrims en route to St. Samuel the Confessor, a Coptic monastery near Minya, killed 29 people. In September 2017, ISIS-SP attacked an Egyptian police convoy in an ambush that killed 18 soldiers. In November 2017, an attack on the al-Rawda mosque in North Sinai - Egypt's deadliest in modern history - killed more than 300 individuals at prayer. While the attack was unclaimed, press reported the Egyptian Prosecutor General's office as attributing the attack to ISIS-SP and alleging that attackers carried an ISIS flag. The group's December 2017 attack on St. Mina, a Coptic Christian church near Cairo, killed 11 people.

ISIS-SP attacked an Egyptian army base in April 2018 and attacked an Egyptian police checkpoint in December 2018, killing 15 soldiers in each attack. On November 2, 2018, the group's attack on a bus of pilgrims traveling from St. Samuel the Confessor killed seven and wounded 14 others. 
In 2019, ISIS-SP claimed responsibility for multiple attacks on Egyptian police and army checkpoints in the Sinai. In February, ISIS-SP killed 15 Egyptian soldiers and killed eight Egyptian policemen in June. In July, ISIS-SP claimed responsibility for beheading four civilians and for a suicide bombing in North Sinai that killed a civilian and a member of the security forces.

Strength: ISIS-SP is estimated to have between 800 and 1,200 fighters in the Sinai Peninsula and affiliated cells in the Nile Valley.

\section{Location/Area of Operation: Egypt}

Funding and External Aid: Although the sources of ISIS-SP's funding are largely unknown, there are indications that it may receive funding from ISIS in Syria.

\section{ISIS-WEST AFRICA}

Aka Islamic State West Africa Province; ISISWAP; Islamic State of Iraq and the Levant-West Africa; ISIL-WA; Islamic State of Iraq and Syria West Africa Province; ISIS West Africa Province; ISIS West Africa; ISIS-WA

Description: ISIS-West Africa (ISIS-WA) was designated as an FTO on February 28, 2018. In March 2015, a faction of Boko Haram pledged allegiance to ISIS in an audiotape message. ISIS accepted the group's pledge and the group began calling itself ISIS-West Africa. In August 2016, ISIS announced that Abu Musab al-Barnawi was to become the new leader of ISIS-WA.

Activities: ISIS-WA has been responsible for numerous attacks in Nigeria and the Lake Chad region since 2016. In January 2017, ISIS-WA conducted a midnight attack against Nigerian troops in the village of Kamuya, killing three Nigerian soldiers.

In February 2018, ISIS-WA abducted a Christian student in Nigeria and in March 2018, the group kidnapped three aid workers during an attack that killed dozens of other people. ISIS-WA killed one of the three aid workers in September 2018 and another in October. In November 2018, ISIS-WA claimed responsibility for five attacks in Chad and Nigeria that resulted in 118 deaths.

In February 2019, ISIS-WA attacked the convoy of the then-Governor of Borno State as it drove from the capital of Maiduguri to a town near Nigeria's border with Cameroon, killing as many as 10. In May 2019, ISIS-WA claimed responsibility for two attacks in western Niger, ambushing Niger Army soldiers in Tongo resulting in 28 deaths, while also attacking Niger security forces near the Koutoukale prison that killed one soldier.

In July 2019, ISIS-WA fighters launched an attack against a military base near Baga in the Lake Chad area, killing 20 Nigerian and five Chadian soldiers. Also in July, ISIS-WA attacked a convoy of Action Against Hunger (AAH) and Nigerian health ministry employees in Borno. One AAH driver was killed, while one AAH staff member, two drivers, and three health ministry workers remained missing, reportedly taken as hostages. On September 25, media reported ISIS-WA said it executed one of the missing aid workers. On December 13, ISIS-WA said it killed four of the five remaining hostages. On December 26, ISIS-WA released a video showing the execution of 11 reported Christians and claimed the killings were revenge for the killing of ISIS leader Abu Bakr al-Baghdadi. 
Strength: ISIS-WA has an estimated 3,500 members.

Location/Area of Operation: Nigeria and the greater Lake Chad region

Funding and External Aid: ISIS-WA receives funding from local sources, the capture of military supplies, taxes, and kidnapping-for-ransom payments.

\section{JAMA'AT NUSRAT AL-ISLAM WAL-MUSLIMIN}

Aka Jamaat Nosrat al-Islam wal-Mouslimin; Group for the Support of Islam and Muslims; Group to Support Islam and Muslims; GSIM; GNIM; Nusrat al-Islam wal-Muslimeen

Description: Jama'at Nusrat al-Islam wal-Muslimin (JNIM) was designated as an FTO on September 6, 2018. JNIM has described itself as al-Qa'ida's official branch in Mali and has claimed responsibility for numerous attacks and kidnappings since its formation in March 2017. In 2017, the Sahara Branch of al-Qa'ida in the Islamic Maghreb, al-Murabitoun, Ansar al-Dine, and the Macina Liberation Front came together to form JNIM. JNIM is led by Iyad ag Ghali. JNIM's second in command, Ali Maychou, was killed in October 2019.

Activities: In June 2017, JNIM carried out an attack at a resort frequented by Westerners outside of Bamako, Mali, and was responsible for the large-scale coordinated attacks in Ouagadougou, Burkina Faso, on March 2, 2018.

In June 2018, JNIM claimed responsibility for a suicide attack against an African Coalition base in Mali that killed at least six people. In July 2018, JNIM claimed responsibility for a suicide bombing in Gao, Mali, which targeted a French military patrol and killed several civilians. In November 2018, JNIM claimed responsibility for the detonation of a truck bomb in a residential complex in Gao, killing three and injuring 30.

In January 2019, JNIM claimed responsibility for an attack against a UN base in Northern Mali, killing 10 Chadian peacekeepers and wounding 25 others. In April, JNIM claimed responsibility for an assault on a Malian military base, killing 11 soldiers. In September, JNIM detonated a landmine under a passenger bus in central Mali, killing 14 civilians and injuring another 24 .

Strength: JNIM is estimated to have between 1,000 and 2,000 fighters.

Location/Area of Operation: Mali, Burkina Faso, and Niger

Funding and External Aid: JNIM receives funding through kidnapping-for-ransom and extortion and from smugglers and traffickers who pay a tax in exchange for permission and safe transit through JNIM-controlled trafficking routes in Mali.

\section{JAMA'ATU ANSARUL MUSLIMINA FI BILADIS-SUDAN}

Aka Ansaru; Ansarul Muslimina Fi Biladis Sudan; Vanguards for the Protection of Muslims in Black Africa; JAMBS; Jama'atu Ansaril Muslimina Fi Biladis Sudan

Description: Designated as an FTO on November 14, 2013, Jama'atu Ansarul Muslimina Fi Biladis-Sudan (Ansaru) publicly splintered from Boko Haram in January 2012. Since its inception, Ansaru has targeted civilians, including Westerners, and Nigerian government and security officials. Ansaru purportedly aims to defend Muslims throughout Africa by fighting 
against the Nigerian government and international interests. Ansaru claims to identify with Boko Haram's objectives and struggle, but has criticized the group for killing fellow Muslims.

Activities: In November 2012, Ansaru raided a police station in Abuja, killing Nigerian police officers and freeing detained terrorists from prison. Ansaru has also carried out multiple kidnapping operations targeting civilians. In late 2012, Ansaru kidnapped a French engineer allegedly in response to French involvement in Mali. In early 2013, Ansaru kidnapped and subsequently killed seven international construction workers.

On April 4, 2016, the Nigerian army announced the capture of Ansaru leader Khalid al-Barnawi. Ansaru did not publicly claim responsibility any attacks in 2019, but in October 2019, Ansaru announced the creation of a new media outlet for the group.

Strength: Precise numbers are unknown; however, given its narrower scope of operations, Ansaru's membership is estimated to be much smaller than that of Boko Haram.

Location/Area of Operation: Nigeria

Funding and External Aid: Sources of funding are unknown.

\section{JAISH-E-MOHAMMED}

Aka Army of Mohammed; Mohammed's Army; Tehrik ul-Furqaan; Khuddam-ul-Islam; Khudamul Islam; Kuddam e Islami; Jaish-i-Mohammed

Description: Pakistan-based Jaish-e-Mohammed (JeM) was designated as an FTO on December 26, 2001. JeM was founded in early 2000 by former senior Harakat ul-Mujahideen leader Masood Azhar. The group aims to annex the Indian state of Jammu and Kashmir to Pakistan and expel international forces from Afghanistan. JeM has openly declared war against the United States.

Activities: JeM continues to operate openly in parts of Pakistan, conducting fatal attacks in the region, despite the country's 2002 ban on its activities. JeM has claimed responsibility for several suicide car bombings in the Indian state of Jammu and Kashmir, including an October 2001 suicide attack on the Jammu and Kashmir legislative assembly building in Srinagar that killed more than 30 people. The Indian government publicly implicated JeM, along with Lashkar e-Tayyiba, in the December 2001 attack on the Indian Parliament that killed nine people and injured 18 others.

In 2002, Pakistani authorities arrested and convicted a JeM member for the abduction and murder of U.S. journalist Daniel Pearl. In December 2003, Pakistan implicated JeM members in two assassination attempts against then-President Pervez Musharraf.

In 2016, Indian officials blamed JeM for a January attack on an Indian Air Force base in Pathankot that killed one civilian and seven Indian security force personnel. In June 2017, Indian police stated that JeM had conducted multiple attacks against security forces across the state of Jammu and Kashmir, injuring more than a dozen people.

In February 2018, JeM claimed responsibility for killing nine Indian officers at the Sunjuwan military station. In December 2018, several JeM militants stormed a police outpost in the Indian state of Jammu and Kashmir killing four police officers and injuring one other. In February 
2019, JeM claimed responsibility for a suicide bombing that killed 40 personnel from India's Central Reserve Police Force in the city of Pulwama in the state of Jammu and Kashmir.

Strength: JeM has several hundred armed supporters.

Location/Area of Operation: India, Afghanistan, and Pakistan

Funding and External Aid: To avoid asset seizures by the Pakistani government, since 2007 JeM has withdrawn funds from bank accounts and invested in legal businesses, such as commodity trading, real estate, and the production of consumer goods. JeM also collects funds through donation requests, sometimes using charitable causes to solicit donations.

\section{JAYSH RIJAL AL-TARIQ AL-NAQSHABANDI}

Aka Army of the Men of the Naqshbandi Order; Armed Men of the Naqshabandi Order; Naqshbandi Army; Naqshabandi Army; Men of the Army of al-Naqshbandia Way; Jaysh Rajal al-Tariqah al-Naqshbandia; JRTN; JRN; AMNO

Description: Jaysh Rijal al-Tariq al-Naqshabandi (JRTN) was designated as an FTO in September 30, 2015. The group first announced insurgency operations against international forces in Iraq in December 2006 in response to the execution of Saddam Hussein. Izzat Ibrahim al-Douri, former vice president of Saddam Hussein's Revolutionary Council, leads the group, which consists of former Baath Party officials, military personnel, and Sunni nationalists. JRTN aims to overthrow the Government of Iraq, install a new Ba'athist regime, and end external influence in Baghdad.

Activities: Between its founding in 2006 and the 2011 withdrawal of Coalition Forces from Iraq, JRTN claimed responsibility for numerous attacks on U.S. bases and forces. JRTN also is known to have used VBIEDs against Iraqi government security forces.

In 2014, elements of JRTN joined military forces with ISIS in opposition to the Iraqi government. JRTN played a major role in the capture of Mosul from Iraqi security forces in 2014. However, fissures between ISIS and JRTN quickly emerged after ISIS's advance in Baiji and Tikrit. Although some elements of JRTN splintered off, the majority of the organization was subsumed by ISIS. JRTN did not claim responsibility for any attacks between 2016 and 2019.

Strength: Precise numbers are unknown.

Location/Area of Operation: Iraq

Funding and External Aid: JRTN has received funding from former regime members, major tribal figures in Iraq, and from Gulf-based financiers of terrorism.

\section{JEMAAH ANSHORUT TAUHID}

Aka JAT; Jemmah Ansharut Tauhid; Jem'mah Ansharut Tauhid; Jamaah Ansharut Tauhid; Jama'ah Ansharut Tauhid; Laskar 99; JAT

Description: Jemaah Anshorut Tauhid (JAT) was designated as an FTO on March 13, 2012. Formed in 2008, the Indonesia-based group seeks to establish an Islamic caliphate in Indonesia and has carried out numerous attacks on Indonesian government personnel, police, military, and civilians. In 2011, Abu Bakar Ba'asyir, the founder and leader of JAT, was sentenced to 15 
years in prison for his role in organizing a militant training camp in Aceh. Ba'asyir is also the co-founder and former leader of Jemaah Islamiya (JI). JAT maintains ties to JI and other terrorist groups in Southeast Asia.

Activities: JAT has conducted multiple attacks targeting civilians and Indonesian officials, resulting in the deaths of numerous Indonesian police and innocent civilians. In December 2012, four police officers were killed and two wounded in an attack by suspected local JAT members in central Sulawesi. Since Abu Bakar Ba'asyir's pledge of allegiance to ISIS in 2014, many JAT members have joined Indonesia's ISIS-affiliated groups, while others have joined al-Qa'idaaffiliated groups. Although JAT did not claim responsibility for any attacks between 2016 and 2019, JAT members are believed to have been involved in ISIS operations in Southeast Asia.

Strength: JAT is estimated to have several thousand supporters and members. Internal disagreements over aligning with ISIS have likely reduced its membership.

\section{Location/Area of Operation: Indonesia}

Funding and External Aid: JAT raises funds through membership donations and legitimate business activities. JAT also has conducted cyber hacking, robbed banks, and carried out other illicit activities to fund the purchase of assault weapons, ammunition, explosives, and bombmaking materials.

\section{JEMAAH ISLAMIYA}

Aka Jemaa Islamiyah; Jema’a Islamiyah; Jemaa Islamiyya; Jema’a Islamiyya; Jemaa

Islamiyyah; Jema'a Islamiyyah; Jemaah Islamiah; Jemaah Islamiyah; Jema’ah Islamiyah; Jemaah Islamiyyah; Jema'ah Islamiyyah; JI

Description: Designated as an FTO on October 23, 2002, Jemaah Islamiya (JI) is a Southeast Asia-based terrorist group co-founded by Abdullah Sungkar and Abu Bakar Ba'asyir. The group seeks to establish an Islamic caliphate in the region. More than $400 \mathrm{JI}$ operatives have been captured or killed since 2002, including operations chief and al-Qa'ida associate Hambali and, in January 2015, bomb-maker Zulfiki bin Hir (aka Marwan).

Activities: Significant JI attacks include the 2002 Bali bombings, which killed more than 200 people, among them seven U.S. citizens; the August 2003 bombing of the J.W. Marriott Hotel in Jakarta; the September 2004 bombing outside the Australian Embassy in Jakarta; and the October 2005 suicide bombing in Bali, which killed 26 people.

In July 2009, a JI faction claimed responsibility for suicide attacks on the J.W. Marriott and RitzCarlton hotels in Jakarta that killed seven people and injured more than 50, including seven U.S. citizens.

In January 2015, 44 policemen and three civilians were killed during a raid targeting two JI members in Mamasapano on the island of Mindanao in the southern Philippines.

In June 2019, Indonesian authorities arrested several JI members, including its emir Para Wijayanto. Indonesian police said that between 2013 and 2018, under Wijayanto's leadership, JI sent at least six groups to Syria for military training or to participate in the fighting.

JI did not claim responsibility for any terrorist attacks between 2016 and 2019. 
Strength: Estimates of JI membership vary from 500 to several thousand members.

Location/Area of Operation: Indonesia, Malaysia, and the Philippines

Funding and External Aid: JI fundraises through membership donations, criminal actions, and business activities. The group has received financial, ideological, and logistical support from Middle Eastern contacts and illegitimate charities and organizations.

\section{JAYSH AL-ADL}

Aka People's Resistance Movement of Iran (PMRI); Jonbesh-i Moqavemat-i-Mardom-i Iran; Popular Resistance Movement of Iran; Soldiers of God; Fedayeen-e-Islam; Former Jundallah of Iran; Jundallah; Jundullah; Jondullah; Jundollah; Jondollah; Jondallah; Army of God (God's Army); Baloch Peoples Resistance Movement (BPRM); Jeysh al-Adl; Army of Justice; Jaish ulAdl; Jaish al-Adl; Jaish Aladl; Jeish al-Adl

Description: Jaysh al-Adl was designated as an FTO on November 4, 2010, under the name Jundallah. Since its inception in 2003, Jaysh al-Adl, has engaged in numerous attacks, killing and maiming scores of Iranian civilians and government officials. The group's stated goals are to secure recognition of Balochi cultural, economic, and political rights from the Government of Iran, and to spread awareness of the plight of the Baloch people. The group adopted the name Jaysh al-Adl in 2012 and has since claimed responsibility for attacks under that name.

Activities: Jaysh al-Adl claimed responsibility for an October 2009 suicide bomb attack in the Sistan va Balochistan province that killed more than 40 people and was reportedly the deadliest terrorist attack in Iran since the 1980s. In a statement on its website, Jaysh al-Adl claimed responsibility for the December 15, 2010, suicide bomb attack inside the Iman Hussein Mosque in Chabahar, which killed an estimated 35 to 40 civilians and wounded 60 to 100. In July 2010, Jaysh al-Adl attacked the Grand Mosque in Zahedan, killing about 30 people and injuring an estimated 300. In June 2018, Jaysh al-Adl, reportedly killed three Iranian security personnel while trying to enter Iran from Pakistan. In October 2018, Jaysh al-Adl claimed responsibility for abducting 12 Iranian security personnel on the border with Pakistan. In February 2019, Jaysh al-Adl claimed responsibility for a suicide car bombing in southeastern Iran that killed 27 Iranian government officials.

Strength: Precise numbers are unknown.

Location/Area of Operation: Iran, Afghanistan, and Pakistan

Funding and External Aid: Sources of support are unknown.

\section{KAHANE CHAI}

Aka American Friends of the United Yeshiva; American Friends of Yeshivat Rav Meir; Committee for the Safety of the Roads; Dikuy Bogdim; DOV; Forefront of the Idea; Friends of the Jewish Idea Yeshiva; Jewish Legion; Judea Police; Judean Congress; Kach; Kahane; Kahane Lives; Kahane Tzadak; Kahane.org; Kahanetzadak.com; Kfar Tapuah Fund; Koach; Meir's Youth; New Kach Movement; Newkach.org; No'ar Meir; Repression of Traitors; State of Judea; Sword of David; The Committee Against Racism and Discrimination (CARD); The Hatikva Jewish Identity Center; The International Kahane Movement; The Jewish Idea Yeshiva; The Judean Legion; The Judean Voice; The Qomemiyut Movement; The Rabbi Meir David Kahane 
Memorial Fund; The Voice of Judea; The Way of the Torah; The Yeshiva of the Jewish Idea; Yeshivat Harav Meir

Description: Kahane Chai (KC) was designated as an FTO on October 8, 1997. Radical IsraeliAmerican Rabbi Meir Kahane founded Kach - the precursor to $\mathrm{KC}$ - with the aim of restoring Greater Israel (Israel, the West Bank, and Gaza). Its offshoot, Kahane Chai (translation: “Kahane Lives"), was founded by Meir Kahane's son Binyamin, following his father's 1990 assassination. In 1994, the group was banned from running in Israeli elections.

Activities: KC has harassed and threatened Arabs, Palestinians, and Israeli government officials and vowed revenge for the December 2000 death of Binyamin Kahane and his wife. The group is suspected of involvement in a number of low-level attacks dating back to the start of the Second Palestinian Intifada in 2000. KC was last linked to an attack in 2005, when one of its members killed four people on a bus in Shfaram, Israel.

Strength: KC's core membership has been estimated to be fewer than 100 .

Location/Area of Operation: Israel and the West Bank

Funding and External Aid: $\mathrm{KC}$ has received support from sympathizers in the United States and Europe.

\section{KATA’IB HIZBALLAH}

Aka Hizballah Brigades; Hizballah Brigades in Iraq; Hizballah Brigades-Iraq; Kata'ib Hezbollah; Khata'ib Hezbollah; Khata'ib Hizballah; Khattab Hezballah; Hizballah Brigades-Iraq of the Islamic Resistance in Iraq; Islamic Resistance in Iraq; Kata'ib Hizballah Fi al-Iraq; Katibat Abu Fathel al-A’abas; Katibat Zayd Ebin Ali; Katibut Karbalah

Description: Formed in 2006 as an anti-Western Shia group, Kata'ib Hizballah (KH) was designated as an FTO on July 2, 2009. Prior to the withdrawal of U.S. troops from Iraq in 2011, the group conducted attacks against U.S., Iraqi, and Coalition targets in Iraq and threatened the lives of Iraqi politicians and civilians supporting the legitimate political process in Iraq. $\mathrm{KH}$ is notable for its extensive use of media operations and propaganda, such as filming and releasing videos of attacks. $\mathrm{KH}$ has ideological ties to and receives support from Iran.

Activities: KH has claimed responsibility for numerous terrorist attacks since 2007, including IED attacks, rocket-propelled grenade attacks, and sniper operations. In 2007, KH gained notoriety for its attacks against U.S. and Coalition Forces in Iraq. In June 2011, five U.S. soldiers were killed in Baghdad when $\mathrm{KH}$ assailants fired multiple rockets at U.S. military base, Camp Victory. The group remained active in 2015, fighting in Syria in support of the Assad regime and in Iraq against ISIS.

In 2016, KH continued to fight ISIS alongside the Iraqi army, but operated outside the Iraqi government's command-and-control structure. In 2017, the group threatened to fight "American occupiers" in Iraq in an article published on the group's official website. In 2018, the group issued a warning statement threatening the U.S. presence in Iraq in retaliation for a non-Coalition airstrike that hit KH members in Syria.

In June 2019, KH members stormed the Bahraini embassy in Baghdad in protest of Bahrain hosting America's Israel-Palestine conference. In October 2019, KH was reportedly involved in 
sniper operations against Iraqi protestors. On December 27, KH was blamed for a rocket attack on K-1 Air Base in Kirkuk that killed one U.S. citizen. On December 31, members of KH broke into the U.S. Embassy compound and participated in a violent attack against the facility, setting fires inside which destroyed security checkpoints and reception rooms.

Strength: Precise numbers are unknown.

Location/Area of Operation: Iraq and Syria

Funding and External Aid: KH depends heavily on support from Iran.

\section{KURDISTAN WORKERS' PARTY}

Aka the Kurdistan Freedom and Democracy Congress; the Freedom and Democracy Congress of Kurdistan; KADEK; Partiya Karkeran Kurdistan; the People's Defense Force; Halu Mesru Savunma Kuvveti; Kurdistan People's Congress; People's Congress of Kurdistan; KONGRAGEL

Description: Founded by Abdullah Ocalan in 1978 as a Marxist-Leninist separatist organization, the Kurdistan Workers' Party (PKK) was designated as an FTO on October 8, 1997. The group, composed primarily of Turkish Kurds, launched a campaign of violence in 1984. The PKK's original goal was to establish an independent Kurdish state in southeastern Turkey.

Activities: In the early 1990s, the PKK moved beyond rural-based insurgent activities to engage in urban terrorism. Anatolia became the scene of significant violence, with some estimates suggesting at least 40,000 casualties. The PKK foreswore violence from 1999 until June 2004, when its hardline militant wing took control and renounced the self-imposed cease-fire. In 2009, the Turkish government and the PKK resumed peace negotiations, but talks broke down after the PKK carried out an attack in July 2011 that killed 13 Turkish soldiers. In 2012, the PKK claimed responsibility for multiple car bombings that killed more than 10 people. Between December 2012 and July 2015, the Turkish government and the PKK resumed peace negotiations, but the negotiations ultimately broke down - owing partly to domestic political pressures and the war in Syria.

Between January and mid-July 2015, the PKK carried out small-scale armed attacks against Turkey's security forces and military bases. In August 2016, the group claimed a VBIED strike against Sirnak police headquarters, which killed 11 people and wounded more than 70 others. In 2017, Turkish officials blamed the PKK for a car bomb and shooting outside of a courthouse that killed two people and a June attack on a military convoy that killed more than 20 soldiers.

In 2018, numerous attacks by the PKK were reported against Turkey's security forces, including an attack claimed by the PKK in November against a Turkish army base, which resulted in dozens of causalities. On September 12, 2018, a roadside bomb struck a bus carrying workers from the Ministry of Agriculture and Forestry, killing seven and wounding 13 in Diyarbakir province's Kulp district. The government blamed the PKK for the attack.

In 2019, the PKK engaged in terrorist attacks in eastern and western Turkey, when the PKK struck over the border from its bases within Iraq. In September, the PKK attacked a Turkish military vehicle in Hakkari province, killing two soldiers and wounding another. In July, the PKK was accused of assassinating a senior Turkish diplomat in Erbil, Iraq. 
Strength: The PKK is estimated to consist of 4,000 to 5,000 members

Location/Area of Operation: Turkey, Iraq, Iran, and Syria

Funding and External Aid: The PKK receives financial support from the large Kurdish diaspora in Europe.

\section{LASHKAR E-TAYYIBA}

Aka al Mansooreen; Al Mansoorian; Army of the Pure; Army of the Pure and Righteous; Army of the Righteous; Lashkar e-Toiba; Lashkar-i-Taiba; Paasban-e-Ahle-Hadis; Paasban-e-Kashmir; Paasban-i-Ahle-Hadith; Pasban-e-Ahle-Hadith; Pasban-e-Kashmir; Jamaat-ud-Dawa; JUD; Jama'at al-Dawa; Jamaat ud-Daawa; Jamaat ul-Dawah; Jamaat-ul-Dawa; Jama'at-i-Dawat; Jamaiat-ud-Dawa; Jama'at-ud-Da'awah; Jama'at-ud-Da'awa; Jamaati-ud-Dawa; Idara Khidmate-Khalq; Falah-i-Insaniat Foundation; FiF; Falah-e-Insaniat Foundation; FalaheInsaniyat; Falah-i-Insaniyat; Falah Insania; Welfare of Humanity; Humanitarian Welfare Foundation; Human Welfare Foundation; Al-Anfal Trust; Tehrik-e-Hurmat-e-Rasool; TehrikeTahafuz Qibla Awwal; Al-Muhammadia Students; Al-Muhammadia Students Pakistan; AMS; Tehreek-e-Azadi-e-Kashmir; Kashmir Freedom Movement; Tehreek Azadi Jammu and Kashmir; Tehreek-e-Azadi Jammu and Kashmir; TAJK; Movement for Freedom of Kashmir; Tehrik-i-Azadi-i Kashmir; Tehreek-e-Azadi-e-Jammu and Kashmir; Milli Muslim League; Milli Muslim League Pakistan; MML

Description: Designated as an FTO on December 26, 2001, Lashkar e-Tayyiba (LeT) is an antiIndia-focused terrorist group. LeT was formed in the late 1980s as the terrorist wing of Markaz ud Dawa ul-Irshad, a Pakistan-based extremist organization and charity originally formed to oppose the Soviet presence in Afghanistan. LeT is led by Hafiz Muhammad Saeed. Shortly after LeT's FTO designation, Saeed changed the group's name to Jamaat-ud-Dawa (JUD) and launched humanitarian projects to circumvent sanctions. LeT disseminates its message through JUD's media outlets. Since the creation of JUD, LeT has repeatedly changed its name in an effort to avoid sanctions.

Elements of LeT and Jaish-e-Muhammed (JeM) have combined with other groups like Hizbul Mujahideen to mount anti-India attacks. The Pakistani government banned LeT in January 2002 and temporarily arrested Hafiz Saeed following the 2008 Mumbai attack. On January 30, 2017, Pakistan placed Saeed under house arrest; however, he was released in November 2017 after a Lahore High Court judicial body rejected a government request to renew his detention. In July 2019, Pakistani police again arrested Saeed and charged him with financing terrorism.

Activities: LeT has conducted operations, including several high profile attacks, against Indian troops and civilian targets since 1993. The group also has attacked Coalition Forces in Afghanistan. LeT uses assault rifles, machine guns, mortars, explosives, and rocket-propelled grenades.

LeT was responsible for the November 2008 attacks in Mumbai against luxury hotels, a Jewish center, a train station, and a popular café that killed 166 people - including six U.S. citizens and injured more than 300 . India has charged 38 people in the case; most are at large, however, and thought to be in Pakistan. 
In March 2010, Pakistani-American businessman David Headley pled guilty in a U.S. court to charges related to his role in the November 2008 LeT attacks in Mumbai and to charges related to a separate plot to bomb the Danish newspaper, Jyllands-Posten. Headley testified in the trials of other LeT supporters in 2011 and 2015.

LeT was behind a July 2015 attack in Gurdaspur, Punjab, which killed seven people. In August 2015, operatives affiliated with LeT attacked Indian security forces in Udhampur, in the Indian state of Jammu and Kashmir. In December 2015, LeT carried out an attack on an Indian paramilitary convoy after it left Srinagar, Kashmir, injuring one civilian and seven Indian military personnel.

From February to May 2016, LeT was suspected of engaging in at least three firefights with Indian security forces in Kupwara district, in the state of Jammu and Kashmir, injuring two Indian personnel. In June 2016, LeT was suspected of conducting an ambush on an Indian security force convoy in Pulwama district, in the state of Jammu and Kashmir, killing eight and injuring 20. Some media reports alleged the group's involvement in the September 2016 attack on an Indian army camp in Uri, in the state of Jammu and Kashmir, which killed 20 soldiers.

In June 2017, LeT conducted an attack in the Indian state of Jammu and Kashmir that left six police officers dead. In July, LeT militants attacked a bus of pilgrims returning from the Amarnath Yatra shrine, killing seven people. In June 2018, LeT claimed responsibility for a suicide attack against an Indian army camp in the state of Jammu and Kashmir's Bandipora district that killed three soldiers. LeT did not claim responsibility for any attacks in 2019.

Strength: Precise numbers are unknown.

Location/Area of Operation: Pakistan, India, and Afghanistan

Funding and External Aid: LeT collects donations in Pakistan and the Gulf as well as from other donors in the Middle East and Europe - particularly the UK, where it is a designated terrorist organization. In 2019, LeT and its front organizations continued to operate and fundraise in Pakistan.

\section{LASHKAR I JHANGVI}

Aka Army of Jhangvi; Lashkar e Jhangvi; Lashkar-i-Jhangvi

Description: Designated as an FTO on January 30, 2003, Lashkar I Jhangvi (LJ) is the terrorist offshoot of the Sunni Deobandi sectarian group Sipah-i-Sahaba Pakistan. LJ carries out antiShia and other sectarian attacks in Afghanistan and Pakistan. The Government of Pakistan banned the group in August 2001 as part of an effort to rein in sectarian violence, causing many LJ members to seek refuge in Afghanistan with the Taliban, with whom the group had existing ties. After the collapse of the Taliban government in Afghanistan, LJ members became active in aiding other terrorists and have provided them with safe houses, false identities, and protection in Pakistani cities. LJ works closely with Tehrik-e Taliban Pakistan. LJ chief Asif Chotu was killed along with three other LJ militants in a police operation in Pakistan in January 2017.

In May 2018, LJ's Balochistan chief, Salman Badini, and two other LJ militants were killed during a police raid in Quetta, Pakistan. 
Activities: LJ specializes in armed attacks and bombings and has admitted to numerous killings of Shia religious and community leaders in Pakistan. In January 1999, the group attempted to assassinate then-Prime Minister Nawaz Sharif and his brother Shahbaz Sharif, Chief Minister of Punjab province. Media reports linked LJ to attacks on Christian targets in Pakistan, including a March 2002 grenade assault on the Protestant International Church in Islamabad that killed two U.S. citizens.

In January 2014, more than 24 people were killed and 40 others wounded in a bus bombing by an LJ attack targeting Shia pilgrims. LJ claimed responsibility for the December 2015 suicide bombing that targeted a market in the predominantly Shia town of Parachinar, Pakistan, that killed at least 23 people and wounded 50. In November 2016, two individuals suspected of belonging to LJ were arrested by police in Pakistan for their alleged involvement in 25 cases of targeted killings, including the murder of Pakistani singer Amjad Sabri, as well as army and police personnel. In April 2019, LJ claimed responsibility for the bombing of a market in Quetta, Pakistan that killed 20 people. The attack reportedly targeted the local minority Shia Muslim Hazara community.

Strength: LJ's membership is assessed to be in the low hundreds.

Location/Area of Operation: Pakistan and Afghanistan

Funding and External Aid: LJ's funding comes from wealthy donors in Pakistan and the Middle East, particularly Gulf States. The group engages in criminal activity, including extortion, to fund its activities.

\section{LIBERATION TIGERS OF TAMIL EELAM}

Aka Ellalan Force; Tamil Tigers

Description: Founded in 1976 and designated as an FTO on October 8, 1997, the Liberation Tigers of Tamil Eelam (LTTE) is a Tamil secessionist group in Sri Lanka. Despite its military defeat at the hands of the Sri Lankan government in 2009, the LTTE's international network of sympathizers and financial support has persisted.

Activities: Although largely inactive since 2009, the LTTE was responsible for an integrated insurgent strategy that targeted key installations and senior Sri Lankan leaders. In early 2009, Sri Lankan forces recaptured the LTTE's key strongholds, including their capital of Kilinochchi. In May 2009, government forces defeated the last LTTE fighting forces, killed members of its leadership including leader Velupillai Prabhakaran, and declared military victory.

There have been no known attacks in Sri Lanka attributed to the LTTE since 2009, but 13 LTTE supporters, several of whom had allegedly planned attacks against U.S. and Israeli diplomatic facilities in India, were arrested in Malaysia in 2014. Additional members were arrested in Malaysia and India in 2015, one of whom was accused of exhorting other Sri Lankans to fund and revive the LTTE.

Strength: Precise numbers are unknown.

Location/Area of Operation: Sri Lanka, India, and Malaysia 
Funding and External Aid: The LTTE's financial network of support continued after the group's military defeat in 2009. The LTTE has employed charities as fronts to collect and divert funds for its activities.

\section{MUJAHIDIN SHURA COUNCIL IN THE ENVIRONS OF JERUSALEM}

Aka MSC; Mujahideen Shura Council in the Environs of Jerusalem; Mujahideen Shura Council; Shura al-Mujahedin Fi Aknaf Bayt al-Maqdis; Majlis Shura al-Mujahidin; Majlis Shura alMujahideen; Magles Shoura al-Mujahddin

Description: The Mujahidin Shura Council in the Environs of Jerusalem (MSC) was designated as an FTO on August 19, 2014. The MSC is a consolidation of several Salafi terrorist groups based in Gaza that have claimed responsibility for numerous attacks against Israel since the group's founding in 2012.

Activities: In August 2013, MSC claimed responsibility for a rocket attack targeting the Israeli city of Eilat. Previously, MSC claimed responsibility for the March 2013, attack in which Gazabased militants fired at least five rockets at Sderot, Israel, and the April 2013 attack in which two rockets were fired at Eilat. MSC did not claim responsibility for any attacks in 2019.

Strength: MSC is estimated to have several hundred fighters.

\section{Location/Area of Operation: Gaza}

Funding and External Aid: Sources of funding are unknown.

\section{AL-MURABITOUN}

Aka al-Mulathamun Battalion; al-Mulathamun Brigade; al-Muwaqqi'un bil-Dima; Those Signed in Blood Battalion; Signatories in Blood; Those who Sign in Blood; Witnesses in Blood; Signedin-Blood Battalion; Masked Men Brigade; Khaled Abu al-Abbas Brigade; al-Mulathamun Masked Ones Brigade; The Sentinels

Description: Al-Murabitoun was designated as an FTO on December 19, 2013, originally under the name al-Mulathamun Battalion. Al-Murabitoun was originally part of al-Qa'ida in the Islamic Maghreb (AQIM), but became a separate organization in late 2012 after its leader, Mokhtar Belmokhtar, split from AQIM. After the split, Belmokhtar threatened to fight against Western interests and announced the creation of the al-Mulathamun Battalion. In 2013, the alMulathamun Battalion and the Mali-based Movement for Unity and Jihad in West Africa (MUJAO) announced that the two organizations would merge under the name "al-Murabitoun." In 2015, al-Murabitoun announced a re-merger with AQIM. In 2017, the Sahara Branch of alQa'ida in the Islamic Maghreb, al-Murabitoun, Ansar al-Dine, and the Macina Liberation Front came together to form Jama'at Nusrat al-Islam wal-Muslimin (JNIM).

Activities: In January 2013, what is now known as al-Murabitoun claimed responsibility for the attack against the Tiguentourine gas facility near In Amenas, in southeastern Algeria. More than 800 people were taken hostage during the four-day siege, resulting in the deaths of 39 civilians, including three U.S. citizens. Seven other U.S. citizens escaped.

In May 2013, al-Murabitoun participated in twin suicide bombings on a northern Nigerien military base and a French uranium mine in Arlit. The coordinated attacks killed more than 20 people, including all of the attackers. 
In March 2015, al-Murabitoun claimed responsibility for an attack at La Terrasse restaurant in Bamako, Mali that killed a French national, a Belgian national, and three Malians. AlMurabitoun also claimed responsibility for the August 2015 hotel siege in central Mali that killed 17 people. In November 2015, al-Murabitoun operatives participated in the strike against the Radisson Blu Hotel in Bamako, Mali, taking more than 170 people hostage - including U.S. citizens. Nearly 27 people were killed in the attack, among them a U.S. international development worker.

Al-Murabitoun was reportedly involved in the AQIM January 2016 attack on a popular tourist hotel in Burkina Faso that killed nearly 30, including a U.S. citizen. In addition, al-Murabitoun claimed responsibility for a January 2017 suicide car bombing at a military camp in Mali that killed more than 47 people and injured more than 115. In July 2018, al-Murabitoun was involved in fighting against French forces in Mali. Al-Murabitoun remained active in 2019.

Strength: Precise numbers are unknown.

Location/Area of Operation: Algeria, Burkina Faso, Libya, Mali, and Niger

Funding and External Aid: In addition to the support it may receive through its connections to other terrorist organizations in the region, al-Murabitoun is likely funded through kidnappingfor-ransom and other criminal activities.

\section{NATIONAL LIBERATION ARMY}

Aka ELN; Ejército de Liberación Nacional.

Description: The National Liberation Army (ELN) was designated as an FTO on October 8, 1997. The ELN is a Colombian Marxist-Leninist group formed in 1964. The ELN remains focused on attacking the security services and economic infrastructure - in particular oil and gas pipelines and electricity pylons - and on extorting foreign and local companies and commits crimes and acts of terror throughout the country, including violence against civilian populations in Colombia and Venezuela

Activities: The ELN continued to target Colombia's infrastructure, particularly oil pipelines. The ELN also launched mortars at police stations and the military; placed explosive devices near roads; and engaged in sniper attacks, roadblocks, and ambushes. Additionally, the ELN continued to kidnap civilians and members of the security services.

Throughout 2017, the Government of Colombia and the ELN conducted peace talks but did not ultimately reach an agreement. Peace talks were intermittent throughout 2018 after being suspended in January following a series of ELN bombings that killed several police officers and injured dozens more. The government ended talks following a January 2019 vehicle-borne improvised explosive device attack by the ELN on the General Santander National Police Academy. The attack was the deadliest Bogotá had experienced in years, killing 22 police cadets and injuring 87 more. Colombian officials also attributed a number of oil pipeline bombings to the ELN in 2019.

Strength: ELN consists of about 3,000 armed combatants.

Location/Area of Operation: Colombia and Venezuela 
Funding and External Aid: The ELN draws its funding from the illicit narcotics trade, extortion of oil and gas companies and landowners, and illegal mining in Colombia and Venezuela. Additional funds are derived from kidnapping-for-ransom payments.

\section{AL-NUSRAH FRONT}

Aka Jabhat al-Nusrah; Jabhet al-Nusrah; The Victory Front; al-Nusrah Front for the People of the Levant; al-Nusrah Front in Lebanon; Jabhat al-Nusra li-Ahl al-Sham min Mujahedi al-Sham fi Sahat al-Jihad; Support Front for the People of the Levant; Jabhat Fath al-Sham; Jabhat Fath al Sham; Jabhat Fatah al-Sham; Jabhat Fateh al-Sham; Front for the Conquest of Syria; the Front for liberation of al Sham; Front for the Conquest of Syria/the Levant; Front for the Liberation of the Levant; Conquest of the Levant Front; Fatah al-Sham Front; Fateh al-Sham Front; Hay'at Tahrir al-Sham; Hay'et Tahrir al-Sham; Hayat Tahrir al-Sham; HTS; Assembly for the Liberation of Syria; Assembly for Liberation of the Levant; Liberation of al-Sham Commission; Liberation of the Levant Organization; Tahrir al-Sham; Tahrir al-Sham Hay'at

Description: Al-Nusrah Front (ANF) was designated as an FTO on May 15, 2014, and is alQa'ida's affiliate in Syria. It is led by Abu Muhammad al-Jawlani. The group was formed in late 2011 when then-al-Qa'ida in Iraq (AQI) - now ISIS - leader Abu Bakr al-Baghdadi sent alJawlani to Syria to organize terrorist cells. In 2013, the group split from AQI and became an independent entity. ANF's stated goal is to oust Syria's Assad regime and replace it with a Sunni Islamic state. The group is concentrated in and controls a portion of territory in northwest Syria, where it is active as an opposition force, and exerts varying degrees of influence over local governance and external plotting.

In early 2017, ANF joined with four smaller Syrian factions and created Hay'at Tahrir al-Sham (HTS) as a vehicle to advance its position in the Syrian insurgency and further its own goals as al-Qa'ida's affiliate in Syria.

Activities: ANF has been active in operations against other factions in the Syrian conflict. In 2016, the group carried out attacks in Aleppo and other parts of Syria controlled by the Syrian army, killing both military officials and civilians.

Since 2017, ANF has continued to operate through HTS in pursuit of its objectives. In October 2017, ANF launched an attack near the Turkish border against the Syrian army, killing several soldiers. In March, the group carried out multiple suicide bombings in Damascus, including suicide attacks using VBIEDs. ANF took control of significant portions of Idlib from 2017 to 2019, exerting severe military pressure over other local groups such as Ahrar ash-Sham and Nur ad-Din al-Zinki as it fought against the regime and continued plotting against U.S. and allied interests.

In 2019, the group suffered heavy casualties, estimated in the hundreds, from engagement with Russian-backed Syrian government forces.

Strength: ANF has between 5,000 and 10,000 fighters.

\section{Location/Area of Operation: Syria}

Funding and External Aid: ANF receives funding from a variety of sources, including kidnapping-for-ransom payments, taxes and fees on border crossings it controls, and donations 
from external Gulf-based donors. The group also generates revenue by collecting fees from commercial traffic entering and exiting Idlib.

\title{
PALESTINE ISLAMIC JIHAD
}

Aka PIJ; PIJ-Shaqaqi Faction; PIJ-Shallah Faction; Islamic Jihad of Palestine; Islamic Jihad in Palestine; Abu Ghunaym Squad of the Hizballah Bayt al-Maqdis; Al-Quds Squads; Al-Quds Brigades; Saraya al-Quds; Al-Awdah Brigades

Description: Palestine Islamic Jihad (PIJ) was designated as an FTO on October 8, 1997. Formed by militant Palestinians in Gaza during the 1970s, PIJ is committed to the destruction of Israel and to the creation of an Islamic state in historic Palestine, including present-day Israel.

Activities: PIJ terrorists have conducted numerous attacks, including large-scale suicide bombings, against Israeli civilian and military targets. Between 2008 and 2011, PIJ conducted rocket attacks and used other explosive devices to target southern Israel. Throughout 2014, PIJ operatives carried out attacks on Israeli buses in Tel Aviv. In March 2014, PIJ carried out a wave of rocket attacks into Israeli territory; up to 60 rockets may have reached Israel.

In 2015, PIJ revealed that its militants were smuggling weapons, including Gaza-made rockets and mortars, through tunnels in Gaza, in preparation for future attacks against Israel. In May 2015, Israeli forces blamed PIJ for firing a rocket that landed in Gan Yazne, a region close to the Gaza border. In August 2015, the Israel Defense Forces (IDF) claimed PIJ operatives in Syria fired four rockets at the Golan Heights and Upper Galilee.

Throughout 2016, PIJ continued to strike Israel, primarily through light arms fire directed at IDF patrols. In September 2016, Israeli authorities arrested PIJ operative Mahmoud Yusuf Hasin Abu Taha upon his entry into Israel from Gaza, interrupting a PIJ plot to abduct and kill an IDF soldier and carry out a mass-casualty attack on a reception hall in Beersheba. In 2017, PIJ praised numerous shootings, bombings, and other attacks in Israel that resulted in multiple deaths. PIJ claimed responsibility for launching rockets into Israel throughout 2018 and 2019. In a November 2019 video, PIJ's Al-Quds Brigade introduced a new rocket to its arsenal and thanked Iran for its support.

Strength: PIJ has close to 1,000 members.

Location/Area of Operation: Israel, Gaza, and the West Bank

Funding and External Aid: PIJ receives financial assistance and training primarily from Iran. PIJ has partnered with Iran- and Syria-sponsored Hizballah to carry out joint operations.

\section{PALESTINE LIBERATION FRONT - ABU ABBAS FACTION}

\author{
Aka PLF; PLF-Abu Abbas; Palestine Liberation Front
}

Description: The Palestinian Liberation Front-Abu Abbas Faction (PLF) was designated as an FTO on October 8, 1997. In the late 1970s, the PLF splintered from the Popular Front for the Liberation of Palestine-General Command. It later split into pro-Palestinian Liberation Organization (PLO), pro-Syrian, and pro-Libyan factions. The pro-PLO faction was led by Muhammad Zaydan (aka Abu Abbas) and was based in Baghdad before Operation Iraqi Freedom. 
Activities: The PLF was responsible for the 1985 attack on the Italian cruise ship Achille Lauro and the murder of U.S. citizen Leon Klinghoffer. Throughout the 1990s, the PLF was suspected of supporting terrorism against Israel by other Palestinian groups. In April 2004, Abu Abbas died of natural causes while in U.S. custody in Iraq. After not claiming an attack for 16 years, the PLF claimed responsibility for the March 2008 assault against an Israeli military bus in Huwarah, Israel, and the shooting of an Israeli settler. In February 2010, the PLF claimed responsibility for an IED attack against an IDF patrol, which caused minor injuries to a soldier; another IED was discovered during a search of the area. The PLF has not claimed responsibility for any attacks since 2016, but continues to maintain a strong presence in many refugee camps in Gaza, Lebanon, and Syria.

Strength: Precise numbers are unknown.

Location/Area of Operation: Gaza, Lebanon, and the West Bank

Funding and External Aid: Sources of funding are unknown.

\section{POPULAR FRONT FOR THE LIBERATION OF PALESTINE}

Aka PFLP; Halhul Gang; Halhul Squad; Palestinian Popular Resistance Forces; PPRF; Red Eagle Gang; Red Eagle Group; Red Eagles; Martyr Abu-Ali Mustafa Battalion

Description: Designated as an FTO on October 8, 1997, the Popular Front for the Liberation of Palestine (PFLP) is a Marxist-Leninist group founded in 1967 by George Habash after splitting from the Arab Nationalist Movement. The group earned a reputation for committing large-scale international attacks in the 1960s and 1970s, including airline hijackings that killed more than 20 U.S. citizens.

Activities: The PFLP increased its operational activity during the Second Intifada. During that time, the group assassinated Israeli Tourism Minister Rehavam Ze'evi in 2001, carried out at least two suicide operations, and launched multiple joint operations with other Palestinian terrorist groups. Between 2008 and 2011, the PLFP claimed responsibility for numerous attacks on IDF in Gaza as well as mortar and rocket attacks fired from Gaza into Israel. In 2012, the Israeli Security Agency arrested several members of the PFLP for plotting to carry out attacks on IDF checkpoints and planning to conduct kidnappings.

In November 2014, two Palestinians reportedly affiliated with the PFLP entered a Jerusalem synagogue and attacked Israelis with guns, knives, and axes, killing five people - including three U.S. citizens - and injuring 12. In December, the PFLP claimed responsibility for several rocket attacks along the Lebanese-Israel border.

In June 2017, three Palestinian militants launched an attack near Jerusalem's Old City, stabbing and killing an Israeli border security agent. Two of the militants were PFLP members, although ISIS claimed responsibility for the attack.

In September 2019, IDF and Israeli Border Patrol forces arrested four PFLP members allegedly responsible for remotely detonating an IED in the West Bank, killing an Israeli teenager and seriously wounding two others.

Strength: Precise numbers are unknown.

Location/Area of Operation: Gaza, Israel, Lebanon, Syria, and the West Bank 
Funding and External Aid: Sources of support are unknown.

\title{
POPULAR FRONT FOR THE LIBERATION OF PALESTINE-GENERAL COMMAND
}

\author{
Aka PFLP-GC \\ Description: The Popular Front for the Liberation of Palestine-General Command (PFLP-GC) \\ was designated as an FTO on October 8, 1997. The PFLP-GC split from the Popular Front for \\ the Liberation of Palestine in 1968, claiming it wanted to concentrate more on resistance and less \\ on politics. Ahmad Jibril, a former captain in the Syrian army, has led the PFLP-GC since its \\ founding. The PFLP-GC has close ties to both Syria and Iran.
}

Activities: The PFLP-GC carried out dozens of attacks in Europe and the Middle East during the 1970s and 1980s. The organization was known for conducting cross-border attacks into Israel using unusual means, such as hot-air balloons and motorized hang gliders. Since the early 1990s, the group has primarily focused on supporting Hizballah's attacks against Israel, training members of other Palestinian terrorist groups, and smuggling weapons. More recently, the PFLP-GC has been implicated by Lebanese security officials in several rocket attacks against Israel. In 2009, the group was responsible for wounding two civilians in an armed attack in Nahariyya, Israel.

In November 2012, the PFLP-GC claimed responsibility for a bus bombing in Tel Aviv that injured 29 people, although four Palestine Islamic Jihad and Hamas operatives later were arrested for the attack. In 2015, the PFLP-GC reportedly began fighting alongside the Assad regime in Syria, while also receiving logistical and military aid from Hizballah and Iran.

Separately, in December 2015, the PFLP-GC took responsibility for rocket fire aimed at Israeli territory. The attack, in which at least three rockets were fired from Lebanon into northern Israel, landed near Shlomi, a small town near the Lebanese frontier with Israel. Although the PFLP-GC did not claim responsibility for any attacks in 2019, the group remained an active participant in the Syrian conflict.

Strength: The PFLP-GC has several hundred members.

Location/Area of Operation: Syria, Lebanon, and Gaza

Funding and External Aid: The PFLP-GC receives safe haven and logistical and military support from Syria as well as financial support from Iran.

\begin{abstract}
AL-QA'IDA
Aka al-Qa'eda; al Qaida, al Qaeda, Islamic Army; Islamic Salvation Foundation; The Base; The Group for the Preservation of the Holy Sites; The Islamic Army for the Liberation of the Holy Places; the World Islamic Front for Jihad Against Jews and Crusaders; Usama Bin Laden Network; Usama Bin Laden Organization; al-Jihad; the Jihad Group; Egyptian al-Jihad; Egyptian Islamic Jihad; New Jihad; International Front for Fighting Jews and Crusades; Islamic Army for the Liberation of Holy Sites

Description: Al-Qa'ida (AQ) was designated as an FTO on October 8, 1999. Established in 1988, the group helped finance, recruit, transport, and train fighters for the Afghan resistance against the former Soviet Union. AQ strives to eliminate Western influence from the Muslim world, topple "apostate" governments of Muslim countries, and establish a pan-Islamic caliphate
\end{abstract}


governed by its own interpretation of Sharia law that would ultimately be at the center of a new international order. These goals remain essentially unchanged since the group's 1996 public declaration of war against the United States. AQ leaders issued a statement in 1998 under the banner of "The World Islamic Front for Jihad against Jews and Crusaders," saying it was the duty of all Muslims to kill U.S. citizens - civilian and military - and their allies everywhere. AQ merged with al-Jihad (Egyptian Islamic Jihad) in June 2001. While numerous AQ leaders have been killed in recent years, including Usama bin Laden in 2011, AQ's current leader, Ayman alZawahiri, remains at large.

Activities: AQ conducted three bombings targeting U.S. troops in Aden, Yemen, in 1992 and claimed responsibility for shooting down U.S. helicopters and killing U.S. soldiers in Somalia in 1993. AQ also carried out the 1998 bombings of the U.S. Embassies in Nairobi, Kenya, and Dar es Salaam, Tanzania, killing up to 300 people and injuring more than 5,000. In 2000, AQ conducted a suicide attack on the USS Cole in the port of Aden with an explosive-laden boat, killing 17 U.S. Navy sailors and injuring 39 others.

On September 11, 2001, 19 AQ members hijacked and crashed four U.S. commercial jets - two into the World Trade Center in New York City, one into the Pentagon, and the last into a field in Shanksville, Pennsylvania. Nearly 3,000 civilians, police, and first responders were killed. The dead included U.S. and foreign citizens from at least 77 countries.

In a 2011 video, al-Zawahiri claimed AQ was behind the kidnapping of U.S. aid worker Warren Weinstein in Pakistan. Weinstein was held captive until his death in 2015.

In 2015, five senior AQ leaders were released from Iranian custody in exchange for an Iranian diplomat kidnapped in Yemen. Of the five, Saif al Adel and Abu Mohammed al Masri are wanted for the 1998 U.S. Embassy bombings in Kenya and Tanzania.

In 2016, al-Zawahiri publicly released two audio messages and one seven-page statement, condemning the Government of Saudi Arabia and its role in the Syrian conflict, encouraging AQ activity in Southeast Asia - especially Indonesia, Malaysia, and the Philippines - and acknowledging support for its affiliate in Syria, al-Nusrah Front.

In September 2017, a U.S. citizen was convicted in New York of charges related to supporting AQ to attack a U.S. military base in Afghanistan using two truck bombs in 2009. In October 2017, al-Zawahiri released a video calling for jihadists around the world to conduct attacks against the United States. Al-Zawahiri released multiple recordings and videos in 2018 in which he continued to call for jihad against the United States after the U.S. Embassy in Israel moved from Tel Aviv to Jerusalem.

In July 2019, a man from Cleveland, Ohio, was arrested for allegedly making plans for an AQinspired bomb attack on the city's downtown July 4th parade. In July 2019, Zawahiri called for extremists in Kashmir to attack Indian forces. On September 11, 2019, al-Zawahiri appealed to Muslims to attack U.S., European, Israeli, and Russian military targets in a video recording.

Strength: In South Asia, AQ's core has been seriously degraded. The death or arrest of dozens of mid- and senior-level AQ operatives, including Usama bin Laden, has disrupted communication, financial support, facilitation nodes, and several terrorist plots. AQ, however, remains a focal point of "inspiration" for a worldwide network of affiliated groups. Among them, al-Qa'ida in the Arabian Peninsula (AQAP), al-Qa'ida in the Islamic Maghreb (AQIM), al- 
Nusrah Front, al-Shabaab, al-Qa'ida in the Indian Subcontinent (AQIS), and other terrorist groups, including the Islamic Movement of Uzbekistan, Islamic Jihad Union, Lashkar i Jhangvi, Harakat ul-Mujahideen, and Jemaah Islamiya. The Tehrik-e Taliban Pakistan and the Haqqani Network also have ties to AQ. In addition, supporters and associates worldwide who are "inspired" by the group's ideology may operate without direction from AQ central leadership.

Location/Area of Operation: Afghanistan, Pakistan, Syria, Lebanon, Yemen, North Africa, and Somalia

Funding and External Aid: AQ primarily depends on donations from likeminded supporters, and from individuals who believe that their money is supporting a humanitarian cause. Some funds are diverted from Islamic charitable organizations.

\section{AL-QA'IDA IN THE ARABIAN PENINSULA}

Aka al-Qa'ida in the South Arabian Peninsula; al-Qa'ida in Yemen; al-Qa'ida of Jihad Organization in the Arabian Peninsula; al-Qa'ida Organization in the Arabian Peninsula; Tanzim Qa'idat al-Jihad fi Jazirat al-Arab; AQAP; AQY; Ansar al-Shari'a; Ansar al-Sharia; Ansar alShariah, Ansar al Shariah, Partisans of Islamic Law, Sons of Abyan; Sons of Hadramawt; Sons of Hadramawt Committee; Civil Council of Hadramawt; and National Hadramawt Council

Description: Al-Qa'ida in the Arabian Peninsula (AQAP) was designated as an FTO on January 19, 2010. In January 2009, the now-deceased leader of al-Qa'ida in Yemen, Nasir al-Wahishi, publicly announced that Yemeni and Saudi al-Qa'ida (AQ) operatives were working together under the banner of AQAP. The announcement signaled the rebirth of an AQ franchise that previously carried out attacks in Saudi Arabia. AQAP's stated goals include establishing a caliphate and implementing Sharia law in the Arabian Peninsula and the wider Middle East.

Activities: AQAP has claimed responsibility for numerous terrorist acts against both local and foreign targets since its inception in January 2009. These include a March 2009 suicide bombing against South Korean tourists in Yemen and the December 25, 2009, attempted attack on Northwest Airlines Flight 253 from Amsterdam to Detroit, Michigan. In October 2010, AQAP claimed responsibility for a foiled plot to send explosive-laden packages to the United States via cargo planes. The parcels were intercepted in the UK and the United Arab Emirates.

AQAP, operating under the alias Ansar al-Shari'a, carried out a May 2012 suicide bombing in Sana'a that killed 96 people. The same month, the media reported that AQAP allegedly planned to detonate a bomb aboard a U.S.-bound airliner using an IED.

In January 2015, brothers Cherif and Said Kouachi attacked the satirical newspaper Charlie Hebdo in Paris, France, killing 12 people. One of the brothers, who had traveled to Yemen in 2011 and met with now-deceased Anwar al-Aulaqi, claimed responsibility for the attack on behalf of AQAP.

Also in 2015, AQAP took advantage of Yemen's deteriorating political and economic environment following the Houthi take over - and exile of the Government of Yemen - of the capitol, Sana'a. In April 2015, AQAP stormed the city of Mukalla, seizing control of government buildings, releasing terrorists from prison, and stealing millions from the central bank. Between 2015 and 2016, AQAP consolidated its control over Mukalla and expanded its reach throughout large portions of Yemen's south. 
In early 2016, AQAP swept through southern Yemen, gaining control of al-Hawta, Azzan, and Habban in Lahij Governorate as well as Mahfad and Ahwar in Abyan Governorate. By February 2016, AQAP controlled most of Yemen's southeastern coast. The group lost control of Mukalla in April 2016, when forces backed by the Saudi-led Coalition retook the port city; however, these territorial losses did not significantly degrade AQAP's capabilities, although they did deprive the group of an important source of income.

In early 2017, a U.S. Navy SEAL was killed in a raid against AQAP leaders in Yemen. In June 2017, AQAP attacked a Yemeni army camp, killing at least two soldiers. In 2018, AQAP senior leader, Khaled Batarfi, called on the group's supporters to "rise and attack" Americans "everywhere." In August 2019, AQAP gunmen killed 19 soldiers in an attack on an army base in southern Yemen.

Strength: AQAP fighters are estimated to be in the low thousands.

Location/Area of Operation: Yemen

Funding and External Aid: AQAP's funding has historically come from theft, robberies, oil and gas revenue, kidnap-for-ransom operations, and donations from likeminded supporters.

\section{AL-QA'IDA IN THE INDIAN SUBCONTINENT}

Aka al-Qaeda in the Indian Subcontinent; Qaedat al-Jihad in the Indian Subcontinent

Description: Al-Qa'ida in the Indian Subcontinent (AQIS) was designated as an FTO on July 1, 2016. Established in 2014, AQIS focuses on terrorist activity in Afghanistan, Bangladesh, India, and Pakistan. Its leader is Asim Umar, a former member of the FTO Harakat ul-Mujahideen. In September 2019, the Afghan government reported that Umar was killed in a military raid on a Taliban compound in Helmand Province, Afghanistan.

Activities: In September 2014, AQIS claimed responsibility for an attack on a naval dockyard in Karachi, Pakistan, in which militants attempted to hijack a Pakistani Navy frigate to attack nearby U.S. warships. AQIS also claimed attacks against human rights activists and secular writers in Bangladesh, including U.S. citizen Avijit Roy, U.S. Embassy local employee Xulhaz Mannan, and Bangladeshi nationals Oyasiqur Rahman Babu, Ahmed Rajib Haideer, and A.K.M. Shafiul Islam. In September 2017, AQAP called on AQIS to launch more attacks on Burmese authorities because of Burma's policies towards Rohingya Muslims. AQIS has not claimed responsibility for any attacks since 2017. In 2019, Asim Umar, the head of AQIS, was killed in a joint U.S.-Afghan military operation.

Strength: AQIS is estimated to have several hundred members.

Location/Area of Operations: Afghanistan, Bangladesh, India, and Pakistan

Funding and External Aid: AQIS likely receives funding from al-Qa'ida senior leadership and engages in general criminal activity, kidnapping, and extortion.

\section{AL-QA'IDA IN THE ISLAMIC MAGHREB}

Aka AQIM; GSPC; Le Groupe Salafiste Pour la Predication et le Combat; Salafist Group for Preaching and Combat; Salafist Group for Call and Combat; Tanzim al-Qa'ida fi Bilad alMaghrib al-Islamiya 
Description: The Salafist Group for Call and Combat (GSPC) was designated as an FTO on March 27, 2002. The Department of State amended the GSPC designation on February 20, 2008, after the GSPC officially joined with al-Qa'ida (AQ) in September 2006 and became alQa'ida in the Islamic Maghreb (AQIM). Although AQIM remains largely a regionally focused terrorist group, it has adopted a more anti-Western rhetoric and ideology. The group aspires to overthrow "apostate" African regimes and create an Islamic state. AQIM is led by Abdelmalek Droukdel, also known as Abu Mus'ab Abd al-Wadoud.

Activities: Following AQIM's 2007 bombing of the UN headquarters building and an Algerian government building in Algiers, which killed 60 people, AQIM's northern leadership was contained to northeastern Algeria, while the group's southern battalions focused mostly on kidnapping-for-ransom efforts. In 2011 and 2012, however, AQIM took advantage of the deteriorating security situation across Libya, Mali, and Tunisia to expand its operations. Terrorists with ties to AQIM were involved in the September 11, 2012, attack on U.S. facilities in Benghazi that killed U.S. Ambassador to Libya J. Christopher Stevens and three other embassy staff members. In April 2014, AQIM killed 14 Algerian soldiers in an ambush east of Algiers.

In January 2015, AQIM claimed responsibility for an attack on a UN vehicle in Kidal, Mali, which wounded seven peacekeepers. That same year, AQIM twice attacked UN convoys near Timbuktu, Mali, with small arms and rocket-propelled grenades; three peacekeepers were killed in a May 2015 attack and another six were killed in a July attack. In November 2015, AQIM, in cooperation with other terrorist groups, attacked the Radisson Blu Hotel in Bamako, Mali, taking more than 170 hostages, including U.S. citizens. As many as 27 people were killed in the attack, among them a U.S. international development worker.

In January 2016, AQIM carried out an attack on a hotel in Burkina Faso that killed 28 people and injured 56. In March 2016, AQIM claimed responsibility for a strike on a popular tourist beach resort in Cote d'Ivoire that killed more than 16 people and wounded another 33.

AQIM has continued to conduct kidnapping-for-ransom operations, typically targeting Western citizens from governments or third parties that have an established pattern of paying ransom for the release of individuals. In November 2014, AQIM released a video of two Western hostages (a Dutch national and a French national), who were later released in December 2014.

In January 2017, AQIM conducted a suicide attack that left more than 50 people dead in Gao, Mali. In July 2018, AQIM claimed responsibility for a vehicle suicide attack on an army patrol in Gao that killed four civilians and wounded 31 others, including four French soldiers.

In January 2019, AQIM claimed responsibility for an attack on a UN camp in northern Mali, killing 10 peacekeepers and wounding 25 others.

Strength: AQIM has an estimated 1,000 fighters operating in the Sahel, including Algeria, northern Mali, southwest Libya, and Niger.

Location/Area of Operation: Algeria, Burkina Faso, Cote d'Ivoire, Libya, Mali, Niger, and Tunisia 
Funding and External Aid: AQIM members engage in kidnapping-for-ransom and other criminal activities to finance their operations. AQIM also successfully fundraises globally and receives limited financial and logistical assistance from supporters residing in Western Europe.

\section{REAL IRA}

Aka RIRA; Real Irish Republican Army; 32 County Sovereignty Committee; 32 County Sovereignty Movement; Irish Republican Prisoners Welfare Association; Real Oglaigh Na Heireann

Description: The Real Irish Republican Army (RIRA) was designated as an FTO on May 16, 2001. The group was formed in 1997 as the clandestine armed wing of the 32 County Sovereignty Movement, a "political pressure group" dedicated to removing British forces from Northern Ireland and unifying Ireland. The RIRA has historically sought to disrupt the Northern Ireland peace process and did not participate in the September 2005 weapons decommissioning. Despite internal rifts and calls by some jailed members (including the group's founder Michael "Mickey" McKevitt) for a cease-fire and disbandment, the RIRA has pledged additional violence and continued to conduct attacks. Many RIRA members are former Provisional Irish Republican Army members who left the organization after the group renewed its cease-fire in 1997. These members brought extensive experience in terrorist tactics and bomb-making to the group.

Activities: Targets have included civilians (the most notorious example is the Omagh bombing in August 1998), British security forces, and police officers in Northern Ireland. The Independent Monitoring Commission, which oversees the peace process, assessed that RIRA likely was responsible for the majority of the attacks that occurred after the Irish Republican Army (IRA) was decommissioned in Northern Ireland.

In May 2015, Irish police carried out 20 searches aimed at known dissident republicans across Ireland. Six individuals with links to the RIRA and the Continuity Irish Republican Army (CIRA) were arrested after police discovered explosive devices. In 2016, the RIRA bombed the van of an Irish prison officer in east Belfast; the officer died from complications following the attack. Dublin police also linked the RIRA to a cache of explosives found in Dublin in April 2016. In January 2017, RIRA gunmen fired at police officers in north Belfast, injuring one officer. RIRA did not claim responsibility for any attacks in 2018 and 2019.

Strength: The Irish government reports that the RIRA has roughly 100 active members. The organization may receive limited support from IRA hardliners and sympathizers who are dissatisfied with the IRA's cease-fire and with Sinn Fein's involvement in the peace process.

Location/Area of Operation: Northern Ireland and the Republic of Ireland

Funding and External Aid: RIRA is suspected of receiving funds from sympathizers in the United States and of attempting to buy weapons from U.S. gun dealers. The group reportedly purchased sophisticated weapons from the Balkans and occasionally collaborated with the CIRA.

\section{REVOLUTIONARY ARMED FORCES OF COLOMBIA}

Aka FARC; Fuerzas Armadas Revolucionarias de Colombia

Description: Founded in 1964 and designated as an FTO on October 8, 1997, the Revolutionary Armed Forces of Colombia (FARC) was Latin America's oldest, largest, and best-equipped 
terrorist organization. The FARC was responsible for large numbers of kidnappings-for-ransom in Colombia and held as many as 700 hostages. In November 2016, after four years of negotiation in Havana, Cuba, the Colombian government and FARC reached a peace agreement, later approved by Colombia's Congress, setting into motion a disarmament, demobilization, and reincorporation process. In accordance with the peace agreement, the vast majority of FARC combatants disarmed and demobilized between December 2016 and August 2017 under UN supervision, with roughly 7,000 FARC members turning in more than 8,000 weapons. In 2019, roughly 13,000 FARC ex-combatants and former militia members continued to participate in social and economic reincorporation activities under the 2016 accord. Up to 1,500 FARC guerrillas chose not to participate in the peace process and around 250 have since abandoned the process. FARC dissidents have recruited an estimated 1,000 new members, largely minors, since the signing of the peace accord. Altogether, these individuals are often referred to by the United States as FARC dissidents and as the residual organized armed group by the Colombian government.

Activities: Over the years, the FARC has perpetrated many high-profile terrorist acts, including the 1999 murder of three U.S. missionaries working in Colombia as well as multiple kidnappings and assassinations of Colombian government officials and civilians. In July 2008, the Colombian military conducted a dramatic rescue of 15 high-value FARC hostages, including U.S. Department of Defense contractors Marc Gonsalves, Keith Stansell, and Thomas Howe, who were held captive for more than five years, along with former Colombian presidential candidate Ingrid Betancourt.

There have been reports of continued extortion and violent criminal activities by FARC dissidents not participating in the peace process. In August, former FARC commanders Iván Márquez and Jesus Santrich appeared in a video calling for a return to arms against the Colombian government.

Strength: Before the peace accord, the FARC was estimated to have 7,000 armed members, with several thousand additional supporters.

Location/Area of Operation: Colombia and Venezuela

Funding and External Aid: Before the peace accord, the FARC was primarily funded by extortion and international drug trade. FARC dissidents continue such activities.

\title{
REVOLUTIONARY PEOPLE'S LIBERATION PARTY/FRONT
}

\author{
Aka DHKP/C; Dev Sol; Dev Sol Armed Revolutionary Units; Dev Sol Silahli Devrimci \\ Birlikleri; Dev Sol SDB; Devrimci Halk Kurtulus Partisi-Cephesi; Devrimci Sol; Revolutionary \\ Left
}

Description: Designated as an FTO on October 8, 1997, the Revolutionary People's Liberation Party/Front (DHKP/C) was formed in 1978 as Devrimci Sol, or Dev Sol, a splinter faction of Dev Genc (Revolutionary Youth). It was renamed in 1994 after factional infighting. "Party" refers to the group's political activities and "Front" alludes to the group's militant operations. The group advocates a Marxist-Leninist ideology and opposes the United States, NATO, and the Turkish establishment. It strives to establish a socialist state and to abolish Turkish prisons. 
Activities: Since the late 1980s, the group has primarily targeted current and retired Turkish security and military officials. In 1990, the group began conducting attacks against foreign interests, including U.S. military and diplomatic personnel and facilities. The DHKP/C assassinated two U.S. military contractors, wounded a U.S. Air Force officer, and bombed more than 20 U.S. and NATO military, diplomatic, commercial, and cultural facilities. In 2001, the $\mathrm{DHKP} / \mathrm{C}$ began conducting its first suicide bombing attacks against Turkish police. Since the end of 2001, DHKP/C has typically used IEDs against official Turkish and U.S. targets.

The DHKP/C was responsible for many high-profile attacks in 2012, including the suicide bombing of a police station in Istanbul. In February 2013, a DHKP/C operative exploded a suicide vest inside the employee entrance to the U.S. Embassy in Ankara. The explosion killed a Turkish guard and seriously wounded a Turkish journalist. In March 2013, three members of the group attacked the Ministry of Justice and the Ankara headquarters of the Turkish Justice and Development political party using grenades and rocket launchers.

In 2015, the DHKP/C claimed responsibility for a suicide bombing that killed one police officer and wounded another. In March 2015, Turkish prosecutor Mehmet Selim Kiraz was taken hostage and died from multiple gunshot wounds inflicted by the DHKP/C after police attempted to rescue him. In August 2015, two women opened fire on the U.S. Consulate in Istanbul; one woman was identified as a member of the DHKP/C.

On January 20, 2017, a DHKP/C militant launched an anti-tank missile into Istanbul police headquarters. The attack did not result in any deaths or injuries.

In November 2018, a court in Istanbul issued an arrest warrant for members of the DHKP/C who were believed to be in Europe and connected with the 2015 death of Turkish prosecutor Mehmet Selim Kiraz.

In May 2019, two individuals linked to the DHKP/C were arrested by Turkish security forces, after entering the Turkish Parliament and taking a staff member hostage.

Strength: The DHKP/C is estimated to have several dozen members inside Turkey, with a support network throughout Europe.

Location/Area of Operation: Turkey and Europe

Funding and External Aid: The DHKP/C finances its activities chiefly through donations and extortion. The group raises funds primarily in Europe.

\section{REVOLUTIONARY STRUGGLE}

\section{Aka Epanastatikos Aghonas}

Description: Designated as an FTO on May 18, 2009, Revolutionary Struggle (RS) is a radical Marxist extremist group that has conducted attacks against both Greek and U.S. targets in Greece. RS emerged in 2003 following the arrests of members of two other Greek Marxist groups, 17 November and Revolutionary People's Struggle.

Activities: RS first gained notoriety when it claimed responsibility for the September 5, 2003, bombings at the Athens Courthouse during the trials of 17 November members. From 2004 to 2006, RS carried out IED attacks that included a March 2004 attack outside a Citibank office in Athens. RS claimed responsibility for the January 2007 rocket-propelled grenade attack on the 
U.S. Embassy in Athens, which damaged the building, and the March 2009 bombing of a Citibank branch in Athens.

The Greek government has made significant strides in curtailing the group's terrorist activity. On April 10, 2010, Greek police arrested six suspected RS members, including purported leader Nikos Maziotis, who later escaped. On April 3, 2013, five RS members were convicted by an Athens appeals court, three of them receiving maximum prison sentences. Maziotis and another accused RS conspirator, Paula Roupa, were convicted in absentia. Before Maziotis's recapture, RS conducted a bomb attack outside a Bank of Greece office in Athens in April 2014; the blast caused extensive damage to surrounding structures but no casualties.

In March 2016, a Greek court sentenced Maziotis to life in prison plus 129 years. In January 2017, Roupa was arrested by Greek police in Athens, later sentenced to life and 25 years' imprisonment. RS did not claim responsibility for any attacks in 2019.

Strength: Precise numbers are unknown.

\section{Location/Area of Operation: Greece}

Funding and External Aid: RS's sources of funding are unknown, but the group most likely supports itself by means of criminal activities, including bank robbery.

\section{AL-SHABAAB}

Aka Harakat Shabaab al-Mujahidin; al-Shabab; Shabaab; Youth Wing; Mujahidin al-Shabaab Movement; Mujahideen Youth Movement; Mujahidin Youth Movement; al-Hijra, al Hijra, Muslim Youth Center, MYC, Pumwani Muslim Youth, Pumwani Islamist Muslim Youth Center; Hizbul Shabaab; Hisb'ul Shabaab; al-Shabaab al-Islamiya; al-Shabaab al-Islaam; al-Shabaab alJihad; The Unity of Islamic Youth; Harakat al-Shabaab al-Mujaahidiin; Harakatul-Shabaab al Mujaahidiin; Mujaahidiin Youth Movement

Description: Al-Shabaab was designated as an FTO on March 18, 2008. Al-Shabaab was the militant wing of the former Somali Islamic Courts Council that took over parts of southern Somalia during the second half of 2006. Since the end of 2006, al-Shabaab and associated militias have engaged in violent insurgency using guerrilla warfare and terrorist tactics against the transitional governments of Somalia.

Al-Shabaab is an official al-Qa'ida (AQ) affiliate and has ties to other AQ affiliates, including alQa'ida in the Arabian Peninsula and al-Qa'ida in the Islamic Maghreb. The group's leader is Ahmed Diriye aka Ahmed Umar aka Abu Ubaidah.

Al-Shabaab is composed of Somali recruits and foreign terrorist fighters. Since 2011, alShabaab has seen its military capacity reduced owing to the efforts of the African Union Mission in Somalia (AMISOM) and Somali forces, and clashes within the group itself. Despite alShabaab's loss of urban centers since 2012, the group has maintained its hold on large sections of rural areas throughout Somalia and has conducted attacks in Somalia, Kenya, Uganda, and Djibouti.

Activities: Al-Shabaab has used intimidation and violence to exploit divisions in Somalia and undermine the Somali government, recruit new fighters, extort funding from local populations, and kill activists working to bring about peace through political dialogue. The group has claimed 
responsibility for several high-profile bombings and shootings throughout Somalia targeting AMISOM troops and Somali officials. Al-Shabaab has assassinated numerous civil society figures, government officials, journalists, international aid workers, and members of nongovernmental organizations.

Al-Shabaab was responsible for the July 11, 2010, suicide bombings in Kampala, Uganda - its first attack outside of Somalia. The attack, which took place during the World Cup, killed 76 people, including a U.S. citizen. In September 2013, al-Shabaab staged a significant attack against the Westgate Mall in Nairobi, Kenya. The multi-day siege resulted in the deaths of at least 65 civilians, including foreign nationals from 13 countries as well as six soldiers and police officers; hundreds of others were injured. In April 2015, al-Shabaab carried out a raid with small arms and grenades on Kenya's Garissa University College that killed 148 people.

Al-Shabaab claimed responsibility for one of the deadliest attacks against AMISOM troops in Somalia in January 2016. Using a VBIED and small arms fire, al-Shabaab massed against a Kenyan AMISOM base and killed more than 100 soldiers. In February, al-Shabaab attempted to down Daallo Airlines Flight 321 with 74 passengers on board, but only the suicide bomber was killed in the explosion.

Al-Shabaab continued a steady pace of attacks in 2017, including in car bomb attacks in Mogadishu in January, March, and June that killed more than 70 people. In October 2017, it is believed that al-Shabaab conducted a double truck bombing in a Mogadishu intersection with heavy vehicle and pedestrian traffic that killed more than 500 people and injured 300 others.

In July 2018, al-Shabaab claimed responsibility for an attack on Somalia's interior ministry compound, killing at least nine people. In November 2018, al-Shabaab claimed responsibility for an attack in which suicide attackers set off two car bombs at a hotel near the headquarters of Somalia’s Criminal Investigations Department in Mogadishu, killing at least 17 people.

In 2019, al-Shabaab was involved in more than 1,000 violent events in Somalia and eastern Kenya. In January, al-Shabaab claimed responsibility for a hotel attack in Kenya that killed 21 people and injured 28 others. In March, al-Shabaab claimed responsibility for an attack on the government ministries in Mogadishu, killing 15 people including a deputy minister and injuring 11 others. In July, al-Shabaab claimed responsibility for a suicide bombing at the office of Mogadishu mayor Abdirahman Omar Osman, killing eight people including Osman and injuring several others. In October, al-Shabaab conducted an attack on the UN and AMISOM compound in Mogadishu, killing seven people and wounding others. In December, al-Shabaab claimed responsibility for an attack on a passenger bus in northeastern Kenya that killed eight people, including Kenyan police officers, and injured others. Later that month, al-Shabaab claimed responsibility for a bomb blast in Mogadishu that killed more than 90 people.

Strength: Al-Shabaab is estimated to have between 7,000 and 9,000 members.

Location/Area of Operation Somalia, Kenya, and Uganda

Funding and External Aid: Al-Shabaab receives enough income to launch attacks throughout Somalia, including against AMISOM bases and other civilian targets. Al-Shabaab obtains funds through illegal charcoal production and exports, taxation of local populations and businesses, and by means of remittances and other money transfers from the Somali diaspora (although these funds are not always intended to support al-Shabaab members). 


\section{SHINING PATH}

Aka SL; Sendero Luminoso; Ejército Guerrillero Popular; EGP; Ejército Popular de Liberación; EPL; Partido Comunista del Peru (Communist Party of Peru); PCP; Partido Comunista del Peru en el Sendero Luminoso de Jose Carlos Mariategui (Communist Party of Peru on the Shining Path of Jose Carlos Mariategui); Socorro Popular del Peru; SPP, Communist Party of Peru on the Shining Path of Jose Carlos Mariategui, Communist Party of Peru, People's Aid of Peru, People's Guerrilla Army; People's Liberation Army

Description: The Shining Path (Sendero Luminoso or SL) was designated as an FTO on October 8, 1997. The Peru-based terrorist organization was formed in the late 1960s by former university professor Abimael Guzman, whose teachings created the foundation of SL's militant Maoist doctrine. In the 1980s, SL was one of the most ruthless terrorist groups in the Western Hemisphere. In 1992, the Peruvian government captured Guzman who, along with key accomplices, is serving a life sentence in prison. SL is now led by brothers Victor and Jorge Quispe Palomino and Tarcela Loya Vilchez. Under their direction, the group aims to overthrow the Peruvian government and names the United States as a principal enemy.

Activities: SL attacks have declined in recent years. On April 9, 2016, the group attacked a sixvehicle military caravan transporting election materials ahead of the country's election; eight soldiers and two civilian contractors were killed by SL members armed with long-range rifles and grenades. In separate incidents in 2017, SL killed several policemen in an area where the group controls territory and facilitates drug trafficking.

In June 2018, six soldiers were wounded by SL sharpshooters at the Nueva Libertad military base. In the same month, a group of SL members killed five soldiers and wounded another in an attack on the Nueva Libertad military base in the region of Junín, and attacked a police vehicle using a roadside bomb, killing four policemen.

In June 2019, suspected SL members conducted an attack on the Peruvian Army, killing three soldiers.

Strength: Estimates of SL's strength vary, but experts assess SL to number between 250 and 300 combatants.

\section{Location/Area of Operation: Peru}

Funding and External Aid: SL is primarily funded by the illicit narcotics trade.

\section{TEHRIK-E TALIBAN PAKISTAN}

Aka Pakistani Taliban; Tehreek-e-Taliban; Tehrik-e-Taliban; Tehrik-i-Taliban Pakistan; TTP

Description: Designated as an FTO on September 1, 2010, Tehrik-e Taliban Pakistan (TTP) is a Pakistan and Afghanistan-based terrorist organization formed in 2007 to oppose Pakistani military efforts in Khyber Pakhtunkhwa province (formerly known as the Federally Administered Tribal Areas). Previously disparate tribal militants agreed to cooperate and eventually coalesced into TTP under the leadership of now-deceased leader Baitullah Mehsud. Mullah Fazlullah headed the group until his death in June 2018. TTP then named Mufti Noor Wali Mehsud as the group's new leader. 
TTP aims to push the Government of Pakistan out of Khyber Pakhtunkwa province and establish Sharia law by waging a terrorist campaign against the Pakistani military and state. TTP uses the tribal belt along the Afghanistan-Pakistan border to train and deploy its operatives, and the group has ties to al-Qa'ida (AQ). TTP draws ideological guidance from AQ, while elements of AQ rely in part on TTP for safe haven in the Pashtun areas along the Afghanistan-Pakistani border. This arrangement has given TTP access to both AQ's global terrorist network and its members' operational expertise.

Activities: TTP has carried out and claimed responsibility for numerous terrorist acts against Pakistani and U.S. interests, including a December 2009 suicide attack on a U.S. military base in Khost, Afghanistan, which killed seven U.S. citizens; and an April 2010 suicide bombing against the U.S. Consulate in Peshawar, Pakistan, which killed six Pakistani citizens. TTP is suspected of involvement in the 2007 assassination of former Pakistani Prime Minister Benazir Bhutto. TTP directed and facilitated Faisal Shahzad's failed attempt to detonate an explosive device in New York City's Times Square on May 1, 2010.

Between 2011 and 2018, TTP continued to carry out attacks against the Government of Pakistan and Pakistani civilian targets, as well as against U.S. targets in Pakistan. In 2012, TTP carried out attacks against a mosque, a police checkpoint, a Pakistani Air Force base, and a bus carrying Shia Muslims. In 2013, TTP attacked churches, the home of a government minister in KhyberPakhtunkhwa province, and a Shia neighborhood in Karachi, Pakistan. These attacks killed and wounded hundreds of civilians and Pakistani government and law enforcement officials. In 2014, TTP carried out two consecutive attacks against Karachi's international airport and a siege on a primary school in Peshawar, Pakistan that killed 145 people, 132 of whom were children. In 2015, TTP bombed a Shia mosque near Peshawar and conducted suicide bombings at two churches in Lahore. In 2016, the group claimed responsibility for a December attack that left the Deputy Superintendent of the police counterterrorism department dead and his son injured in an attack on their vehicle in Peshawar.

TTP attacks in 2017 included several suicide bombings, among them a February attack that targeted a protest in Lahore, a March attack on a mosque in northwestern Pakistan, and a July attack in Lahore that killed 26 people. In December 2017, TTP militants disguised as women stormed an agricultural training school in Peshawar, leaving nine dead including the attackers.

In February 2018, TTP claimed responsibility for a suicide bombing that killed more than 11 Pakistani security personnel in Swat, Pakistan. TTP also claimed responsibility for a March 2018 suicide bombing that targeted a checkpoint on the outskirts of Lahore, resulting in the deaths of four police officers and two civilians.

TTP claimed multiple attacks in Pakistan in 2019. In July, TTP claimed responsibility for killing six soldiers on patrol in North Waziristan. TTP also claimed responsibility in August for killing four members of a 'peace committee' who were working with the Pakistani government in its efforts against the Afghan Taliban.

Strength: TTP is estimated to have between 3,000 and 5,000 fighters.

Location/Area of Operation: Pakistan and Afghanistan

Funding and External Aid: TTP likely raises most of its funds through kidnapping-for-ransom payments, extortion, and other criminal activity. 


\section{Chapter 6: Legislative Requirements and Key Terms}

Country Reports on Terrorism 2019 is submitted in compliance with Title 22 of the United States Code, Section 2656f (the "Act"), which requires the Department of State to provide Congress a full and complete annual report on terrorism for those countries and groups meeting the criteria of the Act. Statutory excerpts relating to the terms used in this report and a discussion of the interpretation and application of those terms in this report are included below.

\section{Excerpts and Summary of Key Statutory Terms.}

Section 2656f(a) of Title 22 of the United States Code states as follows:

(a) ... The Secretary of State shall transmit to the Speaker of the House of Representatives and the Committee on Foreign Relations of the Senate, by April 30 of each year, a full and complete report providing -

(1) (A) detailed assessments with respect to each foreign country -

(i) in which acts of international terrorism occurred which were, in the opinion of the Secretary, of major significance;

(ii) about which the Congress was notified during the preceding five years pursuant to section 4605(j) of Title 50 [deemed under Section 1768(c)(2) of the National Defense Authorization Act of Fiscal Year 2019 (NDAA FY19) to refer to section 1754(c) of the NDAA FY19 as of August 13, 2018]; and

(iii) which the Secretary determines should be the subject of such report; and

(B) detailed assessments with respect to each foreign country whose territory is being used as a sanctuary for terrorist organizations;

(2) all relevant information about the activities during the preceding year of any terrorist group, and any umbrella group under which such terrorist group falls, known to be responsible for the kidnapping or death of an American citizen during the preceding five years, any terrorist group known to have obtained or developed, or to have attempted to obtain or develop, weapons of mass destruction, any terrorist group known to be financed by countries about which Congress was notified during the preceding year pursuant to section 4605(j) of Title 50, any group designated by the Secretary as a foreign terrorist organization under section 219 of the Immigration and Nationality Act (8 U.S.C. 1189), and any other known international terrorist group which the Secretary determines should be the subject of such report;

(3) with respect to each foreign country from which the United States Government has sought cooperation during the previous five years in the investigation or prosecution of an act of international terrorism against United States citizens or interests, information on - 
(A) the extent to which the government of the foreign country is cooperating with the United States Government in apprehending, convicting, and punishing the individual or individuals responsible for the act; and

(B) the extent to which the government of the foreign country is cooperating in preventing further acts of terrorism against United States citizens in the foreign country; and

(4) with respect to each foreign country from which the United States Government has sought cooperation during the previous five years in the prevention of an act of international terrorism against such citizens or interests, the information described in paragraph (3)(B).

Section 2656f(d) of Title 22 of the United States Code defines certain key terms used in Section 2656f(a) as follows:

(1) The term "international terrorism" means terrorism involving citizens or the territory of more than one country;

(2) The term "terrorism" means premeditated, politically motivated violence perpetrated against non-combatant targets by subnational groups or clandestine agents; and

(3) The term "terrorist group" means any group practicing, or which has significant subgroups which practice, international terrorism.

Interpretation and Application of Key Terms. For purposes of this report, the terms "international terrorism," "terrorism," and "terrorist group" have the definitions assigned to them in 22 USC 2656f(d) (see above). The term "non-combatant," which is referred to but not defined in 22 USC $2656 f(d)(2)$, is interpreted to mean, in addition to civilians, military personnel (whether or not armed or on duty) who are not deployed in a war zone or a war-like setting.

It should be noted that 22 USC $2656 f(d)$ is one of many U.S. statutes and international legal instruments that concern terrorism and acts of violence, many of which use definitions for terrorism and related terms that are different from those used in this report. The interpretation and application of defined and related terms concerning terrorism in this report are therefore specific to the statutory and other requirements of the report, and not intended to express the views of the U.S. government on how these terms should be interpreted or applied for any other purpose. Accordingly, there is not necessarily any correlation between the interpretation of terms such as "non-combatant" for purposes of this report and the meanings ascribed to similar terms pursuant to the law of war (which encapsulates the obligations of states and individuals with respect to their activities in situations of armed conflict).

Statistical Information. Pursuant to 22 USC $\S 2656 \mathrm{f}(\mathrm{b})$, this report should contain "to the extent practicable, complete statistical information on the number of individuals, including United States citizens and dual nationals, killed, injured, or kidnapped by each terrorist group during the preceding calendar year." This is satisfied through the inclusion of a statistical annex to the report that sets out statistical information provided by Development Services Group, Inc. (DSG). The statistical annex includes a discussion of the methodology employed by DSG in 
compiling the relevant data. This report does not contain statistical information specifically concerning combatants. The focus of the terrorism report, as is clear from the definition of terrorism, is on violence against noncombatant targets.

Contextual Reporting. Adverse mention in this report of individual members of any political, social, ethnic, religious, or national population is not meant to imply that all members of that population are terrorists. Indeed, terrorists rarely represent anything other than a tiny fraction of such larger populations. It is terrorist groups - and their actions - that are the focus of this report.

Furthermore, terrorist acts are part of a larger phenomenon of violence inspired by a cause, and at times the line between the two can become difficult to draw. This report includes some discretionary information in an effort to relate terrorist events to the larger context in which they occur, and to give a feel for the conflicts that spawn violence.

Thus, this report will discuss terrorist acts as well as other violent incidents that are not necessarily "international terrorism" and therefore are not subject to the statutory reporting requirement. 